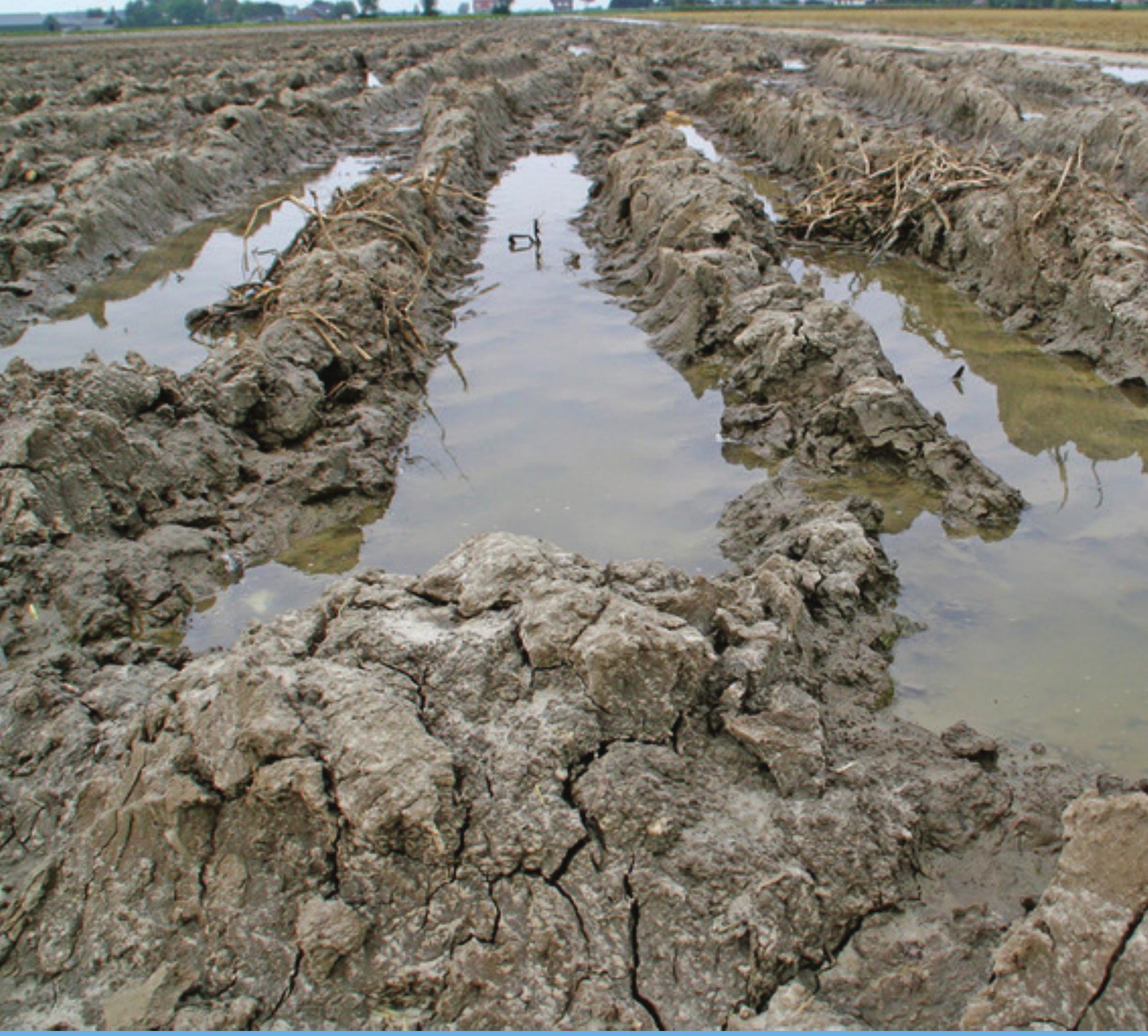

\title{
Hydrofysische gegevens van de bodem in BRO en BIS
}

Update 2017

G. Bakker, M. Heinen, W.J.M. de Groot, F.B.T. Assinck, H.P.A. Gooren, E.W.J. Hummelink

WAGENINGEN

UNIVERSITY \& RESEARCH 



\section{Hydrofysische gegevens van de bodem in BRO en BIS}

Update 2017

G. Bakker, M. Heinen, W.J.M. de Groot, F.B.T. Assinck, H.P.A. Gooren, E.W.J. Hummelink

Dit onderzoek is uitgevoerd door Wageningen Environmental Research in opdracht van en gefinancierd door het ministerie van Economische Zaken, in het kader van het Beleidsondersteunend onderzoekthema 'BIS'

(projectnummer BO-11-017-026).

Wageningen Environmental Research

Wageningen, juni 2018

Rapport 2895

ISSN 1566-7197 
Bakker, G., M. Heinen, W.J.M. de Groot, F.B.T. Assinck, H.P.A. Gooren, E.W.J. Hummelink, 2018. Hydrofysische gegevens van de bodem in BRO en BIS; Update 2017. Wageningen, Wageningen Environmental Research, Rapport 2895. 96 blz.; 8 fig.; 4 tab.; 53 ref.

Hydrofysische gegevens van de bodem, ofwel bodemgegevens die een sterke relatie hebben met het gedrag van water in de bodem, zijn belangrijke basisgegevens bij het modelleren van transport van water en opgeloste stoffen in de onverzadigde zone, maar zijn ook belangrijk in tal van andere toepassingen. Voorbeelden van hydrofysische bodemgegevens zijn met name de waterretentie- en doorlatendheidskarakteristiek, maar ook het organische stofgehalte, textuurgegevens, profielbeschrijving en andere metagegevens. Omdat er grote behoefte is aan actuele gegevens van hoge kwaliteit en omdat de huidige databases nog onvoldoende opschalingsmogelijkheden bieden, worden in dit project aanvullende kwalitatief hoogwaardige gegevens gegenereerd. De hydrofysische gegevens van de bodem en de bijbehorende beschrijvende gegevens zijn ondergebracht in het BIS (Bodem Informatie Systeem) en worden in de nabije toekomst ook ondergebracht in de BRO. Momenteel zijn er 181 monsters, gekoppeld aan profielbeschrijvingen en andere meta-informatie, in BIS opgenomen.

Trefwoorden: bodemfysica, hydrofysisch, SHP, bodemfysisch, BIS, BRO, retentie, pF-curve, waterdoorlatendheid, dichtheid.

Dit rapport is gratis te downloaden van https://doi.org/10.18174/454344 of op www.wur.nl/environmental-research (ga naar 'Wageningen Environmental Research' in de grijze balk onderaan). Wageningen Environmental Research verstrekt geen gedrukte exemplaren van rapporten.

2018 Wageningen Environmental Research (instituut binnen de rechtspersoon Stichting Wageningen Research), Postbus 47, 6700 AA Wageningen, T 0317480700 ,

www.wur.nl/environmental-research. Wageningen Environmental Research is onderdeel van Wageningen University \& Research.

- Overname, verveelvoudiging of openbaarmaking van deze uitgave is toegestaan mits met duidelijke bronvermelding.

- Overname, verveelvoudiging of openbaarmaking is niet toegestaan voor commerciële doeleinden en/of geldelijk gewin.

- Overname, verveelvoudiging of openbaarmaking is niet toegestaan voor die gedeelten van deze uitgave waarvan duidelijk is dat de auteursrechten liggen bij derden en/of zijn voorbehouden.

Wageningen Environmental Research aanvaardt geen aansprakelijkheid voor eventuele schade voortvloeiend uit het gebruik van de resultaten van dit onderzoek of de toepassing van de adviezen.

Wageningen Environmental Research Rapport 2895 | ISSN 1566-7197

Foto omslag: www.akkerwijzer.nl 


\section{Inhoud}

Woord vooraf $\quad 5$

$\begin{array}{ll}\text { Samenvatting } & 7\end{array}$

1

Inleiding $\quad 9$

1.1 Nut en noodzaak van hydrofysische bodemgegevens 9

1.1.1 Hydrofysische gegevens van de bodem als basis 9

1.1.2 Gezonde bodems (Eng: healthy soils) 10

1.1.3 Beleidsmodellen en Operationele modellen 11

1.2 Geschiedenis en toekomst van hydrofysische bodemgegevens 11

$\begin{array}{ll}1.2 .1 & \text { Staringreeks }\end{array}$

$\begin{array}{ll}1.2 .2 \text { Priapus } & 12\end{array}$

1.2.3 Vooronderzoek hydrofysische bodemgegevens voor BIS-Nederland 13

1.2.4 De bredere context: BIS en DINO komen gezamenlijk in de BRO 14

1.2.5 INSPIRE - Infrastructure for Spatial Information in the European
Community

1.2.6 SOPHIE - Soil Program on Hydro-Physics via International Engagement 15

1.2.7 Innovatie in het verzamelen van bodemgegevens 16

$\begin{array}{lll}1.3 & \text { Impact van het project } & 16\end{array}$

1.3.1 Bijdrage aan de BRO-doelstellingen 16

1.3.2 Bijdrage aan 'Key Recommendations' van het UN Data Revolution rapport 17

1.3.3 Bijdrage aan Sustainable Development Goals 17

$\begin{array}{ll}1.4 & \text { Aanleiding en probleemstelling } \\ 1.5 & 18\end{array}$

1.5 Projectdoelstelling $\quad 19$

$\begin{array}{llr}1.6 & \text { Leeswijzer } & 19\end{array}$

$\begin{array}{ll}\text { Materialen en methoden } & \mathbf{2 0}\end{array}$

2.1 Gegevenskeuze, kwaliteit en presentatie $\quad 20$

2.1.1 Welke hydrofysische bodemgegevens in BIS $\quad 20$

$\begin{array}{ll}2.1 .2 \text { Kwaliteitscriteria } & 20\end{array}$

2.2 Selectiewijze monsterlocaties $\quad 22$

2.2.1 Latin Hypercube Sampling $\quad 22$

2.2.2 Selectiewijze bemonsteringslocaties $\quad 22$

$\begin{array}{lll}2.3 & \text { Bemonsteringswijze } & 23\end{array}$

2.4 Analysemethoden $\quad 23$

2.4.1 Textuur $\quad 23$

2.4.2 Gloeiverlies $\quad 25$

2.4.3 Retentie- en onverzadigde waterdoorlatendheidskarakteristiek $\quad 25$

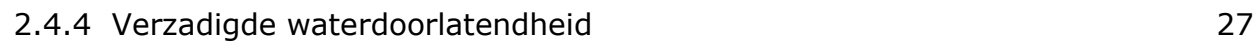

$\begin{array}{lll}2.5 & \text { Afgeleide gegevens } & 28\end{array}$

2.5.1 Ontwikkeling van Filter en Rekensheet in Excel 28

$\begin{array}{ll}2.5 .2 \text { Het MvG-concept: huidige werkwijze } & 29\end{array}$

2.5.3 Het PDI-concept: Uitbreiding op het MvG-concept 30

$\begin{array}{lll}3.1 & \text { Indeling detailresultaten } & 31\end{array}$

3.1.1 De 38 opschalingseenheden $\quad 32$

3.1.2 Belangrijkste Veldgegevens $\quad 32$

3.1.3 Belangrijkste hydrofysische bodemgegevens $\quad 32$

3.1.4 Aansluiting bij oudere Staringreeks 33

3.2 Aantallen monsters 33 
4.1 Rapport en database $\quad 35$

$\begin{array}{lll}4.2 & \text { Gebruiksadvies } & 35\end{array}$

4.2.1 Aandachtspunten $\quad 35$

4.2.2 Fuzzy-classificatie $\quad 36$

4.3 Raadplegen bodemfysische data in BIS $\quad 36$

5

$\begin{array}{ll}\text { Conclusies } & \mathbf{3 7}\end{array}$

$\begin{array}{ll}\text { Literatuur } & 39\end{array}$

Bijlage 1 Afhankelijke beleids- en operationele modellen 42

Bijlage 2 Excel-programma: Filter en Fit 44

Bijlage 3 De 38 Opschalingseenheden $\quad 50$

$\begin{array}{lll}\text { Bijlage } 4 & \text { Bodemkundige Basisgegevens } & 51\end{array}$

Bijlage 5 Afgeleide Bodemkundige Gegevens $\quad 55$

Bijlage 6 Belangrijkste Veldgegevens $\quad 59$

$\begin{array}{lll}\text { Bijlage } 7 & \text { Textuurgegevens } & 63\end{array}$

Bijlage 8 Gemeten dichtheden en Ksat, Staringbouwsteen en Gefitte $\begin{array}{ll}\text { MvG-parameters } & 67\end{array}$

$\begin{array}{lll}\text { Bijlage } 9 & \text { Grafieken waterretentie en -doorlatendheid } & 71\end{array}$

Bijlage 10 Bodemkundige Karakterisering: BoKa (Geo)-codes 91

Bijlage 11 Indeling Staringreeks $\quad 93$

Bijlage 12 Aantal BIS-monsters voor de 38 opschalingseenheden 94 


\section{Woord vooraf}

Dit onderzoek voor de verzameling van hydrofysische gegevens van de bodem voor het Bodem Informatie Systeem en de Bodem Registratie Ondergrond is onderdeel van het programma Bodem Informatie Systeem (BO-11, Natuur en Regio, thema 017). Het onderzoek is gefinancierd door het ministerie van Economische zaken. Wij zijn Frans Lips van dit ministerie erkentelijk voor zijn nuttige inbreng. Gegevens die binnen andere projecten worden verkregen en geschikt zijn voor opname in BIS en BRO worden eveneens in de database en deze rapportage opgenomen. Vanwege privacy overwegingen zijn alle gegevens geanonimiseerd en worden hier daarom niet bij naam genoemd. Desondanks zijn wij ook deze partijen zeer erkentelijk voor hun bijdragen.

Wageningen, april 2018 


\section{Samenvatting}

Hydrofysische parameters van de bodem zijn specifieke parameters binnen het domein van de bodemfysica. Met hydrofysische parameters worden die parameters bedoeld die een sterke relatie hebben met het gedrag van water in de bodem. Hydrofysische gegevens van de bodem zijn de belangrijkste fundamentele parameters die de bodem-water-interacties beschrijven:

- watertransport en waterretentie, en

- samen met watertransport, het transport van opgeloste stoffen zoals stikstof, fosfaat, pesticiden, antibiotica, organische verbinden, etc.

Het is daarom vanzelfsprekend dat deze, grondsoort afhankelijke, parameters als basisinformatie worden gebruikt bij een groot aantal onderzoeksdisciplines.

Het verzamelen en interpreteren van fundamentele gegevens over de bodem die een directe relatie hebben met de stroming en retentie van water en stoffen, de luchthuishouding en de invloed van organische stof op water in de bodem, is het domein van de bodemfysica, of specifieker, de hydrofysica van de bodem.

Het brede toepassingsgebied resulteert in grote behoefte aan actuele gegevens van hoge kwaliteit. Omdat de huidige databases nog onvoldoende opschalingsmogelijkheden bieden, worden in dit project elk jaar systematisch nieuwe, kwalitatief hoogwaardige gegevens toegevoegd aan BIS (Bodem Informatie Systeem). Vanwege het grote maatschappelijke belang, worden de hydrofysische bodemgegevens in de nabije toekomst ook aan de BRO (Bodem Registratie Ondergrond) toegevoegd. Hiervan is de minister van Infrastructuur en Milieu bronhouder.

Nieuwe gegevens, maar ook die uit oudere databases, waarvan de kwaliteit niet kan worden gegarandeerd, zijn niet in BIS/BRO opgenomen. De data in BIS 2017 bestaan daarom alleen uit gegevens met hoge kwaliteit:

1. 34 monsters van voor 1984 (nog te completeren reeks ${ }^{1}$ )

2. 10 monsters van voor 1984 (complete reeks, geen ruwe meetgegevens ${ }^{1}$ )

3. 10 monsters uit 2004 (complete reeks ${ }^{1}$ )

4. 137 gestoken monsters in de periode 2012-2017 (complete reeks ${ }^{1}$ )

5. 7 gestoken monsters in de periode 2012-2017 (incomplete reeks ${ }^{1}$ )

\section{Totaal: 198 monsters.}

Bovenop deze 198 kwaliteitsmonsters resteren nog

- 72 kwaliteitsmonsters van vóór 2012 waarvan geen profielbeschrijving in BIS aanwezig is. Ondanks dit hiaat, wordt de digitaal aanwezige informatie van deze 72 monsters van voldoende waarde geacht om in de nabije toekomst alsnog onder een 'dummy bodemprofiel' in BIS op te nemen. Overigens zijn van deze 72 monsters de bodemprofielen van 33 monsters via literatuur alsnog te achterhalen.

- Bovenop deze 72 monsters zijn er nog 19 kwaliteitsmonsters waarvan de digitale data onvoldoende informatie bevat voor BIS. Echter, de benodigde aanvullende gegevens zijn wel terug te vinden in de literatuur.

Het toevoegen van de aanvullende literatuurgegevens van de 33+19=52 monsters aan BIS kost onevenredig veel tijd. Daarom is besloten om de monsters weliswaar in BIS te gaan opnemen, maar daarbij een verwijzing naar de literatuur te geven: de literatuurdata zelf wordt voorlopig niet gedigitaliseerd. In plaats van het digitaliseren van oude data wordt de voorkeur gegeven aan het bemonsteren en analyseren van nieuwe locaties.

\footnotetext{
1 Hieronder wordt een toelichting gegeven van eventueel ontbrekende gegevens in incomplete reeksen.
} 
Ad 1:

Van 34 bestaande hoogwaardige monstergegevens van voor 1984 zijn de daarvan beschikbare digitale gegevens ondergebracht in BIS en zijn gekoppeld aan bestaande profielbeschrijvingen in BIS. Het betreft hier ten minste de afgeleide doorlatendheid-drukhoogte-vochtgehalte-relaties, maar nog geen textuur, organische stofgegevens en dichtheden; deze worden in 2018 gecompleteerd. Van deze monsters zijn geen ruwe meetgegevens meer aanwezig.

Ad 2:

Als 1), maar deze gegevens zijn al wel aangevuld met textuurgegevens, organische stofgegevens en dichtheden uit de literatuur. Voor deze monsters zijn de bodemfysische parameters van de Mualemvan Genuchten waterretentie- en doorlatenheidskarakteristieken opnieuw bepaald volgens de in dit rapport beschreven procedure.

Ad 3:

Nieuwe inzichten hebben in dit project geleid tot verbeterde software (2014), waarmee afgeleide gegevens betrouwbaarder dan voorheen bepaald kunnen worden. In 2016 is dit getest op meetgegevens van 10 monsters, waarvan de afgeleide gegevens oorspronkelijk in de oudere database Priapus als 'slecht' waren gekwalificeerd. De afgeleide gegevens van de opnieuw doorgerekende monsters voldoen alsnog aan de gestelde criteria en zijn samen met eventueel overige beschikbare meetgegevens en profielbeschrijvingen in BIS opgenomen.

Ad 4:

De complete reeksen van deze nieuwe monsters hebben uiteraard toegevoegde waarden ten opzichte van de oude incomplete reeksen, de kwaliteit is hoger, hebben meer opschalingsmogelijheden en zijn beter over Nederland verdeeld.

Ad 5:

Monsters die genomen zijn voor een ander project, en waarvoor met name de textuurdata ontbreekt.

Op basis van de huidige 198 monsters bevatten van de 38 opschalingseenheden (zie Bijlage 3: geologische afzetting, boven- of ondergrond, hoofdindeling en textuurindeling) nu 34 eenheden tenminste 3 monsters. Dit is de minimale vereiste waarde uitgaande van het feit dat vaak duplomonsters worden genomen. De streefwaarde van minimaal 2 monsterlocaties (> 3 monsters) per opschalingseenheid is daarmee gehaald, met uitzondering van de Organische eenheden 'venige klei $(1)^{\prime}$ ', 'zandig veen (0)' en 'venig zand (1)' en van de Niet-Eolische eenheden 'kleiarm silt (1)' en 'kleiig silt $(0)^{\prime}$.

Van de 36 Staringreeksbouwstenen zijn er

- 2 of meer monsters van 15 bovengronden en 15 ondergronden,

- 3 of meer monsters van 11 bovengronden en 14 ondergronden,

- 5 of meer monsters van 8 bovengronden en 11 ondergronden.

In de nabije toekomst worden met name de nog ontbrekende opschalingseenheden en Staringreeksbouwstenen opgevuld. Daarna worden de aantallen per eenheid aangevuld tot tenminste 10 locaties per eenheid, zodat inzicht wordt verkregen in de spreiding tussen de eenheden, en het opschalen of clusteren van resultaten beter mogelijk wordt. Ook daarna is het nodig om de data te blijven vernieuwen, omdat bodems in de tijd aan (meestal langzame) veranderingen onderhevig zijn. 


\section{$1 \quad$ Inleiding}

Hydrofysische parameters van de bodem zijn specifieke parameters binnen het domein van de bodemfysica. Met hydrofysische parameters worden die parameters bedoeld die een sterke relatie hebben met het gedrag van water in de bodem. Hydrofysische parameters van de bodem zijn de belangrijkste fundamentele parameters die de bodem-water-interacties beschrijven:

- watertransport en waterretentie, en

- samen met watertransport, het transport van opgeloste stoffen zoals stikstof, fosfaat, pesticiden, antibiotica, organische verbinden, etc.

Het is daarom vanzelfsprekend dat deze, grondsoort afhankelijke, parameters als basisinformatie worden gebruikt bij een groot aantal onderzoeksdisciplines.

Het verzamelen en interpreteren van fundamentele gegevens over de bodem die een directe relatie hebben met de stroming en retentie van water en stoffen, de luchthuishouding en de beschikbaarheid van organische stof, is het domein van de bodemfysica of, specifieker, hydrofysica van de bodem.

Het brede toepassingsgebied resulteert in grote behoefte aan actuele gegevens van hoge kwaliteit. Omdat de huidige databases nog onvoldoende opschalingsmogelijkheden bieden, worden in dit project elk jaar systematisch kwalitatief hoogwaardige gegevens toegevoegd aan BIS (Bodem Informatie Systeem). Vanwege het grote maatschappelijke belang, worden de hydrofysische gegevens van de bodem in de nabije toekomst ook aan de BRO (Bodem Registratie Ondergrond) toegevoegd. Hiervan is de minister van Infrastructuur en Milieu bronhouder.

Nieuwe gegevens, maar ook die uit oudere databases, waarvan de kwaliteit niet kan worden gegarandeerd, zijn niet in BIS/BRO opgenomen. De gegevens set in BIS 2017 bestaat daarom alleen uit gegevens met hoge kwaliteit.

\subsection{Nut en noodzaak van hydrofysische bodemgegevens}

\subsubsection{Hydrofysische gegevens van de bodem als basis}

Overheden en diverse nationale en internationale organisaties maken zich steeds meer zorgen over bodemdegradatie en klimaatverandering als gevolg van de intensivering en veranderingen van landgebruik. De voedselvoorziening, biodiversiteit en natuurlijke ecosystemen worden beïnvloed en samenlevingen worden bedreigd. Het gevolg daarvan is dat er toenemende behoefte is aan inzichten, methoden en technieken om te komen tot 'duurzaam en gezond bodemgebruik'. De wetenschap die zich bezig houdt met de hydrofysica van de bodem speelt een grote rol bij maatschappelijke onderwerpen die te maken hebben met oogstopbrengsten, effecten van de bodemeigenschappen op klimaatverandering door broeikasgasemissies, uitspoeling en retentie van nutriënten en contaminanten, natuurwaarden, bodemverdichting, erosie, efficiëntie van watergebruik en de invloed van de bodem op de veiligheid van dijken. Voor het faciliteren van gedegen onderzoeken zijn landsdekkende gegevens nodig van goede kwaliteit. 


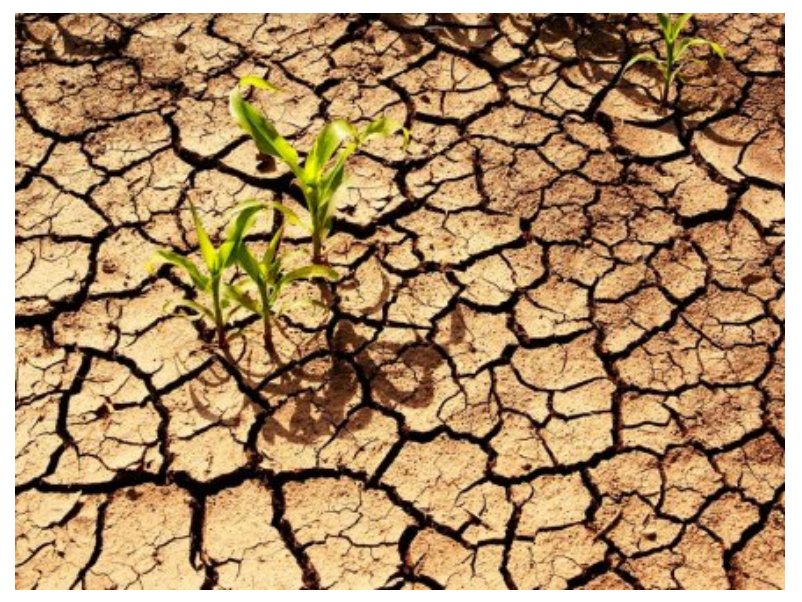

Figuur 1.1 Scheuren in een kleigrond door krimp beïnvloeden duidelijk de fysische eigenschappen. Er wordt gewerkt aan modellen die dit gedrag kunnen beschrijven. Daarom is data van goede kwaliteit nodig om hierin voortgang te kunnen boeken.

Voorbeelden van belangrijke hydrofysische gegevens van de bodem zijn het organische stofgehalte van de bodem, textuur, structuur, dichtheid, krimp- en zweleigenschappen van klei- en veengronden, waterafstotende eigenschappen in bijvoorbeeld dijken of na bosbranden, maar vooral ook de waterretentie- en doorlatendheidskarakteristieken, die direct gebruikt kunnen worden voor het modelleren van transport van water en opgeloste stoffen in de onverzadigde zone.

De bodem kent verschillende gebruiksvormen of gebruiksfuncties. Vaak zijn deze bodemfuncties bewust aan een bepaalde locatie gekoppeld, omdat de bodemeigenschappen daar geschikt zijn voor de functie. De dynamiek in het bodemvocht speelt daarin een cruciale rol. De bodem is een belangrijke parameter in de waterkringloop tussen atmosfeer, grondwater en rivieren. Grondwater, bodem en waterdamp zijn media die zich gedragen als paden waarlangs stoffen worden getransporteerd. De systemen zijn sterk gekoppeld met de uitwisseling van energie en warmte tussen het aardoppervlak en atmosfeer en zijn daarom belangrijk in weersvoorspellingen en voorspellingen van klimaatverandering op regionale en wereldschaal. De wisselwerking tussen fysische en biochemische processen, nutriënten, organische en toxische stoffen, (de)nitrificatie of de emissie of absorptie van broeikasgassen uit of in de grond komt ook tot uitdrukking in de in Nederland nog vrij onbekende term 'bodemgezondheid'. De term is echter sterk in opkomst en past in deze tijd van integrale benaderingen.

\subsubsection{Gezonde bodems (Eng: healthy soils)}

Bodemgezondheid wordt vaak geassocieerd met schone grond, ofwel met grond die geen verontreinigingen bevat, en aan de directe relatie met gezondheid van mens en dier. De term 'gezonde bodem' poogt echter vooral aan te duiden dat de bodem zelf gezond, ofwel van goede kwaliteit is, en dat is breder dan alleen een goede chemische gezondheid. Een gezonde bodem is in staat om duurzaam goed te functioneren, uiteindelijk resulterend in een gezonde leefomgeving voor mens en dier. Hoewel een dergelijke omschrijving van een gezonde bodem in Nederland nog weinig gebruikt wordt, is hij elders in de wereld al veel toegepast. De driehoek Fysisch-Chemisch-Biologisch omspant de eigenschappen van de bodem die bepalend zijn voor de bodemgezondheid. De hydrofysische gegevens van de BRO maken deel uit van de fysische bodemkwaliteit binnen de driehoek. De term is in het leven geroepen omdat de bodem nu te vaak vanuit eenzijdig perspectief wordt bezien. De bodem is echter een complex systeem dat een integrale benadering vraagt. Alleen met een integrale benadering kunnen grote vraagstukken die betrekking hebben op bijvoorbeeld voedselzekerheid en het verminderen van effecten van een veranderend klimaat, op een duurzame wijze worden opgelost. De bodemgezondheid wordt momenteel bedreigd door klimaatverandering, resulterend in bijvoorbeeld intensere regens en overvloedige erosie of, door verkeerd landgebruik, het uitmijnen van organische stof en essentiële nutriënten. Hierdoor staan ook de kwantiteit en de kwaliteit van de gewassen die verbouwd worden onder druk. 


\subsubsection{Beleidsmodellen en Operationele modellen}

Beleidseffecten worden meestal gekwantificeerd met behulp van rekenmodellen. De hydrofysische gegeven van de bodem, die als basisinvoer voor deze modellen nodig zijn, hebben grote invloed op de uitkomsten van de modellen. Het belang van een goede dataset wordt daarmee onderstreept.

Belangrijke beleidsmodellen die in Nederland bij omgevingsgericht onderzoek gebruikt worden zijn weergegeven in Bijlage 1. In deze bijlage zijn eveneens de diverse (experimentele) modellen weergegeven die worden gebruikt op projectbasis. Ook deze modellen zijn afhankelijk van de hydrofysische bodemgegevens als basis.
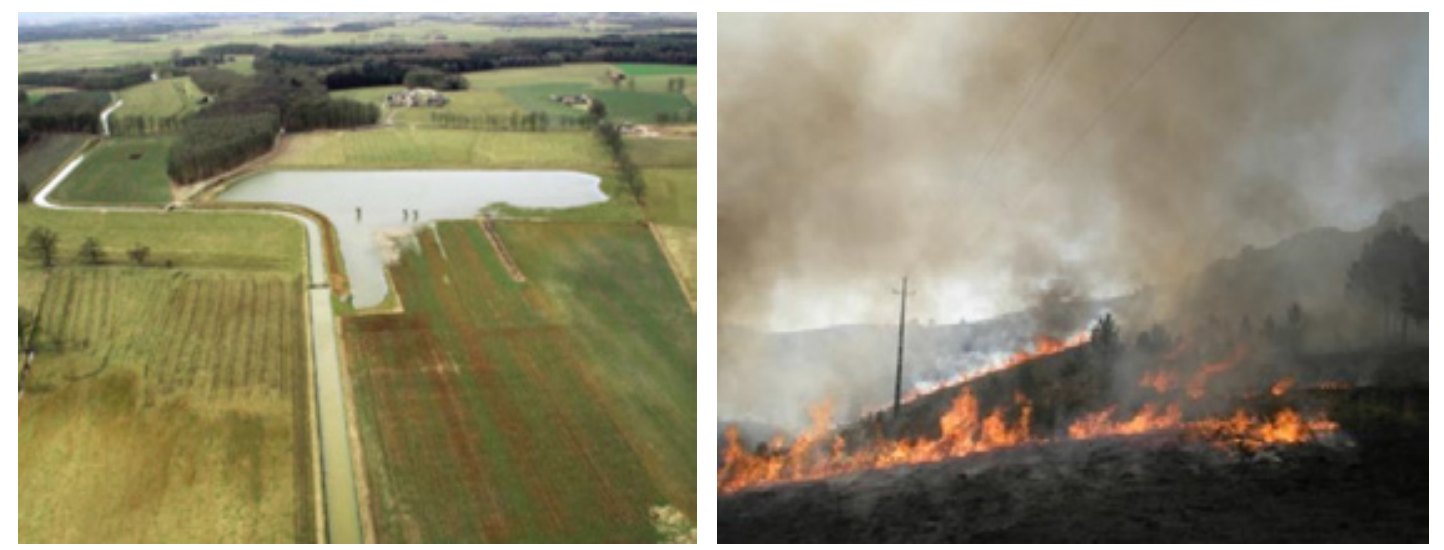

Figuur 1.2 Foto links: Proeflocatie in Salland - onderzoek naar de invloed van kortstondige inundatie van grasland op draagkracht, af- en uitspoeling van nutriënten en grasopbrengst. Foto rechts: Proeflocatie in Portugal - onderzoek naar de invloed van bosbranden op de relatie tussen hydrofysische bodemeigenschappen en erosie.

\subsection{Geschiedenis en toekomst van hydrofysische bodemgegevens}

Al sinds het ontstaan van de bodemfysische wetenschap kort na WOII is men bezig om hydrofysische gegevens van de bodem systematisch te rangschikken en is men op zoek naar mogelijke generalisaties. In Nederland heeft deze systematiek voor het eerst vorm gekregen in de Staringreeks. In de loop van de tijd zijn regelmatig aanvullingen uitgevoerd en updates uitgebracht:

- Staringreeks 1987 (Wösten et al., 1987)

- Staringreeks 1994 (Wösten et al., 1994)

- Staringreeks 2001 (Wösten et al., 2001)

- Priapus 2010 (Verzandvoort et al., 2012)

- Bodemfysische gegevens in BIS 2014 (Bakker et al., 2015)

- Bodemhydrofysische gegevens in BIS - Update 2016 (Bakker et al., 2017)

Hieronder wordt een beknopte geschiedenis van de hydrofysische bodemreeksen gegeven en de logische opvolgingen die vervolgens plaatsvonden. De laatste jaren wordt hard gewerkt om niet alleen hydrofysische gegevens van de bodem, maar ook veel andere gegevens over de bodem dusdanig te standaardiseren en te verzamelen dat zij onder te brengen zijn in BIS, maar ook in landelijke en vervolgens Europese databanken, zoals de Nederlandse BRO en het Europese INSPIRE. Het SOPHIEplatform probeert in een internationale setting richting te geven aan harmonisatie, standaardisatie en innovatie van hydrofysische veld- en laboratoriummetingen. 


\subsubsection{Staringreeks}

In 1987 is de Staringreeks voor het eerst uitgebracht aan de hand van 273 grondmonsters (Wösten et al., 1987). In 1994 en in 2001 heeft er een uitbreiding plaatsgevonden tot respectievelijk 620 en 832 monsters die ondergebracht zijn in 18 boven- en 18 ondergronden (Wösten et al., 1994, 2001).

Uitgangspunt bij de opzet van de Staringreeks was de Bodemkaart van Nederland (1: 50 000). De textuurklassen van de daarop aangegeven bodemhorizonten zijn op diverse plekken in Nederland bemonsterd in zowel de boven- als ondergrond (wortelzone en daaronder). Vervolgens is van elke onderscheiden 18 bovengronden en 18 ondergronden een gemiddelde waterretentie- en waterdoorlatendheidskarakteristiek bepaald. De Staringreeks bevat geen gegevens van afzonderlijke monsters, maar geeft gemiddelden van de karakteristieken. Om het gebruik in simulatiemodellen te vereenvoudigen, zijn de karakteristieken behalve in tabelvorm ook beschreven met 'klassevertaalfuncties'. Dit zijn analytische vergelijkingen die beschreven worden met de MualemVan Genuchten parameters (Mualem, 1976; Van Genuchten, 1980). Aanvullend zijn nog 'continue vertaalfuncties' (Eng.: pedotransfer functions) gegeven die de klasse-vertaalfuncties kunnen genereren op basis van lutumgehalte, leemgehalte, organische stofgehalte, M50, dichtheid en een boven- of ondergrondaanduiding.

Voor- en nadelen Staringreeks

Het grote voordeel van de Staringreeks is het overzichtelijke en snel toepasbare karakter. Dit heeft ervoor gezorgd dat het veel gebruikt wordt in modelstudies. Nadeel is echter dat de ruwe data en beschrijvende gegevens van de monsters onbekend zijn. Gebruikers van de Staringreeks hebben behoefte aan meer differentiatie van de HF-bodemgegevens en aan een hogere betrouwbaarheid van de gemiddelde karakteristieken per bouwsteen. Dit inzicht is van belang om de betrouwbaarheid van uitkomsten van modellen te kunnen kwantificeren. De indeling van de Staringreeks is gemaakt op basis van textuur, aard van het moedermateriaal (grove indeling) en het organische stofgehalte (grove indeling). Er wordt niet of nauwelijks onderscheid gemaakt in dichtheid, bodemtype en afzettingsmilieu. De pakking, sortering en het organische stofgehalte van oude dekzanden zijn bijvoorbeeld beduidend anders dan bij de stuifzandgronden. Als gevolg hiervan verwacht men ook dat de HF-bodemkarakteristieken verschillen. Hiermee is echter in de huidige Staringreeks geen rekening gehouden. De HF-bodemkarakteristieken zijn gemiddelden binnen dezelfde bouwsteen, waardoor het hydraulische gedrag van alle bodemhorizonten binnen een bouwsteen hetzelfde is.

\subsubsection{Priapus}

In opdracht van het Project Kwaliteitsslag Databestanden \& Modellen van het WOT-MNP en de Helpdesk Vitaal Landelijk Gebied heeft er, als gevolg van de veranderde gebruikerswensen, een kwaliteitsanalyse plaatsgevonden. Tussen 2006 en 2008 zijn afgeleide gegevens en beschrijvende gegevens van grondmonsters, waarop onder meer de Staringreeks is gebaseerd, opgezocht in de archieven van Stiboka, ICW, Staring Centrum en Alterra. De afgeleide HF-bodemdata zijn opgenomen in het Microsoft Access gegevensbestand Priapus (Verzandvoort et al., 2012), terwijl van de beschrijvende (veld)gegevens een referentie is gegeven in het rapport. De gegevens zijn getoetst aan strenge kwaliteitseisen. De database is niet ontworpen ter vervanging van de Staringreeks, maar als een uitbreiding daarvan.

Voor de certificering tot Kwaliteitsstatus A in 2008 werd een groot deel van de monstergegevens vervolgens afgeschermd voor gebruik, omdat op grond van de gehanteerde criteria afgeleide gegevens of soms ook metingen onvoldoende volledig of betrouwbaar werden geacht, of omdat onvoldoende beschrijvende (veld)informatie van de grondmonsters aanwezig was. Mede omdat de bodem continu aan verandering onderhevig is en een groot deel van de monsters in Priapus (en Staringreeks) ouder is dan 30 jaar, zijn op dit moment nog onvoldoende recente en gecertificeerde gegevens van hydrofysische bodemkarakteristieken beschikbaar om nieuwe bodemschematisaties zoals PAWN (Wösten et al., 1988) of BOFEK2012 (Wösten et al., 2013) af te kunnen afleiden of om landsdekkende of regionale studies uit te kunnen voeren met bijvoorbeeld STONE. 
Voor- en nadelen Priapus

De afgeleide analysereeksen zijn nu per monster in Priapus opgenomen en uitgebreid getest op kwaliteitskenmerken. Door het ontsluiten van kwalitatief hoogwaardige afgeleide data, gecombineerd met de mogelijkheid om deze hydrofysische data van de bodem te koppelen aan meta-informatie per monsterpunt, wordt tegemoetgekomen aan de gebruikerswensen ten aanzien van het kunnen kwantificeren van de betrouwbaarheid van uitkomsten van hydrologische modellen en de variatie tussen de karakteristieken van monsters met verwante eigenschappen. De Priapus-opzet maakt een bredere toepassing van de data mogelijk dan de Staringreeks, omdat op een veel kleiner detailniveau eigenschappen zijn te vergelijken. Bovendien kan de gebruiker zelf voortschrijdende inzichten gebruiken om bijvoorbeeld klasse-vertaalfuncties te genereren die betrekking hebben op het afzettingsmilieu. Afgeleide datasets hebben in Priapus alleen het kwaliteitskenmerk 'goed' of 'expert' als zij een voldoende bereik hebben en als de data consistent is met de overig verkregen informatie op het meetpunt. Daarom zijn er veel minder hoogwaardige datasets (135 stuks) beschikbaar dan in de Staringreeks, die de afgeleide gegevens gebaseerd heeft op 832 monsters. Hierdoor zijn geen landsdekkende onderzoeken met Priapus mogelijk. Een ander belangrijk nadeel is dat vaak alleen de afgeleide gegevens in Priapus zijn opgenomen en niet de meetreeksen zelf, waardoor voortschrijdende inzichten niet toe te passen zijn op de oorspronkelijke ruwe meetdata. Bovendien ontbreken vaak profielbeschrijvingen en aanvullende meetgegevens, zoals de verzadigde waterdoorlatendheid en het organische stofgehalte.

\subsubsection{Vooronderzoek hydrofysische bodemgegevens voor BIS-Nederland}

Vanwege het ontbreken van voldoende gecertificeerde hydrofysische gegevens van de bodem in Priapus is in de aanloop naar de update voor BIS onderzocht welke aanvulling minimaal nodig is (Knotters et al., 2011).

Verzandvoort et al. (2012) stellen een nieuwe indeling in HF-bodemeenheden voor. Die indeling moet voldoen aan onder meer de eis dat hydrofysische bodemkarakteristieken op meerdere niveaus, zowel bodemkundig als geologisch, kunnen worden ingedeeld en geselecteerd. De criteria op basis waarvan opschaling dan kan plaatsvinden, zijn:

- afzettingsmilieu (6 hoofdklassen);

- textuur (6 leemklassen, 5 mediaanklassen, 10 lutumklassen);

- boven- en ondergrond (2 klassen);

- gehalte aan organische stof ( 6 klassen voor minerale gronden en 3 klassen voor moerige gronden).

Het theoretisch aantal ruimtelijke opschalingseenheden is volgens Knotters et al. (2011) dan gelijk aan 2364. Dit aantal is te groot om uit elke eenheid een monster te nemen. Daarom wordt monstername volgens een Latin Hypercube-steekproef aanbevolen. In dat geval moet ervoor gezorgd worden dat in ieder geval alle bovengenoemde klassen $(6+6+5+10+2+6+3=38)$ vertegenwoordigd zijn met ten minste twee monsters per klasse. Meerdere monsters per klasse zijn nodig om de nauwkeurigheid van geschatte gemiddelden te kunnen kwantificeren. Rekening houdend met de al aanwezige monsters in Priapus, concludeerden Knotters et al. (2011) dat er nog ten minste 50 horizonten bemonsterd moesten worden, resulterend in een minimale steekproefomvang van 100. Aanbevolen werd de monsterlocaties gericht te selecteren met als doel de hiaten in Priapus op te vullen. De LatinHypercube werkwijze heeft het voordeel dat het de gebruiker in staat stelt zelf de grootte van de ruimtelijke opschaling te kiezen. Het nadeel van de werkwijze is dat opschalings- of aggregatiemethoden voor kleine gebieden of voor 'empty domains' niet eenvoudig zijn. Het gebruik van modellen is hierbij onvermijdelijk.

De nieuwe ruimtelijke indeling van WEnR sluit nauw aan op de geologische indeling die Deltares gebruikt voor de diepere ondergrond. Het is echter niet realistisch om een compatibiliteit van $100 \%$ te bereiken. De overeenkomsten zijn echter dusdanig groot dat dit een gunstige uitwerking heeft voor de samenvoeging van het Dinoloket en het BIS in de Basis Registratie Ondergrond. 


\subsubsection{De bredere context: BIS en DINO komen gezamenlijk in de BRO}

\section{BIS (Bodem Informatie Systeem van WEnR)}

Bodemgegevens staan in de top 5 van meest door de overheid gebruikte gegevens (Vries de, et al., 2017). Het betreft dan veelal bodemgegevens uit het Bodemkundig Informatie Systeem (BIS) dat in beheer is bij WENR. BIS-Nederland bevat, behalve hydrofysische meetdata én afgeleide gegevens, enorm veel informatie over de Nederlandse bodem die vanaf de jaren zestig tot op heden op systematische wijze is verzameld en bewerkt. BIS-Nederland bestaat uit de volgende onderdelen:

- Lokale bodemgegevens over de bodemkwaliteit, bodemopbouw en hydrofysische en chemische eigenschappen per laag;

- Landsdekkende bodem- en grondwatertrappenkaart schaal 1 : 50 000;

- Landsdekkende bodemkaart schaal 1 : 250 000;

- Bodem- en grondwatertrappenkaarten op schalen 1 : 25000 en 1 : 10 000;

- Kaarten en bestanden met gedetailleerde beschrijving van de grondwaterdynamiek;

- DeltaBIS: mogelijkheid tot vervaardiging van kaarten 'op recept' door de gebruiker zelf.

\section{DINO - Data en Informatie van de Nederlandse Ondergrond}

DINO staat voor Data en Informatie van de Nederlandse Ondergrond. Daar waar BIS zich richt op de Nederlandse bovengrond tot circa 1,2 m-mv, richt TNO zich met DINO op de bodem daaronder. DINO is de centrale opslagplaats voor geowetenschappelijke gegevens over de diepe en ondiepe ondergrond van Nederland (voor diverse gebruiksdoeleinden), die te maken hebben met grondwater, delfstoffen en bodemchemie. Vanaf 2006 zijn voor DINO ongeveer 200 boringen tot 30 à 40 meter diepte uitgevoerd met zeer zware apparatuur en zijn er circa 6000 analyses verricht (mondelinge informatie TNO, 2014). Het betreft steekboringen, waarin sonderingen en meestal een boorgatmeting zijn uitgevoerd. De zware apparatuur is ongeschikt voor het nemen van monsters ten behoeve van BIS vanwege de gevoeligheid van hydraulische kenmerken voor mechanische verstoringen. DINO en BIS bestrijken elk een eigen toepassingsgebied en zijn complementair.

\section{BRO - Basis Registratie Ondergrond}

BRO staat voor Basis Registratie Ondergrond. Binnen BRO wordt de ondergrond gedefinieerd als de ruimte tussen het maaiveld en de aardkern (Hooghart, 2011). BRO is een van de Geo-basisregistraties van het ministerie van Infrastructuur en Milieu. Het besluit tot invoering van BRO is in nauwe samenwerking met de overige bestuursorganen tot stand gekomen en zal ook gezamenlijk verder worden uitgewerkt tot een eenduidig, landelijk systeem.

In BRO wordt zowel BIS als DINO opgenomen, omdat beide afzonderlijke informatiesystemen onvoldoende met elkaar zijn verbonden en de gegevens vaak andere doelen dienen. Het gebruik van geologische en bodemkundige gegevens vindt veelal plaats in de vorm van kaarten en profielen die gebaseerd zijn op geologische en bodemkundige modellen. In BRO worden verder de diepe mijnbouwwet-gerelateerde gegevens opgenomen. Die worden momenteel verstrekt via NLOG (NL Olie-en Gasportaal).

BRO maakt onderdeel uit van het Stelsel van Basisregistraties. Met dit stelsel verbetert de overheid haar dienstverlening door belangrijke gegevens over onder andere personen, bedrijven, gebouwen en de ondergrond binnen de overheid te delen via de zogeheten 'webdiensten'. Dankzij goed gestructureerde formulieren en protocollen kunnen gebruikers gegevens opvragen of een berekening laten uitvoeren. Op dezelfde manier kunnen gebruikers binnenkort grondwaterstanden opvragen of een dwarsdoorsnede maken van een driedimensionaal ondergrondmodel. Ook kunnen bronhouders en adviesbureaus rechtstreeks een vraag stellen aan het loket. Al deze gegevens zijn kosteloos beschikbaar en toegankelijk voor overheden, bedrijven en burgers. Het wettelijke Stelsel kent 11 Basisregistraties, waaronder bijvoorbeeld Adressen en Gebouwen(BAG), Basisregistratie Grootschalige Topografie (BGT), Basisregistratie Kadaster (BRK), Bodem Registratie Ondergrond (BRO), Basisregistratie Personen (BRP), Basisregistratie Voertuigen (BRV), Waarde Onroerende Zaken (WOZ), en andere, waarvan de BRO ongeveer even groot is als de andere 10 samen. 


\section{Situatie 2017 en daarna:}

De BRO (Basisregistratie Ondergrond) bestaat uit 26 registratieobjecten, waarvan 5 bodemkundige registratieobjecten. In 2017 zijn daarin gerealiseerd de Boormonsterprofielen, Bodemkaart van Nederland en de Geomorfologische Kaart van Nederland. In de komende periode 2018/2019 worden hydrofysische bodemgegevens uit BIS overgenomen, evenals andere bodemmonsteranalyses, maar ook de Grondwaterdynamische Kaart van Nederland. Voor de eerder opgenomen registraties worden in die periode updates uitgevoerd.

Beleidsmakers beschikken met BRO over meer en betere gegevens, waardoor ze sneller en beter gefundeerde beslissingen kunnen nemen ten aanzien van een breed spectrum aan beleidsvragen. Zij krijgen met BRO direct toegang tot de gegevens die voor hen van belang zijn. Het belang van adequate informatie over de bodem en ondergrond neemt in de toekomst verder toe, ook in het kader van Europese regelgeving. De exacte inhoud (registratieobjecten) van BRO wordt in samenwerking met belanghebbenden vastgelegd in de Catalogus BRO. Daartoe moet op grond van het wetsvoorstel voor de start van de BRO in ieder geval één $A M v B$ en één ministeriële regeling worden vastgesteld (2017). In de AMvB worden de brondocumenten van registratieobjecten aangewezen die in BRO worden opgenomen.

BRO geeft tevens invulling aan (een deel van) verplichtingen die voortvloeien uit de Europese richtlijn INSPIRE (zie hieronder). Deze richtlijn verplicht lidstaten onder meer gegevens over de ondergrond via internet ter beschikking te stellen. Dit betekent dat er een wettelijke verplichting voor alle bestuursorganen komt om gegevens, die in de catalogus BRO genoemd worden, aan te leveren.

De minister van Infrastructuur en Milieu wordt bronhouder van de gegevens die op het moment van de inwerkingtreding van de wet op de BRO in BIS en DINO staan. Eventuele terugmeldingen op deze gegevens zijn daarmee een verantwoordelijkheid van de minister, ook in het geval deze gegevens in het verleden door een ander bestuursorgaan zijn aangeleverd. Conform de andere basisregistraties is het uitgangspunt dat BRO de best mogelijke gegevens bevat, maar geen $100 \%$ garantie geeft op de juistheid. Bestuursorganen kunnen dus worden aangesproken op hun zorgplicht. Indien bij de totstandkoming van de brondocumenten zorgvuldigheid is betracht, heeft het bestuursorgaan aan zijn verplichtingen voldaan en geldt er geen verdere aansprakelijkheid.

\subsubsection{INSPIRE - Infrastructure for Spatial Information in the European Community}

BRO is opgezet met als doel de informatiehuishouding ten aanzien van de Nederlandse ondergrond te verbeteren. Met BRO geeft Nederland ook invulling aan de Europese INSPIRE-eisen voor de thema's uit de Annex II Geology en de Annex III: Soil, Environmental monitoring facilities. De INSPIRE-richtlijn verplicht de Europese lidstaten geo-informatie over 34 thema's te voorzien van metadata, deze te harmoniseren en beschikbaar te stellen via het INSPIRE-portaal volgens leveringsvoorwaarden die het gebruik niet onnodig belemmeren. INSPIRE zorgt er zo voor dat geo-informatie van goede kwaliteit beschikbaar, vindbaar en bruikbaar is en dat de inhoud ervan, ook over de landsgrenzen heen, op elkaar is afgestemd. Hiervoor richten de lidstaten een netwerk in dat bestaat uit één Europees en meerdere nationale internetportalen en netwerkdiensten. Via dit INSPIRE-netwerk krijgen zowel overheden als burgers en bedrijven toegang tot de geo-informatie. INSPIRE is gestart in 2007 en zal naar verwachting in 2019 volledig operationeel zijn. Een Europees Ruimtelijke Data Infrastructuur helpt beleidsmakers bij het beantwoorden van grensoverschrijdende vraagstukken.

\subsubsection{SOPHIE - Soil Program on Hydro-Physics via International Engagement}

De omvangrijke toepasbaarheid van betrouwbare HF-bodemgegevens maakt dat de behoefte aan deze gegevens breed gedragen wordt door onderzoekers en adviseurs en in toenemende mate ook door beleidsmakers. Echter, gelijktijdig blijkt harmonisatie en de ontwikkeling van nieuwe kosteneffectieve technieken moeilijk te realiseren. Dit komt voornamelijk door de geringe directe zichtbaarheid van hydrofysische bodemdata in de maatschappelijke onderwerpen waarin ze worden gebruikt. Dit resulteert erin dat het verzamelen van hydrofysische gegevens van de bodem tijdrovend en dus kostbaar blijft, mede gezien de geringe investeringen in innovatie op dit gebied. 
SOPHIE werkt daarom aan de ontwikkeling van een internationaal netwerk om te komen tot standaardisatie van, harmonisatie van en innovatie tot kosteneffectieve hydrofysische bodemmetingen. SOPHIE streeft naar een algemeen geaccepteerde mate van harmonisatie en standaardisatie van bepalingen in het veld en laboratorium, en het beschikbaar komen van data die zijn gebaseerd op gestandaardiseerde en geharmoniseerde procedures en methoden, die gebruikt kunnen worden als basis voor EU bodem-gerelateerde onderzoek en beleid.

Er zijn namelijk wel degelijk kansen om de stagnerende ontwikkeling van technieken en harmonisatie te verbeteren, maar die vragen een breed gedragen draagvlak, aanpassing, validatie en standaardisatie. Eén voorbeeld is de aanpassing van huidige kennis op het gebied van remote sensing en proximal sensing tot voor onze doelstelling bruikbare technieken en methoden. Deze nieuwe technieken kunnen, in combinatie met moderne veld- en laboratoriumtechnieken, leiden tot kosteneffectieve methoden voor de bepaling van hydrofysische parameters van de bodem. Daarmee kunnen de huidige databases zoals BIS en het Europese LUCAS sneller worden uitgebreid en leiden tot betrouwbaardere grootschalige studies.

\subsubsection{Innovatie in het verzamelen van bodemgegevens}

WENR heeft een literatuurstudie uitgevoerd (Knotters et al., 2017) om te kunnen bepalen welke nieuwe snellere technieken inmiddels beschikbaar zijn voor het verzamelen van bodemgegevens. Daarbij zijn vooral de technieken interessant waarvan wetenschappelijk is aangetoond dat zij de hydrofysische en hydrologische bodemeigenschappen in kaart kunnen brengen. De 'traditionele' manier om deze gegevens in het veld en laboratorium te bepalen, onder andere door het nemen van ringmonsters, is arbeidsintensief. De resultaten van de literatuurstudie laten zien dat er interessante aanknopingspunten zijn om snellere, maar meestal minder nauwkeurige methoden, zoals Proximal Sensing of Remote Sensing, te gebruiken en deze te koppelen aan de nauwkeurige conventionele methoden. Momenteel wordt door WENR een validatiestudie uitgevoerd met een gammaspectrometer onder een drone, waarmee snel grote bodemoppervlakken in kaart kunnen worden gebracht. De gammaspectrometer meet de van nature aanwezige radioactieve straling van de bodemfracties in klei, silt en zand in de bovenste delen van de bodem, waarbij elke fractie zijn specifieke herkenbare autonome straling heeft. De meting geeft daarmee een schatting van de grove textuurverdeling, onderverdeeld in lutum-, silt- en zandfracties. Omdat de meting passief de natuurlijke bodemstraling meet, is deze veilig voor de gezondheid. De meetdiepte is normaal gesproken echter niet groter dan $30 \mathrm{~cm}$. Zodra de gammaspectrometer geschikt gemaakt wordt als sonderingssensor, kunnen ook de diepere bodemlagen in kaart worden gebracht. Door de grovere snelle metingen op een groot aantal locaties te koppelen aan de gedetailleerde laboratoriummetingen van een beperkt aantal locaties, kunnen data slim worden geïnterpoleerd.

\subsection{Impact van het project}

\subsubsection{Bijdrage aan de BRO-doelstellingen}

De hydrofysische gegevens van de bodem in BIS zijn nog niet officieel gekoppeld aan een of meerdere registratieobjecten van de BRO. Omdat binnen dit onderzoek tevens boorprofielen worden gemaakt, kunnen de meeste monsters worden gekoppeld aan het registratieobject boormonsterprofielen. De in dit project uitgebreid bepaalde gegevens, kunnen in de nabije toekomst in BRO opgenomen worden en vormen essentiële basisgegevens voor modellen die gebruikt worden bij het beantwoorden van belangrijke maatschappelijke vragen. Het zwaartepunt in het hydrofysische deelonderzoek ligt uiteraard op het bepalen van de hydrofysische basisgegevens van de diverse bodemhorizonten, waarmee modellen met een bodem-water-interacties worden gevoed. Tezamen met de andere data in BIS/BRO ontstaat een zeer waardevolle relatie tussen enerzijds de hydrofysische basisgegevens en anderzijds profielbeschrijvingen, grondwatergegevens, chemische samenstelling van de bodem, geomorfologische gegevens en datamodellen. 


\subsubsection{Bijdrage aan 'Key Recommendations' van het UN Data Revolution rapport}

Data en modellen zijn van levensbelang voor besluitvorming en leveren het ruwe materiaal voor af te leggen verantwoording. Zonder de juiste informatie is het ontwerpen, monitoren en evalueren van beleid een bijna onmogelijke opgave.

Zo begint het rapport 'A world that counts' van de UN Expert Advisory Group on a Data Revolution for Sustainable Development (Gonzalez-Morales et al., 2014). De adviesgroep doet een aantal aanbevelingen, 'key recommendations', die ervoor moeten zorgen dat het verzamelen, opslaan en verstrekken van data beter wordt afgestemd op de informatie die we nodig hebben om de vorderingen op weg naar de Sustainable Development Goals (SDG's) te monitoren.

De doelstellingen van BRO komen in grote lijnen overeen met de doelstellingen van de UN Expert Advisory Group (Tabel 1.1). Wel moet worden opgemerkt dat wat betreft de realisatie van de Landelijke Voorziening van BRO er nog onvoldoende wordt gekeken naar de aansluiting bij de internationale bodemwereld. De relatie met SDG's is geen ontwerpcriterium.

Tabel 1.1 Enkele 'Key Recommendations' vanuit Gonzalez-Morales et al., 2014 en de bijdrage daaraan vanuit het gehele project BIS/BRO.

\begin{tabular}{|c|c|c|}
\hline Key Recommendations & Bijdrage & Opmerkingen \\
\hline $\begin{array}{l}\text { Ontwikkelen van consensus betreffende } \\
\text { principes en standaarden }\end{array}$ & $\begin{array}{l}\text { BRO draagt bij aan een nationale data } \\
\text { exchange standaard voor } \\
\text { HF-bodemgegevens. }\end{array}$ & $\begin{array}{l}\text { Nog onvoldoende aansluiting bij } \\
\text { internationale data exchange } \\
\text { standaarden, zoals INSPIRE }\end{array}$ \\
\hline $\begin{array}{l}\text { Ontwikkelen van systemen die voor } \\
\text { iedereen toegankelijk zijn }\end{array}$ & $\begin{array}{l}\text { BRO realiseert een voor iedereen } \\
\text { toegankelijk systeem (de Landelijke } \\
\text { Voorziening BRO) }\end{array}$ & $\begin{array}{l}\text { Het enkel en alleen verstrekken van } \\
\text { xml-bestanden zoals voorgenomen, zal } \\
\text { het gebruik van de data in ernstige } \\
\text { mate in de weg staan. Mogelijk } \\
\text { aansluiting bij PDOK om alternatieve } \\
\text { uitlevering te realiseren }\end{array}$ \\
\hline $\begin{array}{l}\text { Voldoende middelen voor verbetering } \\
\text { van data, modellen en de } \\
\text { toegankelijkheid hiervan }\end{array}$ & $\begin{array}{l}\text { Het ministerie van EZ draagt bij aan } \\
\text { het realiseren van de Landelijke } \\
\text { Voorziening BRO en aan de actualisatie } \\
\text { van de daarbij horende data en } \\
\text { modellen }\end{array}$ & \\
\hline Leiderschap voor coördinatie & $\begin{array}{l}\text { BRO is leidend en toonaangevend wat } \\
\text { betreft aardwetenschappelijke en } \\
\text { bodemkundige data }\end{array}$ & $\begin{array}{l}\text { Er is voor de bodemkundige data nog } \\
\text { onvoldoende aansluiting gezocht bij de } \\
\text { internationale bodemwereld }\end{array}$ \\
\hline $\begin{array}{l}\text { Zorg voor quick wins in relatie tot de } \\
\text { SDG-data }\end{array}$ & Niet gerealiseerd & $\begin{array}{l}\text { De potentiële bijdrage is onderwerp van } \\
\text { studie }\end{array}$ \\
\hline
\end{tabular}

\subsubsection{Bijdrage aan Sustainable Development Goals}

Nederland heeft de ambitie en streeft ernaar om alle door de regeringsleiders van de lidstaten van de Verenigde Naties vastgestelde Duurzame Ontwikkelingsdoelen (SDG's) in 2030 te behalen (Ploumen, 2016). Hydrofysische (HF-) bodemgegevens zijn gerelateerd aan een aantal van deze SDG's. Elke SDG kent een aantal indicatoren (E/CN, 2016). De via dit project in BIS/BRO opgeslagen gegevens en modellen hebben in een aantal gevallen een relatie met die indicatoren. Voor de HF-bodemgegevens zijn deze in Tabel 1.2 weergegeven. 
Tabel 1.2 Enkele SDG's en indicatoren (E/CN, 2016), en de bijdrage die HF-bodemgegevens daaraan leveren.

\begin{tabular}{|c|c|c|c|}
\hline SDG & Indicator & Bijdrage & Opmerking \\
\hline $\begin{array}{l}2 . \\
\text { Geen honger, bereik } \\
\text { voedselzekerheid en } \\
\text { duurzame landbouw }\end{array}$ & $\begin{array}{l}2.4 .1 \\
\text { Percentage duurzame } \\
\text { landbouw (landbouw gericht } \\
\text { op het behoud van } \\
\text { ecosystemen, op } \\
\text { klimaatbestendigheid en op } \\
\text { een voortdurende } \\
\text { verbetering van land- en } \\
\text { bodemkwaliteit }\end{array}$ & $\begin{array}{l}\text { HF-bodemgegevens dragen } \\
\text { fundamenteel bij aan het } \\
\text { begrip en het in kaart } \\
\text { brengen van de bodem ten } \\
\text { behoeve van optimalisatie en } \\
\text { verduurzaming van onder } \\
\text { andere de agrarische sector }\end{array}$ & \\
\hline $\begin{array}{l}6 . \\
\text { Schoon water en sanitair }\end{array}$ & $\begin{array}{l}6.1 .1 \\
\text { Percentage onbedreigde } \\
\text { watervoorraad } \\
6.4 \\
\text { Watergebruik efficiëntie } \\
6.6 \\
\text { Bescherming water- } \\
\text { gerelateerde ecosystemen }\end{array}$ & $\begin{array}{l}\text { HF-bodemgegevens worden } \\
\text { gebruikt bij het doorrekenen } \\
\text { van uitspoeling van } \\
\text { nutriënten en } \\
\text { verontreinigingen naar het } \\
\text { grond- en oppervlaktewater, } \\
\text { voor het optimaliseren van } \\
\text { irrigatiegiften en sturing op } \\
\text { ecosysteembehoud }\end{array}$ & \\
\hline $\begin{array}{l}13 . \\
\text { Klimaatactie }\end{array}$ & $\begin{array}{l}13.2 .1 \\
\text { Integreer mitigerend beleid } \\
\text { in politieke besluitvorming }\end{array}$ & $\begin{array}{l}\text { HF-bodemgegevens dragen } \\
\text { bij aan het voorspellen van } \\
\text { de vochttoestand van de } \\
\text { bodem onder veranderend } \\
\text { klimaat. De vochttoestand } \\
\text { heeft een bewezen forse } \\
\text { relatie met de mate van } \\
\text { emissie van broeikasgassen }\end{array}$ & $\begin{array}{l}\text { De combinatie van } \\
\text { vochttoestand, mestsoorten } \\
\text { en bodemgegevens zijn } \\
\text { cruciaal bij emissiereductie. } \\
\text { Dergelijk onderzoek wordt } \\
\text { meegenomen in } \\
\text { beleidsvorming }\end{array}$ \\
\hline $\begin{array}{l}17 . \\
\text { Partnerschap om } \\
\text { doelstellingen te bereiken }\end{array}$ & $\begin{array}{l}\text { Aantal samenwerkings- } \\
\text { overeenkomsten en } \\
\text {-programma's inzake SDG } \\
\text { gerelateerde } \\
\text { gegevensverwerking }\end{array}$ & $\begin{array}{l}\text { - Samenwerking met TNO } \\
\text { inzake BRO } \\
\text { - Lid van het European Soil } \\
\text { Bureau Network } \\
\text { - Samenwerking met ISRIC } \\
\text { - World Data Center for } \\
\text { Soils }\end{array}$ & \\
\hline
\end{tabular}

\subsection{Aanleiding en probleemstelling}

Het huidige totaal aantal betrouwbare hydrofysische bodemgegevens voor een bodemkundig informatiesysteem is nog niet toereikend om landsdekkende dan wel regionale studies uit te kunnen voeren. De Staringreeks (Wösten et al., 1987, 1994, 2001) geeft weliswaar gemiddelden van de hydraulische karakteristieken, maar bevat geen gegevens van afzonderlijke monsters. Het bevat ook geen beschrijvende gegevens, omdat de gegevens van verschillende monsterplekken zijn geclusterd tot gemiddelde bouwstenen. Bovendien zijn de gegevens voor een groot deel gebaseerd op data van meer dan 30 jaar geleden. 
Gebruikers van hydrofysische bodemgegevens hebben behoefte aan meer differentiatie, recentere gegevens, een hogere betrouwbaarheid van de gemiddelde karakteristieken per bouwsteen en aan de beschrijvende gegevens per monsterlocatie. Met de Priapus-database is daartoe een eerste aanzet gedaan: het maakt een bredere toepassing van de data mogelijk dan de Staringreeks, omdat op monsterniveau eigenschappen zijn te vergelijken. Bovendien hebben de afgeleide data, die uit verschillende bronnen zijn verzameld, een strenge kwaliteitsslag ondergaan. Er is echter behoefte aan veel meer kwalitatief hoogwaardige en recente hydrofysische bodemdata, die tevens geschikt zijn voor opschaling op basis van meerdere criteria, zoals boven- en ondergrond, gehalte aan organische stof, textuur en afzettingsmilieu. Behalve aan de afgeleide gegevens is er ook behoefte aan de meetdata die aan de afgeleide data ten grondslag liggen, zodat nieuwe wetenschappelijke inzichten optimaal gebruikt kunnen worden, resulterend in bijvoorbeeld verbeterde afgeleide datasets. De meetdata zijn niet aanwezig in de Staringreeks en Priapus. Daarom is in de periode 2012-2014 een start gemaakt met het overbrengen van oude Priapus-data naar de BIS-omgeving. Het overbrengen gebeurt gefaseerd, om essentiële ontbrekende data uit de literatuur alsnog toe te kunnen voegen. De prioriteit ligt bij het jaarlijks verzamelen van nieuwe kwalitatief hoogwaardige HF-bodemdata om aan BIS toe te kunnen voegen.

\subsection{Projectdoelstelling}

Het hoofddoel van dit project is het aanvullen van BIS-gegevens met nieuwe, kwalitatief hoogwaardige hydrofysische bodemdata die voldoen aan de eisen zoals hierboven zijn omschreven. De nieuw verkregen afgeleide data alsook de meetdata worden in dit project ondergebracht in BIS en kunnen daardoor op eenvoudige en eenduidige wijze gebruikt worden, ook in combinatie met andere in BIS opgeslagen bodemkundige gegevens. Door eenduidige ontsluiting in BIS kan het vervolgens relatief eenvoudig ondergebracht worden in het Nederlandse BRO en het Europese INSPIRE: systemen die beleidsmakers en andere gebruikers helpt bij het beantwoorden van lokale, nationale en grensoverschrijdende vraagstukken.

\subsection{Leeswijzer}

In hoofdstuk 1 is voornamelijk aandacht besteed aan het belang van hydrofysische bodemgegevens voor onderzoek en aan de geschiedenis en toekomst van hydrofysische bodemdata. Hoofdstuk 2 geeft een overzicht van de gebruikte veld- en laboratoriummethoden. Hoofdstuk 3 is een vrij uitgebreide presentatie van de belangrijkste componenten van de veld-, laboratorium- en deskgegevens in tabelvorm. Voor verdere details wordt verwezen naar de BIS-database. Hoofdstuk 4 geeft een korte terugblik op de resultaten, het gebruik van de resultaten en een doorkijk naar de toekomst.

In de bijlagen is een overzicht gegeven van de modellen die gebruik maken van hydrofysische gegevens, is het voor dit onderzoek ontwikkelde analyseprogramma voor hydrofysische eigenschappen toegelicht, is een overzicht gegeven van de 38 opschalingseenheden, en is voornamelijk ook gedetailleerde informatie opgenomen over de veldwaarnemingen en de analyseresultaten van de bodemmonsters. Tot slot zijn de codes voor de Bodemkundige Karakterisering opgenomen, de indeling van de Staringreeks en een overzicht van het aantal monsters per opschalingseenheid en per Staringreeksbouwsteen. 


\section{$2 \quad$ Materialen en methoden}

Dit hoofdstuk geeft een toelichting op de keuze van de te verzamelen gegevens en op de veld- en laboratoriummethoden die gebruikt zijn om deze gegevens vast te stellen en te interpreteren.

\subsection{Gegevenskeuze, kwaliteit en presentatie}

\subsubsection{Welke hydrofysische bodemgegevens in BIS}

Het is voor nieuwe monsters binnen de huidige omstandigheden niet mogelijk om alle hydrofysische bodemgegevens te bepalen en op te nemen in BIS. Daarom kiezen we voor een selectie van de meest gebruikte parameters. De parameters zijn in overeenstemming met de kwaliteitscriteria zoals die in de volgende paragraaf worden besproken:

1. Textuur

2. Droge bulkdichtheid

3. Gloeiverlies (als maat voor het organische stofgehalte)

4. Verzadigde waterdoorlatendheid

5. Waterretentiekarakteristiek: het verband tussen watergehalte $\theta\left(\mathrm{cm}^{3} \mathrm{~cm}^{-3}\right)$ en drukhoogte $h(\mathrm{~cm})$

6. Waterdoorlatendheidskarakteristiek: het verband tussen doorlatendheid $K\left(\mathrm{~cm} \mathrm{~d}^{-1}\right)$ en $\theta$ of $h$

7. Beschrijving van de retentie- en doorlatendheidskarakteristiek met de Mualem-Van Genuchtenvergelijkingen

8. Profielbeschrijving

9. Landgebruik huidig en vorig jaar

10. Coördinaten

11. Geocode

Voor de punten 5 en 6 geldt dat de hydraulische karakteristieken (retentiekarakteristiek en waterdoorlatendheidskarakteristiek) met verschillende analytische vergelijkingen beschreven kunnen worden. Omdat geen enkel model in staat is om de metingen volledig correct te beschrijven en omdat er nog steeds nieuwe modellen worden ontwikkeld, is ervoor gekozen om van deze items in ieder geval alle betrouwbaar geachte ruwe meetgegevens (zie 2.4.3) op te nemen in BIS. Met de ruwe gegevens is de gebruiker dus altijd in staat om met eigen voorkeursmodellen een complete set hydrofysische parameters af te leiden, de zogenaamde afgeleide gegevens. Dit maakt de reeks ook voor toekomstig gebruik geschikt.

Omdat de Mualem-Van Genuchten-vergelijkingen momenteel wereldwijd erg veel gebruikt worden, zijn deze modelparameters, bij wijze van voorbeeld, eveneens in BIS opgenomen. Om de datareeks in BIS te vergroten, worden kwalitatief hoogwaardige afgeleide data uit de bestaande Priapus-database ook in BIS opgenomen. Van deze gegevens zijn de ruwe meetgegevens helaas niet altijd meer te achterhalen. In die gevallen kan niet aan de bovengenoemde compleetheidseisen worden voldaan, maar worden de gegevens (met name de Mualem-van Genuchten parameters) toch opgenomen. Daar waar nodig worden ze gekoppeld aan 'dummy' bodemprofielen.

\subsubsection{Kwaliteitscriteria}

De kwaliteitscriteria voor de hydrofysische bodemdata die zijn ondergebracht in Priapus, staan vermeld in Stolte et al. (2007) en in Verzandvoort et al. (2012). Deze kwaliteitscriteria gelden, met het overbrengen van oude Priapus-data naar BIS en voor nieuw te analyseren monsters, ook voor de data in BIS. Een belangrijke toevoeging van BIS is dat tenminste ook de ruwe meetdata worden opgenomen. De kwaliteitseisen zijn enerzijds gebaseerd op de volledigheid van de metagegevens, parametersoorten en meetbereik en anderzijds op de kwaliteit van de gegevens zelf, zoals die van de afgeleide waterdoorlatendheidsdata en de Mualem-Van Genuchten-krommen. In Tabel 2.1 zijn - in het 
kader van het nastreven van de minimaal benodigde informatie - de hoofdgroepen gegeven die opgenomen worden in BIS. Oude gegevens uit Priapus die opgenomen worden in BIS voldoen eveneens aan de kwaliteitscriteria, maar niet in alle gevallen aan de volledigheidseisen.

Tabel 2.1 Hoofdgroepgegevens (minimale variant) van de hydrofysische bodemdata in BIS. In individuele gevallen kan hier per MonsterId in BIS gemotiveerd van worden afgeweken.

\begin{tabular}{|c|c|}
\hline Hoofdgroepnaam & Omschrijving \\
\hline \multicolumn{2}{|l|}{ Veldgegevens } \\
\hline Profielbeschrijving & Beschrijving bodemopbouw tot $1,5 \mathrm{~m}-\mathrm{mv}$ \\
\hline Coördinatenstelsels & Beschrijving van coördinatenstelsels \\
\hline Bodemgebruik & Beschrijving van bodemgebruik huidig jaar en vorig jaar \\
\hline Grondwatertrappen & Definities van grondwatertrappen \\
\hline Gt & Aangetroffen grondwatertrap \\
\hline Geologie & Beschrijving van geologische ondergrond (Geocode) \\
\hline GrondsoortLegenda & Beschrijving van grondsoorten \\
\hline Grondsoort & Grondsoorten waarop indeling Staringreeks is gebaseerd \\
\hline Kwaliteit & Kwaliteitscodering van grondmonsters \\
\hline Kwaliteitscodes & Beschrijving van de kwaliteitscodering \\
\hline Eigenschappen & De hydrofysische bodemeigenschappen van de grondmonsters \\
\hline Textuur & Gemeten textuurgegevens van bodemmonsters \\
\hline TextuurClassificatieSystemen & Beschrijvingen van classificatiesystemen voor textuur \\
\hline TextuurClassificatieGrenzen & Definities van textuurklassen \\
\hline Metingen & Gegevens over de metingen \\
\hline Meetmethoden & De gebruikte meetmethoden \\
\hline Standaardreeks & Vochtgehalte en doorlatendheid bij standaard drukhoogte \\
\hline VanGenuchtenParams & De gefitte parameters van de Mualem-Van Genuchten vergelijkingen voor de monsters \\
\hline StandaardDrukhoogte & De 13 standaard drukhoogten die gebruikt worden voor de Standaardreeks \\
\hline
\end{tabular}

De afgeleide gegevens zijn alle gecontroleerd op consistentie en fysische verklaarbaarheid. De afgeleide gegevens kunnen soms afwijkend gedrag vertonen. Dit kan optreden door meetfouten, maar ook door ruis, temperatuurinvloeden of als het gebruikte model onvoldoende in staat is om de metingen te fitten. In de eerste drie gevallen, waarin de afgeleide gegevens leidden tot twijfel over een of meerdere gemeten datapunten of zelfs over een hele tensiometerreeks, zijn deze datapunten niet gepresenteerd in dit rapport en niet opgenomen in de BIS-database. Indien daarentegen de afgeleide gegevens onvoldoende nauwkeurig door het model kunnen worden beschreven terwijl de meetgegevens zelf betrouwbaar worden geacht, zijn de daaraan ten grondslag liggende metingen wel in BIS opgenomen. In het overgrote deel van de gevallen zullen kleine drukhoogtegradiënten in het natte traject de reden zijn om specifieke $K(h)$-datapunten (doorlatendheid) uit te sluiten van de $K(h)$-datareeks in BIS. Deze kleine gradiënten zijn overigens niet te vermijden en inherent aan de gebruikte methode en fysische eigenschappen van het monster gedurende het verdampingsproces. Voor $\theta(h)$-reeksen ( $p F$-curve) is de drukhoogtegradiënt veel minder gevoelig en worden voor deze specifieke toepassing wel in BIS toegestaan. De selectie van deze voorwaarden gebeurt al in een vroeg stadium bij het genereren van afgeleide gegevens met behulp van een datafilter (Heinen et al., 2016a). 


\subsection{Selectiewijze monsterlocaties}

De indelingscriteria voor bemonstering, zoals voorgesteld door Verzandvoort et al. (2012) zijn: bovenof ondergrond ( 2 klassen), afzettingsmilieu ( 6 hoofdklassen), waarbinnen textuur (6 leemklassen, 5 klassen op basis van mediaan zandfractie en 10 lutumklassen) en organische stofgehalte ( 6 klassen bij minerale gronden, 3 klassen bij moerige gronden), met een totaal van 38 indelingseenheden. Het aantal mogelijke combinaties wordt daarmee maximaal 2364 (Knotters et al., 2011). Als in elke eenheid ten minste 2 monsterlocaties moeten liggen, betekent dit een steekproefomvang die op dit moment niet haalbaar is. Omdat niet alle 2364 combinaties kunnen worden bemonsterd, is door Knotters et al. (2011) de Latin Hypercube sampling-methode voorgesteld om met een beperkt aantal monsters zo veel mogelijk hydrofysische bodeminformatie toe te voegen aan de BIS- en BROdatabase.

\subsubsection{Latin Hypercube Sampling}

Bij de opzet van de aanvullende steekproef en bij de ruimtelijke opschaling kan wel rekening worden gehouden met het feit dat niet alle opschalingseenheden steekproefpunten bevatten (empty domains). Belangrijk is dat in alle klassen waarop de indeling in opschalingseenheden is gebaseerd, monsters liggen. Indien dit wordt voorgesteld als een tabel met rijen en kolommen, betekent dit dat niet alle vakjes zijn gevuld, maar dat wel alle rijen en kolommen informatie bevatten. Dit kan worden bewerkstelligd door Latin Hypercube Sampling. Bij de bemonstering is de aanbeveling gevolgd dat zo veel mogelijk klassen naar boven- en ondergrond, afzettingsmilieu, textuur en gehalte aan organische stof uiteindelijk in BIS en BRO worden opgenomen met ten minste twee monsters per klasse. Meerdere monsters per klasse zijn nodig om de nauwkeurigheid van geschatte gemiddelden te kunnen kwantificeren of om benaderingen, waarbij wordt geloot uit bodemfysische karakteristieken, voor individuele locaties mogelijk te maken (bootstrapping).

Knotters et al. (2011) bevelen aan om de monsterlocaties gericht te selecteren, met als doel de hiaten in Priapus op te vullen. Geconcludeerd werd dat er minimaal 50 aanvullende horizonten bemonsterd moeten worden voor een goede dekking van de ruimtelijke hoofdaggregatie-eenheden. In voorliggend project is besloten dat ook inzicht in de spreiding van de meetresultaten van een enkele locatie nodig is. Daarom worden steeds duplomonsters genomen. Uitvoering in duplo betekent dat er minimaal 100 monsters per bepalingsmethode genomen en doorgemeten moeten worden. De finale minimale streefwaarde per opschalingseenheid wordt daarmee 3 monsters als ook oudere individuele (geen duplo) monsters mee doen in de telling. Bij de bemonstering en analyse is bij de start van het project een prioriteitsvolgorde aangehouden: de grootste oppervlakten per opschalingseenheid zijn daarbij het eerst gemonsterd. De prioritering ligt nu bij het vullen van de niet, of onvoldoende, in het veld aangetroffen opschalingseenheden.

\subsubsection{Selectiewijze bemonsteringslocaties}

In BIS zijn op dit moment al duizenden profielbeschrijvingen beschikbaar van locaties verspreid over Nederland. Bij het zoeken naar geschikte bemonsteringslocaties is daarvan gebruikgemaakt. Bij het selecteren van de locaties is een aantal criteria gehanteerd:

- De gewenste textuurklasse moet aanwezig zijn over een dikte van ten minste $20 \mathrm{~cm}$, zodat de kans op voorkomen wordt vergroot en er een voldoende diep profiel voor bemonstering aanwezig is.

- De gewenste textuurklasse moet aanwezig zijn in de boven- of ondergrond

- De locatie heeft de geologische ontstaanswijze zoals beoogd voor de doeleenheid.

Vanuit de verkregen selectie is een overzicht met locatie- en contactgegevens gegenereerd. De potentiële bemonsteringslocaties zijn daarna verder handmatig geselecteerd op basis van de volgende eigenschappen:

- De bemonsteringslocaties moeten voldoende verspreid over Nederland liggen. Er is bijvoorbeeld rekening gehouden met bemonstering van locaties van mariene afkomst uit zowel het zuidwesten als het noorden.

- Om de kans op aantreffen van de betreffende textuur in het veld te vergroten, zijn locaties aan de randen van een kaartvlak van de Bodemkaart van Nederland (schaal 1: 50 000) vermeden, omdat 
daar de variatie in textuur groter is. In het algemeen geldt dat naarmate de profielbeschrijvingen ouder zijn, de locaties minder nauwkeurig zijn vastgelegd.

- In een aantal gevallen was het praktisch om op dezelfde locatie zowel een boven- als ondergrond te bemonsteren.

Van de locaties die aan alle criteria voldeden, zijn de eigenaren benaderd om toestemming voor bemonstering te vragen.

\subsection{Bemonsteringswijze}

Op de geselecteerde locaties zijn de volgende monsters in duplo genomen in het midden van de betreffende horizont:

- Roestvrijstalen monsterringen (hoogte $H=5 \mathrm{~cm}$, diameter $D \approx 5 \mathrm{~cm}$; inhoud $100 \mathrm{~cm}^{3}$ ) voor onverstoorde monsters ten behoeve van de bepaling van de retentiecurve op de zandbak voor het traject $h=0$ tot $-100 \mathrm{~cm}(\mathrm{pF}=2)$.

- PVC-monsterringen $(H=8 \mathrm{~cm}, D \approx 10 \mathrm{~cm})$ voor onverstoorde monsters ten behoeve van de bepaling van de retentiecurve en curve van de onverzadigde waterdoorlatendheid op de verdampingsopstelling voor het traject $h=-10$ tot $-700 \mathrm{~cm}(\mathrm{pF}=1$ tot $\mathrm{pF}=2.8)$.

- PVC-monsterringen $(H=10 \mathrm{~cm}, D \approx 20 \mathrm{~cm}$ ) voor onverstoorde monsters ten behoeve van de bepaling van de verzadigde waterdoorlatendheid $(h=0)$.

- Verstoorde grondmonsters in zakken ter bepaling van de textuur en organische stof.

De ringen voor de onverstoorde monsters zijn dusdanig voorzichtig met de hand in de grond gebracht dat de structuur van de grond behouden is gebleven. Daarna zijn de monsterringen rondom uitgegraven en handstrak met folie omwikkeld zodat er geen grond uit de ringen kon vallen. In het lab zijn de monsters verder geprepareerd. De $100 \mathrm{~cm}^{3}$ ringen zijn in het veld al geprepareerd met een vlakke boven- en onderzijde. Vervolgens zijn de monsters dezelfde dag nog bij 4 graden Celsius opgeborgen voor verdere analyse in het lab. Bij de bemonstering van de ondergronden is de bovengrond eerst voorzichtig afgegraven tot de bovenzijde van het benodigde profiel, waarbij de bovenzijde netjes vlak is afgewerkt. Het eigenlijke profiel is daarbij onverstoord gebleven, hetgeen betekent dat er niet overheen is gelopen en niet verticaal met de schop in is gestoken.

Tijdens monstername is tevens een profielbeschrijving gemaakt en zijn onder andere de volgende gegevens genoteerd op de veldcomputer:

- Monsternaam

- Locatie

- $X Y$ coördinaten

- Horizont

- Diepte boven- en onderkant monster

- Monsterdatum

- Monsternemer

- Bodemgebruik

- Grondwatertrappen (GtCode, GLG, GHG)

- Geologische ondergrond

- Grondsoort

\subsection{Analysemethoden}

\subsubsection{Textuur}

Voor bodemkartering worden van oudsher de textuurklassen van de Stiboka (Stichting voor Bodemkartering) gebruikt. Voor kleigronden werden andere fractieverdelingen gehanteerd dan voor zandgronden. De Nederlandse norm NEN 5753/C1 (2006, 2009) en de gelijksoortige internationale norm ISO 11277 (2009) schrijven geen specifieke fracties voor, maar geven wel een overzicht van de 
meest gebruikte fracties. De Rijks Geologische Dienst (RGD) gebruikt enigszins afwijkende fractieverdelingen in het bereik 50 tot $150 \mu \mathrm{m}$. Voor de nieuw te analyseren monsters voor BIS wordt een combinatie van genoemde systemen aangehouden, zodat ze geldig zijn ongeacht de gehanteerde indeling. Voor een uniforme verdeling worden voor alle grondsoorten dezelfde verdelingen aangehouden.

In Tabel 2.2 zijn de gehanteerde textuurklassen weergegeven en de laboratoriummethode die voor de fractiebepaling is gebruikt. De gebruikte laboratoriummethoden zijn beschreven in de ISO 11277 (2009). Uitgegaan wordt van de fracties ten opzichte van de minerale delen, waarvan de hoofdonderdelen als volgt worden benoemd:

- Lutum: 0 - $2 \mu \mathrm{m}$

- Silt: 2 - $50 \mu \mathrm{m}$

- Leem: 0 - $50 \mu \mathrm{m}$

- Zand: $50-2000 \mu \mathrm{m}$

De fractie $<63 \mu \mathrm{m}$ wordt in het Chemisch Biologisch Laboratorium Bodem (CBLB; Wageningen) geanalyseerd volgens de pipet- en natte-zeefmethode. De fractie $63-2000 \mu \mathrm{m}$ wordt daarna in het Bodemfysisch Laboratorium van Wageningen UR verder geanalyseerd door middel van droogzeven.

In het laboratorium wordt de op < $2000 \mu \mathrm{m}$ voorgezeefde grond met waterstofperoxide voorbehandeld om aanwezige organische stof te oxideren. Daarna volgt een behandeling met zoutzuur om aanwezige carbonaten in oplossing te brengen. Voor ijzerrijke grond kan het gewenst zijn de korrelgrootteverdeling van de minerale delen zonder ijzeroxide te bepalen. Hierbij wordt het aanwezige ijzeroxide in oplossing gebracht. Na verwijdering van het organische stof, carbonaten en ijzer, resteert de minerale fractie. Deze minerale fractie wordt door zeven in twee fracties verdeeld. De hoofdfractie met grovere deeltjes wordt gedroogd en gewogen en via zeven met verschillende maaswijdte onderverdeeld in sub-fracties en vervolgens nogmaals gewogen. De hoofdfractie met de kleinere deeltjes wordt onderverdeeld in sub-fracties op basis van verschil in bezinkingssnelheid. Hierbij wordt van een suspensie van het monster in een maatcilinder, na toevoeging van een peptisatiemiddel op verschillende tijdstippen en diepten, in de cilinder een monster gepipetteerd. Tijdstippen en diepten voor het pipetteren van bepaalde fracties worden met de wet van Stokes berekend. De gepipetteerde suspensie wordt ingedampt en gedroogd en door weging wordt het massapercentage van de gepipetteerde fractie bepaald.

Tabel 2.2 Gehanteerde fracties voor BIS en de gebruikte labmethode.

\begin{tabular}{ll} 
Textuurklasse $(\mathrm{\mu m})$ & Gebruikte methode \\
$<2$ & Pipetmethode \\
$2-16$ & Pipetmethode \\
$16-50$ & Pipetmethode \\
$50-63$ & Natte-zeefmethode \\
$63-105$ & Droge-zeefmethode \\
$105-150$ & Droge-zeefmethode \\
$150-210$ & Droge-zeefmethode \\
$210-420$ & Droge-zeefmethode \\
$420-2000$ & Droge-zeefmethode \\
\hline
\end{tabular}

De fracties 0-2000 $\mu \mathrm{m}$ worden in het laboratorium bepaald ten opzichte van de minerale delen. De fracties 0-2000 $\mu \mathrm{m}$ tezamen geven daarom altijd een totaal van $100 \%$. In het veld worden de textuurfracties net als in het laboratorium bepaald ten opzichte van de minerale delen (Cate, ten et al., 1995). Het is daarmee mogelijk om een directe vergelijking te maken tussen de veldschattingen en de in het lab bepaalde textuurverdeling. Het organische stofgehalte wordt daarentegen in het veld en in het laboratorium bepaald ten opzichte van massa van de stoofdroge grond. Een sommatie van de textuur, organische stof, carbonaten en ijzer kan daarom resulteren in een waarden van meer dan $100 \%$. De textuurbenamingen in veld en laboratorium worden eveneens uitgevoerd op basis van de hierboven omschreven resultaten van textuur en organische stof. 
Uit de laboratoriumbepalingen wordt ook het M50-getal berekend. Het M50-getal wordt overigens ook door de veldmedewerker geschat. Het M50-getal is de mediane fractie in het bereik 50-2000 $\mu \mathrm{m}$, ofwel de korrelgrootte waarboven 50\% van het gewicht zich bevindt binnen dit bereik. Omdat het hier om een procentuele waarde gaat, verandert het M50-getal niet als men er toch voor kiest om de textuur uit te drukken als percentage van de massa stoofdroge grond.

\subsubsection{Gloeiverlies}

Het gloeiverlies (Eng: loss-on-ignition) is een maat voor het organisch stofgehalte van een grondmonster. Hoe groter het aandeel organisch materiaal, hoe groter het gloeiverlies zal zijn. In het laboratorium wordt het in het veld genomen verstoorde grondmonster gezeefd over een zeef met $2 \mathrm{~mm}$ maaswijdte. De fractie kleiner dan $2 \mathrm{~mm}$ wordt gedroogd bij $105^{\circ} \mathrm{C}$, gewogen en vervolgens gegloeid bij $550^{\circ} \mathrm{C}$. Het gloeiverlies $w_{g v}$ wordt vervolgend berekend uit

$w_{g v}=\frac{m_{105}-m_{550}}{m_{105}-m_{0}} \times 100 \%$

waarin:

$w_{g v} \quad=$ gloeiverlies op basis van stoofdroge grond (\%);

$m_{0} \quad=$ massa van het lege kroesje $(\mathrm{g})$;

$m_{105}=$ massa van het kroesje met het stoofdroge monster $(\mathrm{g})$;

$m_{550}=$ massa van het kroesje met het gegloeide monster $(\mathrm{g})$.

Het organische stofgehalte is per definitie kleiner of gelijk aan het gloeiverlies. Het organische stofgehalte kan volgens de NEN 5754 bepaald worden door de gloeiverliesbepaling vergezeld te laten gaan van een lutumgehaltebepaling en een bepaling van het gehalte aan vrij ijzer. Het OS-gehalte wordt dan als volgt berekend:

$w_{O S}=w_{g v}-0.07 * L-0.12 * Y$

waarin:

$W_{O S}=$ organisch stofgehalte van stoofdroge grond (\%);

$L \quad=$ lutumgehalte $(\%)$;

$Y \quad=$ gehalte aan vrij ijzer (\%). (Alleen corrigeren bij $Y>5 \%$.)

\subsubsection{Retentie- en onverzadigde waterdoorlatendheidskarakteristiek}

De retentiekarakteristiek wordt bepaald met behulp van drie verschillende laboratoriumopstellingen:

- Zandbak voor het bereik $h=0$ tot $-100 \mathrm{~cm}(\mathrm{pF} \leq 2)$

- Verdampingsopstelling voor het bereik $h=-10$ tot $-700 \mathrm{~cm}(1 \leq \mathrm{pF} \leq 2,8)$

- Drukpanopstelling voor het bereik $h=-1000$ tot $-15000 \mathrm{~cm}(3 \leq \mathrm{pF} \leq 4,2)$

De karakteristiek voor de onverzadigde waterdoorlatendheid wordt bepaald met behulp van de verdampingsopstelling voor het bereik $h=-50$ tot $-700 \mathrm{~cm}(1,7 \leq \mathrm{pF} \leq 2,8)$. De metingen vinden plaats in het bodemhydrofysisch laboratorium van Wageningen UR onder strenge temperatuur- en vochtigheidscondities.

\subsubsection{Zandbakmethode en droge bulkdichtheid}

Voor deze methode wordt een onverstoord gestoken grondmonster van $100 \mathrm{~cm}^{3}$ in een roestvrijstalen monsterring $(H=5 \mathrm{~cm}, D \approx 5 \mathrm{~cm}$ ) aan de boven- en onderzijde vlak afgewerkt. Op deze wijze ontstaat een monster met een nauwkeurig bekend grondvolume. Eén zijde wordt voorzien van een nylongaasje. Het monster wordt van onderaf met water verzadigd en vervolgens met het nylongaasje op de zandbak geplaatst. De zandbak bevat een fijn gesorteerde grondsoort die een hoge doorlatendheid combineert met een kleine poriediameter. De drukhoogte van de grond in de bak zelf blijft in het te meten gebied, van $h=0$ tot ongeveer $-100 \mathrm{~cm}$, nagenoeg verzadigd. Door middel van een drainagebuis onder in de bak die verbonden is met een waterreservoir, kan het bodemwater op elke gewenste zuigspanning worden gebracht. Door het monster in contact te brengen met deze zuigspanning, zal het water in het monster deze zuigspanning overnemen en zal er water uit het 
monster stromen (desorptie). Zodra na herhaaldelijk wegen geconcludeerd wordt dat er geen water meer uit het monster stroomt en het monster dus in evenwicht is met de aangelegde zuigspanning, wordt het monster definitief gewogen. Vervolgens wordt een nieuwe zuigspanning aangelegd en wordt de procedure herhaald. Zodra alle zuigspanningen op deze wijze zijn doorgemeten, wordt het monster gedroogd bij $105^{\circ} \mathrm{C}$ en wordt het opnieuw gewogen. Dit resulteert in de droge bulkdichtheid, waarvan de methode is beschreven in de ISO 11272, (1998). Al het water is nu uit het monster verdwenen en de volumetrische vochtgehalten bij de aangelegde zuigspanningen kunnen worden berekend. De methode is beschreven in de ISO 11274 (1998).

\subsubsection{Verdampingsmethode}

De verdampingsmethode wordt gebruikt om een deel van de retentie- en onverzadigde waterdoorlatendheidskarakteristiek te bepalen. Voor deze methode (ISO 11275, 2004) wordt een onverstoord gestoken grondmonster van circa $600 \mathrm{~cm}^{3}$ in een PVC-monsterring $(H=8 \mathrm{~cm}, D \approx 10 \mathrm{~cm})$ aan de boven- en onderzijde vlak afgewerkt. Op deze wijze ontstaat een monster met een nauwkeurig bekend grondvolume. Het monster wordt van onderaf verzadigd, aan de onderzijde afgesloten met een water- en luchtdichte bodemplaat en vervolgens op een weegschaal geplaatst. Om verdamping mogelijk te maken, staat de bovenzijde bloot aan de omgevingslucht. De drukhoogte wordt op bekende tijdstippen in het monster gemeten met 4 horizontaal georiënteerde tensiometers die op gelijke verticale afstanden worden geplaatst. Ook de tensiometerdoorgangen in de monsterring zijn lucht- en waterdicht afgesloten, zodat hierdoor geen verdamping kan optreden.

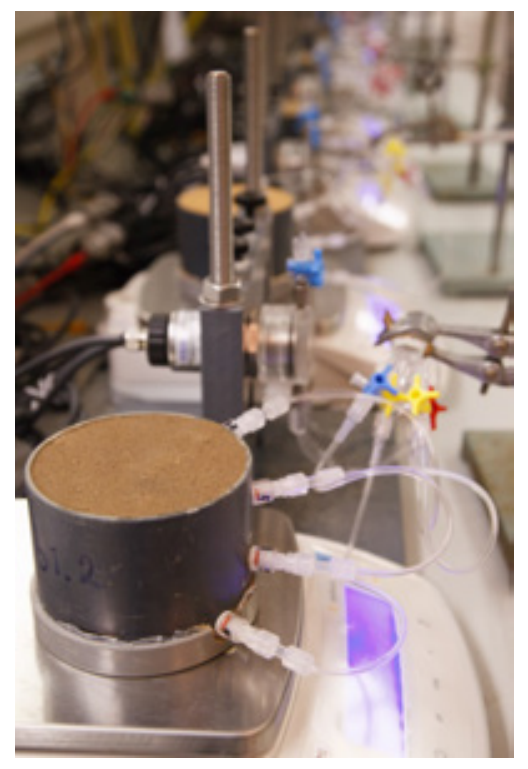

Figur 2.1 Verdampingsmethode

Naast de drukhoogten bepaalt men op dezelfde tijdstippen het totale gewicht van het monster (monster staat permanent op een digitale weegschaal). Hieruit berekent men de afname van het totale watergehalte door verdamping. Zodra de water gevulde tensiometers stoppen met werken, meestal in de buurt van de $h=-700$ tot $-900 \mathrm{~cm}$, bepaalt men het ovendroge gewicht van het monster, zodat het gemiddelde watergehalte op elk tijdstip is terug te rekenen. De data worden verkregen met een geautomatiseerde opstelling die door Wageningen UR in eigen beheer is ontwikkeld (zie Figuur 2.1).

In paragraaf 2.5 wordt nader omschreven hoe uit de ruwe meetdata (totale monstergewichtsafname (verdamping) en drukhoogtes op 4 dieptes) datapunten voor de waterretentiekarakteristiek en doorlatendheidskarakteristiek worden afgeleid.

\subsubsection{Drukpanmethode}

Met een hangende waterkolom, zoals aangebracht met de zandbakopstelling (paragraaf 2.4.3.1), kan een maximale theoretische zuigspanning van $1000 \mathrm{~cm}$ worden aangebracht. Vanaf dat punt zal het 
water gaan koken en is een betrouwbare meting niet meer mogelijk. Om toch bij grotere zuigspanningen te kunnen meten, wordt met een overdruk in plaats van een onderdruk gewerkt. Verschillende kleine verzadigde bodemmonsters worden op een met water verzadigde keramische plaat geplaatst. De keramische plaat wordt vervolgens in een drukpan gemonteerd. De keramische plaat is aan de onderzijde afgesloten met een rubbermat. Tussen de plaat en de mat bevindt zich water. Door de plaat zit een afvoerbuisje naar de bovenzijde van de plaat, dat met een slangetje naar een punt buiten de drukpan wordt geleid. De onderzijde van het afvoerbuisje bevindt zich tussen de rubbermat en het keramiek en is daarmee in staat water naar buiten af te voeren dat door de poriën van de keramische plaat wordt getransporteerd. Door middel van een overdruk in de drukpan wordt er een waterpotentiaal aangebracht tussen het water in het monster en de buitenlucht. De atmosferische druk wordt via een dunne slang overgebracht van buiten de drukpan naar de afgesloten onderzijde van de keramische plaat. Door de fijne poriestructuur van de plaat is de overdruk niet in staat om de poriën die gevuld zijn met water leeg te drukken. Wel kan er via de watergevulde poriën watertransport plaatsvinden vanuit het monster door de plaat en het slangetje naar buiten. Zodra het monster in evenwicht is met de aangelegde druk, wordt de druk weggenomen en worden de monsters gewogen. Daarna worden ze gedroogd bij $105^{\circ} \mathrm{C}$ en nogmaals gewogen. Om het volumetrisch vochtgehalte te kunnen bepalen, is dan wel nog de droge bulkdichtheid van een onverstoord monster nodig (meestal de droge bulkdichtheid van het monster dat bij de verdampingsmethode of de zandbakmethode is gebruikt):

$\theta=\frac{\rho_{d}}{\rho_{l}} w$

waarin:

$\rho_{d} \quad=$ droge bulkdichtheid $\left(\mathrm{kg} \mathrm{m}^{-3}\right)$

$\rho_{l} \quad=$ dichtheid van water $\left(\mathrm{kg} \mathrm{m}^{-3}\right)$

$w \quad=$ watergehalte op gewichtsbasis en is gelijk het gewicht van het water in het monster gedeeld door het gewicht aan van de ovendroge grond $\left(\mathrm{kg} \mathrm{kg}^{-1}\right)$

Bij deze hoge zuigspanningen kunnen kleine, verstoorde grondmonsters worden gebruikt. De methode wordt gebruikt voor het meetbereik van $h=-1000$ tot $-15000 \mathrm{~cm}(3 \leq \mathrm{pF} \leq 4,2)$. De methode is beschreven in de ISO 11274 (1998).

\subsubsection{Verzadigde waterdoorlatendheid}

Een niet-verstoord, homogeen grondmonster in een ring $(H=10 \mathrm{~cm} ; D=20 \mathrm{~cm})$ wordt in een opstelling geplaatst. Het monster wordt geheel verzadigd met water. Boven op het grondmonster wordt een waterlaag met constante hoogte gehandhaafd. Bovendien wordt de onderzijde van het monster geheel verzadigd gehouden. Er wordt een constante stijghoogtegradiënt ingesteld door de uitstroomslang op een vaste positie te houden. Door de hoeveelheid uitstromend water per tijdseenheid te meten, kan de verzadigde waterdoorlatendheid $K_{s}$ volgens de wet van Darcy worden bepaald:

$k_{s}=\frac{V}{|\nabla H| \cdot \Delta t \cdot A}$

waarin:

$k_{s} \quad=$ verzadigde waterdoorlatendheid $\left(\mathrm{cm} \cdot \mathrm{d}^{-1}\right) ; \mathrm{d}=24$ uur

$V \quad=$ volume water dat gedurende $\Delta t$ is uitgestroomd $\left(\mathrm{cm}^{3}\right)$

$|\nabla H|=$ absolute hydraulische stijghoogtegradiënt $\left(\mathrm{cm} \mathrm{cm}^{-1}\right)$

$A=$ oppervlakte van het grondmonster $\left(\mathrm{cm}^{2}\right)$

$\Delta t \quad=$ tijd waarin het uitstromende water is gemeten $(\mathrm{d})$

Voor de meting wordt afgeweken van de NEN 5789 (1991). De NEN gaat uit van vrije uitstroom aan de onderzijde van het monster. Omdat in dat geval onverzadigde delen aan de onderzijde van het monster ontstaan en de te overwinnen cohesie- en adhesiekrachten aan de onderzijde ongelijk aan nul zijn, is de gemeten waterdoorlatendheid lager dan de werkelijke verzadigde waterdoorlatendheid. Door de onderzijde verzadigd te houden, wordt dit probleem ondervangen (Vos, de et al., 1997). 


\subsection{Afgeleide gegevens}

\subsubsection{Ontwikkeling van Filter en Rekensheet in Excel}

Na de metingen in het laboratorium worden de meetgegevens gebruikt om datareeksen voor retentiecurven en doorlatendheidscurven vast te stellen. Hiervoor zijn achtereenvolgens een aantal (rekenkundige) bewerkingen nodig:

a. Data-filtering

b. Genereren datareeksen voor retentiekarakteristiek per bodemcompartiment door het uitvoeren van een PreFit

c. Genereren van datareeksen voor de doorlatendheidskarakteristiek tussen de bodemcompartimenten door het toepassen van de zogenaamde 'instantaneous profile' methode

d. Genereren Mualem-Van Genuchten parameters door het uitvoeren van een EindFit

Voor het uitvoeren van deze bewerkingen zijn in dit meerjarige project een filter en een rekensheet ontwikkeld in Excel. Dit is gedaan om

- de kans op fouten te verkleinen

- zoveel mogelijk bewerkingen te harmoniseren

- tussenresultaten zichtbaar te maken.

- betrouwbare afgeleide gegevens te kunnen genereren

\section{Data-filtering}

In het lab wordt met zeer korte tijdsintervallen gemeten, zodat verstoringen en temperatuurinvloeden duidelijker zichtbaar worden. Dit resulteert in erg grote databestanden. Het is daarom wenselijk om de data zoveel mogelijk te ontdoen van ruis en het aantal datapunten te reduceren voorafgaand aan verdere verwerking.

Omdat kleine schommelingen in de data (ruis, of temperatuurinvloeden) tot grote afwijkingen kunnen zorgen in de $1^{\mathrm{e}}$ lijns afgeleide data (met name de onverzadigde waterdoorlatendheid in het natte traject), is binnen dit project speciaal voor BIS en BRO een filter in Excel ontwikkeld waarmee het aantal meetrecords gereduceerd wordt tot een kleinere set waarin zich alleen de essentiële en ruisarme data bevinden. In het filter worden geen data aangepast, alleen selectief volgens een vast protocol weggelaten. In het filter wordt ook het gemiddelde volumetrische vochtgehalte van het monster bepaald. Tezamen met de ruwe meetgegevens worden deze ingelezen in het fit-programma (PreFit, Instantanuous profile, en EindFit).

In Bijlage 2 is een uitgebreidere beschrijving van het filter weergegeven. De volledige beschrijving is weergegeven in een interne memo (Heinen, et al., 2018).

\section{PreFit, Instantanuous profile, en EindFit}

Vervolgens wordt deze gereduceerde ruwe dataset (gemeten tijd, gewichten en drukhoogten) gebruikt om achtereenvolgens af te leiden:

- $1^{\mathrm{e}}$ lijns afgeleide data (fase 1 ):

- $h-\theta$ relaties (PreFit) in het midden van elke bodemlaag: op basis van de totale monstermassa en de drukhoogten in de tijd, gebruik makend van een i-modale beschrijving van de retentiecurve volgens van Genuchten (1980) ( $i=1,2$ of 3, door de gebruiker in te stellen)

- $k-h-\theta$ datareeksen op het grensvlak van de bodemlagen: $k$ op basis van de "instantaneous profile method" (Watson, 1966; Klute, 1972; Dirksen, 1991), en $h-\theta$ als gewogen gemiddelden van 2 aangrenzende lagen.

- $2^{\mathrm{e}}$ lijns afgeleide data (fase 2):

- Mualem-van Genuchten-parameters (uni-modaal): op basis van alle $1^{\mathrm{e}}$ lijns datareeksen met behulp van RETC (Van Genuchten et al., 1991; Leij et al., 1992).

Voor het uitvoeren van deze bewerkingen is binnen dit project een rekensheet ontwikkeld binnen Excel.

Het grote voordeel van de gevolgde werkwijze binnen een Excel-omgeving is dat de fitprocedure op een veel kleiner detailniveau geanalyseerd kan worden. Te denken valt daarbij aan uitbijters of 
berekende en gemeten gewichtsafnamen in de tijd. Vooral in fase 1, waarin de datareeks van de onverzadigde doorlatendheid wordt afgeleid, moet altijd kritisch door een expert worden beschouwd. Dit is met name het geval in het natte traject, waar door modellering van de gradiënt $\mathrm{d} h / \mathrm{d} t$ fouten kunnen ontstaan in de afgeleide gegevens. Bij kleine variaties in $h$ en/of $t$, tezamen met kleine afwijkingen in het meetsignaal, kan deze gradiënt voor onbedoeld grote afwijkingen in het resultaat van fase 1 leiden die in het rekensheet beter herkend kunnen worden. Het filter voorkomt al voor een groot deel de afwijkingen in het natte traject. In Bijlage 2 is een uitgebreidere beschrijving van het filter weergegeven. De volledige beschrijving is weergegeven in een interne memo (Heinen, et al., 2018).

\subsubsection{Het MvG-concept: huidige werkwijze}

De gereduceerde tijdreeksen van de drukhoogten, vochtgehalten, onverzadigde doorlatenheden en de verzadigde waterdoorlatendheden zijn gebruikt om de retentie- en onverzadigde waterdoorlatendheidskarakteristiek te bepalen. Daarbij is in dit project gebruikgemaakt van het Mualem-Van Genuchten (MvG)-model (Mualem, 1976; Van Genuchten, 1980).

\section{pF-datareeks per compartiment (PreFit, fase 1)}

In eerste instantie zijn er schattingen gedaan van het volumetrisch watergehalte op de dieptes van de tensiometers. Deze schattingen zijn gebaseerd op een aangenomen, niet werkelijke, relatie tussen drukhoogte en vochtgehalte van het monster, ofwel op een willekeurige pF-curve en de werkelijk gemeten drukhoogten in de tijd en op de verschillende diepten. De veronderstelde pF-curve is nu, anders dan de polynoombenadering in het verleden, gebaseerd op een i-modale versie van het Van Genuchten model (1980), waarbij i = 1, 2 of 3 (Durner, 1992), hetgeen door de gebruiker kan worden aangegeven. De parameters van dit model worden vervolgens iteratief aangepast, dusdanig dat er voor het gehele monster 1 generieke pF-curve geldig is. Daarbij worden de veranderingen in berekende watergehalten op de verschillende diepten van het monster gesommeerd en door iteratie van de parameterwaarden zo goed mogelijk in overeenstemming gebracht met de totale gemeten waterinhoud van het monster.

\section{K-h- $\theta$ datareeks (Instantaneous Profile Method, fase 1 )}

De in de PreFit verkregen $\theta(h)$ data worden vervolgens gebruikt om de waterbeweging tussen de 4 bodemlagen in de tijd te berekenen. Met de vergelijking van Darcy worden vervolgens voor elke set van 2 opeenvolgende tensiometers de doorlatendheden als functie van de drukhoogte berekend, resulterend in 3 datasets van 3 tensiometerparen. Deze methode is gebaseerd op de zogenaamde 'instantaneous profile method' (IPM) en is bijvoorbeeld beschreven in Peters and Durner (2008). In het natte bereik kunnen in de praktijk door kleine meetfouten $\mathrm{d} h / \mathrm{d} z$-waarden kleiner dan 1 berekend worden hetgeen resulteert in negatieve waarden van $K$, of in waarden die grote uitschieters vertonen als $\mathrm{d} h / \mathrm{d} z$ dicht bij de waarde 1 ligt. Met het filter worden deze problemen grotendeels vooraf ondervangen. Mochten er toch nog dergelijke fouten optreden, dan worden deze waarden in dit project als uitbijters beschouwd en niet meegenomen in de verdere analyse. In de literatuur wordt in deze context veelvuldig gewezen op de onzekere uitkomsten van $K$ - $h$-relaties in het natte gebied. Afhankelijk van de grondsoort is het in de praktijk daarom lastig om betrouwbare $k$ - $h$-relaties te vinden in het gebied $h=0$ tot $-50 \mathrm{~cm}$. Er zal daarom niet altijd een meting van de doorlatendheid berekend kunnen worden in het gebied $h=0$ tot $-10 \mathrm{~cm}$. Hoewel kwaliteitsstatus A dit vroeger onterecht wel vereiste (de huidige beschikbare methoden kunnen betrouwbare data in dit gebied ook niet garanderen), zijn bij het ontbreken van betrouwbare data in dit gebied de overige data wel opgenomen in BIS. Via aanvullende methoden zijn bepalingen van doorlatendheden in dit natte traject wel mogelijk, zoals via de sproeimethode of de druppel-infiltrometer, maar daar zijn in dit project nog geen middelen voor beschikbaar.

\section{Mualem-van Genuchten-fit (EindFit, fase 2)}

De aldus verkregen $\theta(h)$ en $K(h)$ datareeksen worden vervolgens gebruikt om gelijktijdig de parameters volgens het Mualem-van Genuchten model te optimaliseren met behulp van RETC (Van Genuchten et al., 1991; Leij et al., 199). Hierbij heeft de gebruiker de mogelijkheid om aanvullende meetpunten, zoals bijvoorbeeld gemeten met de hangende waterkolommethode, drukpanmethode, of een aanvullende doorlatendheidsmeting, aan de datareeks toe te voegen. Deze 
parameters worden dan ter illustratie opgeslagen in de BIS/BRO database samen met de basisdata $K-h-\theta$. De pF-curve van de EindFit kan afwijken van de pF-curve van de PreFit, omdat in de PreFit alleen naar de waterretentie is gekeken, terwijl in de EindFit gelijktijdig de waterretentie- en de doorlatendheidskarakteristiek wordt geoptimaliseerd, en omdat de EindFit geoptimaliseerd is met meer data dan alleen van de verdampingsmethode, terwijl de PreFit alleen gebaseerd is op vochtgehalten en drukhoogten uit de verdampingsmethode. Bovendien is de EindFit een 1-modale fit, terwijl de PreFit vaak een hogere modaliteit heeft.

\subsubsection{Het PDI-concept: Uitbreiding op het MvG-concept}

Voor het droge traject hebben Peters (2013) en Iden \& Durner (2014) recentelijk de volgende aanpassingen voorgesteld, bekend onder de naam PDI-concept (Peters, Durner, Iden). Hierbij wordt de waterretentiecurve geschreven als de som van een capillaire en een adsorptiebijdrage. Er wordt rekening gehouden met enerzijds de lucht-intreewaarde en met het feit dat het vochtgehalte gelijk aan nul is bij een drukhoogte die heerst in een ovendroog $\left(105^{\circ} \mathrm{C}\right)$ monster: de $\log (h)$ is dan ongeveer 6,8 à 7,0. Hiermee verdwijnt in principe het asymptotische gedrag $\left(\theta_{r}\right)$ dat standaard in de Van Genuchten-relatie zit. Voor de doorlatendheid wordt rekening gehouden met een capillaire bijdrage, een bijdrage via transport in dunne waterfilmpjes en optioneel met een bijdrage van damptransport. Hierbij wordt meestal een golvend gedrag verkregen in de relatie $K(h)$ waarbij beide grootheden op een log-schaal worden geplot. Dat stemt overeen met waarnemingen zoals verkregen met de verdampingsmethode, in tegenstelling tot de rechte lijn op log-log schaal van de Mualemvergelijking (1976) in het droge traject. Met name de beschrijving van de $K(h)$ relatie kan sterk verbeterd worden door niet de standaard Van Genuchten-Mualem-relaties te beschouwen, maar een bimodale PDI-variant, ofwel een aangevulde Van Genuchten-Mualem-relatie, te kiezen. De krommingen in de $K(h)$ data kunnen dan beter beschreven worden en de $\theta(h)$-relatie snijdt de x-as. Alleen uit oogpunt van standaardisatie en het standaardgebruik van Mualem-van Genuchtenparameters in huidige modellen, is de PDI nog niet geëffectueerd binnen BRO en BIS. In het kader van innovatie en voortschrijdend inzicht ligt het echter wel in de lijn der verwachting dat het PDI-concept in de nabije toekomst geïmplementeerd gaat worden. De voorbereidingen voor het genereren van de PDI-parameters voor BIS en BRO worden nu al gefaseerd onderzocht. 


\section{Resultaten}

In dit hoofdstuk wordt een overzicht gegeven van de resultaten. Daarbij is een indeling gehanteerd die aansluit bij de in Hoofdstuk 2 weergegeven opschalingseenheden.

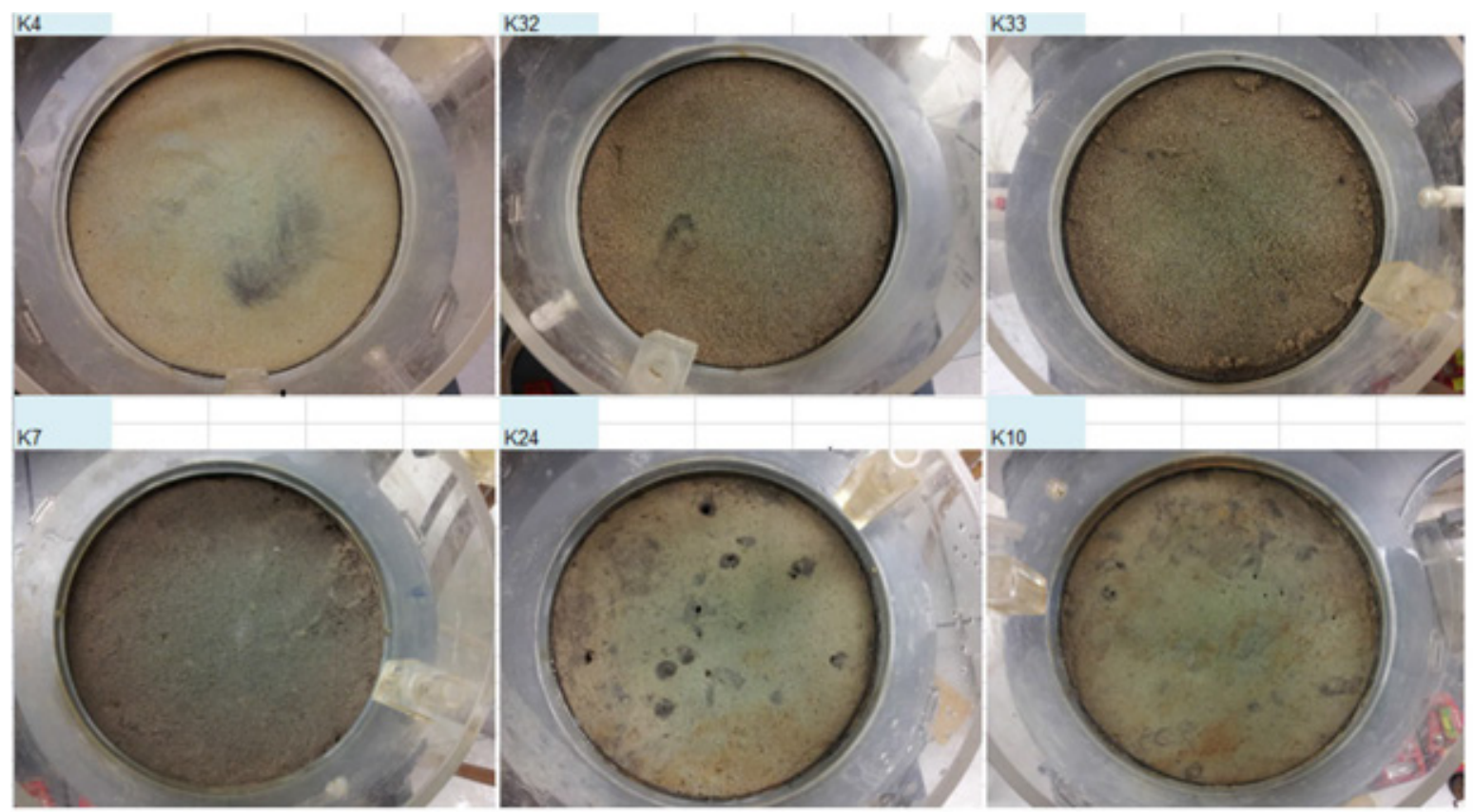

Figuur 3.1 Enkele monsters van de meetopstelling voor de verzadigde waterdoorlatendheid.

\subsection{Indeling detailresultaten}

De belangrijkste onderscheidende code is de Monster Identificatie Nummer (MIN). Met dit nummer is een koppeling te leggen tussen de verschillende tabellen. Dit nummer is ook in de BIS-database terug te vinden.

Leidend bij de presentatie van de detailresultaten in dit rapport is dat zij

A. zijn te koppelen aan één of meerdere van de 38 opschalingseenheden

B. de belangrijkste veldgegevens bevat

C. de belangrijkste hydro-fysische bodemgegevens bevat

D. aansluiting vinden bij de indeling van de vroegere Staringreeks

E. De aantallen per opschalingseenheid weergeven

Belangrijke aanvullende data die in de BIS-database zijn terug te vinden:

- de ruwe meetdata van de verdampingsmethode (tijd, massa, drukhoogten, totaal vochtgehalte)

- de hieruit (eerste) afgeleide $K-h-\theta$ volgens de prefit en aansluitend instataneous profile method

- de daaruit (tweede) afgeleide MvG-parameters, tezamen met invoerparameters en statistiek

- aanvullende veldgegevens 


\subsubsection{De 38 opschalingseenheden}

De benamingen van de 38 opschalingseenheden (Bijlage 3), zijn af te leiden met de volgende Bodemkundige Basisgegevens (Bijlage 4):

- BoKa-Codes (codes voor Bodemkundige Karakteriserings, vroeger: 'Geocodes'), Bijlage 10

- Gemeten Lutumfractie (0-2 $\mu \mathrm{m})$

- Gemeten Siltfractie $(2-50 \mu \mathrm{m})$

- Gemeten Leemfractie (0-50 $\mu \mathrm{m})$

- M50-getal (Mediaan van de (zand)fractie 50-2000 $\mu \mathrm{m}$ ): berekend uit gemeten zandfracties

- Organisch Stof gehalte (hier benaderd door het gemeten LOI = Loss on Ignition)

Bijlage 5 geeft de Afgeleide Bodemkundige Gegevens. Deze zijn direct afgeleid uit de Bodemkundige Basisgegevens van Bijlage 4.

Afgeleide bodemkundige (Bijlage 5) gegevens:

- Hoofdindeling (Moerig en Mineraal, Eolisch, Niet-Eolisch)

- Subindeling binnen Moerig en Mineraal

- Subindeling binnen Eolisch

- Subindeling binnen niet-Eolisch

- Totale benaming

\subsubsection{Belangrijkste Veldgegevens}

In Bijlage 6 worden de Belangrijkste Veldgegevens weergegeven:

- coördinaten

- monsternaam

- monsterdatum

- monsterdiepte

- standaardpuntencode

- grondwatertrap Gt

- Gemiddeld Hoogste Grondwaterstand GHG

- Gemiddeld Laagste Grondwaterstand GLG

Meer gedetailleerde gegevens, waaronder de profielbeschrijvingen, zijn terug te vinden in de database zelf.

\subsubsection{Belangrijkste hydrofysische bodemgegevens}

De textuurgegevens zijn gegeven in Bijlage 7. De M50-getallen zijn ondergebracht bij de Bodemkundige Basisgegevens. Kleine negatieve textuurfracties in de tabel duiden op fracties die lager zijn dan de aantoonbaarheidsgrens van circa $1 \%$. Resultaten van de veldschattingen en laboratoriumbepalingen kunnen uiteraard soms enigszins afwijken. De tabel gaat altijd uit van laboratoriumgegevens, tenzij deze niet beschikbaar zijn. Als het om een veldbepaling gaat is dit aangegeven. Van enkele monsters zijn de textuurgegevens (deels) onbekend. De betreffende velden zijn dan leeg gelaten.

In Bijlage 8 zijn weergegeven:

- gemeten bulkdichtheden

- gemeten verzadigde waterdoorlatendheden

- gefitte Mualem-van-Genuchten- (MvG-) parameters

- De Staringreeks bouwstenen, gebaseerd op gemeten parameters. Daar waar geen metingen aanwezig zijn, is de bouwsteen afgeleid van veldgegevens.

De Mualem-Van Genuchten-parameters zijn gegeven van de uni-modale eindfit. De verzadigde waterdoorlatendheid van de fit $\left(K_{s}^{s}\right)$ is doorgaans (veel) kleiner dan de gemeten doorlatendheid bij verzadiging $\left(K_{s}^{m}\right)$ als gevolg van de invloed van de macroporiën die in de verdampingsmethode niet, maar in de directe meting wel een grote rol spelen. In veel gevallen bleek het gewenst om een 2- of 
3-modale Van Genuchten-curve te hanteren in de prefit. Omdat de prefit alleen is gebruikt om watergehaltes te schatten bij de gemeten drukhoogten en vervolgens in de tweede stap de uiteindelijke Mualem-van Genuchten-optimalisatie (eindfit) is uitgevoerd, worden de tussenresultaten hier niet vermeld, maar zijn in de BIS-database wel opgenomen. De prefit is per bodemmonster opgeslagen in de afzonderlijke Excelbestanden en hier niet gerapporteerd.

In Bijlage 9 zijn de grafieken van de retentie- en doorlatendheidskarakteristieken gegeven.

\subsubsection{Aansluiting bij oudere Staringreeks}

Bijlage 11 geeft de indeling van de Staringreeks.

De benaming van de huidige opschalingseenheden zijn volledig gebaseerd op de die van de bodemkundige karakteriserings-methodiek (Cate, ten et al., 1995). De Staringreeks heeft in het verleden een iets andere indeling gehanteerd dan de huidige 38 opschalingseenheden van Bijlage 3 . Om toch een koppeling te kunnen maken tussen de huidige opschalingseenheden en de oudere Staringreeks zijn in Bijlage 8 de afgeleide 'bouwstenen' van de Staringreeks opgenomen.

\subsection{Aantallen monsters}

In Bijlage 12 is het aantal monsters weergegeven dat per opschalingseenheid in BIS is opgenomen.

Nieuwe gegevens, maar ook die uit oudere databases, waarvan de kwaliteit niet kan worden gegarandeerd, zijn niet in BIS/BRO opgenomen. De data in BIS 2017 bestaan daarom alleen uit gegevens met hoge kwaliteit:

1. 34 monsters van voor 1984 (nog te completeren reeks)

2. 10 monsters van voor 1984 (complete reeks, geen ruwe meetgegevens)

3. 10 monsters uit 2004 (complete reeks)

4. 137 gestoken monsters in de periode 2012-2017 (complete reeks)

5. 7 gestoken monsters in de periode 2012-2017 (incomplete reeks)

\section{Totaal: 198 monsters.}

Bovenop deze 198 kwaliteitsmonsters resteren nog

- 72 kwaliteitsmonsters van vóór 2012 waarvan geen profielbeschrijving in BIS aanwezig is. Ondanks dit hiaat, wordt de digitaal aanwezige informatie van deze 72 monsters van voldoende waarde geacht om in de nabije toekomst alsnog onder een 'dummy bodemprofiel' in BIS op te nemen. Overigens zijn van deze 72 monsters de bodemprofielen van 33 monsters via literatuur alsnog te achterhalen.

- Bovenop deze 72 monsters zijn er nog 19 kwaliteitsmonsters waarvan de digitale data onvoldoende informatie bevat voor BIS. Echter, de benodigde aanvullende gegevens zijn wel terug te vinden in de literatuur.

Het toevoegen van de aanvullende literatuurgegevens van de $33+19=52$ monsters aan BIS kost onevenredig veel tijd. Daarom is besloten om de monsters weliswaar in BIS te gaan opnemen, maar daarbij een verwijzing naar de literatuur te geven: de literatuurdata zelf wordt voorlopig niet gedigitaliseerd. In plaats van het digitaliseren van oude data wordt de voorkeur gegeven aan het bemonsteren en analyseren van nieuwe locaties.

Ad 1:

Van 34 bestaande hoogwaardige monstergegevens van voor 1984 zijn de daarvan beschikbare digitale gegevens ondergebracht in BIS en zijn gekoppeld aan bestaande profielbeschrijvingen in BIS. Het betreft hier ten minste de afgeleide doorlatendheid-drukhoogte-vochtgehalte-relaties, maar nog geen textuur, organische stofgegevens en dichtheden; deze worden in 2018 gecompleteerd. Van deze monsters zijn geen ruwe meetgegevens meer aanwezig. 
Ad 2:

Als 1), maar deze gegevens zijn al wel aangevuld met textuurgegevens, organische stofgegevens en dichtheden uit de literatuur. De MvG-fits zijn opnieuw uitgevoerd met de nieuwe software, zoals in dit rapport genoemd.

Ad 3:

Nieuwe inzichten hebben in dit project geleid tot verbeterde software (2014), waarmee afgeleide gegevens betrouwbaarder dan voorheen bepaald kunnen worden. In 2016 is dit getest op meetgegevens van 10 monsters, waarvan de afgeleide gegevens oorspronkelijk in Priapus als 'slecht' waren gekwalificeerd. De afgeleide gegevens van de opnieuw doorgerekende monsters voldoen alsnog aan de gestelde criteria en zijn samen met eventueel overige beschikbare meetgegevens en profielbeschrijvingen in BIS opgenomen.

Ad 4:

Nieuwe monsters worden genomen ter vervanging van oudere monsters van onvoldoende kwaliteit, maar ook om de spreiding in de gegevens beter te kunnen kwantificeren. Verder zijn ze in samenhang met oudere monsters geschikt om uitspraken te kunnen doen over veranderingen van de bodemgesteldheid in de tijd. Oudere monsters zijn in het verleden vaak geclusterd in bepaalde regio's genomen, omdat die voor projectdoeleinden nodig waren. De nieuwe monsters voor BIS/BRO worden genomen op locaties die een betere geografische spreiding over Nederland geven.

Ad 5:

Monsters die genomen zijn voor een ander project, en waarvoor met name de textuurdata ontbreekt.

Op basis van de huidige 198 monsters bevatten van de 38 opschalingseenheden nu 34 eenheden tenminste 3 monsters. Dit is de minimale vereiste waarde uitgaande van het feit dat vaak duplomonsters worden genomen. De streefwaarde van minimaal 2 monsterlocaties (> 3 monsters) per opschalingseenheid is daarmee gehaald, met uitzondering van de Organische eenheden 'venige klei $(1)^{\prime}$ ', 'zandig veen (0)' en 'venig zand (1)' en van de Niet-Eolische eenheden 'kleiarm silt (1)' en 'kleiig silt $(0)^{\prime}$.

Van de 36 Staringreeksbouwstenen zijn er

- 2 of meer monsters van 15 bovengronden en 15 ondergronden,

- 3 of meer monsters van 11 bovengronden en 14 ondergronden,

- 5 of meer monsters van 8 bovengronden en 11 ondergronden. 


\section{Discussie}

\subsection{Rapport en database}

Van de hydrofysische bodemdata (HF-bodemdata) die via dit project zijn gegenereerd, zijn de belangrijkste gegevens in dit rapport in tabel- en grafiekvorm opgenomen:

- ID-naam

- Afzettingsmilieu

- Textuurklassenaam

- Boven- of Ondergrond

- Coördinaten

- Monsternamedatum

- Monsterdiepte

- Standaardpuntencode (profielbeschrijving)

- Grondwatertrap

- Gemiddeld Hoogste en Gemiddeld Laagste Grondwaterstand (GHG en GLG)

- Textuurverdeling op gewichtsbasis van de minerale delen

- Droge bulkdichtheid

- Gloeiverlies (organische stof)

- Gemeten verzadigde waterdoorlatendheid

- Gemeten waterretentiekarakteristiek (gemeten WRK)

- Afgeleide waterdoorlatendheidskarakteristiek (afgeleide WDK)

- Afgeleide Mualem-Van Genuchten-parameters (afgeleide MvG)

De hydrofysische gegevens zijn in het rapport alleen opgenomen door middel van de MualemVan Genuchten-parameters en de bijbehorende grafieken, omdat de retentiekarakteristiek en onverzadigde waterdoorlatenheden eenvoudig zijn af te leiden met behulp van de vergelijkingen in Bijlage 1.

Voor uitgebreidere gegevens kan de BIS-database worden geraadpleegd. Daarin zijn nog meer gegevens opgenomen, zoals landgebruik, profielbeschrijvingen, ruwe meetdata, volumetrische vochtgehalten en waterdoorlatenheden bij verschillende drukhoogten, berekende organische stofgehalten, monsternamen van de verschillende methoden, afgeleide gegevens en meer.

\subsection{Gebruiksadvies}

\subsubsection{Aandachtspunten}

De verkregen informatie kan gebruikt worden voor het opstellen van stromingsmodellen waarin de hydrofysische bodeminformatie van een bepaalde opschalingseenheid wordt gekoppeld aan een verwante horizont dat in een bodemprofiel voorkomt. Vaak worden daarvoor afgeleide gegevens, bijvoorbeeld de Mualem-Van Genuchten-parameters, gebruikt. In de toekomst zullen deze naar verwachting vervangen worden door het PDI-parameters (Iden et al., 2014). Bij het gebruik van de gegevens in stromingsmodellen is het van belang in te zien dat:

a. De afgeleide gegevens vaak informatie bevatten in een bereik dat groter is dan dat van de oorspronkelijke meetdata. Feitelijk is er extrapolatie van de gegevens uitgevoerd die buiten het fysieke meetbereik tot onzekere resultaten kan leiden.

b. De Mualem-Van Genuchten-parameters bevatten een rekenkundig verzadigde waterdoorlatendheid die vaak veel kleiner is dan de werkelijk gemeten verzadigde waterdoorlatendheid. Dit komt omdat de verdampingsmethode over het algemeen alleen betrouwbare doorlatendheden geeft bij drukhoogten kleiner dan $-50 \mathrm{~cm}$. De MvG-fit is dan ook 
voornamelijk op die punten gebaseerd. De macroporiën in het monster, die het gedrag in het erg natte deel bepalen, kunnen in de opstelling voor de verzadigde doorlatendheid wel worden beschouwd, maar in de verdampingsmethode niet. De uni-modale MvG-vergelijkingen zijn onvoldoende in staat om dit gedrag in het natte bereik te modelleren.

c. Er onvolkomenheden kunnen zitten in de werkelijke bodemprofielopbouw ten opzichte van de profielopbouw zoals die voorkomt op de bodemkaarten. Het is bijvoorbeeld mogelijk dat er plaatselijk dunne verdichte lagen in de bodem aanwezig zijn die de snelheid van capillaire opstijging van water uit het grondwater, kunnen tegenwerken.

d. Bodemhorizonten die homogeen worden verondersteld, inhomogeen zijn en feitelijk met meerdere aparte lagen gemodelleerd moeten worden.

\subsubsection{Fuzzy-classificatie}

Gebruikers van hydrofysische bodemdata kunnen ervoor kiezen om uit te gaan van fuzzy textuurklassen, in plaats van de indeling volgens de hard gedefinieerde textuurklassen van de 38 opschalingseenheden. Als een monster nog net in een bepaalde klasse valt, wordt deze toegekend aan deze klasse, terwijl hij feitelijk ook eigenschappen bezit van de naastliggende klasse. Om hieraan tegemoet te komen, is het mogelijk om gebruik te maken van een zogenaamde 'fuzzy-classificatie'. Dit houdt in dat de werkelijk aangetroffen textuurverdeling niet wordt ingedeeld in een textuurklasse met harde grenzen, maar een gewogen deelname aan verschillende textuurklassen zal bevatten. Een hoge weging geldt dan voor de textuurklasse waarmee hij de meeste verwantschap heeft en een lagere weging voor de naastliggende klassen. De weging kan bijvoorbeeld volgens een Gauss-kromme worden toegekend.

\subsection{Raadplegen bodemfysische data in BIS}

De gegevens in BIS zijn te bereiken door direct in te loggen bij de Oracle-database en met behulp van SQL-statements de benodigde gegevens te selecteren. Toegang wordt alleen verkregen nadat er door de beheerder van de database inloggegevens zijn verstrekt.

De eenvoudigste inlogprocedure is via de command-prompt van Windows (DOS-box, te openen via Windows $\backslash$ Accessories $\backslash$ Command Prompt). Om in te loggen, moet het volgende commando worden gegeven: SQLPLUS bisuser/bisuser@geo_scomp0628.world

Hierna zal de prompt SQL> in het venster verschijnen met de vraag om de persoonlijke inloggegevens. Na het inloggen kunnen SQL-commando's worden ingetypt.

Een andere methode is het gebruik van ArcMap. Via Layers \Add Data wordt een scherm geopend met "Connection to scomp0628.sde". Selecteer de gewenste file en voeg deze toe in linker veld. Vervolgens is de inhoud te openen met de rechtermuisknop.

De identificatie van monsters wordt gegeven aan de hand van PFB_ID in tabel PFB_MONSTER.

Het zou te ver voeren om hier alle commando's te geven die gebruikt kunnen worden om gegevens uit BIS te selecteren. In het Technisch datamodel (De Groot, 2010) is hierover meer informatie beschikbaar. 


\section{$5 \quad$ Conclusies}

Dit project geeft een overzicht van het belang van een goede bodemhydrofysische datareeks, in combinatie met beschrijvende gegevens. Het heeft geresulteerd in het opnemen in BIS van

- 34 monsters van voor 1984 (nog te completeren reeks)

- 10 monsters van voor 1984 (complete reeks, geen ruwe meetgegevens)

- 10 monsters uit 2004 (complete reeks)

- 137 gestoken monsters in de periode 2012-2017 (complete reeks)

- 7 gestoken monsters in de periode 2012-2017 (incomplete reeks)

Totaal: 198 monsters.

Op basis van de huidige 181 monsters bevatten van de 38 opschalingseenheden nu 34 eenheden tenminste 3 monsters. Dit is de minimale vereiste waarde uitgaande van het feit dat vaak duplomonsters worden genomen. De streefwaarde van minimaal 2 monsterlocaties ( $>3$ monsters) per opschalingseenheid is daarmee gehaald, met uitzondering van de Organische eenheden 'zandig veen $(1)^{\prime}$ en 'venig zand (1)' en van de Niet-Eolische eenheden 'kleiarm silt (1)' en 'kleiig silt (0)'.

Van de 36 Staringreeksbouwstenen zijn er

- 2 of meer monsters van 15 bovengronden en 14 ondergronden,

- 3 of meer monsters van 12 bovengronden en 13 ondergronden,

- 5 of meer monsters van 8 bovengronden en 11 ondergronden.

De monsterlocaties zijn vanaf 2012 gericht geselecteerd aan de hand van een prioritering die door Knotters et al. (2011) is voorgesteld. Bij de opzet is uitgegaan van de Latin Hypercube Sampling, waarbij rekening gehouden wordt met het feit dat niet alle opschalingseenheden steekproefpunten bevatten ('empty domains'). Bij de bemonstering is getracht zo veel mogelijk klassen naar boven- en ondergrond, afzettingsmilieu, textuur en gehalte aan organische stof in BRO/BIS op te nemen, met ten minste twee monsters per klasse. Meerdere monsters per klasse zijn nodig om de nauwkeurigheid van geschatte gemiddelden te kunnen kwantificeren of om benaderingen, waarbij wordt geloot uit bodemhydrofysische karakteristieken voor individuele locaties, mogelijk te maken (bootstrapping). Van de nieuwe monsters zijn alle in hoofdstuk 4.1 genoemde hydrofysische bodemgegevens verzameld. Van de oude Priapus-monsters ontbreken helaas vaak een of meerdere gegevenstypen, maar zijn de waterretentie- en waterdoorlatendheids-karakteristieken altijd aanwezig.

In de nabije toekomst worden met name de nog ontbrekende opschalingseenheden en Staringreeksbouwstenen opgevuld. Daarna worden de aantallen per eenheid aangevuld tot tenminste 10 locaties per eenheid, zodat inzicht wordt verkregen in de spreiding tussen de eenheden, en het opschalen of clusteren van resultaten beter mogelijk wordt. Ook daarna is het nodig om de data te blijven vernieuwen, omdat bodems in de tijd aan (meestal langzame) veranderingen onderhevig zijn.

De drukhoogten, vochtgehalten en tijd van de verschillende meetmethoden en de verzadigde waterdoorlatendheden zijn gebruikt voor het bepalen van afgeleide hydrofysische bodemeigenschappen en de Mualem-Van Genuchten-parameters. Daarbij is in dit project een Excelrekensheet ontwikkeld dat op een veel kleiner detailniveau de fitprocedure kan analyseren, waardoor eventuele afwijkingen beter op hun waarde geschat kunnen worden. In de bijlagen is een uitgebreidere weergave van het Excelprogramma gegeven. Tevens is een filter ontwikkeld waarmee de grote databestanden, afkomstig van het laboratorium, worden gereduceerd tot een veel kleinere dataset. Kleine schommelingen in de data (ruis) zorgen normaliter voor grote afwijkingen in de afgeleide data van met name de onverzadigde waterdoorlatendheid in het natte traject. Het filter zorgt er tevens voor dat minder last wordt ondervonden van deze variaties. In het filter worden geen data aangepast, alleen selectief volgens een vast protocol weggelaten. 
Er zijn meerdere manieren mogelijk waarop hydrofysische bodemgegevens verzameld en geïnterpreteerd kunnen worden. De verschillende manieren leiden tot verschillende resultaten. Vanuit Wageningen Environmental Research WENR) wordt een eenduidige werkwijze zo veel mogelijk nagestreefd. Dit heeft geleid tot het interne document "Hydrofysische bodemgegevens: Voorkeursmethoden" (Heinen en Bakker, 2016a). 


\section{Literatuur}

Bakel, P.J.T. van, J. Huinink, H. Prak en F. van der Bolt, 2005. HELP-2005. Uitbreiding en actualisering van de HELP-tabellen ten behoeve van het WATERNOOD-instrumentarium. Utrecht, Stowa/DLG/Alterra/LNV, Stowa-rapport 2005-16.

Bakker, G., M. Heinen, J.G. Wesseling, W.J.M. de Groot, F.B.T. Assinck, E.W.J. Hummelink, 2015. Bodemfysische gegevens in BIS. Wageningen, Alterra Wageningen UR (University \& Research centre), Alterra-rapport 2613.

Bakker, G., M. Heinen, J.G. Wesseling, W.J.M. de Groot, F.B.T. Assinck, E.W.J. Hummelink, 2017. Bodemhydrofysische gegevens in BRO en BIS - Update 2016. Wageningen, Wageningen Environmental Research, Rapport 2789.

Cate, J.A.M. ten, A.F. van Holst, H. Kleijer en J. Stolp, 1995. Handleiding bodemgeografisch onderzoek; richtlijnen en voorschriften. Deel A: Bodem. Wageningen, DLO-Staring Centrum. Technisch Document 19A.

Hooghart, H., 2011. Veel gestelde vragen en antwoorden over de Basisregistratie Ondergrond, BRO.

Dirksen, C., 1991. Unsaturated hydraulic conductivity. In: K.A. Smith and C.E. Mullins (Eds.): Soil Analysis, Physical Methods. Marcel Dekker, Inc., New York, p.209-269.

Durner, W., 1992. Predicting the unsaturated hydraulic conductivity using multi-porosity water retention curves. In: M. Th. van Genuchten, F.J. Leij, and L.J. Lund (eds.), Proc. Int. Workshop, Indirect Methods for Estimating the Hydraulic Properties of Unsaturated Soils. pp. 185-202, University of California, Riverside.

E/CN, 2016. Report of the Inter-Agency and Expert Group on Sustainable Development Goal Indicators. E/CN.3/2016/2/rev.1, Annex IV.

Genuchten, M.Th. van, 1980. A Closed-form Equation for Predicting the Hydraulic Conductivity of Unsaturated Soils. Soil Sci. Soc. Am. J. 44:892-898.

Genuchten, M.Th. van, F.J. Leij and S.R. Yates, 1991. The RETC code for quantifying the hydraulic functions of unsaturated soils. USDA, US Salinity Laboratory, Riverside, CA.

Gonzalez-Morales, Luis, Yu-Chieh Hsu, Jennifer Poole, Benjamin Rae, Ian Rutherford, 2014. A World That Counts. Mobilising the data revolution for sustainable development. Report prepared at the request of the United Nations Secretary-General, by the Independent Expert Advisory Group on a Data Revolution for Sustainable Development.

Groot, H. de, 2010. Technisch Datamodel van BIS en LSK versie 7.2 en gebruik in ARCGIS. Alterra, Wageningen, $31 \mathrm{p}$.

Heinen, M. en G. Bakker, 2016a. Hydrofysische bodemgegevens: voorkeursmethoden. Interne notitie. Wageningen Environmental Research (Alterra).

Heinen, M. en G. Bakker, 2016b. Implications and Application of the Raats Superclass of Soils Equations. Wageningen, Alterra, Vadose Zone J. doi:10.2136/vzj2016.02.0012

Heinen, M. en G. Bakker, 2018. User Manual Analysing the Wind Evaporation Data. Interne notitie. Wageningen Environmental Research (WEnR).

Hemker, C.J. en R.G. de Boer, 1997. MicroFEM Version 3.60.66. Amsterdam.

Hoogewoud, J.C., J.C. Hunink, G.F. Prinsen, A.A. Veldhuizen en J. Verkaik, 2013.

Veranderingsrapportage NHI 3.0. Beschrijving van de veranderingen in versie 3.0. Deltares.

Iden, S. and W. Durner, 2014. Comment to "Simple consistent models for water retention and hydraulic conductivity in the complete moisture range" by A. Peters. Water Resources Research 50: 7530-7534.

ISO 11272 First edition, 1998. Soil quality - Determination of dry bulk density

ISO 11274 First edition, 1998. Soil quality - Determination of the waterretention characteristic Laboratory methods.

ISO 11275,2004 . Soil quality - Determination of unsaturated hydraulic conductivity and water retention characteristic- Wind's evaporation method.

ISO 11277 Second edition, 2009. Soil quality - Determination of particle size distribution in mineral soil material - Method by sieving and sedimentation. 
Klute, A., 1972. The determination of the hydraulic conductivity and diffusivity of unsaturated soils. Soil Sci. 113, 264-276.

Knotters, M., D.J. Brus, S.J.E. Verzandvoort en M. Heinen, 2011. Aanvullende bodemfysische gegevens voor BIS-Nederland. Wageningen, Alterra, Alterra-rapport 2245.

Knotters, M., F.M. van Egmond, G. Bakker, D.J.J. Walvoort, F. Brouwer, 2017. A selection of sensing techniques for mapping soil hydraulic properties, Wageningen, Alterra, WEnR Report 2853.

Leij, F.J., M.Th. van Genuchten, S.R. Yates and W.B. Russell, 1992. RETC: a computer program for analyzing soil water retention and hydraulic conductivity data. In: M.Th. van Genuchten, F.J. Leij, and L.J. Lund (eds.), Proc. Int. Workshop, Indirect Methods for Estimating the Hydraulic Properties of Unsaturated Soils. pp. 263-272, University of California, Riverside.

Mualem, Y., 1976. A new model for predicting the hydraulic conductivity of unsaturated porous media. Israel. Water Resources Research, Vol. 12, No. 3.

NEN 5753 en 5753/C1, ICS 13.080.20, 2006 en 2009. Bodem - Bepaling van het lutumgehalte en de korrelgrootteverdeling in grond en waterbodem met behulp van zeef en pipet.

NEN 5754, 1992. Bepaling van het gehalte aan organische stof in grond volgens de gloeiverliesmethode.

NEN 5789, 1991. Bepaling van de verzadigde waterdoorlatendheid.

Pastoors, M.J.H., 1992. Landelijk Grondwater Model; conceptuele modelbeschrijving (National Groundwater Model; description of model concept). RIVM-report no. 7143050004, Bilthoven, The Netherlands.

Pertassek, T., A. Peters and W. Durner, 2011. HYPROP Data Evaluation Software User's Manual, V.1.0, UMS GmbH, München, Germany.

Peters, A. and W. Durner, 2008. Simplified evaporation method for determining soil hydraulic properties. Journal of Hydrology 356: 147-162.

Peters, A., 2013. Simple consistent models for water retention and hydraulic conductivity in the complete moisture range. Water Resources Research 49: 6765-6780.Prince, K.R., O.L. Franke and T.E. Reilly, 1988. Quantitative assessment of the shallow ground-water flow system associated with Connetquot Brook, Long Island, New York: U.S. Geological Survey Water-Supply Paper 2309, $28 p$.

Ploumen, E.M.J., 2016. Nederland Ontwikkelt Duurzaam: Plan van aanpak inzake implementatie SDGs. Brief van de Minister voor Buitenlandse Handel en Ontwikkelingssamenwerking aan de Tweede Kamer. 's-Gravenhage, kst-26485-232.

Šimůnek, J., M. Sejna and M.Th. van Genuchten, 1999. The Hydrus-2D software package for simulating two-dimensional movement of water, heat, and multiple solutes in variably saturated media. Version 2.0, IGWMC - TPS - 53, International Ground Water Modeling Center, Colorado School of Mines, Golden, Colorado, 251pp.

Stolte, J., J.G. Wesseling en S. Verzandvoort-van Dijck, 2007. Kwaliteitsdocumentatie voor de verkrijging van Status A voor de gegevens van de Staringreeks zoals opgenomen in het gegevensbestand Priapus. Versie 1. Wageningen, Alterra, Alterra-rapport 1522.

Tiktak, A., F. van den Berg, J.J.T.I. Boesten, M. Leistra, A.M.A. van der Linden and D. van Kraalingen, 2000. Pesticide Emission Assessment at Regional and Local Scales: User Manual of FOCUS Pearl version 1.1.1. RIVM Report 711401008, Alterra-report 28, RIVM, Bilthoven, 142 pp.

Tiktak, A., A.M.A. van der Linden and J.J.T.I. Boesten, 2003. The GeoPEARL model. Model description, applications and manual RIVM Report 716601007/2003, RIVM, Bilthoven, 79 pp.

Tiktak, A., A.M.A. van der Linden, J.J.T.I. Boesten, R. Kruijne and D. van Kraalingen, 2004. The GeoPEARL model. Part II. User Guide and model description update. RIVM-report 716601008/2004. RIVM, Bilthoven, The Netherlands.

Verzandvoort, S.J.E., H.R.J. Vroon, J.G. Wesseling, G. Bakker, K. Oostindie, G.H. Stoffelsen, A.H. Heidema en G.B.M. Heuvelink, 2012. Naar een database van bodemhydraulische karakteristieken voor Nederland. Wageningen, Alterra, Alterra-rapport 2238.

Vogel, T., K. Huang, R. Zhang and M.Th. van Genuchten, 1996. The HYDRUS code for simulating onedimensional water flow, solute transport, and heat movement in variably-saturated media, Version 5.0, Research Report No 140, U.S. Salinity Laboratory, USDA, ARS, Riverside, CA.

Vos, J.A. de, 1997. Water flow and nutrient transport in a layered silt loam soil. Doctoral Thesis, Wageningen Agricultural University, Wageningen, The Netherlands, 287 p. 
Vries, F., F. Brouwer, Y. van Randen, R. Knaben, O. Roosenschoon, 2017. BRO - BHR ketentest - Flevo case. Evaluatie rapport Wageningen Environmental Research. Wageningen, Wageningen Environmental Research

Walsum, P.E.V. van, A.A. Veldhuizen and P. Groenendijk, 2010. SIMGRO 7.1.0, Theory and model implementation. Wageningen, Alterra, Alterra-report 913.1. 93pp.

Watson, K.K., 1966. An instantaneous profile method for determining the hydraulic conductivity of unsaturated porous materials. Water Resour. Res2, 709-715.

Wesseling, J.G., H.R.J. Vroon en F. Brouwer, 2013. Het Titanen-project. Een set software-tools voor het verwerken van veld- en labgegevens. Alterra-rapport (in voorbereiding).

Wolf, J., A.H.W. Beusen, P. Groenendijk, T. Kroon, R. Röttera and H. van Zeijts, 2003. The integrated modeling system STONE for calculating nutrient emissions from agriculture in the Netherlands. Environmental Modelling \& Software, Volume 18, Issue 7, Pages 597-617.

Wösten, J.H.M., J.H. Bannink en J. Beuving, 1987. Waterretentie- en doorlatendheidskarakteristieken van boven- en ondergronden in Nederland: de Staringreeks. Wageningen. Stiboka-rapport 1932, ICW-rapport 18.

Wösten, J.H.M., F. de Vries, J. Denneboom en A.F. van Holst, 1988. Generalisatie en bodemfysische vertaling van de bodemkaart van Nederland, 1:250000, ten behoeve van de PAWN-studie. Stiboka, Wageningen. Rapport 2055.

Wösten, J.H.M., G.J. Veerman en J. Stolte, 1994. Waterretentie- en doorlatendheidskarakteristieken van boven- en ondergronden in Nederland: de Staringreeks. Vernieuwde uitgave 1994. Wageningen, Staring Centrum-DLO, Technisch Document 18.

Wösten, J.H.M., G.J. Veerman, W.J.M de Groot en J. Stolte, 2001. Waterretentie- en doorlatendheidskarakteristieken van boven- en ondergronden in Nederland: de Staringreeks. Vernieuwde uitgave 2001. Wageningen, Wageningen UR-Alterra. Alterra-rapport 153, ISSN 1566-7197.

Wösten, J.H.M., F. de Vries, T. Hoogland, H.T.L. Massop, A.A. Veldhuizen, H.R.J. Vroon, J.G. Wesseling, J. Heijkers en A. Bolman, 2013. BOFEK2012, de nieuwe, bodemfysische schematisatie van Nederland. Wageningen, Alterra, Alterra-rapport 2387. 88 blz. 


\section{Bijlage 1 Afhankelijke beleids- en operationele modellen}

\section{Beleidsmodellen}

Beleidseffecten worden meestal gekwantificeerd met behulp van rekenmodellen. De hydrofysische (HF) bodemgegevens, die als basisinvoer voor deze modellen nodig zijn, hebben grote invloed op de uitkomsten van de modellen. Het belang van een goede HF-bodemdataset wordt daarmee onderstreept. Enkele belangrijke beleidsmodellen die in Nederland bij omgevingsgericht onderzoek gebruikt worden, zijn:

- SWAP: Soil-Water-AtmosPhere model - Eendimensionale simulatie van waterstroming en plantengroei in het systeem van bodem, water en atmosfeer (Van Dam et al., 2008).

- LGM: Landelijk Grondwater Model - Het model beschrijft de stroming van het diepere, verzadigde grondwater in een meerlagensysteem, waarbij goed doorlatende watervoerende pakketten zijn gescheiden door slecht doorlatende scheidingslagen (Pastoors, 1992).

- PEARL: Pesticide Emission At Regional and Local scales - Dit model berekent de uit- en afspoeling van gewasbeschermingsmiddelen (ook wel bestrijdingsmiddelen genoemd) naar het grond- en oppervlaktewater (Tiktak et al., 2000, 2003, 2004).

- STONE: Samen Te Ontwikkelen Nutriënten Emissie model - Dit beleidsevaluatiemodel is in samenwerking met het RIVM en RIZA ontwikkeld voor nationale beleidsevaluaties, maar kan voor verschillende schaalniveaus worden gebruikt. Het model kwantificeert de effecten van het landbouwen milieubeleid op de uitspoeling van $\mathrm{N}$ en $\mathrm{P}$ naar het grondwater en de afspoeling naar het oppervlaktewater. Het accent ligt daarbij op landbouwkundige bronnen, zoals dierlijke mest en kunstmest (Wolf et al., 2003).

- WATERNOOD en HELP-tabellen: Waternood is een methode die als leidraad wordt gebruikt voor het ontwerp en beheer van waterhuishoudkundige infrastructuur in het regionale waterbeheer. De STOWA ondersteunt deze methode via het Waternood-instrumentarium. De recentste HELP-tabellen zijn opgenomen in het instrumentarium (Van Bakel et al., 2005).

- NHI: Nationaal Hydrologisch Instrumentarium - Een geïntegreerd landsdekkend grond- en oppervlaktewatermodel van Nederland. De resultaten van het hydrologisch model worden ingezet voor landelijke beleid (Delta-beslissingen, Kader Richtlijn Water, Nitraatrichtlijn etc.) en voor operationele ondersteuning voor de waterverdeling tijdens droogte. Het is opgebouwd uit diverse gekoppelde concepten: Verzadigde zone (grondwater) - MODFLOW, Onverzadigde zone MetaSWAP, Regionaal oppervlaktewater - MOZART, Landelijk oppervlaktewater - DM (SOBEK) (Hoogewoud et al., 2013).

- SIMGRO: gedateerd acroniem voor SIMulatie van GROndwater - SIMGRO 6 combineert diverse deelprocesmodellen tot één generiek model: MetaSWAP voor de eendimensionale onverzadigde stroming, MODFLOW voor de regionale grondwaterstroming en SWQN voor het oppervlaktewater (Van Walsum et al., 2010).

\section{Operationele modellen}

Buiten de beleidsmodellen worden diverse (experimentele) modellen gebruikt op projectbasis. Ook deze modellen zijn afhankelijk van de HF-bodemgegevens als basis:

- MODFLOW - MODulair driedimensionaal grondwater FLOW model - Dit eindige differentiegrondwaterstromingsmodel, dat oorspronkelijk door de US Geological Survey is gemaakt, is modulair opgebouwd (Prince et al., 1988; Berlitz et al., 1993).

- HYDRUS-1D - Een 'public domain' model voor de eendimensionale analyse van water-, stoffen- en warmtetransport in variabele poreuze media. Vanwege het public domain-karakter wordt het wereldwijd op grote schaal toegepast (HYDRUS 2D/3D: Vogel et al., 1996).

- HYDRUS-2D/3D - De twee-/driedimensionale variant van Hydrus-1D (Šimůnek et al., 1999).

- MicroFEM - Een eindig elementen-grondwatermodel voor meerdere watervoerende lagen, geschikt voor zowel stationaire als dynamische grondwaterstroming (Hemker et al., 1997).

- FUSSIM2 - Twee-/driedimensionaal simulatiemodel voor de beschrijving van water- en zouttransport in poreuze media, de opname van water en nutriënten in de wortel, reductie van evaporatie van water aan het bodemoppervlak, oppervlakkige afstroming, (de)nitrificatie en 
bodemtemperatuur. Het model is verder gekoppeld met het organische stofmodel MOTOR (Heinen et al., 1998).

- EmMan3G - Afgeleid en versimpeld FUSSIM2-model dat bedoeld is om continue metingen van nutriënten in de bodem en de uitspoeling ervan naar het grondwater - evenals de meting van bodemvochtgehalten en drainage sturende bodemparameters in vollegronds kasteelten gedeeltelijk te vervangen.

- ZEUS - Berekent op basis van 1) hydrofysische bodemkenmerken en 2) profielgegevens, de afgeleide functionele kenmerken, zoals kritieke z-waarden, beschikbare hoeveelheden vocht in de wortelzone en ondergrond, C- en kD-waarden en berging (Wesseling et al., 2013). 


\section{Bijlage 2 Excel-programma: Filter en Fit}

Het Excelprogramma dat is gebruikt om de datareeksen van de verdampingsmethode en vervolgens de uiteindelijke Mualem-Van Genuchten-fit (MvG-fit) af te leiden, is gedurende dit project door de eerste twee auteurs ontwikkeld in 2012-2014 en is verder doorontwikkeld in de jaren daarna. In 2016 heeft dit tevens geleid tot de ontwikkeling van een filter, dat voorafgaand aan de (pre)fit wordt gebruikt om de grote hoeveelheid ruwe data van de meetopstelling te reduceren. Ook dit programma ondervindt regelmatig een update.

Aanleiding voor het ontwikkelen van nieuwe programmatuur was de wens om gedurende het fit-proces gedetailleerd inzicht te krijgen in de tussenresultaten en om onbetrouwbare meetpunten van de verdampingsmethode te kunnen verwijderen of meetpunten van aanvullende apparatuur toe te kunnen voegen en de effecten hiervan gedetailleerd te kunnen bestuderen. De aanleiding voor de ontwikkeling was dat i) kleine veranderingen in de invoer soms tot grote wijzigingen in de uitvoer leiden, ii) de uitvoer soms een onverklaarbaar uitwaaierend gedrag vertoont van de verschillende tensiometerparen, en iii) de doorlatendheid in het natte bereik soms afneemt bij een toenemende drukhoogte. De opzet via een Excel rekensheet biedt tevens kansen om op eenvoudige wijze op gebruikersniveau in- en uitvoer aan te passen, toe te voegen of te verwijderen. Bestaande software, zoals RETC (van Genuchten et al., 1991; Leij et al., 1992), Appia (Halbertsma, 1994) en HYPROP (Pertassek et al., 2011), voeren veel berekeningen op de achtergrond uit zonder dat de gebruiker tussenresultaten kan inzien. Vooral de van de ruwe verdampingsdata afgeleide datareeks van de onverzadigde doorlatendheid (fase 1) moet altijd kritisch door een expert worden beschouwd. Met name in het natte traject kunnen namelijk afwijkingen ontstaan in de afgeleide gegevens vanwege beperkingen van het onderliggende modelconcept, maar ook als gevolg van de meetnauwkeurigheid en van temperatuurinvloeden.

\section{Filter}

Datafiltering wordt uitgevoerd met een Microsoft Exceltoepassing. In deze eerste stap worden de ruwe gegevens, die rechtstreeks afkomstig zijn uit de laboratorium verdampingsmeetopstelling, gefilterd zodat ze geschikt zijn voor het fit-programma (kort: E-fits). Het filter-programma (kort: E-filter) verandert geen gegevens, maar selecteert slechts een beperkt aantal records. Over het algemeen komen er uit het lab grote databestanden van enkele duizenden records. In het lab wordt een kort meetinterval (1 minuut) gebruikt om inzicht te krijgen in de kortetermijntemperatuur-effecten en de niet-evenwichttoestanden tijdens de metingen. Pas daarna kan een gerechtvaardigde reductie van metingen worden verricht. Wanneer een groter meetinterval wordt gebruikt, worden metingen op willekeurige wijze geëlimineerd, bijvoorbeeld eenmaal bij een temperatuurstijging en een willekeurig volgend moment gedurende een temperatuurverlaging. Dit resulteert in een grotere en onverklaarbare ruis dan bij een kort meetinterval. Filteren nadat met hoge frequentie is gemeten, heeft het grote voordeel dat gebruikgemaakt kan worden van de beschikbare informatie. Dit verbetert het eindresultaat. Doel van het E-filter is om een beheersbaar bestand met 30-1000 records over te houden, met een streefwaarde van 300 records. In dit uiteindelijke bestand zijn temperatuurinvloeden zo veel mogelijk geëlimineerd. Records die niet in evenwicht blijken te zijn tijdens de initiële fase van de metingen worden verwijderd, evenals records aan het einde van de metingen op het moment dat tensiometers gaan caviteren ('doorslaan'). Verder worden records gemarkeerd als zij potentieel onbetrouwbare afgeleide resultaten genereren in E-Fits. Dat is meestal het geval tijdens kleine drukhoogteveranderingen in het meetresultaat ten opzichte van een vorig meettijdstip. Gegevens voor doorlatendheids-berekeningen zijn namelijk zeer gevoelig voor kleine $\mathrm{d} h / \mathrm{d} z$-gradiënten. De gegevens voor de $\theta(h)$-berekeningen zijn daar veel minder gevoelig voor. Als in de $k-h-\theta$ prefit en definitieve fit alleen gegevens worden gebruikt die geschikt zijn voor doorlatendheidsberekeningen, wordt waardevolle informatie over de retentiecurve weggelaten, vooral in het natte bereik. Daarom maken het E-filter en het nieuwe E-fits sinds 2016 onderscheid in deze gegevens. Dit onderscheid is in E-filter en E-Fits weergegeven door de codes 0-2. 
De ruwe data, die normaal gesproken bestaan uit een tekstbestand met vele duizenden records, worden onderworpen aan de volgende criteria:

a. De data worden gecheckt op winter- en zomertijdveranderingen en worden aangepast naar een continue tijdserie.

b. Bij elke tijdstap wordt een gemiddeld volumetrisch totaalvochtgehalte berekend op basis van de gewichten, monstervolume en stoofdroge massa.

c. Foutieve begin- en eindwaarden worden verwijderd, bijvoorbeeld punten met een toenemend gewicht of zuigspanning tijdens het op evenwicht komen voor aanvang van de werkelijke meting en punten aan het eind van de meting waar tensiometers caviteren ('doorslaan').

d. Niet goed werkende tensiometers kunnen worden uitgeschakeld voor de complete serie. Ze worden als zodanig geïndiceerd, maar niet verwijderd. Ook kunnen afzonderlijke foutieve metingen als foutief worden geïndiceerd, zoals bijvoorbeeld bij tijdelijke digitale communicatieproblemen van de meetopstelling.

e. Vervolgens worden alleen datapunten geselecteerd voor verdere analyse als deze liggen binnen een aan te passen ruis-bandbreedte. Een veelvoorkomende vorm van ruis treedt bijvoorbeeld op door schommelende temperaturen.

f. Om ten behoeve van de berekening van de punten voor onverzadigde waterdoorlatendheid te kunnen voldoen aan een voldoende grote drukverandering tussen twee meettijdstippen en tussen twee tensiometers, wordt gecheckt op een instelbare minimale gradiëntwaarde (dh/dz). In combinatie met een instelbare minimale en maximale tijdspanne tussen twee metingen worden metingen geïndiceerd als zij potentieel resulteren in onnauwkeurige waarden voor de doorlatendheid.

g. De uiteindelijke uitvoer van het E-filter, heeft hetzelfde format als die nodig is voor de invoer van het E-fits programma en bevat bij voorkeur 30-1000 records (streefwaarde 300). Elk record is gecodeerd met 0,1 , of 2, waarbij een enkele meting of een complete tensiometerreeks niet in fase 1 (PreFit + IPM) en RETC-EindFit (fase 2) gebruikt moet worden (0), of alleen gebruikt moet worden voor het bepalen van de waterretentiekarakteristiek (1), of gebruikt moet worden voor het bepalen van zowel de waterretentie- als de waterdoorlatendheidskarakteristiek (2).

\section{Invoerscherm E-fits}

In Figuur B2.1 is een indruk gegeven van het invoerscherm van de rekensheet. De gele cellen geven de mogelijkheid om de modaliteit van de PreFit aan te passen (J7), de fit-optimalisatie uit te laten voeren op basis van de gemeten monstergewichten of de gemiddelde volumetrische vochtgehalten (F17) en de weegfactor (D19) aan te passen voor het vochtgehalte bij de start van de metingen of het eind van de metingen (F19). In rij $22 \mathrm{t} / \mathrm{m} 25$ zijn aanvullende vochtgehaltemetingen toe te voegen. Lager in het invoerscherm (Figuur B2.2) zijn apart gemeten verzadigde doorlatendheden toe te voegen en is het mogelijk om de PreFit uit te laten voeren op basis van 2, 3 of 4 tensiometermeetreeksen of om individuele metingen in de fit-procedure weg te laten.

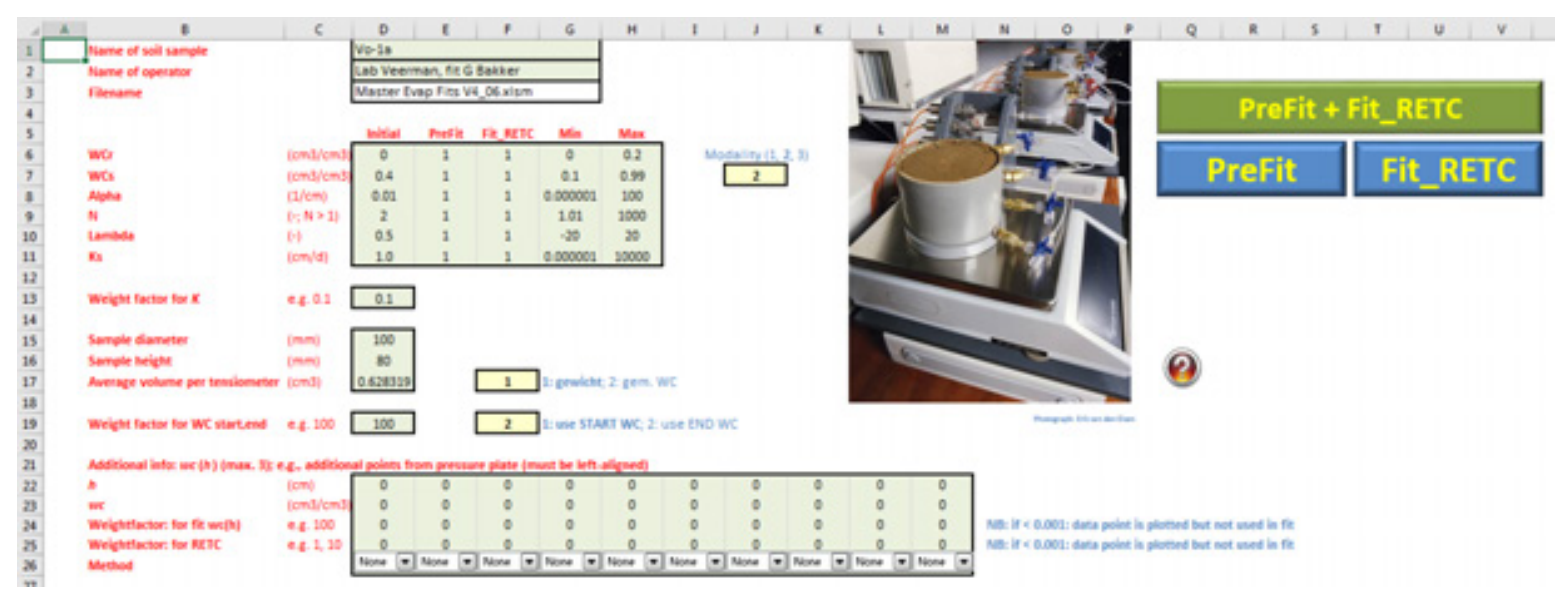

Figuur B2.1 Bovenste deel van het invoerscherm van de E-fits. 


\section{PreFit - De eerste Van Genuchten-retentiefit}

De metingen van de drukhoogten en gemiddelde volumetrische vochtgehalten van het totale monster van de verdampingsmethode worden gebruikt om de Van Genuchten-retentiecurve voor de eerste keer te fitten (PreFIT). Deze fit wordt gebruikt om vochtgehalten te berekenen in elk compartiment van het bodemmonster, ofwel op elke hoogte van de tensiometers en op elk tijdstip. Door de berekende vochtgehalten per compartiment te vermenigvuldigen met het volume van het monstercompartiment, ontstaat een berekende hoeveelheid water per compartiment.

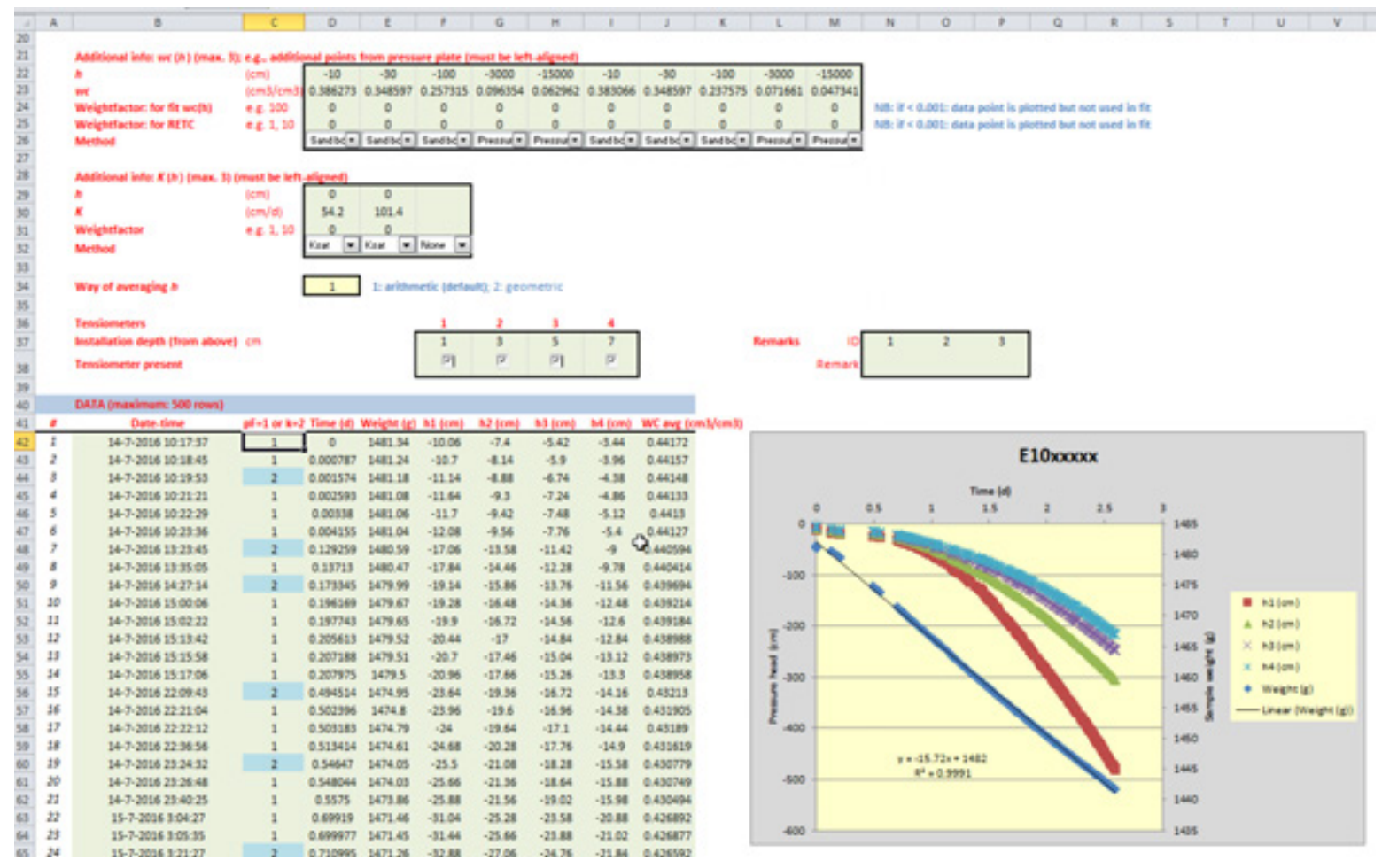

Figuur B2.2 Onderste deel van het invoerscherm van de Excelsheet.

De som van deze hoeveelheden water moet gelijk zijn aan de totale gemeten hoeveelheid water in het monster. Als hierin een afwijking zit, worden de vochtgehalten van de retentiecurve aangepast. Op deze wijze wordt de fit door iteratie geoptimaliseerd. De PreFits in dit project zijn, afhankelijk van de resultaten, uitgevoerd met een 1, 2 of 3 modale functie van Van Genuchten (1980) (cf. Durner, 1992).

De vorm van de waterretentiekarakteristiek volgens het $k$-modale Van Genuchten-model wordt bepaald met de volgende vergelijking:

$S_{e}=\sum_{i=1}^{k} w_{i}\left(\frac{1}{1+\left(\alpha_{i}|h|\right)^{n_{i}}}\right)^{m_{i}}$

waarin:

$k \quad$ totale modaliteit (hier $k=1,2$ of 3 ) is gebruikt

$S_{\mathrm{e}} \quad$ verzadigingsgraad, $S_{\mathrm{e}}=\left(\theta-\theta_{\mathrm{r}}\right) /\left(\theta_{\mathrm{s}}-\theta_{\mathrm{r}}\right)$ (dimensieloos)

$\theta \quad$ volumetrisch vochtgehalte $\left(\mathrm{L}^{3} \mathrm{~L}^{-3}\right)$ als functie van de drukhoogte $h$

$\theta_{r} \quad$ residueel vochtgehalte $\left(\mathrm{L}^{3} \mathrm{~L}^{-3}\right)$, zijnde de asymptotische waarde voor $\theta$ aan het droge uiteinde van de $\mathrm{pF}$-curve waar $\mathrm{d} \theta / \mathrm{d} h \rightarrow 0$ (dus niet per definitie bij $\theta \rightarrow 0$ )

$\theta_{s} \quad$ verzadigd vochtgehalte $\left(\mathrm{L}^{3} \mathrm{~L}^{-3}\right)$, ofwel het vochtgehalte bij $h=0$

$\alpha \quad$ vormparameter $\left(\mathrm{L}^{-1}\right)$, verschillend voor elke modaliteit $\left(\mathrm{cm}^{-1}\right)$ (voor $k=1$ gecorreleerd met $1 / h_{\text {plateau, }}$ ofwel de $h$ behorend bij het punt waar $d h / d \theta$ maximaal is) 
$n \quad$ vormparameter (-), verschillende voor elke modaliteit, stelt de steilheid van de retentiekarakteristiek voor bij kleine $\theta$; een grotere $n$ geeft een steilere grafiek bij kleine $\theta$ en daarmee een platter plateau

$m$ vormparameter, verschillende voor elke modaliteit, $m=1-1 / n$ (dimensieloos)

h drukhoogte $(\mathrm{cm})$

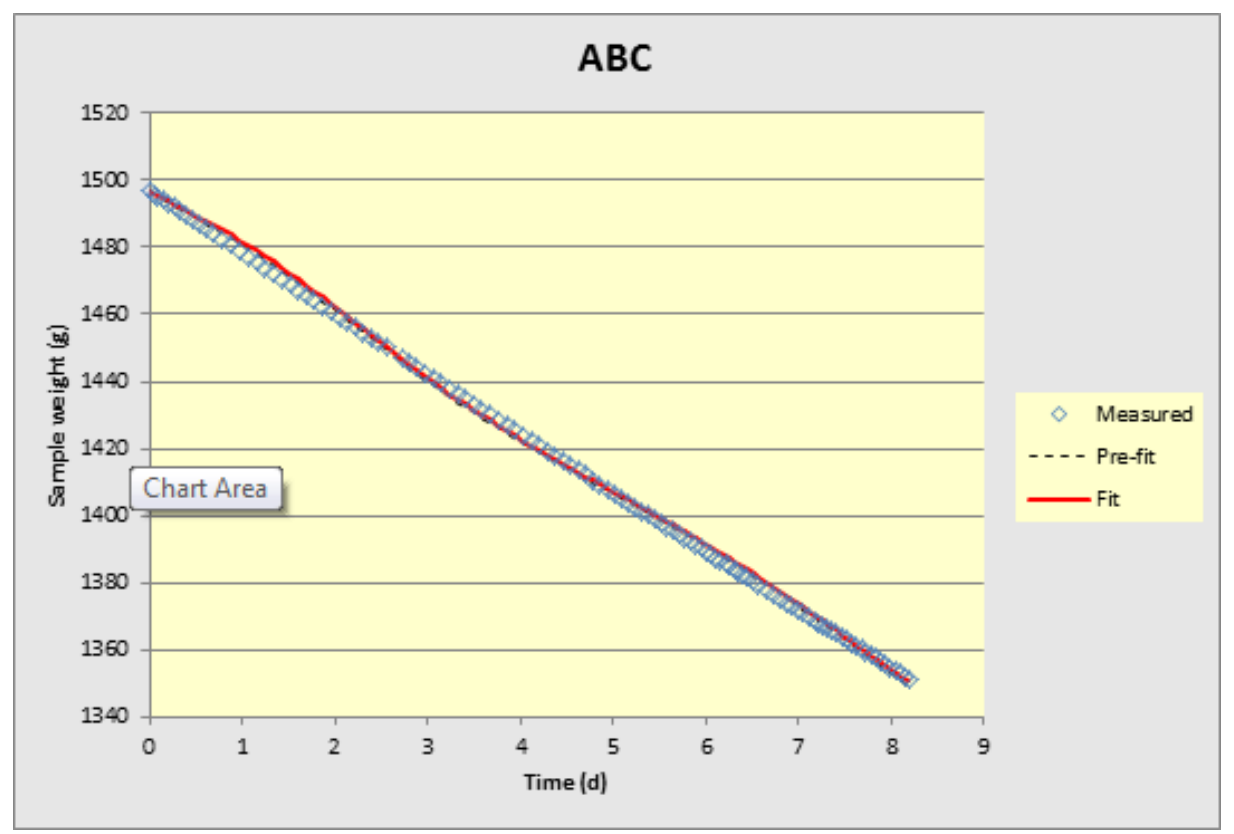

Figuur B2.3 Vergelijkende figuur van de fysiek gemeten gewichten (blauwe punten), de berekende gewichten op basis van de retentiekarakteristiek van de PreFit (zwarte stippellijn) en van de berekende EindFit volgens Mualem-Van Genuchten (rode lijn) die door het Excelprogramma worden gegenereerd.

De PreFit wordt in eerste instantie uitgevoerd met een 1-modale fit aan de metingen van de verdampingsmethode, waarbij de extra metingen van de zandbak en andere opstellingen buiten beschouwing worden gelaten. Bij onvoldoende resultaten, met name wanneer de berekende gewichtsafname onvoldoende aansluit bij de gemeten gewichtsafname, wordt de modaliteit verhoogd. Figuur B2.4 geeft een voorbeeld van het programma waarmee een dergelijke vergelijking visueel wordt gemaakt. Na de PreFit worden volgens de IPM 'instantaneous profile method' (Watson, 1966; Klute, 1972; Dirksen, 1991) de doorlatenheden op de grensvlakken tussen de 4 bodemlagen berekend De bodemlagen worden gevormd door de positie van de tensiometers: deze zitten steeds in het midden van een bodemlaag. Voor de grensvlakken tussen de bodemlagen (precies tussen de tensiometers in) geldt dat de waterflux gelijk is aan de gradiënt in drukhoogte, $\mathrm{d} h / \mathrm{d} z$, vermenigvuldigd met de doorlatendheid $K$ (wet van Darcy). De waterflux aan de bovenzijde van het monster is gelijk aan de verdamping, ofwel de afname in gewicht van het totale monster. Door stapsgewijs dieper het monster in te gaan, kan steeds de benodigde waterflux over de grenslagen van de 4 bodemlagen worden berekend per tijdseenheid, omdat uit de Prefit het vochtgehalte per tijdseenheid per bodemlaag bekend is geworden. De veranderingen in watergehalte per laag volgen uit de verschillen tussen inkomende en uitgaande waterfluxen $\left(q, \mathrm{~cm}^{3} \mathrm{~cm}^{-2} \mathrm{~d}^{-1}\right)$. Omdat de gradiënten in drukhoogte al bekend zijn, kan de doorlatenheid op de grensvlakken worden berekend. De uiteindelijk berekende doorlatendheid $K(\mathrm{~m} / \mathrm{s})$ volgt uit de vergelijking van Darcy:

$K=\frac{q}{\frac{d h}{d z}-1}$

Tevens worden voor deze grensvlakken ook waarden voor de bijbehorende drukhoogte en watergehalte berekend (middeling van de waarden in de aangrenzende bodemlagen). 
In het natte bereik kunnen in de praktijk door kleine meetfouten $\mathrm{d} h / \mathrm{d} z$-waarden resulteren in negatieve waarden van $k$ (indien $\mathrm{d} h / \mathrm{d} z<1$ ) of in waarden die grote uitschieters vertonen bij waarden van $\mathrm{d} h / \mathrm{d} z$ net groter dan 1 . Deze waarden worden in dit project als uitbijters beschouwd en niet meegenomen in de verdere analyse. Negatieve waarden voor $k$ worden in het programma automatisch verworpen door ze te markeren met een waarde van -999 (m/s). Uitbijters worden selectief door de gebruiker verwijderd door in de tussenresultaten te zoeken naar het meettijdstip waarop de uitbijter betrekking heeft en deze vervolgens in het invoerscherm uit te zetten. De uitbijters zitten normaliter in het natte meetgebied. In de literatuur wordt in deze context veelvuldig gewezen op de onzekere uitkomsten van $k$ - $h$-relaties in het natte gebied. Afhankelijk van de grondsoort is het in de praktijk daarom lastig om betrouwbare $k$ - $h$-relaties te vinden in het gebied $h=0$ tot $-50 \mathrm{~cm}$. Er zal daarom niet altijd een meting van de doorlatendheid berekend kunnen worden in het gebied $h=0$ tot $-10 \mathrm{~cm}$. Ook blijkt in de praktijk vaak dat het gebruik van een 1-modale functie onvoldoende is om het drukhoogtetraject in het natte bereik te beschrijven. Dit komt door de vaak (relatief) snelle daling van de drukhoogte in het hele natte gebied. In het half-natte gebied gaat deze weer over in een tragere daling en vervolgens in het droge gebied weer in een snellere daling.

De uiteindelijk gegenereerde drukhoogte $h$ (en daarmee ook de drukgradiënt $\mathrm{d} h / \mathrm{d} z$ ) die wordt weergegeven in de datareeksen van de retentie- en doorlatendheidskarakteristiek, is een harmonisch (optioneel: geometrisch) gemiddelde drukhoogte op het grensvlak tussen 2 opeenvolgende tensiometers en 2 opeenvolgende tijdstippen. Dit geldt ook voor het vochtgehalte $\theta$.

De aldus gegenereerde $\theta-h-K$ data zijn gebruikt in de uiteindelijke Mualem-Van Genuchten-fit.

\section{Uiteindelijke Mualem-Van Genuchten-fit}

Bij de uiteindelijke fit kunnen de metingen uit de zandbak-, drukpan- en verzadigde waterdoorlatendheidsmethode worden meegenomen in de berekening. De uiteindelijke Van Genuchten pF-curve kan afwijken van de prefit pF-curve, omdat de uiteindelijke fit geoptimaliseerd is in combinatie met de doorlatendheidsdata, terwijl de prefit alleen gebaseerd is op vochtgehalten en drukhoogten. Bovendien is de uiteindelijke fit een 1-modale fit, terwijl de prefit vaak een hogere modaliteit heeft. De vergelijkingen die gebruikt worden bij de MvG-fit zijn de vergelijkingen B.1 (met $k=1$ ) en B.3.

$K(h)=K_{s f} \frac{\left[\left(1+|\propto h|^{n}\right)^{1-1 / n}-|\propto h|^{n-1}\right]^{2}}{\left(1+|\propto h|^{n}\right)^{(1-1 / n)(L+2)}}$

waarin:

$L: \quad$ Vormparameter (-) en stelt het verloop voor van $K(h)$ bij lage $h$, ofwel bij grote zuigspanningen. Hoe groter (minder negatief) de waarde van $L$, hoe steiler de grafiek van $K(h)$.

$K_{s f}$ : Dit is de verzadigde waterdoorlatendheid van de fit. Deze waarde komt meestal niet overeen met de gemeten $K_{s m}$, die normaliter (veel) groter is. Dit komt waarschijnlijk doordat de berekende doorlatendheid bij $h=0$ geen rekening houdt met de met water gevulde macroporiën. Randvoorwaarde: $K_{s f}>0$. 


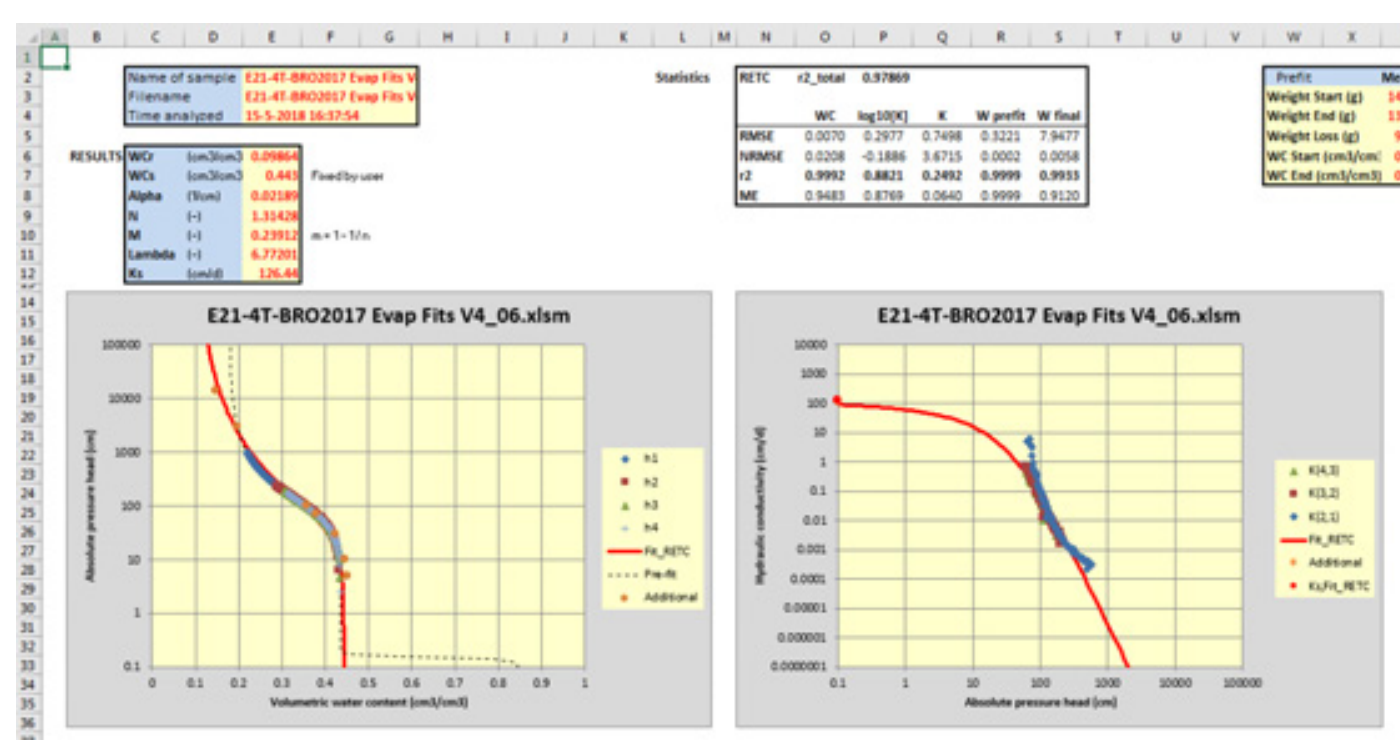

Figuur B2.4 Screendump van de 'Results'-tab van het Excelprogramma. Links de retentiekarakteristiek, rechts de doorlatendheidskarakteristiek. Verder zijn de fit-parameters en enkele statistische gegevens weergegeven. 


\section{Bijlage 3 De 38 Opschalingseenheden}

\begin{tabular}{|c|c|c|}
\hline Eenheid & OE38-Code & Omschrijving \\
\hline \multirow[t]{6}{*}{ Geologie } & $0-199$ & Moerig materiaal \\
\hline & $200-299$ & Mariene (holocene) afzettingen \\
\hline & $300-399$ & Fluviatiele afzettingen \\
\hline & $400-499$ & Eolische- en fluvio-periglaciale afzettingen \\
\hline & $500-599$ & Glaciale en fluvio-glaciale afzettingen \\
\hline & $600-699$ & Overige afzettingen \\
\hline \multirow[t]{2}{*}{ Boven- en Ondergrond } & B & Bovengrond \\
\hline & $\mathrm{O}$ & Ondergrond \\
\hline \multirow[t]{3}{*}{ Hoofdindeling } & MM & Moerig_Mineraal \\
\hline & $\mathrm{E}$ & Eolisch \\
\hline & $\mathrm{nE}$ & Niet-eolisch \\
\hline \multirow[t]{11}{*}{ Organisch } & $\mathrm{V}$ & veen \\
\hline & $\mathrm{kV}$ & kleiig veen \\
\hline & vK & venige klei \\
\hline & $\mathrm{H}$ & humusrijk \\
\hline & $\mathrm{zH}$ & zeer humeus \\
\hline & $\mathrm{mH}$ & matig humeus \\
\hline & $\mathrm{mHa}$ & matig humusarm \\
\hline & $\mathrm{zHa}$ & zeer humusarm \\
\hline & $\mathrm{uHa}$ & uiterst humusarm \\
\hline & zV & zandig veen \\
\hline & $v Z$ & venig zand \\
\hline \multirow[t]{6}{*}{ Eolisch } & laz & leemarm zand \\
\hline & $z \mid z$ & zwak lemig zand \\
\hline & $\mathrm{slz}$ & sterk lemig zand \\
\hline & $\mathrm{zs} I \mathrm{Z}$ & zeer sterk lemig zand \\
\hline & $\mathrm{zL}$ & zandige leem \\
\hline & $\mathrm{sL}$ & siltige leem \\
\hline \multirow[t]{10}{*}{ Niet-eolisch } & kaz & kleiarm zand \\
\hline & kaS & kleiarm silt \\
\hline & $k Z$ & kleiig zand \\
\hline & kS & kleiig silt \\
\hline & $z \mid z$ & zeer lichte zavel \\
\hline & $\mathrm{mlz}$ & matig lichte zavel \\
\hline & $\mathrm{zZ}$ & zware zavel \\
\hline & IK & lichte klei \\
\hline & $\mathrm{mzK}$ & matig zware klei \\
\hline & zzK & zeer zware klei \\
\hline
\end{tabular}




\section{Bijlage 4 Bodemkundige Basisgegevens}

MIN

BoKa

Fracties

Fractie

Veldschatting
Monster Identificatie Nummer;

Code Bodemkundige Karakterisering;

Lutum, Silt, Leem en M50 gebaseerd op massafracties van de granulaire delen; Organisch Stof (OS) gebaseerd op massafracties van het bulkvolume; Alleen aangegeven als de waarden betrekking hebben op veldschattingen. In de overige gevallen betreft het laboratoriumbepalingen.

\begin{tabular}{|c|c|c|c|c|c|c|c|}
\hline \multirow[t]{2}{*}{ MIN } & \multirow[t]{2}{*}{ BoKa } & \multicolumn{5}{|c|}{ Fracties $(\%)$} & \multirow{2}{*}{$\begin{array}{c}\text { Veldschatting } \\
\text { (Lu,Si, Le, M50, OS) }\end{array}$} \\
\hline & & $\begin{array}{l}\text { Lutum } \\
\text { (0-2 um) }\end{array}$ & $\begin{array}{c}\text { Silt } \\
(2-50 \text { um })\end{array}$ & $\begin{array}{l}\text { Leem } \\
\text { (0-50 um) }\end{array}$ & $\begin{array}{l}\text { M50 } \\
(\mathrm{mm})\end{array}$ & $\begin{array}{c}\text { OS } \\
(g / g)\end{array}$ & \\
\hline 50 & 510 & P.M. & P.M. & P.M. & P.M. & P.M. & \\
\hline 60 & 340 & P.M. & P.M. & P.M. & P.M. & P.M. & os \\
\hline 67 & 520 & P.M. & P.M. & P.M. & P.M. & P.M. & \\
\hline 1611 & 321 & P.M. & P.M. & P.M. & P.M. & P.M. & \\
\hline 1612 & 410 & P.M. & P.M. & P.M. & P.M. & P.M. & \\
\hline 1613 & 410 & P.M. & P.M. & P.M. & P.M. & P.M. & \\
\hline 1614 & 692 & P.M. & P.M. & P.M. & P.M. & P.M. & \\
\hline 1621 & 211 & P.M. & P.M. & P.M. & P.M. & P.M. & \\
\hline 1622 & 211 & P.M. & P.M. & P.M. & P.M. & P.M. & \\
\hline 1624 & 211 & P.M. & P.M. & P.M. & P.M. & P.M. & \\
\hline 1631 & 692 & P.M. & P.M. & P.M. & P.M. & P.M. & \\
\hline 1632 & 692 & P.M. & P.M. & P.M. & P.M. & P.M. & \\
\hline 1633 & 692 & P.M. & P.M. & P.M. & P.M. & P.M. & \\
\hline 1643 & 321 & P.M. & P.M. & P.M. & P.M. & P.M. & \\
\hline 1644 & 321 & P.M. & P.M. & P.M. & P.M. & P.M. & \\
\hline 1645 & 120 & P.M. & P.M. & P.M. & P.M. & P.M. & \\
\hline 1646 & 120 & P.M. & P.M. & P.M. & P.M. & P.M. & \\
\hline 1650 & 130 & P.M. & P.M. & P.M. & P.M. & P.M. & \\
\hline 1651 & 211 & P.M. & P.M. & P.M. & P.M. & P.M. & \\
\hline 1653 & 211 & P.M. & P.M. & P.M. & P.M. & P.M. & \\
\hline 1654 & 211 & P.M. & P.M. & P.M. & P.M. & P.M. & \\
\hline 1655 & 211 & P.M. & P.M. & P.M. & P.M. & P.M. & \\
\hline 1656 & 211 & P.M. & P.M. & P.M. & P.M. & P.M. & \\
\hline 1663 & 211 & P.M. & P.M. & P.M. & P.M. & P.M. & \\
\hline 1664 & 211 & P.M. & P.M. & P.M. & P.M. & P.M. & \\
\hline 1665 & 211 & P.M. & P.M. & P.M. & P.M. & P.M. & \\
\hline 1666 & 211 & P.M. & P.M. & P.M. & P.M. & P.M. & \\
\hline 1675 & 410 & P.M. & P.M. & P.M. & P.M. & P.M. & \\
\hline 1676 & 410 & P.M. & P.M. & P.M. & P.M. & P.M. & \\
\hline 1677 & 410 & P.M. & P.M. & P.M. & P.M. & P.M. & \\
\hline 1678 & 410 & P.M. & P.M. & P.M. & P.M. & P.M. & \\
\hline 1679 & 410 & P.M. & P.M. & P.M. & P.M. & P.M. & \\
\hline 1680 & 410 & P.M. & P.M. & P.M. & P.M. & P.M. & \\
\hline 1681 & 410 & P.M. & P.M. & P.M. & P.M. & P.M. & \\
\hline 1682 & 410 & 0.5 & 5.8 & 6.3 & 128 & 0.7 & \\
\hline 1684 & 110 & 80.1 & 9.4 & 89.5 & 739 & 41.0 & \\
\hline 1685 & 110 & 80.1 & 9.4 & 89.5 & 739 & 61.7 & \\
\hline 1686 & 120 & 90.3 & - & 94.4 & - & 81.8 & \\
\hline 1687 & 130 & - & - & - & - & 78.8 & \\
\hline 1690 & 120 & - & - & - & - & 83.6 & \\
\hline 1692 & 110 & 52.4 & 16.0 & 68.4 & 826 & 39.2 & \\
\hline 1693 & 110 & 52.4 & 16.0 & 68.4 & 826 & 39.5 & \\
\hline
\end{tabular}




\begin{tabular}{|c|c|c|c|c|c|c|c|}
\hline \multirow[t]{2}{*}{ MIN } & \multirow[t]{2}{*}{ BoKa } & \multicolumn{5}{|c|}{ Fracties $(\%)$} & \multirow{2}{*}{$\begin{array}{c}\text { Veldschatting } \\
\text { (Lu,Si, Le, M50, OS) }\end{array}$} \\
\hline & & $\begin{array}{l}\text { Lutum } \\
\text { (0-2 um) }\end{array}$ & $\begin{array}{c}\text { Silt } \\
\text { (2-50 um) }\end{array}$ & $\begin{array}{l}\text { Leem } \\
\text { (0-50 um) }\end{array}$ & $\begin{array}{l}\text { M50 } \\
(\mathrm{mm})\end{array}$ & $\begin{array}{c}\text { os } \\
(g / g)\end{array}$ & \\
\hline 1695 & 120 & - & - & - & - & 82.9 & \\
\hline 1830 & 110 & - & - & - & - & - & \\
\hline 10001 & 211 & 14.5 & 20.8 & 35.3 & 71 & 3.9 & \\
\hline 10002 & 211 & 17.3 & 23.8 & 41.1 & 77 & 4.1 & \\
\hline 10003 & 321 & 25.2 & 36.7 & 61.9 & 169 & 6.0 & \\
\hline 10004 & 321 & 26.1 & 31.5 & 57.6 & 158 & 5.8 & \\
\hline 10005 & 321 & 19.6 & 32.7 & 52.3 & 194 & 3.3 & \\
\hline 10006 & 321 & 18.5 & 27.0 & 45.5 & 193 & 2.8 & \\
\hline 10007 & 211 & 25.2 & 43.4 & 68.6 & 82 & 4.7 & \\
\hline 10008 & 211 & 26.5 & 40.7 & 67.2 & 76 & 3.9 & \\
\hline 10009 & 321 & 16.6 & 17.9 & 34.5 & 163 & 4.8 & \\
\hline 10010 & 321 & 16.4 & 20.5 & 36.9 & 173 & 4.0 & \\
\hline 10011 & 321 & 18.3 & 34.8 & 53.1 & 130 & 4.0 & \\
\hline 10012 & 321 & 17.4 & 27.0 & 44.4 & 122 & 3.8 & \\
\hline 10013 & 211 & 39.3 & 42.7 & 82.0 & 82 & 5.1 & \\
\hline 10014 & 211 & 44.0 & 39.7 & 83.7 & 72 & 4.2 & \\
\hline 10015 & 321 & 30.8 & 53.7 & 84.5 & 81 & 2.5 & \\
\hline 10016 & 321 & 26.2 & 37.9 & 64.1 & 69 & 4.9 & \\
\hline 10017 & 211 & 25.5 & 35.0 & 60.5 & 84 & 5.5 & \\
\hline 10018 & 211 & 19.5 & 28.7 & 48.2 & 81 & 3.6 & \\
\hline 10019 & 211 & 26.2 & 44.7 & 70.9 & 76 & 4.7 & \\
\hline 10020 & 211 & 31.2 & 47.4 & 78.6 & 68 & 4.3 & \\
\hline 10021 & 212 & 16.4 & 20.1 & 36.5 & 94 & 3.3 & \\
\hline 10022 & 212 & 16.8 & 19.9 & 36.7 & 84 & 2.6 & \\
\hline 10023 & 321 & 27.0 & 36.1 & 63.1 & 150 & 5.7 & \\
\hline 10024 & 321 & 25.6 & 35.5 & 61.1 & 148 & 4.2 & \\
\hline 10025 & 321 & 30.2 & 31.9 & 62.1 & 152 & 3.7 & \\
\hline 10026 & 321 & 23.5 & 23.6 & 47.1 & 90 & 4.5 & \\
\hline 10027 & 321 & 30.4 & 38.4 & 68.8 & 149 & 5.5 & \\
\hline 10028 & 321 & 30.6 & 40.4 & 71.0 & 148 & 5.3 & \\
\hline 10029 & 692 & 5.7 & 6.2 & 11.9 & 310 & 2.3 & \\
\hline 10030 & 692 & 5.4 & 6.3 & 11.7 & 313 & 2.4 & \\
\hline 10031 & 692 & 5.4 & 8.6 & 14.0 & 291 & 2.1 & \\
\hline 10032 & 692 & 5.1 & 7.8 & 12.9 & 291 & 2.1 & \\
\hline 10033 & 692 & 1.0 & 1.3 & 2.3 & 290 & 4.5 & \\
\hline 10034 & 692 & 1.9 & 0.4 & 2.3 & 287 & 4.9 & \\
\hline 10035 & 440 & 0.6 & 0.3 & 0.9 & 265 & 0.9 & \\
\hline 10036 & 440 & 0.9 & -0.2 & 0.7 & 281 & 0.8 & \\
\hline 10037 & 692 & 4.6 & 4.5 & 9.1 & 201 & 3.9 & \\
\hline 10038 & 692 & 3.9 & 5.6 & 9.5 & 198 & 3.6 & \\
\hline 10039 & 413 & 1.4 & 2.3 & 3.7 & 310 & 0.4 & \\
\hline 10040 & 413 & 0.8 & 2.9 & 3.7 & 308 & 0.5 & \\
\hline 10041 & 211 & 10.5 & 13.2 & 23.7 & 83 & 5.1 & \\
\hline 10042 & 211 & 9.9 & 10.5 & 20.4 & 83 & 4.7 & \\
\hline 10043 & 211 & 1.3 & 2.3 & 3.6 & 85 & 0.5 & \\
\hline 10044 & 211 & 1.5 & 3.2 & 4.7 & 86 & 1.1 & \\
\hline 10045 & 211 & 0.4 & 0.6 & 1.0 & 294 & 0.3 & \\
\hline 10046 & 211 & 0.3 & 0.5 & 0.8 & 292 & 0.3 & \\
\hline 10047 & 211 & 5.4 & 6.7 & 12.1 & 166 & 4.0 & \\
\hline 10048 & 211 & 5.6 & 7.3 & 12.9 & 169 & 4.1 & \\
\hline 10049 & 211 & 2.9 & 2.6 & 5.5 & 147 & 0.6 & \\
\hline 10050 & 211 & 3.3 & 3.4 & 6.7 & 147 & 0.9 & \\
\hline 10051 & 431 & 0.6 & 0.4 & 1.0 & 254 & 0.2 & \\
\hline 10052 & 431 & 0.2 & 0.2 & 0.4 & 258 & 0.2 & \\
\hline 10053 & 336 & 0.7 & 0.4 & 1.1 & 389 & 0.3 & \\
\hline 10054 & 336 & 0.3 & 0.8 & 1.1 & 347 & 0.2 & \\
\hline
\end{tabular}




\begin{tabular}{|c|c|c|c|c|c|c|c|}
\hline \multirow[t]{2}{*}{ MIN } & \multirow[t]{2}{*}{ BoKa } & \multicolumn{5}{|c|}{ Fracties ( $\%)$} & \multirow{2}{*}{$\begin{array}{c}\text { Veldschatting } \\
\text { (Lu,Si, Le, M50, OS) }\end{array}$} \\
\hline & & $\begin{array}{l}\text { Lutum } \\
\text { (0-2 um) }\end{array}$ & $\begin{array}{c}\text { Silt } \\
\text { (2-50 um) }\end{array}$ & $\begin{array}{l}\text { Leem } \\
\text { (0-50 um) }\end{array}$ & $\begin{array}{l}\text { M50 } \\
(\mathrm{mm})\end{array}$ & $\begin{array}{c}\text { OS } \\
(g / g)\end{array}$ & \\
\hline 10055 & 321 & 4.3 & 3.8 & 8.1 & 191 & 0.9 & \\
\hline 10056 & 321 & 2.9 & 3.3 & 6.2 & 211 & 1.2 & \\
\hline 10057 & 321 & 2.5 & 3.1 & 5.6 & 183 & 0.8 & \\
\hline 10058 & 321 & 1.9 & 1.2 & 3.1 & 181 & 0.7 & \\
\hline 10059 & 510 & 7.4 & 11.2 & 18.6 & 168 & 3.7 & \\
\hline 10060 & 510 & 7.3 & 10.7 & 18.0 & 167 & 3.8 & \\
\hline 10061 & 510 & 20.9 & 11.6 & 32.5 & 113 & 2.1 & \\
\hline 10062 & 510 & 19.0 & 9.7 & 28.7 & 105 & 2.3 & \\
\hline 10063 & 510 & 16.0 & 11.5 & 27.5 & 183 & 1.2 & \\
\hline 10064 & 510 & 15.2 & 11.8 & 27.0 & 183 & 1.4 & \\
\hline 10065 & 336 & 2.5 & 3.3 & 5.8 & 435 & 1.0 & \\
\hline 10066 & 336 & 1.9 & 4.3 & 6.2 & 324 & 0.8 & \\
\hline 10067 & 211 & 2.6 & 8.2 & 10.8 & 81 & 1.9 & \\
\hline 10068 & 211 & 2.2 & 7.7 & 9.9 & 82 & 2.4 & \\
\hline 10069 & 440 & 1.3 & 1.5 & 2.8 & 252 & 0.5 & \\
\hline 10070 & 440 & 1.0 & 0.7 & 1.7 & 242 & 0.6 & \\
\hline 10071 & 413 & 1.3 & 1.2 & 2.5 & 794 & 0.4 & \\
\hline 10072 & 413 & 1.0 & 1.5 & 2.5 & 828 & 0.4 & \\
\hline 10073 & 421 & 9.8 & 43.5 & 53.3 & 130 & 2.5 & \\
\hline 10074 & 421 & 9.9 & 45.4 & 55.3 & 139 & 2.8 & \\
\hline 10075 & 421 & 7.7 & 41.6 & 49.3 & 82 & 1.8 & \\
\hline 10076 & 421 & 8.4 & 45.1 & 53.5 & 107 & 1.9 & \\
\hline 10077 & 421 & 5.0 & 28.7 & 33.7 & 131 & 1.5 & \\
\hline 10078 & 421 & 7.7 & 32.4 & 40.1 & 88 & 1.8 & \\
\hline 10079 & 692 & 5.3 & 12.3 & 17.6 & 126 & 3.1 & \\
\hline 10080 & 692 & 5.2 & 13.5 & 18.7 & 124 & 3.3 & \\
\hline 10081 & 412 & 3.3 & 7.0 & 10.3 & 137 & 1.7 & \\
\hline 10082 & 412 & 3.7 & 8.0 & 11.7 & 117 & 1.2 & \\
\hline 10083 & 211 & 6.9 & 6.6 & 13.5 & 102 & 2.0 & \\
\hline 10084 & 211 & 7.1 & 6.2 & 13.3 & 103 & 2.1 & \\
\hline 10085 & 211 & 4.2 & 2.8 & 7.0 & 114 & 1.5 & \\
\hline 10086 & 211 & 5.9 & 5.7 & 11.6 & 104 & 1.6 & \\
\hline 10087 & 692 & 4.3 & 11.1 & 15.4 & 122 & 8.1 & \\
\hline 10088 & 692 & 4.4 & 11.2 & 15.6 & 128 & 8.0 & \\
\hline 10089 & 693 & 3.4 & 7.8 & 11.2 & 114 & 2.7 & \\
\hline 10090 & 693 & 3.2 & 8.8 & 12.0 & 119 & 3.7 & \\
\hline 10091 & 211 & 6.6 & 5.2 & 11.8 & 90 & 3.4 & \\
\hline 10092 & 211 & 6.6 & 5.9 & 12.5 & 90 & 2.1 & \\
\hline 10093 & 211 & 4.7 & 3.4 & 8.1 & 94 & 1.0 & \\
\hline 10094 & 211 & 6.2 & 4.1 & 10.3 & 98 & 2.3 & \\
\hline 10095 & 321 & 57.0 & 17.9 & 74.9 & 206 & 28.5 & \\
\hline 10096 & 321 & 55.1 & 16.6 & 71.7 & 201 & 28.5 & \\
\hline 10097 & 321 & 60.5 & 8.3 & 68.8 & 190 & 43.7 & \\
\hline 10098 & 321 & 65.3 & 8.3 & 73.6 & 243 & 36.1 & \\
\hline 10099 & 211 & 39.1 & 38.6 & 77.7 & 194 & 29.6 & \\
\hline 10100 & 211 & 38.8 & 38.5 & 77.3 & 189 & 28.2 & \\
\hline 10101 & 413 & 2.5 & 9.4 & 11.9 & 138 & 4.3 & \\
\hline 10102 & 413 & 2.5 & 9.4 & 11.9 & 138 & - & \\
\hline 10103 & 413 & 0.9 & 0.4 & 1.3 & 148 & 1.0 & \\
\hline 10104 & 413 & 0.9 & 0.4 & 1.3 & 148 & 1.0 & \\
\hline 10105 & 413 & 0.6 & 1.0 & 1.6 & 159 & 0.7 & \\
\hline 10106 & 413 & 0.6 & 1.0 & 1.6 & 159 & 0.7 & \\
\hline 10107 & 413 & 3.0 & 6.9 & 9.9 & 147 & 4.6 & \\
\hline 10108 & 413 & 1.2 & 0.4 & 1.6 & 144 & 1.2 & \\
\hline 10109 & 413 & 1.4 & 0.8 & 2.2 & 147 & 1.1 & \\
\hline 10110 & 413 & 1.4 & 0.8 & 2.2 & 147 & - & \\
\hline
\end{tabular}




\begin{tabular}{|c|c|c|c|c|c|c|c|}
\hline \multirow[t]{2}{*}{ MIN } & \multirow[t]{2}{*}{ BoKa } & \multicolumn{5}{|c|}{ Fracties ( $\%)$} & \multirow{2}{*}{$\begin{array}{c}\text { Veldschatting } \\
\text { (Lu,Si, Le, M50, OS) }\end{array}$} \\
\hline & & $\begin{array}{l}\text { Lutum } \\
\text { (0-2 um) }\end{array}$ & $\begin{array}{c}\text { Silt } \\
\text { (2-50 um) }\end{array}$ & $\begin{array}{l}\text { Leem } \\
\text { (0-50 um) }\end{array}$ & $\begin{array}{l}\text { M50 } \\
(\mathrm{mm})\end{array}$ & $\begin{array}{c}\text { os } \\
(g / g)\end{array}$ & \\
\hline 10111 & 321 & 24.4 & 37.0 & 61.4 & 103 & 4.5 & \\
\hline 10112 & 321 & 24.1 & 36.9 & 61.0 & 105 & 4.6 & \\
\hline 10114 & 321 & 28.4 & 34.4 & 62.8 & 110 & 3.5 & \\
\hline 10115 & 211 & 22.9 & 38.1 & 61.0 & 78 & 3.9 & \\
\hline 10116 & 211 & 21.9 & 39.0 & 60.9 & 81 & 3.7 & \\
\hline 10117 & 220 & 26.2 & 52.3 & 78.5 & 74 & 5.4 & \\
\hline 10122 & 211 & 23.5 & 27.4 & 50.9 & 100 & 4.1 & \\
\hline 10123 & 300 & 56.8 & 40.6 & 97.4 & 150 & 10.9 & \\
\hline 10124 & 300 & 58.5 & 39.5 & 98.0 & 139 & 7.8 & \\
\hline 10125 & 300 & 58.5 & 39.5 & 98.0 & 139 & 9.0 & \\
\hline 10126 & 300 & 58.5 & 39.5 & 98.0 & 139 & 8.5 & \\
\hline 10127 & 300 & 46.7 & 48.5 & 95.2 & 97 & 12.9 & \\
\hline 10128 & 300 & 46.7 & 48.5 & 95.2 & 97 & 13.9 & \\
\hline 10129 & 300 & 56.8 & 40.6 & 97.4 & 150 & 9.8 & \\
\hline 10130 & 300 & 58.5 & 39.5 & 98.0 & 139 & 6.6 & \\
\hline 10136 & 411 & 1.0 & 16.0 & 16.0 & 140.0 & 1.5 & Lu,Si, Le, M50, OS \\
\hline 10137 & 422 & 19.6 & 43.4 & 63.0 & 94 & 8.9 & \\
\hline 10138 & 412 & 1.0 & 14.0 & 14.0 & 180.0 & 2.3 & Lu,Si, Le, M50, OS \\
\hline 10139 & 693 & 1.0 & 12.0 & 12.0 & 140.0 & 16.5 & Lu,Si, Le, M50, OS \\
\hline 10140 & 132 & 34.2 & 45.1 & 79.3 & 143 & 65.1 & \\
\hline 10141 & 132 & 20.3 & 46.7 & 67.0 & 89 & 9.0 & \\
\hline 10142 & 412 & 3.0 & 25.0 & 25.0 & 140.0 & 1.7 & Lu,Si, Le, M50, OS \\
\hline 10143 & 422 & 10.0 & 65.0 & 65.0 & 90.0 & 0.3 & Lu,Si, Le, M50, OS \\
\hline 10144 & 422 & 18.7 & 63.9 & 82.6 & 61 & 0.5 & \\
\hline 10145 & 422 & 23.7 & 66.2 & 89.9 & 74 & 2.7 & \\
\hline 10146 & 421 & 17.2 & 73.0 & 90.2 & 64 & 2.6 & \\
\hline 10147 & 421 & 16.6 & 72.2 & 88.8 & 74 & 2.8 & \\
\hline 10148 & 421 & 20.0 & 69.6 & 89.6 & 60 & 0.9 & \\
\hline 10149 & 421 & 22.4 & 64.8 & 87.2 & 59 & 0.8 & \\
\hline 10150 & 412 & 11.4 & 28.1 & 39.5 & 151 & 2.4 & \\
\hline 10151 & 412 & 11.4 & 31.0 & 42.4 & 154 & 0.9 & \\
\hline 10152 & 412 & 15.8 & 24.5 & 40.3 & 141 & 4.7 & \\
\hline
\end{tabular}




\section{Bijlage 5 Afgeleide Bodemkundige Gegevens}

De in deze tabel weergegeven "Afgeleide Bodemkundige Gegevens" zijn rechtstreeks afgeleid van de "Bodemkundige Basis Gegevens".

MIN

Hoofdindeling

Moerig_Mineraal

Eolisch

Niet-Eolisch

Totale benaming
Monster Identificatie Nummer;

Afzettingsmilieu OE38-code van 'De 38 opschalingseenheden' van Bijlage 3: Moerig_Mineraal, Eolisch, of niet-Eolisch

Code volgens bijlage 'De 38 opschalingseenheden': Indeling naar OS;

Code volgens bijlage 'De 38 opschalingseenheden': Indeling naar leemfractie;

Code volgens bijlage 'De 38 opschalingseenheden': Indeling naar lutumfractie; Afgeleid van de Bodemkundige Basisgegevens.

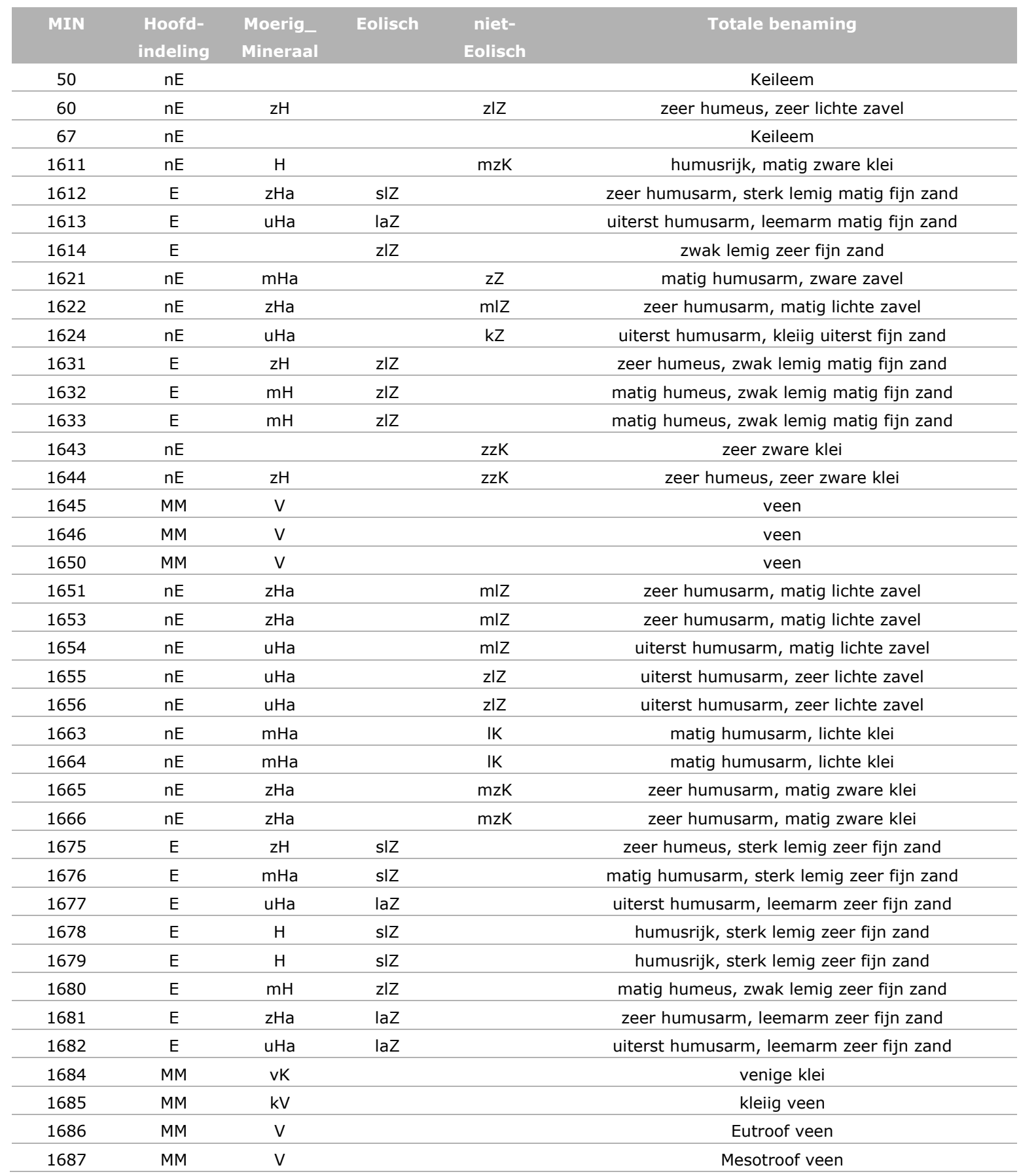




\begin{tabular}{|c|c|c|c|c|c|}
\hline MIN & $\begin{array}{l}\text { Hoofd- } \\
\text { indeling }\end{array}$ & $\begin{array}{l}\text { Moerig_ } \\
\text { Mineraal }\end{array}$ & Eolisch & $\begin{array}{c}\text { niet- } \\
\text { Eolisch }\end{array}$ & Totale benaming \\
\hline 1690 & MM & V & & & Eutroof veen \\
\hline 1692 & MM & $\mathrm{kV}$ & & & kleiig veen \\
\hline 1693 & MM & $\mathrm{kV}$ & & & kleiig veen \\
\hline 1695 & MM & $\mathrm{V}$ & & & Mesotroof veen \\
\hline 1830 & MM & $v Z$ & & kaS & Venig zand \\
\hline 10001 & $\mathrm{nE}$ & $\mathrm{mH}$ & & $\mathrm{mlZ}$ & matig humeus, matig lichte zavel \\
\hline 10002 & $\mathrm{nE}$ & $\mathrm{mH}$ & & $\mathrm{mlz}$ & matig humeus, matig lichte zavel \\
\hline 10003 & $\mathrm{nE}$ & $\mathrm{mH}$ & & IK & matig humeus, lichte klei \\
\hline 10004 & $\mathrm{nE}$ & $\mathrm{mH}$ & & IK & matig humeus, lichte klei \\
\hline 10005 & $\mathrm{nE}$ & $\mathrm{mH}$ & & $\mathrm{zZ}$ & matig humeus, zware zavel \\
\hline 10006 & $\mathrm{nE}$ & $\mathrm{mHa}$ & & $\mathrm{zZ}$ & matig humusarm, zware zavel \\
\hline 10007 & $\mathrm{nE}$ & $\mathrm{mH}$ & & IK & matig humeus, lichte klei \\
\hline 10008 & $\mathrm{nE}$ & $\mathrm{mH}$ & & IK & matig humeus, lichte klei \\
\hline 10009 & $\mathrm{nE}$ & $\mathrm{mH}$ & & $\mathrm{mlZ}$ & matig humeus, matig lichte zavel \\
\hline 10010 & $\mathrm{nE}$ & $\mathrm{mH}$ & & $\mathrm{mlZ}$ & matig humeus, matig lichte zavel \\
\hline 10011 & $\mathrm{nE}$ & $\mathrm{mH}$ & & $z Z$ & matig humeus, zware zavel \\
\hline 10012 & $\mathrm{nE}$ & $\mathrm{mH}$ & & $\mathrm{mlZ}$ & matig humeus, matig lichte zavel \\
\hline 10013 & $\mathrm{nE}$ & $\mathrm{mH}$ & & mzK & matig humeus, matig zware klei \\
\hline 10014 & $\mathrm{nE}$ & $\mathrm{mH}$ & & $\mathrm{mzK}$ & matig humeus, matig zware klei \\
\hline 10015 & $\mathrm{nE}$ & $\mathrm{mHa}$ & & $\mathrm{IK}$ & matig humusarm, lichte klei \\
\hline 10016 & $\mathrm{nE}$ & $\mathrm{mH}$ & & IK & matig humeus, lichte klei \\
\hline 10017 & $\mathrm{nE}$ & $\mathrm{mH}$ & & IK & matig humeus, lichte klei \\
\hline 10018 & $\mathrm{nE}$ & $\mathrm{mH}$ & & $z Z$ & matig humeus, zware zavel \\
\hline 10019 & $\mathrm{nE}$ & $\mathrm{mH}$ & & IK & matig humeus, lichte klei \\
\hline 10020 & $\mathrm{nE}$ & $\mathrm{mH}$ & & IK & matig humeus, lichte klei \\
\hline 10021 & $\mathrm{nE}$ & $\mathrm{mH}$ & & $\mathrm{mlZ}$ & matig humeus, matig lichte zavel \\
\hline 10022 & $\mathrm{nE}$ & $\mathrm{mHa}$ & & $\mathrm{mlz}$ & matig humusarm, matig lichte zavel \\
\hline 10023 & $\mathrm{nE}$ & $\mathrm{mH}$ & & $\mathrm{IK}$ & matig humeus, lichte klei \\
\hline 10024 & $\mathrm{nE}$ & $\mathrm{mH}$ & & $\mathrm{IK}$ & matig humeus, lichte klei \\
\hline 10025 & $\mathrm{nE}$ & $\mathrm{mH}$ & & IK & matig humeus, lichte klei \\
\hline 10026 & $\mathrm{nE}$ & $\mathrm{mH}$ & & $\mathrm{zZ}$ & matig humeus, zware zavel \\
\hline 10027 & $\mathrm{nE}$ & $\mathrm{mH}$ & & IK & matig humeus, lichte klei \\
\hline 10028 & $\mathrm{nE}$ & $\mathrm{mH}$ & & IK & matig humeus, lichte klei \\
\hline 10029 & $\mathrm{E}$ & $\mathrm{mHa}$ & $\mathrm{zlZ}$ & & matig humusarm, zwak lemig matig grof zand \\
\hline 10030 & $\mathrm{E}$ & $\mathrm{mHa}$ & $\mathrm{zlZ}$ & & matig humusarm, zwak lemig matig grof zand \\
\hline 10031 & $\mathrm{E}$ & $\mathrm{mHa}$ & $z \mid Z$ & & matig humusarm, zwak lemig matig grof zand \\
\hline 10032 & $\mathrm{E}$ & $\mathrm{mHa}$ & $z \mid Z$ & & matig humusarm, zwak lemig matig grof zand \\
\hline 10033 & $\mathrm{E}$ & $\mathrm{mH}$ & laZ & & matig humeus, leemarm matig grof zand \\
\hline 10034 & $E$ & $\mathrm{mH}$ & laZ & & matig humeus, leemarm matig grof zand \\
\hline 10035 & $E$ & $\mathrm{zHa}$ & laZ & & zeer humusarm, leemarm matig grof zand \\
\hline 10036 & $E$ & $\mathrm{zHa}$ & laZ & & zeer humusarm, leemarm matig grof zand \\
\hline 10037 & $\mathrm{E}$ & $\mathrm{mH}$ & laZ & & matig humeus, leemarm matig fijn zand \\
\hline 10038 & $E$ & $\mathrm{mH}$ & laZ & & matig humeus, leemarm matig fijn zand \\
\hline 10039 & $\mathrm{E}$ & $\mathrm{uHa}$ & laZ & & uiterst humusarm, leemarm matig grof zand \\
\hline 10040 & $E$ & $\mathrm{uHa}$ & laZ & & uiterst humusarm, leemarm matig grof zand \\
\hline 10041 & $\mathrm{nE}$ & $\mathrm{mH}$ & & $\mathrm{zlZ}$ & matig humeus, zeer lichte zavel \\
\hline 10042 & $\mathrm{nE}$ & $\mathrm{mH}$ & & $z \mid Z$ & matig humeus, zeer lichte zavel \\
\hline 10043 & $\mathrm{nE}$ & $\mathrm{uHa}$ & & kaZ & uiterst humusarm, kleiarm uiterst fijn zand \\
\hline 10044 & $\mathrm{nE}$ & $\mathrm{zHa}$ & & $\mathrm{kaZ}$ & zeer humusarm, kleiarm uiterst fijn zand \\
\hline 10045 & $\mathrm{nE}$ & $\mathrm{uHa}$ & & kaZ & uiterst humusarm, kleiarm matig grof zand \\
\hline 10046 & $\mathrm{nE}$ & $\mathrm{uHa}$ & & kaZ & uiterst humusarm, kleiarm matig grof zand \\
\hline 10047 & $\mathrm{nE}$ & $\mathrm{mH}$ & & $k Z$ & matig humeus, kleiig matig fijn zand \\
\hline 10048 & $\mathrm{nE}$ & $\mathrm{mH}$ & & $\mathrm{kZ}$ & matig humeus, kleiig matig fijn zand \\
\hline 10049 & $\mathrm{nE}$ & $\mathrm{uHa}$ & & kaZ & uiterst humusarm, kleiarm zeer fijn zand \\
\hline 10050 & $\mathrm{nE}$ & $\mathrm{zHa}$ & & kaZ & zeer humusarm, kleiarm zeer fijn zand \\
\hline 10051 & $\mathrm{E}$ & $\mathrm{uHa}$ & laZ & & uiterst humusarm, leemarm matig grof zand \\
\hline 10052 & $\mathrm{E}$ & $\mathrm{uHa}$ & laZ & & uiterst humusarm, leemarm matig grof zand \\
\hline 10053 & $\mathrm{nE}$ & $\mathrm{uHa}$ & & kaZ & uiterst humusarm, kleiarm matig grof zand \\
\hline
\end{tabular}




\begin{tabular}{|c|c|c|c|c|c|}
\hline MIN & $\begin{array}{l}\text { Hoofd- } \\
\text { indeling }\end{array}$ & $\begin{array}{l}\text { Moerig_ } \\
\text { Mineraal }\end{array}$ & Eolisch & $\begin{array}{c}\text { niet- } \\
\text { Eolisch }\end{array}$ & Totale benaming \\
\hline 10054 & $\mathrm{nE}$ & $\mathrm{uHa}$ & & kaZ & uiterst humusarm, kleiarm matig grof zand \\
\hline 10055 & $\mathrm{nE}$ & $\mathrm{zHa}$ & & kaZ & zeer humusarm, kleiarm matig fijn zand \\
\hline 10056 & $\mathrm{nE}$ & $\mathrm{zHa}$ & & kaZ & zeer humusarm, kleiarm matig grof zand \\
\hline 10057 & $\mathrm{nE}$ & $\mathrm{zHa}$ & & kaZ & zeer humusarm, kleiarm matig fijn zand \\
\hline 10058 & $\mathrm{nE}$ & $\mathrm{uHa}$ & & kaZ & uiterst humusarm, kleiarm matig fijn zand \\
\hline 10059 & $\mathrm{nE}$ & $\mathrm{mH}$ & & $\mathrm{kZ}$ & matig humeus, kleiig matig fijn zand \\
\hline 10060 & $\mathrm{nE}$ & $\mathrm{mH}$ & & $k Z$ & matig humeus, kleiig matig fijn zand \\
\hline 10061 & $\mathrm{nE}$ & $\mathrm{mHa}$ & & $z Z$ & matig humusarm, zware zavel \\
\hline 10062 & $\mathrm{nE}$ & $\mathrm{mHa}$ & & $z Z$ & matig humusarm, zware zavel \\
\hline 10063 & $\mathrm{nE}$ & $\mathrm{zHa}$ & & $\mathrm{mlZ}$ & zeer humusarm, matig lichte zavel \\
\hline 10064 & $\mathrm{nE}$ & $\mathrm{zHa}$ & & $\mathrm{mlz}$ & zeer humusarm, matig lichte zavel \\
\hline 10065 & $\mathrm{nE}$ & $\mathrm{zHa}$ & & kaZ & zeer humusarm, kleiarm zeer grof zand \\
\hline 10066 & $\mathrm{nE}$ & $\mathrm{zHa}$ & & kaZ & zeer humusarm, kleiarm matig grof zand \\
\hline 10067 & $\mathrm{nE}$ & $\mathrm{mHa}$ & & kaZ & matig humusarm, kleiarm uiterst fijn zand \\
\hline 10068 & $\mathrm{nE}$ & $\mathrm{mHa}$ & & kaZ & matig humusarm, kleiarm uiterst fijn zand \\
\hline 10069 & $E$ & $\mathrm{uHa}$ & laZ & & uiterst humusarm, leemarm matig grof zand \\
\hline 10070 & $\mathrm{E}$ & $\mathrm{uHa}$ & laZ & & uiterst humusarm, leemarm matig grof zand \\
\hline 10071 & $E$ & $\mathrm{uHa}$ & laZ & & uiterst humusarm, leemarm zeer grof zand \\
\hline 10072 & $\mathrm{E}$ & $\mathrm{uHa}$ & laZ & & uiterst humusarm, leemarm zeer grof zand \\
\hline 10073 & $\mathrm{E}$ & $\mathrm{mHa}$ & $\mathrm{zL}$ & & matig humusarm, zandige leem \\
\hline 10074 & $E$ & $\mathrm{mH}$ & $\mathrm{zL}$ & & matig humeus, zandige leem \\
\hline 10075 & $\mathrm{E}$ & $\mathrm{mHa}$ & zsIZ & & matig humusarm, zeer sterk lemig uiterst fijn zand \\
\hline 10076 & $E$ & $\mathrm{mHa}$ & zL & & matig humusarm, zandige leem \\
\hline 10077 & $\mathrm{E}$ & $\mathrm{zHa}$ & zsIZ & & zeer humusarm, zeer sterk lemig zeer fijn zand \\
\hline 10078 & $\mathrm{E}$ & $\mathrm{mHa}$ & zslZ & & matig humusarm, zeer sterk lemig uiterst fijn zand \\
\hline 10079 & $\mathrm{E}$ & $\mathrm{mH}$ & $\mathrm{slZ}$ & & matig humeus, sterk lemig zeer fijn zand \\
\hline 10080 & $\mathrm{E}$ & $\mathrm{mH}$ & slZ & & matig humeus, sterk lemig zeer fijn zand \\
\hline 10081 & $\mathrm{E}$ & $\mathrm{mHa}$ & $\mathrm{zIZ}$ & & matig humusarm, zwak lemig zeer fijn zand \\
\hline 10082 & $E$ & $\mathrm{zHa}$ & $\mathrm{zIZ}$ & & zeer humusarm, zwak lemig zeer fijn zand \\
\hline 10083 & $\mathrm{nE}$ & $\mathrm{mHa}$ & & $k Z$ & matig humusarm, kleiig uiterst fijn zand \\
\hline 10084 & $\mathrm{nE}$ & $\mathrm{mHa}$ & & $\mathrm{kZ}$ & matig humusarm, kleiig uiterst fijn zand \\
\hline 10085 & $\mathrm{nE}$ & $\mathrm{zHa}$ & & kaZ & zeer humusarm, kleiarm zeer fijn zand \\
\hline 10086 & $\mathrm{nE}$ & $\mathrm{mHa}$ & & $\mathrm{kZ}$ & matig humusarm, kleiig uiterst fijn zand \\
\hline 10087 & $\mathrm{E}$ & $\mathrm{zH}$ & $\mathrm{zlZ}$ & & zeer humeus, zwak lemig zeer fijn zand \\
\hline 10088 & $\mathrm{E}$ & $\mathrm{zH}$ & $\mathrm{zlZ}$ & & zeer humeus, zwak lemig zeer fijn zand \\
\hline 10089 & $E$ & $\mathrm{mH}$ & $\mathrm{zlZ}$ & & matig humeus, zwak lemig zeer fijn zand \\
\hline 10090 & $\mathrm{E}$ & $\mathrm{mH}$ & $z \mid Z$ & & matig humeus, zwak lemig zeer fijn zand \\
\hline 10091 & $\mathrm{nE}$ & $\mathrm{mH}$ & & $k Z$ & matig humeus, kleiig uiterst fijn zand \\
\hline 10092 & $\mathrm{nE}$ & $\mathrm{mHa}$ & & $\mathrm{kZ}$ & matig humusarm, kleiig uiterst fijn zand \\
\hline 10093 & $\mathrm{nE}$ & $\mathrm{zHa}$ & & kaZ & zeer humusarm, kleiarm uiterst fijn zand \\
\hline 10094 & $\mathrm{nE}$ & $\mathrm{mHa}$ & & kZ & matig humusarm, kleiig uiterst fijn zand \\
\hline 10095 & $\mathrm{nE}$ & & & zzK & zeer zware klei \\
\hline 10096 & $\mathrm{nE}$ & & & zzK & zeer zware klei \\
\hline 10097 & $\mathrm{nE}$ & & & zzK & zeer zware klei \\
\hline 10098 & $\mathrm{nE}$ & & & zzK & zeer zware klei \\
\hline 10099 & $\mathrm{nE}$ & & & $\mathrm{mzK}$ & matig zware klei \\
\hline 10100 & $\mathrm{nE}$ & & & $\mathrm{mzK}$ & matig zware klei \\
\hline 10101 & $\mathrm{E}$ & $\mathrm{mH}$ & $\mathrm{zlZ}$ & & matig humeus, zwak lemig zeer fijn zand \\
\hline 10102 & $E$ & & $\mathrm{zlZ}$ & & zwak lemig zeer fijn zand \\
\hline 10103 & $E$ & $\mathrm{zHa}$ & laZ & & zeer humusarm, leemarm zeer fijn zand \\
\hline 10104 & $E$ & $\mathrm{zHa}$ & laZ & & zeer humusarm, leemarm zeer fijn zand \\
\hline 10105 & $\mathrm{E}$ & $\mathrm{uHa}$ & laZ & & uiterst humusarm, leemarm matig fijn zand \\
\hline 10106 & $\mathrm{E}$ & $\mathrm{uHa}$ & laZ & & uiterst humusarm, leemarm matig fijn zand \\
\hline 10107 & $\mathrm{E}$ & $\mathrm{mH}$ & laZ & & matig humeus, leemarm zeer fijn zand \\
\hline 10108 & $\mathrm{E}$ & $\mathrm{zHa}$ & laZ & & zeer humusarm, leemarm zeer fijn zand \\
\hline 10109 & $\mathrm{E}$ & $\mathrm{zHa}$ & laZ & & zeer humusarm, leemarm zeer fijn zand \\
\hline 10110 & $\mathrm{E}$ & & laZ & & leemarm zeer fijn zand \\
\hline 10111 & $\mathrm{nE}$ & $\mathrm{mH}$ & & $\mathrm{zZ}$ & matig humeus, zware zavel \\
\hline
\end{tabular}




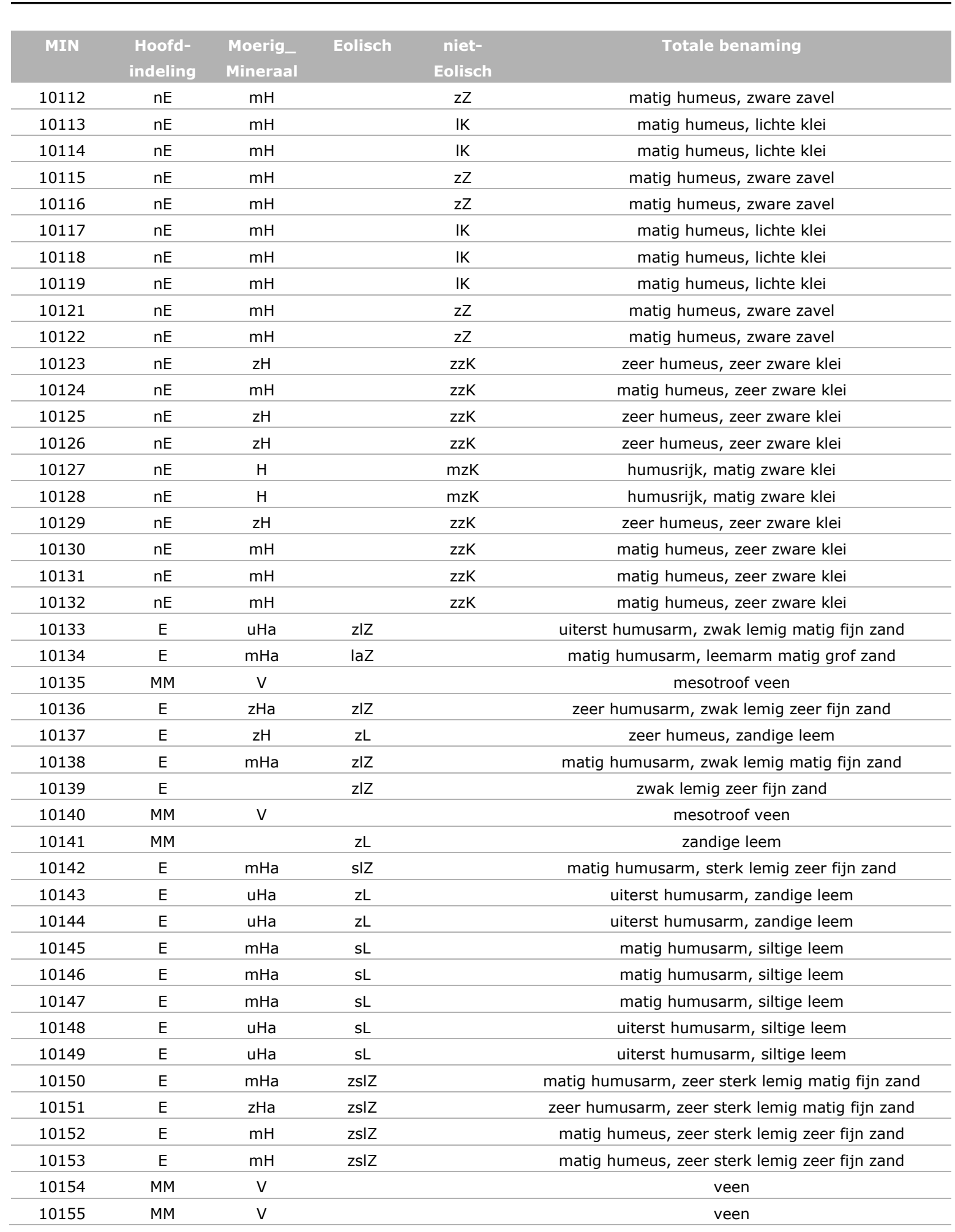




\title{
Bijlage 6 Belangrijkste Veldgegevens
}

\author{
MIN \\ Monster Naam \\ Monster Datum \\ Monster Diepte \\ $R D$-coördinaten \\ StdPntCd \\ $G t$ \\ GHG \\ Monster Identificatie Nummer; \\ Naam zoals gebruikt in veld en laboratorium; \\ Datum waarop het monster in het veld genomen is; \\ Diepte van het monster in centimeters ten opzichte van maalveld; \\ Coördinaten volgens het stelsel van de Rijksdriehoeksmeting; \\ Standaardpuntencode. \\ Grondwatertrap \\ Gemiddeld Hoogste Grondwaterstand \\ GLG \\ Gemiddeld Laagste Grondwaterstand
}

\begin{tabular}{|c|c|c|c|c|c|c|c|c|c|c|}
\hline \multirow[t]{2}{*}{ MIN } & \multirow[t]{2}{*}{$\begin{array}{l}\text { Monster } \\
\text { Naam }\end{array}$} & \multirow[t]{2}{*}{$\begin{array}{l}\text { Monster } \\
\text { Datum }\end{array}$} & \multicolumn{2}{|c|}{$\begin{array}{c}\text { Monster Diepte } \\
\text { (cm-mv) }\end{array}$} & \multicolumn{2}{|c|}{ RD-Coördinaten } & \multirow[t]{2}{*}{ StdPntCd } & \multirow[t]{2}{*}{ Gt } & \multirow[t]{2}{*}{ GHG } & \multirow[t]{2}{*}{ GLG } \\
\hline & & & van & tot & $x$ & $\mathbf{Y}$ & & & & \\
\hline 50 & L2-30b & 0-0-1985 & 30 & 38 & 263000 & 480000 & $0 K 4 p 225 c 00$ & P.M. & P.M. & P.M. \\
\hline 60 & $\mathrm{Ti}-2 \mathrm{~b}$ & $0-0-1986$ & 40 & 48 & 260000 & 491000 & 0R4p332cp50 & P.M. & P.M. & P.M. \\
\hline 67 & An-1a & $0-0-1972$ & 15 & 23 & 245000 & 563000 & $0 K 4 p 213 c 00$ & P.M. & P.M. & P.M. \\
\hline 1611 & BNK_A11 & $1-5-1979$ & 4 & 14 & 170875 & 445200 & 020433000 & P.M. & P.M. & P.M. \\
\hline 1612 & BNK_B2 & $2-5-1979$ & 35 & 45 & 170875 & 445200 & 020433000 & P.M. & P.M. & P.M. \\
\hline 1613 & BNK_C11G & $3-5-1979$ & 50 & 60 & 170875 & 445200 & 020433000 & P.M. & P.M. & P.M. \\
\hline 1614 & BRG_AP & $1-4-1979$ & 8 & 18 & 251200 & 569025 & $02 n 422000$ & P.M. & P.M. & P.M. \\
\hline 1621 & CLP_AP2 & $0-0-1984$ & 8 & 14 & 46350 & 401075 & 0M5p235a00 & P.M. & P.M. & P.M. \\
\hline 1622 & CLP_C211 & $0-0-1984$ & 30 & 36 & 46350 & 401075 & 0M5p235a00 & P.M. & P.M. & P.M. \\
\hline 1624 & CLP_C22G & $0-0-1984$ & 65 & 75 & 46350 & 401075 & 0M5p235a00 & P.M. & P.M. & P.M. \\
\hline 1631 & EDV_AANP & 0-0-1979 & 4 & 10 & 167575 & 452700 & $02 q 432000$ & P.M. & P.M. & P.M. \\
\hline 1632 & EDV_AN21 & $0-0-1979$ & 16 & 22 & 167575 & 452700 & $02 q 432000$ & P.M. & P.M. & P.M. \\
\hline 1633 & EDV_AN22 & $0-0-1979$ & 28 & 34 & 167575 & 452700 & $02 q 432000$ & P.M. & P.M. & P.M. \\
\hline 1643 & HK1_A1G & $1-7-1979$ & 2 & 12 & 120075 & 447200 & 01sb000 & P.M. & P.M. & P.M. \\
\hline 1644 & HK1_C1G & 1-7-1979 & 12 & 22 & 120075 & 447200 & $01 \mathrm{sb} 000$ & P.M. & P.M. & P.M. \\
\hline 1645 & HK1_D11 & 1-7-1979 & 40 & 50 & 120075 & 447200 & $01 \mathrm{sb} 000$ & P.M. & P.M. & P.M. \\
\hline 1646 & HK1_D12 & $1-7-1979$ & 65 & 75 & 120075 & 447200 & $01 \mathrm{sb} 000$ & P.M. & P.M. & P.M. \\
\hline 1650 & HK2_D & $1-7-1979$ & 55 & 65 & 119600 & 446850 & $01 \mathrm{sc} 000$ & P.M. & P.M. & P.M. \\
\hline 1651 & KGN_AP1 & $0-0-1984$ & 10 & 16 & 43650 & 398875 & 0M5p225a00 & P.M. & P.M. & P.M. \\
\hline 1653 & KGN_AP3 & $0-0-1984$ & 32 & 38 & 43650 & 398875 & $0 M 5 p 225 a 00$ & P.M. & P.M. & P.M. \\
\hline 1654 & KGN_C21G & $0-0-1984$ & 46 & 52 & 43650 & 398875 & 0M5p225a00 & P.M. & P.M. & P.M. \\
\hline 1655 & KGN_C22G & $0-0-1984$ & 70 & 76 & 43650 & 398875 & 0M5p225a00 & P.M. & P.M. & P.M. \\
\hline 1656 & KGN_C23G & $0-0-1984$ & 85 & 95 & 43650 & 398875 & $0 M 5 p 225 a 00$ & P.M. & P.M. & P.M. \\
\hline 1663 & KTS_AP1 & $0-0-1984$ & 6 & 12 & 49300 & 398000 & 0M5p235a00 & P.M. & P.M. & P.M. \\
\hline 1664 & KTS_AP2 & $0-0-1984$ & 20 & 26 & 49300 & 398000 & 0M5p235a00 & P.M. & P.M. & P.M. \\
\hline 1665 & KTS_C21G & $0-0-1984$ & 48 & 54 & 49300 & 398000 & $0 M 5 p 235 a 00$ & P.M. & P.M. & P.M. \\
\hline 1666 & KTS_C22G & $0-0-1984$ & 70 & 76 & 49300 & 398000 & 0M5p235a00 & P.M. & P.M. & P.M. \\
\hline 1675 & RLD_AP & $1-4-1979$ & 4 & 14 & 239975 & 553900 & $02 r 4230 \times 80$ & P.M. & P.M. & P.M. \\
\hline 1676 & RLD_B3 & $1-4-1979$ & 28 & 38 & 239975 & 553900 & $02 r 4230 \times 80$ & P.M. & P.M. & P.M. \\
\hline 1677 & RLD_C12G & $1-4-1979$ & 55 & 65 & 239975 & 553900 & $02 r 4230 \times 80$ & P.M. & P.M. & P.M. \\
\hline 1678 & SLG_AP1 & $1-4-1979$ & 2 & 12 & 275025 & 555300 & $02 r 422000$ & P.M. & P.M. & P.M. \\
\hline 1679 & SLG_AP2 & $1-4-1979$ & 4 & 14 & 275025 & 555300 & $02 r 422000$ & P.M. & P.M. & P.M. \\
\hline 1680 & SLG_B2 & $1-4-1979$ & 20 & 30 & 275025 & 555300 & $02 \mathrm{r} 422000$ & P.M. & P.M. & P.M. \\
\hline 1681 & SLG_C11 & 1-4-1979 & 40 & 50 & 275025 & 555300 & $02 \mathrm{r} 422000$ & P.M. & P.M. & P.M. \\
\hline 1682 & SLG_C12 & 1-4-1979 & 68 & 74 & 275025 & 555300 & $02 \mathrm{r} 422000$ & VI & 60 & 160 \\
\hline 1684 & ZV1_A11 & 1-7-1979 & 3 & 9 & 117250 & 461400 & $01 \mathrm{db} 000$ & II/III & 20 & 80 \\
\hline 1685 & ZV1_A12 & 1-7-1979 & 16 & 22 & 117250 & 461400 & $01 \mathrm{db} 000$ & II/III & 20 & 80 \\
\hline 1686 & ZV1_C1 & 1-7-1979 & 44 & 50 & 117250 & 461400 & $01 \mathrm{db} 000$ & II/III & 20 & 80 \\
\hline 1687 & ZV1_G & $1-7-1979$ & 70 & 80 & 117250 & 461400 & $01 \mathrm{db} 000$ & II/III & 20 & 80 \\
\hline
\end{tabular}




\begin{tabular}{|c|c|c|c|c|c|c|c|c|c|c|}
\hline \multirow[t]{2}{*}{ MIN } & \multirow[t]{2}{*}{$\begin{array}{l}\text { Monster } \\
\text { Naam }\end{array}$} & \multirow[t]{2}{*}{$\begin{array}{l}\text { Monster } \\
\text { Datum }\end{array}$} & \multicolumn{2}{|c|}{$\begin{array}{c}\text { Monster Diepte } \\
(\mathrm{cm}-\mathrm{mv})\end{array}$} & \multicolumn{2}{|c|}{ RD-Coördinaten } & \multirow[t]{2}{*}{ StdPntCd } & \multirow[t]{2}{*}{ Gt } & \multirow[t]{2}{*}{ GHG } & \multirow[t]{2}{*}{ GLG } \\
\hline & & & van & tot & $\mathrm{x}$ & $\mathbf{Y}$ & & & & \\
\hline 1690 & ZV2_C1 & $1-7-1979$ & 35 & 41 & 117350 & 461150 & $01 d c 000$ & II & 10 & 60 \\
\hline 1692 & ZV3_A11 & $1-7-1979$ & 4 & 10 & 117600 & 461125 & o1db000 & II & 10 & 70 \\
\hline 1693 & ZV3_A12 & $1-7-1979$ & 12 & 18 & 117600 & 461125 & o1db000 & II & 10 & 70 \\
\hline 1695 & ZV3_C12 & $1-7-1979$ & 40 & 46 & 117600 & 461125 & $01 \mathrm{db} 000$ & II & 10 & 70 \\
\hline 1830 & $\mathrm{Bu}-2 \mathrm{~b}$ & $0-0-1969$ & 10 & 18 & 253000 & 460000 & $02 n 431000$ & IIIa/V & 10 & 90 \\
\hline 10001 & Abb1 & $26-6-2012$ & 40 & 50 & 75248 & 427879 & M5p235a & VIIo & 90 & 140 \\
\hline 10002 & Abb1 & $26-6-2012$ & 40 & 50 & 75248 & 427879 & M5p235a & VIIo & 90 & 140 \\
\hline 10003 & Bun11 & $6-6-2012$ & 5 & 15 & 144560 & 452490 & $\mathrm{R} 5 \times 315 \mathrm{c}$ & VIo & 70 & 150 \\
\hline 10004 & Bun11 & $6-6-2012$ & 5 & 15 & 144560 & 452490 & $\mathrm{R} 5 \times 315 \mathrm{c}$ & VIo & 70 & 150 \\
\hline 10005 & Bun12 & $6-6-2012$ & 45 & 55 & 144560 & 452490 & $\mathrm{R} 5 \times 315 \mathrm{c}$ & VIo & 70 & 150 \\
\hline 10006 & Bun12 & $6-6-2012$ & 45 & 55 & 144560 & 452490 & $\mathrm{R} 5 \times 315 \mathrm{c}$ & VIo & 70 & 150 \\
\hline 10007 & CK1 & $10-5-2012$ & 5 & 15 & 171402 & 504777 & M5p315a & VIIo & 90 & 150 \\
\hline 10008 & CK1 & $10-5-2012$ & 5 & 15 & 171402 & 504777 & M5p315a & VIIo & 90 & 150 \\
\hline 10009 & Cot1 & $23-5-2012$ & 10 & 20 & 148307 & 446398 & R5x235a & VIId & 100 & 200 \\
\hline 10010 & Cot1 & $23-5-2012$ & 10 & 20 & 148307 & 446398 & $\mathrm{R} 5 \times 235 \mathrm{a}$ & VIId & 100 & 200 \\
\hline 10011 & Gor1 & $13-6-2012$ & 40 & 50 & 208683 & 468149 & $\mathrm{R} 5 \times 232 \mathrm{a}$ & VIIId & 160 & 260 \\
\hline 10012 & Gor1 & $13-6-2012$ & 40 & 50 & 208683 & 468149 & $\mathrm{R} 5 \times 232 \mathrm{a}$ & VIIId & 160 & 260 \\
\hline 10013 & Hoo1 & $13-6-2012$ & 60 & 70 & 125225 & 527770 & M5p235c/H & VIo & 60 & 160 \\
\hline 10014 & Hoo1 & $13-6-2012$ & 60 & 70 & 125225 & 527770 & M5p235c/H & VIo & 60 & 160 \\
\hline 10015 & Pan1 & $16-5-2012$ & 30 & 40 & 200220 & 433880 & R5×315a & VIo & 60 & 160 \\
\hline 10016 & Pan1 & $16-5-2012$ & 30 & 40 & 200220 & 433880 & R5x315a & VIo & 60 & 160 \\
\hline 10017 & Pon1 & $13-6-2012$ & 50 & 60 & 132749 & 535189 & M5p235a & VIIo & 90 & 140 \\
\hline 10018 & Pon1 & $13-6-2012$ & 50 & 60 & 132749 & 535189 & M5p235a & VIIo & 90 & 140 \\
\hline 10019 & Poo1 & $26-6-2012$ & 35 & 45 & 69226 & 396699 & M5m311c & VIo & 50 & 120 \\
\hline 10020 & Poo1 & $26-6-2012$ & 35 & 45 & 69226 & 396699 & M5m311c & VIo & 50 & 120 \\
\hline 10021 & PPO1 & $10-5-2012$ & 5 & 15 & 166645 & 505600 & M5p235a & VIIo & 90 & 150 \\
\hline 10022 & PPO1 & $10-5-2012$ & 5 & 15 & 166645 & 505600 & M5p235a & VIIo & 90 & 150 \\
\hline 10023 & Ran11 & $16-5-2012$ & 10 & 20 & 176290 & 439670 & R5p235cp10 & VIo & 70 & 170 \\
\hline 10024 & Ran11 & $16-5-2012$ & 10 & 20 & 176290 & 439670 & R5p235cp10 & VIo & 70 & 170 \\
\hline 10025 & Ran12 & $16-5-2012$ & 40 & 50 & 176290 & 439670 & R5p235cp10 & VIo & 70 & 170 \\
\hline 10026 & Ran12 & $16-5-2012$ & 40 & 50 & 176290 & 439670 & R5p235cp10 & VIo & 70 & 170 \\
\hline 10027 & Voo1 & $17-10-2012$ & 5 & 15 & 207750 & 465610 & R5p315b & VId & 70 & 190 \\
\hline 10028 & Voo1 & $17-10-2012$ & 5 & 15 & 207750 & 465610 & R5p315b & VId & 70 & 190 \\
\hline 10029 & Rhe1 & 3-6-2013 & 5 & 15 & 169620 & 441340 & $4 s 512$ & VIIId & 300 & 400 \\
\hline 10030 & Rhe1 & $3-6-2013$ & 5 & 15 & 169620 & 441340 & $4 s 512$ & VIIId & 300 & 400 \\
\hline 10031 & Zel1 & $10-6-2013$ & 25 & 35 & 198720 & 412570 & $4 r 513$ & VIId & 120 & 200 \\
\hline 10032 & Zel1 & $10-6-2013$ & 25 & 35 & 198720 & 412570 & $4 r 513$ & VIId & 120 & 200 \\
\hline 10033 & Wel11 & $14-6-2013$ & 20 & 30 & 204988 & 399621 & $2 \mathrm{~d} 512$ & VIo & 75 & 170 \\
\hline 10034 & Wel11 & $14-6-2013$ & 20 & 30 & 204988 & 399621 & $2 \mathrm{~d} 512$ & VIo & 75 & 170 \\
\hline 10035 & Wel12 & $14-6-2013$ & 65 & 75 & 204988 & 399621 & $2 \mathrm{~d} 512$ & VIo & 75 & 170 \\
\hline 10036 & Wel12 & $14-6-2013$ & 65 & 75 & 204988 & 399621 & $2 \mathrm{~d} 512$ & VIo & 75 & 170 \\
\hline 10037 & Luy11 & $17-6-2013$ & 10 & 20 & 150486 & 365497 & $4 i 432$ & VIo & 65 & 170 \\
\hline 10038 & Luy11 & $17-6-2013$ & 10 & 20 & 150486 & 365497 & $4 i 432$ & VIo & 65 & 170 \\
\hline 10039 & Luy12 & $17-6-2013$ & 35 & 45 & 150486 & 365497 & $4 i 432$ & VIo & 65 & 170 \\
\hline 10040 & Luy12 & $17-6-2013$ & 35 & 45 & 150486 & 365497 & $4 i 432$ & VIo & 65 & 170 \\
\hline 10041 & Ben11 & $16-7-2013$ & 10 & 20 & 131684 & 524276 & k4k4111a & VIo & 45 & 130 \\
\hline 10042 & Ben11 & $16-7-2013$ & 10 & 20 & 131684 & 524276 & k4k4111a & VIo & 45 & 130 \\
\hline 10043 & Ben12 & $16-7-2013$ & 45 & 55 & 131684 & 524276 & k4k4111a & VIo & 45 & 130 \\
\hline 10044 & Ben12 & $16-7-2013$ & 45 & 55 & 131684 & 524276 & k4k4111a & VIo & 45 & 130 \\
\hline 10045 & Rog1 & $16-7-2013$ & 60 & 70 & 183900 & 508200 & $5 \mathrm{k} 4211 \mathrm{a} / \mathrm{F}$ & Vbo & 30 & 130 \\
\hline 10046 & Rog1 & $16-7-2013$ & 60 & 70 & 183900 & 508200 & $5 \mathrm{k} 4211 \mathrm{a} / \mathrm{F}$ & Vbo & 30 & 130 \\
\hline 10047 & Oud11 & $18-7-2013$ & 30 & 40 & 115885 & 537826 & $4 \mathrm{k} 4311 \mathrm{c} / \mathrm{H}$ & IVu & 45 & 120 \\
\hline 10048 & Oud11 & $18-7-2013$ & 30 & 40 & 115885 & 537826 & $4 \mathrm{k} 4311 \mathrm{c} / \mathrm{H}$ & IVu & 45 & 120 \\
\hline 10049 & Oud12 & $18-7-2013$ & 55 & 65 & 115885 & 537826 & $4 \mathrm{k} 4311 \mathrm{c} / \mathrm{H}$ & IVu & 45 & 120 \\
\hline 10050 & Oud12 & $18-7-2013$ & 55 & 65 & 115885 & 537826 & $4 \mathrm{k} 4311 \mathrm{c} / \mathrm{H}$ & IVu & 45 & 120 \\
\hline 10051 & Ber1N & $10-7-2013$ & 60 & 70 & 106130 & 520320 & $5 k 511$ & VIId & 115 & 220 \\
\hline
\end{tabular}




\begin{tabular}{|c|c|c|c|c|c|c|c|c|c|c|}
\hline \multirow[t]{2}{*}{ MIN } & \multirow[t]{2}{*}{$\begin{array}{l}\text { Monster } \\
\text { Naam }\end{array}$} & \multirow[t]{2}{*}{$\begin{array}{l}\text { Monster } \\
\text { Datum }\end{array}$} & \multicolumn{2}{|c|}{$\begin{array}{c}\text { Monster Diepte } \\
(\mathrm{cm}-\mathrm{mv})\end{array}$} & \multicolumn{2}{|c|}{ RD-Coördinaten } & \multirow[t]{2}{*}{ StdPntCd } & \multirow[t]{2}{*}{ Gt } & \multirow[t]{2}{*}{ GHG } & \multirow[t]{2}{*}{ GLG } \\
\hline & & & van & tot & $\mathrm{x}$ & $\mathbf{Y}$ & & & & \\
\hline 10052 & Ber1N & $10-7-2013$ & 60 & 70 & 106130 & 520320 & $5 k 511$ & VIId & 115 & 220 \\
\hline 10053 & Rek1N & $12-7-2013$ & 70 & 80 & 248429 & 459637 & $4 i 512$ & VIo & 60 & 150 \\
\hline 10054 & Rek1N & $12-7-2013$ & 70 & 80 & 248429 & 459637 & $4 i 512$ & VIo & 60 & 150 \\
\hline 10055 & Gor2N & $5-7-2013$ & 45 & 55 & 208039 & 467912 & $\mathrm{R} 5 \times 235 \mathrm{c}$ & VIId & 90 & 200 \\
\hline 10056 & Gor2N & $5-7-2013$ & 45 & 55 & 208039 & 467912 & $\mathrm{R} 5 \times 235 \mathrm{c}$ & VIId & 90 & 200 \\
\hline 10057 & Gie1 & $9-7-2013$ & 50 & 60 & 129600 & 422520 & $\mathrm{R} 5 \times 222 \mathrm{c}$ & VIId & 90 & 190 \\
\hline 10058 & Gie1 & $9-7-2013$ & 50 & 60 & 129600 & 422520 & $\mathrm{R} 5 \times 222 \mathrm{c}$ & VIId & 90 & 190 \\
\hline 10059 & Ens11 & $26-6-2013$ & 5 & 15 & 259885 & 467940 & mK4p225cg14 & Vad & 20 & 300 \\
\hline 10060 & Ens11 & $26-6-2013$ & 5 & 15 & 259885 & 467940 & mK4p225cg14 & Vad & 20 & 300 \\
\hline 10061 & Ens12 & $26-6-2013$ & 40 & 50 & 259885 & 467940 & mK4p225cg14 & Vad & 20 & 300 \\
\hline 10062 & Ens12 & $26-6-2013$ & 40 & 50 & 259885 & 467940 & $\mathrm{mK} 4 \mathrm{p} 225 \mathrm{cg} 14$ & Vad & 20 & 300 \\
\hline 10063 & $\mathrm{HoO} 2$ & $27-6-2013$ & 35 & 45 & 232493 & 549592 & K5p215c & Vad & 20 & 300 \\
\hline 10064 & $\mathrm{Hoo} 2$ & $27-6-2013$ & 35 & 45 & 232493 & 549592 & K5p215c & Vad & 20 & 300 \\
\hline 10065 & $\operatorname{Sch} 1$ & $1-7-2013$ & 30 & 40 & 238852 & 442855 & $4 \mathrm{k} 512$ & VId & 70 & 200 \\
\hline 10066 & Sch1 & $1-7-2013$ & 30 & 40 & 238852 & 442855 & $4 \mathrm{k} 512$ & VId & 70 & 200 \\
\hline 10067 & Blo1N & $4-9-2013$ & 10 & 20 & 192200 & 526690 & $5 \mathrm{k} 4111 \mathrm{a}$ & VIId & 100 & 230 \\
\hline 10068 & Blo1N & $4-9-2013$ & 10 & 20 & 192200 & 526690 & $5 \mathrm{k} 4111 \mathrm{a}$ & VIId & 100 & 230 \\
\hline 10069 & Wy 1 & $6-11-2013$ & 90 & 100 & 177580 & 425845 & $4 s 511$ & VIIId & 150 & 250 \\
\hline 10070 & Wy1 & $6-11-2013$ & 90 & 100 & 177580 & 425845 & $4 s 511$ & VIIId & 150 & 250 \\
\hline 10071 & Kou1 & $6-11-2013$ & 70 & 80 & 173972 & 470815 & $2 i 511$ & VIIId & 500 & 600 \\
\hline 10072 & Kou1 & $6-11-2013$ & 70 & 80 & 173972 & 470815 & $2 \mathrm{i} 511$ & VIIId & 500 & 600 \\
\hline 10073 & Gro11 & $3-4-2014$ & 15 & 25 & 194130 & 423304 & $5 \times 81$ & VIIId & - & - \\
\hline 10074 & Gro11 & $3-4-2014$ & 15 & 25 & 194130 & 423304 & $5 \times 81$ & VIIId & - & - \\
\hline 10075 & Gro12 & $3-4-2014$ & 50 & 60 & 194130 & 423304 & $5 \times 81$ & VIIId & - & - \\
\hline 10076 & Gro12 & $3-4-2014$ & 50 & 60 & 194130 & 423304 & $5 \times 81$ & VIIId & - & - \\
\hline 10077 & Rhe2 & $3-4-2014$ & 45 & 55 & 198965 & 448105 & $5 \times 81$ & VIIId & - & - \\
\hline 10078 & Rhe2 & $3-4-2014$ & 45 & 55 & 198965 & 448105 & $5 \times 81$ & VIIId & - & - \\
\hline 10079 & Wou11 & $16-4-2014$ & 10 & 20 & 86475 & 394400 & $4 s 424$ & VIIo & 85 & 180 \\
\hline 10080 & Wou11 & $16-4-2014$ & 10 & 20 & 86475 & 394400 & $4 s 424$ & VIIo & 85 & 180 \\
\hline 10081 & Wou12 & $16-4-2014$ & 55 & 65 & 86475 & 394400 & $4 s 424$ & VIIo & 85 & 180 \\
\hline 10082 & Wou12 & $16-4-2014$ & 55 & 65 & 86475 & 394400 & $4 s 424$ & VIIo & 85 & 180 \\
\hline 10083 & Ril11 & $16-4-2014$ & 10 & 20 & 73174 & 382847 & $5 \mathrm{k} 4212 \mathrm{a}$ & VIIo & 85 & 130 \\
\hline 10084 & Ril11 & $16-4-2014$ & 10 & 20 & 73174 & 382847 & $5 \mathrm{k} 4212 \mathrm{a}$ & VIIo & 85 & 130 \\
\hline 10085 & Ril12 & $16-4-2014$ & 40 & 50 & 73174 & 382847 & $5 \mathrm{k} 4212 \mathrm{a}$ & VIIo & 85 & 130 \\
\hline 10086 & Ril12 & $16-4-2014$ & 40 & 50 & 73174 & 382847 & $5 \mathrm{k} 4212 \mathrm{a}$ & VIIo & 85 & 130 \\
\hline 10087 & Raa11 & $14-5-2014$ & 15 & 25 & 218895 & 493210 & $2 q 424$ & Vbo & 35 & 160 \\
\hline 10088 & Raa11 & $14-5-2014$ & 15 & 25 & 218895 & 493210 & $2 q 424$ & Vbo & 35 & 160 \\
\hline 10089 & Raa12 & $14-5-2014$ & 35 & 45 & 218895 & 493210 & $2 q 424$ & Vbo & 35 & 160 \\
\hline 10090 & Raa12 & $14-5-2014$ & 35 & 45 & 218895 & 493210 & $2 q 424$ & Vbo & 35 & 160 \\
\hline 10091 & Lau11 & $14-5-2014$ & 10 & 20 & 215400 & 594350 & $5 \mathrm{k} 4212 \mathrm{a}$ & VIIo & 85 & 130 \\
\hline 10092 & Lau11 & $14-5-2014$ & 10 & 20 & 215400 & 594350 & $5 \mathrm{k} 4212 \mathrm{a}$ & VIIo & 85 & 130 \\
\hline 10093 & Lau12 & $14-5-2014$ & 35 & 45 & 215400 & 594350 & $5 \mathrm{k} 4212 \mathrm{a}$ & VIIo & 85 & 130 \\
\hline 10094 & Lau12 & $14-5-2014$ & 35 & 45 & 215400 & 594350 & $5 \mathrm{k} 4212 \mathrm{a}$ & VIIo & 85 & 130 \\
\hline 10095 & Kam11 & $28-5-2014$ & 5 & 15 & 122550 & 458880 & $\mathrm{R} 4 \mathrm{~m} 311 \mathrm{c}$ & IIIb & 30 & 90 \\
\hline 10096 & Kam11 & $28-5-2014$ & 5 & 15 & 122550 & 458880 & $\mathrm{R} 4 \mathrm{~m} 311 \mathrm{c}$ & IIIb & 30 & 90 \\
\hline 10097 & Kam12 & $28-5-2014$ & 35 & 45 & 122550 & 458880 & $\mathrm{R} 4 \mathrm{~m} 311 \mathrm{c}$ & IIIb & 30 & 90 \\
\hline 10098 & Kam12 & $28-5-2014$ & 35 & 45 & 122550 & 458880 & $\mathrm{R} 4 \mathrm{~m} 311 \mathrm{c}$ & IIIb & 30 & 90 \\
\hline 10099 & Nie1 & $28-5-2014$ & 5 & 15 & 110108 & 461622 & v4c3214 & IIb & 25 & 75 \\
\hline 10100 & Nie1 & $28-5-2014$ & 5 & 15 & 110108 & 461622 & v4c3214 & IIb & 25 & 75 \\
\hline 10101 & Lar1kop & $9-5-2016$ & 5 & 15 & 226120 & 467695 & $2 r 422$ & VIo & 70 & 160 \\
\hline 10102 & Lar1kop & $9-5-2016$ & 5 & 15 & 226120 & 467695 & $2 \mathrm{r} 422$ & VIo & 70 & 160 \\
\hline 10103 & Lar1kop & $9-5-2016$ & 35 & 45 & 226120 & 467695 & $2 r 422$ & VIo & 70 & 160 \\
\hline 10104 & Lar1kop & $9-5-2016$ & 35 & 45 & 226120 & 467695 & $2 r 422$ & VIo & 70 & 160 \\
\hline 10105 & Lar1kop & $9-5-2016$ & 60 & 70 & 226120 & 467695 & $2 r 422$ & VIo & 70 & 160 \\
\hline 10106 & Lar1kop & $9-5-2016$ & 60 & 70 & 226120 & 467695 & $2 r 422$ & VIo & 70 & 160 \\
\hline 10107 & Lar2mid & $9-5-2016$ & 35 & 45 & 226120 & 467695 & $2 q 423$ & VIo & 60 & 150 \\
\hline
\end{tabular}




\begin{tabular}{|c|c|c|c|c|c|c|c|c|c|c|}
\hline \multirow[t]{2}{*}{ MIN } & \multirow[t]{2}{*}{$\begin{array}{l}\text { Monster } \\
\text { Naam }\end{array}$} & \multirow[t]{2}{*}{$\begin{array}{l}\text { Monster } \\
\text { Datum }\end{array}$} & \multicolumn{2}{|c|}{$\begin{array}{c}\text { Monster Diepte } \\
(\mathrm{cm}-\mathrm{mv})\end{array}$} & \multicolumn{2}{|c|}{ RD-Coördinaten } & \multirow[t]{2}{*}{ StdPntCd } & \multirow[t]{2}{*}{ Gt } & \multirow[t]{2}{*}{ GHG } & \multirow[t]{2}{*}{ GLG } \\
\hline & & & van & tot & $\mathrm{x}$ & $\mathbf{Y}$ & & & & \\
\hline 10108 & Lar2mid & $9-5-2016$ & 60 & 70 & 226120 & 467695 & $2 q 423$ & VIo & 60 & 150 \\
\hline 10109 & Lar3 & $3-6-2016$ & 33 & 43 & 226233 & 467924 & $2 r 432$ & VIo & 60 & 130 \\
\hline 10110 & Lar3 & $3-6-2016$ & 33 & 43 & 226233 & 467924 & $2 r 432$ & VIo & 60 & 130 \\
\hline 10111 & Ker1A/B & $4-5-2016$ & 16 & 26 & 155197 & 434993 & R5p235c & VIo & 75 & 160 \\
\hline 10112 & Ker1A/B & $4-5-2016$ & 16 & 26 & 155197 & 434993 & R5p235c & VIo & 75 & 160 \\
\hline 10113 & Ker1A0/B0 & $4-5-2016$ & 50 & 60 & 155197 & 434993 & R5p235c & VIo & 75 & 160 \\
\hline 10114 & Ker1A0/B0 & $4-5-2016$ & 50 & 60 & 155197 & 434993 & R5p235c & VIo & 75 & 160 \\
\hline 10115 & Wes2 & $4-5-2016$ & 12 & 22 & 89996 & 422630 & M5p235a & VIo & 60 & 160 \\
\hline 10116 & Wes2 & $4-5-2016$ & 12 & 22 & 89996 & 422630 & M5p235a & VIo & 60 & 160 \\
\hline 10117 & Spr2x_15 & $25-5-2016$ & 15 & 25 & 126690 & 413680 & M5p235a & IVu & 60 & 110 \\
\hline 10118 & Spr2x_15 & $25-5-2016$ & 15 & 25 & 126690 & 413680 & M5p235a & IVu & 60 & 110 \\
\hline 10119 & Spr2x_43 & $25-5-2016$ & 43 & 53 & 126690 & 413680 & M5p235a & IVu & 60 & 110 \\
\hline 10121 & NV1 & $13-6-2016$ & 15 & 25 & 105092 & 476734 & $5 p 232 b$ & VIo & 70 & 130 \\
\hline 10122 & NV1 & $13-6-2016$ & 15 & 25 & 105092 & 476734 & $5 p 232 b$ & VIo & 70 & 130 \\
\hline 10123 & $91 a$ & $24-2-2004$ & 7 & 17 & 144669 & 429099 & R5p334c & IIIa & 15 & 120 \\
\hline 10124 & $92 a$ & $24-2-2004$ & 37 & 47 & 144669 & 429099 & R5p334c & IIIa & 15 & 120 \\
\hline 10125 & $93 a$ & $24-2-2004$ & 60 & 75 & 144669 & 429099 & R5p334c & IIIa & 15 & 120 \\
\hline 10126 & $93 b$ & $24-2-2004$ & 60 & 75 & 144669 & 429099 & R5p334c & IIIa & 15 & 120 \\
\hline 10127 & $95 a$ & $24-2-2004$ & 140 & 155 & 144669 & 429099 & R5p334c & IIIa & 15 & 120 \\
\hline 10128 & $95 b$ & $24-2-2004$ & 140 & 155 & 144669 & 429099 & R5p334c & IIIa & 15 & 120 \\
\hline 10129 & $101 b$ & $12-3-2004$ & 7 & 17 & 144697 & 429164 & R5p334c & Vbo & 30 & 130 \\
\hline 10130 & $102 a$ & $12-3-2004$ & 35 & 45 & 144697 & 429164 & R5p334c & Vbo & 30 & 130 \\
\hline 10131 & $102 b$ & $12-3-2004$ & 35 & 45 & 144697 & 429164 & R5p334c & Vbo & 30 & 130 \\
\hline 10132 & $103 b$ & $12-3-2004$ & 65 & 75 & 144697 & 429164 & R5p334c & Vbo & 30 & 130 \\
\hline 10133 & $4-40-i$ & $3-4-2017$ & 40 & 48 & 129843.52 & 399406.89 & $5 k 432$ & VIId & 100 & 200 \\
\hline 10134 & $4-135-i$ & 3-4-2017 & 135 & 145 & 129843.52 & 399406.89 & $5 k 432$ & VIId & 100 & 200 \\
\hline 10135 & $4-180-i$ & $27-3-2017$ & 180 & 190 & 129843.52 & 399406.89 & $5 k 432$ & VIId & 100 & 200 \\
\hline 10136 & $5-45-i$ & $3-4-2017$ & 45 & 55 & 129695.35 & 399241.2 & $5 \mathrm{k} 422 \mathrm{~F}$ & VIId & 110 & 200 \\
\hline 10137 & $5-230-i$ & $27-3-2017$ & 230 & 240 & 129695.35 & 399241.2 & $5 \mathrm{k} 422 \mathrm{~F}$ & VIId & 110 & 200 \\
\hline 10138 & $5-270-i$ & $3-4-2017$ & 270 & 275 & 129695.35 & 399241.2 & $5 \mathrm{k} 422 \mathrm{~F}$ & VIId & 110 & 200 \\
\hline 10139 & 6-80-i & 4-4-2017 & 80 & 85 & 129777.6 & 399192.52 & $4 \mathrm{~s} 422 \mathrm{H}$ & VIIId & 150 & 250 \\
\hline 10140 & $6-130-i$ & $27-3-2017$ & 130 & 140 & 129777.6 & 399192.52 & $4 s 422 \mathrm{H}$ & VIIId & 150 & 250 \\
\hline 10141 & $6-155-i$ & 27-3-2017 & 155 & 165 & 129777.6 & 399192.52 & $4 s 422 \mathrm{H}$ & VIIId & 150 & 250 \\
\hline 10142 & $11-40-i$ & 4-4-2017 & 40 & 45 & 129998.47 & 398879.79 & $\mathrm{c} 4 \mathrm{i} 42 * 2 \mathrm{t} 8 \mathrm{~F}$ & VIo & 60 & 160 \\
\hline 10143 & $11-80-i$ & 4-4-2017 & 80 & 85 & 129998.47 & 398879.79 & $\mathrm{c} 4 \mathrm{i} 42 * 2 \mathrm{t} 8 \mathrm{~F}$ & VIo & 60 & 160 \\
\hline 10144 & $12-80-i$ & $28-3-2017$ & 80 & 90 & 130137.25 & 398327.73 & 2 r422t8 & VIo & 50 & 150 \\
\hline 10145 & $12-190-i$ & $28-3-2017$ & 190 & 200 & 130137.25 & 398327.73 & $2 \mathrm{r} 422 \mathrm{t} 8$ & VIo & 50 & 150 \\
\hline 10146 & voe1.1 & $20-9-2017$ & 6 & 16 & 194950.58 & 320502.35 & $3 i 82 g 16$ & VIIId & 190 & 500 \\
\hline 10147 & voe 1.2 & $20-9-2017$ & 6 & 16 & 194950.58 & 320502.35 & $3 i 82 \mathrm{~g} 16$ & VIIId & 190 & 500 \\
\hline 10148 & voe2.1 & $20-9-2017$ & 58 & 68 & 194950.58 & 320502.35 & $3 i 82 g 16$ & VIIId & 190 & 500 \\
\hline 10149 & voe 2.2 & 20-9-2017 & 58 & 68 & 194950.58 & 320502.35 & $3 \mathrm{i} 82 \mathrm{~g} 16$ & VIIId & 190 & 500 \\
\hline 10150 & wijb2.1 & $26-9-2017$ & 40 & 50 & 159709.1 & 405562.88 & $5 \mathrm{~h} 423 \mathrm{t} 7$ & IIIa & 15 & 100 \\
\hline 10151 & wijb2.2 & $26-9-2017$ & 40 & 50 & 159709.1 & 405562.88 & 5h423t7 & IIIa & 15 & 100 \\
\hline 10152 & Aar1.1 & $28-9-2017$ & 7 & 17 & 153137.18 & 393918.79 & $4 \mathrm{k} 424 \mathrm{~g} 4 \mathrm{t} 9$ & IIIa & 10 & 90 \\
\hline 10153 & Aar1.2 & 28-9-2017 & 7 & 17 & 153137.18 & 393918.79 & $4 \mathrm{k} 424 \mathrm{~g} 4 \mathrm{tg}$ & IIIa & 10 & 90 \\
\hline 10154 & 016.1 & $17-10-2017$ & 25 & 35 & 268312.02 & 530506.54 & $1 v p 5 G$ & VIo & 70 & 160 \\
\hline 10155 & 016.2 & $17-10-2017$ & 25 & 35 & 268312.02 & 530506.54 & 1vp5G & VIo & 70 & 160 \\
\hline
\end{tabular}




\section{Bijlage 7 Textuurgegevens}

De textuurgegevens van deze tabel zijn gebaseerd op gemeten gewichtsfracties van de minerale delen die kleiner zijn dan $2000 \mu \mathrm{m}$. Fracties ten opzichte van minerale delen kunnen (vooral bij organisch stofrijke bodemmonsters) een vertekend beeld geven als men in de bulkhoeveelheden is geïnteresseerd. In dat geval moeten ook het organisch stofgehalte, kalkgehalte, ijzergehalte en de fractie $>2000 \mu \mathrm{m}$ worden beschouwd. Als monsters in deze tabel geen waarden bevatten, kan het zijn dat er wel geschatte fracties zijn. Die zijn dan terug te vinden in de bijlage "Belangrijke Veldgegevens". Ook de in het veld geschatte textuurfracties zijn gebaseerd op de totale minerale fractie. Organische stoffracties zijn gebaseerd op het bulkgewicht.

\begin{tabular}{|c|c|c|c|c|c|c|c|c|c|c|c|c|}
\hline \multirow[t]{2}{*}{ MIN } & 0 & 2 & 16 & 2 & 50 & 63 & 50 & 105 & 150 & 150 & 210 & 420 \\
\hline & 2 & 16 & 50 & 50 & 63 & 105 & 105 & 150 & 2000 & 210 & 420 & 2000 \\
\hline 50 & P.M. & P.M. & P.M. & P.M. & P.M. & P.M. & P.M. & P.M. & P.M. & P.M. & P.M. & P.M. \\
\hline 60 & P.M. & P.M. & P.M. & P.M. & P.M. & P.M. & P.M. & P.M. & P.M. & P.M. & P.M. & P.M. \\
\hline 67 & P.M. & P.M. & P.M. & P.M. & P.M. & P.M. & P.M. & P.M. & P.M. & P.M. & P.M. & P.M. \\
\hline 1611 & P.M. & P.M. & P.M. & P.M. & P.M. & P.M. & P.M. & P.M. & P.M. & P.M. & P.M. & P.M. \\
\hline 1612 & P.M. & P.M. & P.M. & P.M. & P.M. & P.M. & P.M. & P.M. & P.M. & P.M. & P.M. & P.M. \\
\hline 1613 & P.M. & P.M. & P.M. & P.M. & P.M. & P.M. & P.M. & P.M. & P.M. & P.M. & P.M. & P.M. \\
\hline 1614 & P.M. & P.M. & P.M. & P.M. & P.M. & P.M. & P.M. & P.M. & P.M. & P.M. & P.M. & P.M. \\
\hline 1621 & P.M. & P.M. & P.M. & P.M. & P.M. & P.M. & P.M. & P.M. & P.M. & P.M. & P.M. & P.M. \\
\hline 1622 & P.M. & P.M. & P.M. & P.M. & P.M. & P.M. & P.M. & P.M. & P.M. & P.M. & P.M. & P.M. \\
\hline 1624 & P.M. & P.M. & P.M. & P.M. & P.M. & P.M. & P.M. & P.M. & P.M. & P.M. & P.M. & P.M. \\
\hline 1631 & P.M. & P.M. & P.M. & P.M. & P.M. & P.M. & P.M. & P.M. & P.M. & P.M. & P.M. & P.M. \\
\hline 1632 & P.M. & P.M. & P.M. & P.M. & P.M. & P.M. & P.M. & P.M. & P.M. & P.M. & P.M. & P.M. \\
\hline 1633 & P.M. & P.M. & P.M. & P.M. & P.M. & P.M. & P.M. & P.M. & P.M. & P.M. & P.M. & P.M. \\
\hline 1643 & P.M. & P.M. & P.M. & P.M. & P.M. & P.M. & P.M. & P.M. & P.M. & P.M. & P.M. & P.M. \\
\hline 1644 & P.M. & P.M. & P.M. & P.M. & P.M. & P.M. & P.M. & P.M. & P.M. & P.M. & P.M. & P.M. \\
\hline 1645 & P.M. & P.M. & P.M. & P.M. & P.M. & P.M. & P.M. & P.M. & P.M. & P.M. & P.M. & P.M. \\
\hline 1646 & P.M. & P.M. & P.M. & P.M. & P.M. & P.M. & P.M. & P.M. & P.M. & P.M. & P.M. & P.M. \\
\hline 1650 & P.M. & P.M. & P.M. & P.M. & P.M. & P.M. & P.M. & P.M. & P.M. & P.M. & P.M. & P.M. \\
\hline 1651 & P.M. & P.M. & P.M. & P.M. & P.M. & P.M. & P.M. & P.M. & P.M. & P.M. & P.M. & P.M. \\
\hline 1653 & P.M. & P.M. & P.M. & P.M. & P.M. & P.M. & P.M. & P.M. & P.M. & P.M. & P.M. & P.M. \\
\hline 1654 & P.M. & P.M. & P.M. & P.M. & P.M. & P.M. & P.M. & P.M. & P.M. & P.M. & P.M. & P.M. \\
\hline 1655 & P.M. & P.M. & P.M. & P.M. & P.M. & P.M. & P.M. & P.M. & P.M. & P.M. & P.M. & P.M. \\
\hline 1656 & P.M. & P.M. & P.M. & P.M. & P.M. & P.M. & P.M. & P.M. & P.M. & P.M. & P.M. & P.M. \\
\hline 1663 & P.M. & P.M. & P.M. & P.M. & P.M. & P.M. & P.M. & P.M. & P.M. & P.M. & P.M. & P.M. \\
\hline 1664 & P.M. & P.M. & P.M. & P.M. & P.M. & P.M. & P.M. & P.M. & P.M. & P.M. & P.M. & P.M. \\
\hline 1665 & P.M. & P.M. & P.M. & P.M. & P.M. & P.M. & P.M. & P.M. & P.M. & P.M. & P.M. & P.M. \\
\hline 1666 & P.M. & P.M. & P.M. & P.M. & P.M. & P.M. & P.M. & P.M. & P.M. & P.M. & P.M. & P.M. \\
\hline 1675 & P.M. & P.M. & P.M. & P.M. & P.M. & P.M. & P.M. & P.M. & P.M. & P.M. & P.M. & P.M. \\
\hline 1676 & P.M. & P.M. & P.M. & P.M. & P.M. & P.M. & P.M. & P.M. & P.M. & P.M. & P.M. & P.M. \\
\hline 1677 & P.M. & P.M. & P.M. & P.M. & P.M. & P.M. & P.M. & P.M. & P.M. & P.M. & P.M. & P.M. \\
\hline 1678 & P.M. & P.M. & P.M. & P.M. & P.M. & P.M. & P.M. & P.M. & P.M. & P.M. & P.M. & P.M. \\
\hline 1679 & P.M. & P.M. & P.M. & P.M. & P.M. & P.M. & P.M. & P.M. & P.M. & P.M. & P.M. & P.M. \\
\hline 1680 & P.M. & P.M. & P.M. & P.M. & P.M. & P.M. & P.M. & P.M. & P.M. & P.M. & P.M. & P.M. \\
\hline 1681 & P.M. & P.M. & P.M. & P.M. & P.M. & P.M. & P.M. & P.M. & P.M. & P.M. & P.M. & P.M. \\
\hline 1682 & 0.5 & 0.7 & 5.1 & - & 4.7 & 24.3 & - & 34.7 & - & 18.3 & 9 & 2.7 \\
\hline 1684 & 80.1 & 8.3 & 1.1 & - & 0.3 & 0.7 & - & 1.8 & 7.7 & - & - & - \\
\hline 1685 & 80.1 & 8.3 & 1.1 & - & 0.3 & 0.7 & - & 1.8 & 7.7 & - & - & - \\
\hline 1686 & 90.3 & 4.1 & - & - & - & - & - & - & - & - & - & - \\
\hline 1687 & - & - & - & - & - & - & - & - & - & - & - & - \\
\hline
\end{tabular}




\begin{tabular}{|c|c|c|c|c|c|c|c|c|c|c|c|c|}
\hline \multirow[t]{2}{*}{ MIN } & 0 & 2 & 16 & 2 & 50 & 63 & 50 & 105 & 150 & 150 & 210 & 420 \\
\hline & 2 & 16 & 50 & 50 & 63 & 105 & 105 & 150 & 2000 & 210 & 420 & 2000 \\
\hline 1690 & - & - & - & - & - & - & - & - & - & - & - & - \\
\hline 1692 & 52.4 & 12.6 & 3.4 & - & 0.5 & 1.7 & - & 4.5 & 24.9 & - & - & - \\
\hline 1693 & 52.4 & 12.6 & 3.4 & - & 0.5 & 1.7 & - & 4.5 & 24.9 & - & - & - \\
\hline 1695 & - & - & - & - & - & - & - & - & - & - & - & - \\
\hline 1830 & - & - & - & - & - & - & - & - & - & - & - & - \\
\hline 10001 & 14.5 & 9.1 & 11.7 & 0 & 24.6 & 38.3 & - & 0.8 & - & 0.3 & 0.3 & 0.4 \\
\hline 10002 & 17.3 & 9.9 & 13.9 & 0 & 17.1 & 36.9 & - & 2.1 & - & 1.2 & 0.9 & 0.9 \\
\hline 10003 & 25.2 & 19.2 & 17.5 & 0 & 2.6 & 6.8 & - & 6.5 & - & 10 & 10.6 & 1.6 \\
\hline 10004 & 26.1 & 18.1 & 13.4 & 0 & 5.7 & 8.6 & - & 5.4 & - & 11 & 10.5 & 1.2 \\
\hline 10005 & 19.6 & 16.5 & 16.2 & 0 & 2.4 & 8 & - & 5 & - & 11.5 & 20.5 & 0.4 \\
\hline 10006 & 18.5 & 14 & 13 & 0 & 5.4 & 9.2 & - & 3.5 & - & 13 & 23.1 & 0.5 \\
\hline 10007 & 25.2 & 20.4 & 23 & 0 & 7 & 19.6 & - & 2.8 & - & 0.9 & 1.1 & 0.1 \\
\hline 10008 & 26.5 & 18.1 & 22.6 & 0 & 11 & 18.1 & - & 1.1 & - & 1.1 & 1 & 0.5 \\
\hline 10009 & 16.6 & 10.3 & 7.6 & 0 & 3.4 & 11.4 & - & 14.1 & - & 17.6 & 11.9 & 7.1 \\
\hline 10010 & 16.4 & 10.6 & 9.9 & 0 & 2.8 & 11.5 & - & 10.6 & - & 17.4 & 13.6 & 7.2 \\
\hline 10011 & 18.3 & 15.6 & 19.2 & 0 & 2.1 & 12 & - & 16.6 & - & 11.6 & 4.4 & 0.2 \\
\hline 10012 & 17.4 & 13.4 & 13.6 & 0 & 7.2 & 15 & - & 14.7 & - & 13.4 & 5 & 0.3 \\
\hline 10013 & 39.3 & 20.1 & 22.6 & 0 & 5.1 & 8.7 & - & 1.4 & - & 0.7 & 0.9 & 1.1 \\
\hline 10014 & 44 & 20.8 & 18.9 & 0 & 6.8 & 7.1 & - & 0.6 & - & 0.6 & 0.7 & 0.7 \\
\hline 10015 & 30.8 & 30.2 & 23.5 & 0 & 5.7 & 4.9 & - & 2 & - & 1.1 & 1.2 & 0.7 \\
\hline 10016 & 26.2 & 29 & 8.9 & 0 & 16.2 & 12.7 & - & 2.1 & - & 1.9 & 2.4 & 0.7 \\
\hline 10017 & 25.5 & 13.4 & 21.6 & 0 & 9.7 & 20.3 & - & 5.4 & - & 1.1 & 2.5 & 0.4 \\
\hline 10018 & 19.5 & 9.4 & 19.3 & 0 & 8.5 & 39.6 & - & 2.7 & - & 0.4 & 0.5 & 0.1 \\
\hline 10019 & 26.2 & 14.6 & 30.1 & 0 & 10.4 & 13.4 & - & 1.8 & - & 1.1 & 1.6 & 0.9 \\
\hline 10020 & 31.2 & 16.9 & 30.5 & 0 & 9.7 & 9.2 & - & 0.7 & - & 0.4 & 0.6 & 0.8 \\
\hline 10021 & 16.4 & 6.9 & 13.2 & 0 & 2.2 & 40.1 & - & 19.1 & - & 0.8 & 0.7 & 0.7 \\
\hline 10022 & 16.8 & 9.7 & 10.2 & 0 & 4.6 & 54 & - & 3.8 & - & 0.3 & 0.3 & 0.4 \\
\hline 10023 & 27 & 0 & 36.1 & 0 & 1.9 & 9.7 & - & 6.9 & - & 6.9 & 8.1 & 3.4 \\
\hline 10024 & 25.6 & 21.2 & 14.3 & 0 & 4.1 & 9.6 & - & 6.1 & - & 7.3 & 8.6 & 3.3 \\
\hline 10025 & 30.2 & 16.5 & 15.4 & 0 & 6.3 & 5 & - & 7.5 & - & 4.6 & 8.1 & 6.4 \\
\hline 10026 & 23.5 & 14.2 & 9.4 & 0 & 12.4 & 21.7 & - & 5.7 & - & 4.8 & 5.1 & 3.2 \\
\hline 10027 & 30.4 & 26.4 & 12 & 0 & 3.8 & 6.8 & - & 5.1 & - & 8.3 & 6.3 & 0.8 \\
\hline 10028 & 30.6 & 27.4 & 13 & 0 & 3.4 & 6.4 & - & 4.9 & - & 8 & 5.8 & 0.5 \\
\hline 10029 & 5.7 & 1.8 & 4.4 & 0 & 0.8 & 4.6 & - & 5.8 & - & 14.9 & 37.8 & 24.2 \\
\hline 10030 & 5.4 & 2.6 & 3.7 & 0 & 1.2 & 4.1 & - & 5.3 & - & 14.2 & 39.5 & 24 \\
\hline 10031 & 5.4 & 4.7 & 3.9 & 0 & 1.5 & 3.9 & - & 4.8 & - & 16.3 & 42.8 & 16.6 \\
\hline 10032 & 5.1 & 5.3 & 2.5 & 0 & 1.8 & 3.6 & - & 4.4 & - & 16.2 & 45.6 & 15.6 \\
\hline 10033 & 1 & 1.1 & 0.2 & 0 & 0.1 & 1.2 & - & 4.6 & - & 21.8 & 55.1 & 14.8 \\
\hline 10034 & 1.9 & 0.4 & 0 & 0 & 0.2 & 1.3 & - & 4.8 & - & 22.2 & 55.7 & 13.5 \\
\hline 10035 & 0.6 & 0.5 & -0.2 & 0 & 0.1 & 1.2 & - & 6.4 & - & 27.2 & 56.4 & 7.8 \\
\hline 10036 & 0.9 & 0.2 & -0.4 & 0 & 0 & 0.9 & - & 4.8 & - & 24.1 & 59.1 & 10.4 \\
\hline 10037 & 4.6 & 1.6 & 2.9 & 0 & 2.3 & 11.4 & - & 15.1 & - & 19.4 & 33.7 & 9 \\
\hline 10038 & 3.9 & 2.9 & 2.7 & 0 & 2.1 & 12 & - & 15.3 & - & 19.8 & 33.1 & 8.2 \\
\hline 10039 & 1.4 & 1.2 & 1.1 & 0 & 0.4 & 1.9 & - & 2.5 & - & 8.6 & 73 & 9.8 \\
\hline 10040 & 0.8 & 2.3 & 0.6 & 0 & 0.7 & 3 & - & 3.2 & - & 8.7 & 69.4 & 11.2 \\
\hline 10041 & 10.5 & 6.9 & 6.3 & 0 & 7.5 & 65.3 & - & 2.5 & - & 0.2 & 0.4 & 0.3 \\
\hline 10042 & 9.9 & 6.4 & 4.1 & 0 & 6.5 & 69.6 & - & 2.8 & - & 0.2 & 0.3 & 0.2 \\
\hline 10043 & 1.3 & 2.3 & 0 & 0 & 1.6 & 88.3 & - & 5.9 & - & 0.2 & 0.1 & 0.2 \\
\hline 10044 & 1.5 & 2.3 & 0.9 & 0 & 3 & 83.1 & - & 8.7 & - & 0.3 & 0.1 & 0.2 \\
\hline 10045 & 0.4 & 1.3 & -0.7 & 0 & 0.1 & 0.6 & - & 1.5 & - & 17.7 & 73.6 & 5.5 \\
\hline 10046 & 0.3 & 1.5 & -1 & 0 & 0.1 & 0.5 & - & 1.6 & - & 17.8 & 75.9 & 3.4 \\
\hline 10047 & 5.4 & 2.4 & 4.3 & 0 & 2.1 & 12.4 & - & 21.9 & - & 27.9 & 23 & 0.6 \\
\hline 10048 & 5.6 & 2.3 & 5 & 0 & 1.7 & 11.9 & - & 21.6 & - & 26.9 & 24.4 & 0.7 \\
\hline 10049 & 2.9 & 0.6 & 2 & 0 & 0.8 & 8 & - & 40.8 & - & 42.7 & 2.1 & 0.1 \\
\hline 10050 & 3.3 & 0.5 & 2.9 & 0 & 0.8 & 8.6 & - & 39.6 & - & 40.1 & 4 & 0.2 \\
\hline 10051 & 0.6 & 1.3 & -0.9 & 0 & 0 & 0.1 & - & 0.9 & - & 37 & 55.5 & 5.5 \\
\hline 10052 & 0.2 & 1.2 & -1 & 0 & 0 & 0.1 & - & 0.9 & - & 36 & 56.2 & 6.4 \\
\hline
\end{tabular}




\begin{tabular}{|c|c|c|c|c|c|c|c|c|c|c|c|c|}
\hline \multirow[t]{2}{*}{ MIN } & 0 & 2 & 16 & 2 & 50 & 63 & 50 & 105 & 150 & 150 & 210 & 420 \\
\hline & 2 & 16 & 50 & 50 & 63 & 105 & 105 & 150 & 2000 & 210 & 420 & 2000 \\
\hline 10053 & 0.7 & 0.8 & -0.4 & 0 & 0 & 0.9 & - & 3.8 & - & 12.8 & 37.5 & 43.9 \\
\hline 10054 & 0.3 & 1.7 & -0.9 & 0 & 0.1 & 1 & - & 4.4 & - & 15.6 & 43.4 & 34.4 \\
\hline 10055 & 4.3 & 1.7 & 2.1 & 0 & 0.8 & 8.5 & - & 13.9 & - & 33.4 & 34.4 & 0.9 \\
\hline 10056 & 2.9 & 1.3 & 2 & 0 & 0.4 & 6.2 & - & 11.2 & - & 29 & 45.4 & 1.7 \\
\hline 10057 & 2.5 & 1.3 & 1.8 & 0 & 0.4 & 4.5 & - & 16.3 & - & 46.8 & 25.6 & 0.8 \\
\hline 10058 & 1.9 & 0.7 & 0.5 & 0 & 0.2 & 4.7 & - & 17.3 & - & 50.3 & 23.8 & 0.5 \\
\hline 10059 & 7.4 & 5.1 & 6.1 & 0 & 2.9 & 20.2 & - & 12.3 & - & 17.9 & 19.2 & 8.9 \\
\hline 10060 & 7.3 & 4.6 & 6.1 & 0 & 3.2 & 20.7 & - & 12.2 & - & 17.8 & 19.2 & 8.9 \\
\hline 10061 & 20.9 & 6 & 5.6 & 0 & 5.8 & 26.8 & - & 6.4 & - & 8.6 & 11.9 & 7.9 \\
\hline 10062 & 19 & 6.1 & 3.6 & 0 & 9.3 & 26.6 & - & 6.6 & - & 8.6 & 12 & 8.1 \\
\hline 10063 & 16 & 6.9 & 4.6 & 0 & 2.7 & 14 & - & 10.9 & - & 15.8 & 19.6 & 9.6 \\
\hline 10064 & 15.2 & 6.6 & 5.2 & 0 & 2.4 & 13.1 & - & 11.7 & - & 16.7 & 20.1 & 8.9 \\
\hline 10065 & 2.5 & 1.4 & 1.9 & 0 & 0.9 & 5.4 & - & 5.5 & - & 12.4 & 22.4 & 47.5 \\
\hline 10066 & 1.9 & 1.7 & 2.6 & 0 & 1.3 & 7 & - & 7.1 & - & 16 & 28.5 & 33.8 \\
\hline 10067 & 2.6 & 1.8 & 6.4 & 0 & 13.6 & 72.3 & - & 1.4 & - & 0.9 & 0.6 & 0.5 \\
\hline 10068 & 2.2 & 2 & 5.7 & 0 & 10 & 77.3 & - & 1.2 & - & 0.8 & 0.5 & 0.3 \\
\hline 10069 & 1.3 & 0.3 & 1.2 & 0 & 0.3 & 2.5 & - & 7.4 & - & 27.9 & 52.5 & 6.6 \\
\hline 10070 & 1 & -0.3 & 1 & 0 & 0.1 & 2 & - & 8.1 & - & 31.2 & 50.4 & 6.5 \\
\hline 10071 & 1.3 & 0.5 & 0.7 & 0 & 0.2 & 0.7 & - & 1 & - & 5.2 & 26.5 & 63.8 \\
\hline 10072 & 1 & 0.7 & 0.8 & 0 & 0.2 & 0.6 & - & 0.8 & - & 4.6 & 25.6 & 65.7 \\
\hline 10073 & 9.8 & 7.5 & 36 & 0 & 15 & 6.1 & - & 4.1 & - & 8.3 & 9 & 4.2 \\
\hline 10074 & 9.9 & 7.3 & 38.1 & 0 & 12.8 & 6.5 & - & 4 & - & 8 & 9.1 & 4.3 \\
\hline 10075 & 7.7 & 9.1 & 32.5 & 0 & 22 & 7.3 & - & 3.9 & - & 7.3 & 7.5 & 2.7 \\
\hline 10076 & 8.4 & 8.6 & 36.5 & 0 & 15.1 & 7.9 & - & 4.2 & - & 7.9 & 8.3 & 3 \\
\hline 10077 & 5 & 2.3 & 26.4 & 0 & 18.8 & 10.2 & - & 7.2 & - & 12.5 & 13.1 & 4.6 \\
\hline 10078 & 7.7 & 4.6 & 27.8 & 0 & 26.6 & 5.7 & - & 3.5 & - & 5.5 & 9.8 & 8.8 \\
\hline 10079 & 5.3 & 2.6 & 9.7 & 0 & 3.8 & 29.2 & - & 18 & - & 19.4 & 11.1 & 0.9 \\
\hline 10080 & 5.2 & 2.5 & 11 & 0 & 4.5 & 28.5 & - & 17.8 & - & 18.9 & 10.7 & 0.8 \\
\hline 10081 & 3.3 & 0.3 & 6.7 & 0 & 2.4 & 26.8 & - & 22.1 & - & 24.1 & 13.3 & 1 \\
\hline 10082 & 3.7 & 0.6 & 7.4 & 0 & 6.5 & 32.4 & - & 19.2 & - & 18.7 & 10.5 & 0.9 \\
\hline 10083 & 6.9 & 1.1 & 5.5 & 0 & 1.6 & 44.9 & - & 33.9 & - & 5.7 & 0.4 & 0 \\
\hline 10084 & 7.1 & 1.3 & 4.9 & 0 & 1.8 & 43.6 & - & 35.1 & - & 5.7 & 0.4 & 0 \\
\hline 10085 & 4.2 & 0.6 & 2.2 & 0 & 1 & 37.4 & - & 42.8 & - & 11.4 & 0.3 & 0.1 \\
\hline 10086 & 5.9 & 1.8 & 3.9 & 0 & 1.5 & 43.6 & - & 36.7 & - & 5.9 & 0.5 & 0.1 \\
\hline 10087 & 4.3 & 2.4 & 8.7 & 0 & 9.4 & 26.6 & - & 16.8 & - & 20.5 & 9.9 & 1.4 \\
\hline 10088 & 4.4 & 3.1 & 8.1 & 0 & 5.2 & 28.1 & - & 17.7 & - & 21.4 & 10.5 & 1.6 \\
\hline 10089 & 3.4 & 0.8 & 7 & 0 & 6.9 & 33.8 & - & 17.8 & - & 19.6 & 9.5 & 1.1 \\
\hline 10090 & 3.2 & 0.8 & 8 & 0 & 8.1 & 29.5 & - & 20.4 & - & 21.4 & 8.1 & 0.6 \\
\hline 10091 & 6.6 & 1.1 & 4.1 & 0 & 2.5 & 64.3 & - & 19.4 & - & 1.4 & 0.6 & 0.1 \\
\hline 10092 & 6.6 & 1.1 & 4.8 & 0 & 2 & 64.7 & - & 18.9 & - & 1.3 & 0.5 & 0.1 \\
\hline 10093 & 4.7 & 0.7 & 2.7 & 0 & 1.8 & 60.2 & - & 27.8 & - & 1.8 & 0.3 & 0 \\
\hline 10094 & 6.2 & 1.3 & 2.8 & 0 & 2 & 51 & - & 33.4 & - & 2.7 & 0.4 & 0.1 \\
\hline 10095 & 57 & 13.8 & 4.1 & 0 & 1.3 & 2.5 & - & 2.6 & - & 6.6 & 8.1 & 4.1 \\
\hline 10096 & 55.1 & 12.9 & 3.7 & 0 & 2.1 & 2.9 & - & 3 & - & 7.3 & 8.8 & 4.2 \\
\hline 10097 & 60.5 & 8 & 0.3 & 0 & 0.9 & 5.7 & - & 4.6 & - & 6.7 & 11.2 & 2.2 \\
\hline 10098 & 65.3 & 7.8 & 0.5 & 0 & 1.2 & 3.9 & - & 2.7 & - & 4.1 & 8.5 & 6.1 \\
\hline 10099 & 39.1 & 27.2 & 11.4 & 0 & 1.3 & 3.2 & - & 2.6 & - & 5.4 & 8.6 & 1.1 \\
\hline 10100 & 38.8 & 28.3 & 10.2 & 0 & 1.6 & 2.9 & - & 2.6 & - & 6.5 & 8.4 & 0.7 \\
\hline 10101 & 2.5 & 2.8 & 6.6 & 0 & 7.6 & 21.7 & - & 19.9 & - & 21.3 & 12.9 & 4.7 \\
\hline 10102 & 2.5 & 2.8 & 6.6 & 0 & 7.6 & 21.7 & - & 19.9 & - & 21.3 & 12.9 & 4.7 \\
\hline 10103 & 0.9 & 0.1 & 0.3 & 0 & 1.9 & 23.1 & - & 25.6 & - & 26.9 & 17 & 4.1 \\
\hline 10104 & 0.9 & 0.1 & 0.3 & 0 & 1.9 & 23.1 & - & 25.6 & - & 26.9 & 17 & 4.1 \\
\hline 10105 & 0.6 & 0.3 & 0.7 & 0 & 2.2 & 20.6 & - & 22.1 & - & 29.2 & 21 & 3.4 \\
\hline 10106 & 0.6 & 0.3 & 0.7 & 0 & 2.2 & 20.6 & - & 22.1 & - & 29.2 & 21 & 3.4 \\
\hline 10107 & 3 & 2.9 & 4 & 0 & 2.7 & 22.3 & - & 21.3 & - & 23.7 & 14.8 & 5.3 \\
\hline 10108 & 1.2 & 0.4 & 0 & 0 & 1.2 & 24.8 & - & 26.9 & - & 26.9 & 13.2 & 5.3 \\
\hline 10109 & 1.4 & 0.2 & 0.6 & 0 & 1.1 & 23 & - & 26.8 & - & 28.7 & 14.4 & 3.7 \\
\hline
\end{tabular}




\begin{tabular}{|c|c|c|c|c|c|c|c|c|c|c|c|c|}
\hline MIN & 0 & 2 & 16 & 2 & 50 & 63 & 50 & 105 & 150 & 150 & 210 & 420 \\
\hline & 2 & 16 & 50 & 50 & 63 & 105 & 105 & 150 & 2000 & 210 & 420 & 2000 \\
\hline 10110 & 1.4 & 0.2 & 0.6 & 0 & 1.1 & 23 & - & 26.8 & - & 28.7 & 14.4 & 3.7 \\
\hline 10111 & 24.4 & 19.9 & 17.1 & 0 & 4.7 & 15.2 & - & 8.4 & - & 5.3 & 2.7 & 2.4 \\
\hline 10112 & 24.1 & 19.7 & 17.2 & 0 & 4.4 & 15.1 & - & 8.5 & - & 5.7 & 2.8 & 2.5 \\
\hline 10113 & 27.7 & 21.7 & 14.4 & 0 & 4.3 & 14.4 & - & 8.1 & - & 5.3 & 2.1 & 2.1 \\
\hline 10114 & 28.4 & 19.2 & 15.2 & 0 & 4.2 & 13.4 & - & 8.4 & - & 5.9 & 2.9 & 2.4 \\
\hline 10115 & 22.9 & 12.4 & 25.7 & 0 & 10.5 & 25 & - & 1.7 & - & 0.6 & 0.9 & 0.3 \\
\hline 10116 & 21.9 & 13.1 & 25.9 & 0 & 8 & 27.6 & - & 1.8 & - & 0.6 & 0.7 & 0.4 \\
\hline 10117 & 26.2 & 20.8 & 31.5 & 0 & 8.6 & 7.7 & - & 1.9 & - & 1.7 & 0.9 & 0.5 \\
\hline 10118 & 26.2 & 20.4 & 31.5 & 0 & 8.3 & 8.1 & - & 2.1 & - & 1.8 & 1 & 0.5 \\
\hline 10119 & 26.3 & 21.9 & 26.9 & 0 & 5.6 & 9.5 & - & 3.9 & - & 2.9 & 2.4 & 0.6 \\
\hline 10121 & 23.9 & 12.6 & 14.6 & 0 & 4.6 & 22 & - & 12.3 & - & 6.5 & 2.7 & 0.6 \\
\hline 10122 & 23.5 & 12.7 & 14.7 & 0 & 5.3 & 21.8 & - & 12.2 & - & 6.2 & 2.8 & 0.8 \\
\hline 10123 & 56.8 & 32.1 & 8.5 & 0 & - & - & 1.2 & 0.1 & - & 0 & 0.6 & 0.7 \\
\hline 10124 & 58.5 & 33.6 & 5.9 & 0 & - & - & 0.8 & 0.2 & - & 0.1 & 0.5 & 0.3 \\
\hline 10125 & 58.5 & 33.6 & 5.9 & 0 & - & - & 0.8 & 0.2 & - & 0.1 & 0.5 & 0.3 \\
\hline 10126 & 58.5 & 33.6 & 5.9 & 0 & - & - & 0.8 & 0.2 & - & 0.1 & 0.5 & 0.3 \\
\hline 10127 & 46.7 & 31.5 & 17 & 0 & - & - & 2.8 & 0.3 & - & 0.9 & 0.6 & 0.2 \\
\hline 10128 & 46.7 & 31.5 & 17 & 0 & - & - & 2.8 & 0.3 & - & 0.9 & 0.6 & 0.2 \\
\hline 10129 & 56.8 & 32.1 & 8.5 & 0 & - & - & 1.2 & 0.1 & - & 0 & 0.6 & 0.7 \\
\hline 10130 & 58.5 & 33.6 & 5.9 & 0 & - & - & 0.8 & 0.2 & - & 0.1 & 0.5 & 0.3 \\
\hline 10131 & 58.5 & 33.6 & 5.9 & 0 & - & - & 0.8 & 0.2 & - & 0.1 & 0.5 & 0.3 \\
\hline 10132 & 58.5 & 33.6 & 5.9 & 0 & - & - & 0.8 & 0.2 & - & 0.1 & 0.5 & 0.3 \\
\hline 10133 & - & - & - & 0 & - & - & - & - & - & - & - & - \\
\hline 10134 & - & - & - & 0 & - & - & - & - & - & - & - & - \\
\hline 10135 & 37.7 & 32.1 & 10.3 & 0 & 4.6 & 3.3 & - & 2.5 & - & 2 & 4.8 & 2.7 \\
\hline 10136 & - & - & - & 0 & - & - & - & - & - & - & - & - \\
\hline 10137 & 19.6 & 10.8 & 32.6 & 0 & 11.5 & 9.6 & - & 3.4 & - & 4.4 & 6.9 & 1.3 \\
\hline 10138 & - & - & - & 0 & - & - & - & - & - & - & - & - \\
\hline 10139 & - & - & - & 0 & - & - & - & - & - & - & - & - \\
\hline 10140 & 34.2 & 25.4 & 19.7 & 0 & 4.3 & 4.1 & - & 2.4 & - & 2.3 & 3 & 4.7 \\
\hline 10141 & 20.3 & 9.9 & 36.8 & 0 & 10.8 & 9.2 & - & 4.9 & - & 3.4 & 4.2 & 0.3 \\
\hline 10142 & - & - & - & 0 & - & - & - & - & - & - & - & - \\
\hline 10143 & - & - & - & 0 & - & - & - & - & - & - & - & - \\
\hline 10144 & 18.7 & 8.5 & 55.4 & 0 & 10.7 & 4.6 & - & 0.8 & - & 0.7 & 0.5 & 0.1 \\
\hline 10145 & 23.7 & 20 & 46.2 & 0 & 4 & 4 & - & 0.8 & - & 0.6 & 0.6 & 0.1 \\
\hline 10146 & 17.2 & 16.3 & 56.7 & 0 & 4.8 & 2 & - & 0.7 & - & 0.5 & 0.7 & 1 \\
\hline 10147 & 16.6 & 17 & 55.2 & 0 & 4.8 & 3.3 & - & 0.8 & - & 0.6 & 0.7 & 1.1 \\
\hline 10148 & 20 & 16.7 & 52.9 & 0 & 6.6 & 2.1 & - & 0.6 & - & 0.2 & 0.4 & 0.5 \\
\hline 10149 & 22.4 & 19.9 & 44.9 & 0 & 9.6 & 2.4 & - & 0.3 & - & 0.2 & 0.2 & 0.1 \\
\hline 10150 & 11.4 & 7 & 21.1 & 0 & 3.5 & 8.5 & - & 17.8 & - & 20.4 & 9.2 & 1.1 \\
\hline 10151 & 11.4 & 6.7 & 24.3 & 0 & 4 & 7.7 & - & 15.8 & - & 19.3 & 9.2 & 1.6 \\
\hline 10152 & 15.8 & 8.5 & 16 & 0 & 4.2 & 12.5 & - & 16.7 & - & 15 & 9.7 & 1.7 \\
\hline 10153 & 16.8 & 8.7 & 18.7 & 0 & 4.3 & 12.1 & - & 15.8 & - & 13.5 & 8.4 & 1.7 \\
\hline 10154 & 46.5 & 22.5 & -11.3 & 0 & 1.4 & 1.5 & - & 3.6 & - & 6.4 & 11.3 & 18 \\
\hline 10155 & 52 & 11.2 & -16.3 & 0 & 3.1 & 6.8 & - & 8.1 & - & 12.3 & 21.7 & 1.2 \\
\hline
\end{tabular}




\section{Bijlage 8 Gemeten dichtheden en Ksat, Staringbouwsteen en Gefitte MvG-parameters}

Tijdens de meting van de verzadigde waterdoorlatendheid hebben macroporiën, zoals wormgaten en wortelkanalen, grote invloed op de resultaten. Met de verdampingsmethode worden doorlatendheden afgeleid in het drukhoogtegebied $\mathrm{h}<-50 \mathrm{~cm}$, waardoor de invloed van de macroporiën onvoldoende wordt meegenomen. Het effect van macroporiën komt daarom ook onvoldoende tot uitdrukking in de Mualem-Van Genuchten-fit. De werkelijk gemeten verzadigde doorlatendheid Ksm kan daarom veel groter zijn dan de modelparameter Ksf.

$M I N$

$B / O$

$\theta r$

$\theta s$

a

$n$

$L$

Ksf

Ksm

$R d$
Monster Identificatie Nummer;

Staringreeks bouwsteen afgeleid van gemeten waarden. Bij ontbreken van meetwaarden is de bouwsteen afgeleid van veldgegevens. $B=$ Bovengrond; $O=$ Ondergrond;

Fitparameter: volumetrisch rest-vochtgehalte (Eng: residual water content); Fitparameter: volumetrisch verzadigd vochtgehalte (Eng: water content at saturation);

Fit-vormparameter;

Fit-vormparameter;

Fit-vormparameter;

Gefitte verzadigde waterdoorlatendheid (Eng: Fitted saturated water conductivity) Gemeten verzadigde waterdoorlatendheid (Eng: Measured saturated water conductivity)

Gemeten doge bulkdichtheid (Eng: Dry bulk density)

\begin{tabular}{|c|c|c|c|c|c|c|c|c|c|}
\hline MIN & $B / O$ & $\begin{array}{c}\text { Or } \\
\left(\mathrm{cm}^{3} \mathrm{~cm}^{-3}\right)\end{array}$ & $\begin{array}{c}\text { Os } \\
\left(\mathrm{cm}^{3} \mathrm{~cm}^{-3}\right)\end{array}$ & $\begin{array}{c}a \\
\left(\mathrm{~cm}^{-1}\right)\end{array}$ & $\begin{array}{c}n \\
(-)\end{array}$ & $\begin{array}{c}L \\
(-)\end{array}$ & $\begin{array}{c}\text { Ksf } \\
\left(m d^{-1}\right)\end{array}$ & $\begin{array}{l}\mathrm{Ksm} \\
\left(\mathrm{m} \mathrm{d}^{-1}\right)\end{array}$ & $\begin{array}{c}\text { Rd } \\
\left(\mathrm{g} \mathrm{cm}^{-3}\right)\end{array}$ \\
\hline 50 & B6 & P.M. & P.M. & P.M. & P.M. & P.M. & P.M. & P.M. & P.M. \\
\hline 60 & B7 & P.M. & P.M. & P.M. & P.M. & P.M. & P.M. & P.M. & P.M. \\
\hline 67 & B6 & P.M. & P.M. & P.M. & P.M. & P.M. & P.M. & P.M. & P.M. \\
\hline 1611 & B11 & P.M. & P.M. & P.M. & P.M. & P.M. & P.M. & P.M. & P.M. \\
\hline 1612 & 03 & P.M. & P.M. & P.M. & P.M. & P.M. & P.M. & P.M. & P.M. \\
\hline 1613 & 01 & P.M. & P.M. & P.M. & P.M. & P.M. & P.M. & P.M. & P.M. \\
\hline 1614 & B2 & P.M. & P.M. & P.M. & P.M. & P.M. & P.M. & P.M. & P.M. \\
\hline 1621 & B9 & P.M. & P.M. & P.M. & P.M. & P.M. & P.M. & P.M. & P.M. \\
\hline 1622 & 09 & P.M. & P.M. & P.M. & P.M. & P.M. & P.M. & P.M. & P.M. \\
\hline 1624 & $\mathrm{O} 2$ & P.M. & P.M. & P.M. & P.M. & P.M. & P.M. & P.M. & P.M. \\
\hline 1631 & B2 & P.M. & P.M. & P.M. & P.M. & P.M. & P.M. & P.M. & P.M. \\
\hline 1632 & B2 & P.M. & P.M. & P.M. & P.M. & P.M. & P.M. & P.M. & P.M. \\
\hline 1633 & B2 & P.M. & P.M. & P.M. & P.M. & P.M. & P.M. & P.M. & P.M. \\
\hline 1643 & B12 & P.M. & P.M. & P.M. & P.M. & P.M. & P.M. & P.M. & P.M. \\
\hline 1644 & 013 & P.M. & P.M. & P.M. & P.M. & P.M. & P.M. & P.M. & P.M. \\
\hline 1645 & 017 & P.M. & P.M. & P.M. & P.M. & P.M. & P.M. & P.M. & P.M. \\
\hline 1646 & 017 & P.M. & P.M. & P.M. & P.M. & P.M. & P.M. & P.M. & P.M. \\
\hline 1650 & 017 & P.M. & P.M. & P.M. & P.M. & P.M. & P.M. & P.M. & P.M. \\
\hline 1651 & B8 & P.M. & P.M. & P.M. & P.M. & P.M. & P.M. & P.M. & P.M. \\
\hline 1653 & B8 & P.M. & P.M. & P.M. & P.M. & P.M. & P.M. & P.M. & P.M. \\
\hline 1654 & 09 & P.M. & P.M. & P.M. & P.M. & P.M. & P.M. & P.M. & P.M. \\
\hline 1655 & 08 & P.M. & P.M. & P.M. & P.M. & P.M. & P.M. & P.M. & P.M. \\
\hline 1656 & 08 & P.M. & P.M. & P.M. & P.M. & P.M. & P.M. & P.M. & P.M. \\
\hline 1663 & B10 & P.M. & P.M. & P.M. & P.M. & P.M. & P.M. & P.M. & P.M. \\
\hline 1664 & B10 & P.M. & P.M. & P.M. & P.M. & P.M. & P.M. & P.M. & P.M. \\
\hline 1665 & 012 & P.M. & P.M. & P.M. & P.M. & P.M. & P.M. & P.M. & P.M. \\
\hline
\end{tabular}




\begin{tabular}{|c|c|c|c|c|c|c|c|c|c|}
\hline MIN & B/O & $\begin{array}{c}\text { Or } \\
\left(\mathrm{cm}^{3} \mathrm{~cm}^{-3}\right)\end{array}$ & $\begin{array}{c}\text { Os } \\
\left(\mathrm{cm}^{3} \mathrm{~cm}^{-3}\right)\end{array}$ & $\begin{array}{c}a \\
\left(\mathrm{~cm}^{-1}\right)\end{array}$ & $\begin{array}{l}n \\
(-)\end{array}$ & $\begin{array}{c}\text { L } \\
(-)\end{array}$ & $\begin{array}{c}\mathrm{Ksf} \\
\left(\mathrm{m} \mathrm{d}^{-1}\right)\end{array}$ & $\begin{array}{c}\mathrm{Ksm} \\
\left(\mathrm{m} \mathrm{d}^{-1}\right)\end{array}$ & $\begin{array}{c}\text { Rd } \\
\left(\mathrm{g} \mathrm{cm}^{-3}\right)\end{array}$ \\
\hline 1666 & 012 & P.M. & P.M. & P.M. & P.M. & P.M. & P.M. & P.M. & P.M. \\
\hline 1675 & B3 & P.M. & P.M. & P.M. & P.M. & P.M. & P.M. & P.M. & P.M. \\
\hline 1676 & $\mathrm{O} 3$ & P.M. & P.M. & P.M. & P.M. & P.M. & P.M. & P.M. & P.M. \\
\hline 1677 & 01 & P.M. & P.M. & P.M. & P.M. & P.M. & P.M. & P.M. & P.M. \\
\hline 1678 & B3 & P.M. & P.M. & P.M. & P.M. & P.M. & P.M. & P.M. & P.M. \\
\hline 1679 & B3 & P.M. & P.M. & P.M. & P.M. & P.M. & P.M. & P.M. & P.M. \\
\hline 1680 & $\mathrm{O} 2$ & P.M. & P.M. & P.M. & P.M. & P.M. & P.M. & P.M. & P.M. \\
\hline 1681 & O1 & P.M. & P.M. & P.M. & P.M. & P.M. & P.M. & P.M. & P.M. \\
\hline 1682 & $\mathrm{O} 1$ & 0.00543 & 0.32000 & 0.02048 & 1.99703 & 0.30119 & 24.8 & P.M. & 1.802 \\
\hline 1684 & B17 & 0.00000 & 0.71600 & 0.04155 & 1.12051 & -2.87908 & 18.1 & P.M. & 0.568 \\
\hline 1685 & B18 & 0.00000 & 0.79674 & 0.09362 & 1.12263 & -3.51408 & 74.1 & P.M. & 0.380 \\
\hline 1686 & 017 & 0.00000 & 0.89700 & 0.02038 & 1.20327 & -1.98451 & 25.0 & P.M. & 0.165 \\
\hline 1687 & 017 & 0.00000 & 0.91100 & 0.02602 & 1.26353 & -1.84625 & 19.4 & P.M. & 0.144 \\
\hline 1690 & 017 & 0.00000 & 0.88100 & 0.01749 & 1.20879 & -3.26990 & 14.2 & P.M. & 0.189 \\
\hline 1692 & B18 & 0.02539 & 0.69500 & 0.05014 & 1.11881 & -0.29234 & 55.1 & P.M. & 0.617 \\
\hline 1693 & B18 & 0.00000 & 0.71100 & 0.04390 & 1.11281 & -2.20740 & 24.4 & P.M. & 0.583 \\
\hline 1695 & 017 & 0.00000 & 0.88900 & 0.01629 & 1.21086 & -2.47187 & 11.3 & P.M. & 0.176 \\
\hline 1830 & B15 & 0.17530 & 0.61500 & 0.03295 & 1.51275 & -2.05291 & 3.5 & P.M. & 0.807 \\
\hline 10001 & O9 & 0.00000 & 0.45097 & 0.00817 & 1.18761 & 3.03778 & 1.6 & 259.8 & 1.480 \\
\hline 10002 & O9 & 0.00000 & 0.43764 & 0.00491 & 1.21335 & 5.90285 & 0.3 & 457.8 & 1.523 \\
\hline 10003 & $\mathrm{~B} 10$ & 0.00000 & 0.47600 & 0.01885 & 1.12940 & 3.96656 & 15.5 & 305.4 & 1.427 \\
\hline 10004 & B10 & 0.00000 & 0.47500 & 0.03887 & 1.10880 & -0.41479 & 21.4 & 699.9 & 1.474 \\
\hline 10005 & 010 & 0.00000 & 0.39504 & 0.00974 & 1.18987 & 14.00781 & 1.1 & 390.3 & 1.570 \\
\hline 10006 & 010 & 0.00000 & 0.39662 & 0.02803 & 1.13292 & 7.47520 & 42.6 & 1119.3 & 1.655 \\
\hline 10007 & B10 & 0.00000 & 0.42543 & 0.01199 & 1.14679 & 6.98344 & 7.2 & 1550.9 & 1.287 \\
\hline 10008 & B10 & 0.00000 & 0.45298 & 0.00392 & 1.18605 & 11.55716 & 0.8 & 1464.2 & 1.286 \\
\hline 10009 & B8 & 0.00000 & 0.40000 & 0.01350 & 1.17925 & 3.58488 & 2.1 & 1693.7 & 1.459 \\
\hline 10010 & B8 & 0.00000 & 0.41000 & 0.00641 & 1.22315 & 7.27132 & 1.5 & 795.0 & 1.523 \\
\hline 10011 & 010 & 0.04186 & 0.48000 & 0.05124 & 1.25526 & 3.97064 & 658.7 & 1249.5 & 1.431 \\
\hline 10012 & O9 & 0.00000 & 0.42758 & 0.01565 & 1.27456 & 4.36885 & 28.6 & 866.3 & 1.422 \\
\hline 10013 & 012 & 0.00000 & 0.55531 & 0.04547 & 1.09090 & 11.75086 & 58.3 & 1438.3 & 1.320 \\
\hline 10014 & 012 & 0.00000 & 0.51000 & 0.01573 & 1.10434 & 22.09820 & 8.8 & 1143.0 & 1.377 \\
\hline 10015 & 011 & 0.00000 & 0.43000 & 0.05164 & 1.08741 & 4.69637 & 77.5 & 1096.7 & 1.514 \\
\hline 10016 & 011 & 0.00000 & 0.44000 & 0.01464 & 1.13156 & -2.91267 & 3.8 & 1726.9 & 1.481 \\
\hline 10017 & 011 & 0.00000 & 0.58600 & 0.00942 & 1.19038 & 0.54000 & 1.7 & 154.9 & 1.095 \\
\hline 10018 & 010 & 0.00000 & 0.59204 & 0.00348 & 1.26083 & 5.32762 & 0.3 & 60.0 & 1.223 \\
\hline 10019 & 011 & 0.00000 & 0.46110 & 0.00218 & 1.25803 & 11.08953 & 0.0 & 265.9 & 1.487 \\
\hline 10020 & 011 & 0.00000 & 0.45473 & 0.02145 & 1.13654 & 13.49256 & 10.5 & 719.4 & 1.442 \\
\hline 10021 & $\mathrm{~B} 8$ & 0.00000 & 0.39206 & 0.00390 & 1.23531 & 11.18687 & 1.9 & 67.4 & 1.557 \\
\hline 10022 & B8 & 0.00000 & 0.41706 & 0.00777 & 1.25484 & 5.55766 & 7.5 & 1266.5 & 1.576 \\
\hline 10023 & B10 & 0.00000 & 0.43308 & 0.00450 & 1.22271 & 6.31143 & 0.1 & 82.1 & 1.419 \\
\hline 10024 & B10 & 0.00000 & 0.42503 & 0.00360 & 1.23555 & 6.74567 & 0.1 & 113.1 & 1.448 \\
\hline 10025 & 011 & 0.00000 & 0.41506 & 0.00307 & 1.16455 & 4.58496 & 0.1 & 2138.3 & 1.603 \\
\hline 10026 & 010 & 0.00000 & 0.43152 & 0.01294 & 1.11084 & -1.04859 & 1.7 & 180.5 & 1.522 \\
\hline 10027 & $\mathrm{~B} 10$ & 0.00000 & 0.45754 & 0.05032 & 1.09017 & 4.30006 & 46.4 & 275.8 & 1.576 \\
\hline 10028 & B10 & 0.00000 & 0.45592 & 0.03917 & 1.09076 & 0.00010 & 19.2 & 2080.4 & 1.562 \\
\hline 10029 & B2 & 0.09367 & 0.40174 & 0.02323 & 2.01810 & 0.21227 & 15.5 & 623.0 & 1.306 \\
\hline 10030 & B2 & 0.08250 & 0.43000 & 0.05894 & 1.61126 & -0.55958 & 48.9 & 764.8 & 1.425 \\
\hline 10031 & B2 & 0.09923 & 0.44814 & 0.03306 & 2.00000 & -1.13309 & 17.2 & 35.2 & 1.501 \\
\hline 10032 & B2 & 0.09630 & 0.39000 & 0.02515 & 1.80000 & -0.07687 & 10.5 & 230.5 & 1.316 \\
\hline 10033 & $\mathrm{~B} 1$ & 0.10457 & 0.47000 & 0.03393 & 2.20875 & 0.19383 & 90.1 & 1198.1 & 1.219 \\
\hline 10034 & $\mathrm{~B} 1$ & 0.10177 & 0.48000 & 0.03114 & 2.02032 & -0.06195 & 39.8 & 1226.2 & 1.302 \\
\hline 10035 & 05 & 0.05000 & 0.31400 & 0.02421 & 2.39704 & -0.72492 & 1.5 & 116.9 & 1.599 \\
\hline 10036 & O5 & 0.04000 & 0.34000 & 0.02383 & 1.70000 & -0.39297 & 6.7 & 112.5 & 1.675 \\
\hline 10037 & B1 & 0.11920 & 0.40600 & 0.01405 & 2.00000 & 1.89994 & 10.5 & 72.6 & 1.586 \\
\hline 10038 & B1 & 0.10742 & 0.41000 & 0.01386 & 2.00000 & 0.90009 & 11.0 & 349.3 & 1.470 \\
\hline 10039 & O5 & 0.03662 & 0.32211 & 0.03091 & 3.00000 & -0.99763 & 3.5 & 145.2 & 1.559 \\
\hline 10040 & 05 & 0.07143 & 0.30592 & 0.02529 & 3.00000 & -0.27530 & 24.4 & 83.7 & 1.625 \\
\hline 10041 & B7 & 0.13237 & 0.48000 & 0.01127 & 1.61245 & 5.55250 & 22.9 & 84.7 & 1.345 \\
\hline
\end{tabular}




\begin{tabular}{|c|c|c|c|c|c|c|c|c|c|}
\hline MIN & B/O & $\begin{array}{c}\text { Or } \\
\left(\mathrm{cm}^{3} \mathrm{~cm}^{-3}\right)\end{array}$ & $\begin{array}{c}\text { Os } \\
\left(\mathrm{cm}^{3} \mathrm{~cm}^{-3}\right)\end{array}$ & $\begin{array}{c}a \\
\left(\mathrm{~cm}^{-1}\right)\end{array}$ & $\begin{array}{c}n \\
(-)\end{array}$ & $\begin{array}{c}\mathrm{L} \\
(-)\end{array}$ & $\begin{array}{c}\text { Ksf } \\
\left(m d^{-1}\right)\end{array}$ & $\begin{array}{l}\mathrm{Ksm} \\
\left(\mathrm{m} \mathrm{d}^{-1}\right)\end{array}$ & $\begin{array}{c}\text { Rd } \\
\left(\mathrm{g} \mathrm{cm}^{-3}\right)\end{array}$ \\
\hline 10042 & B7 & 0.08035 & 0.49000 & 0.00882 & 1.47563 & 7.14408 & 11.8 & 540.1 & 1.397 \\
\hline 10043 & 01 & 0.03547 & 0.42000 & 0.00916 & 5.70528 & 0.23250 & 4.2 & 58.5 & 1.402 \\
\hline 10044 & $\mathrm{O} 1$ & 0.07063 & 0.46000 & 0.00924 & 5.80506 & -0.14665 & 9.4 & 14.7 & 1.403 \\
\hline 10045 & 05 & 0.00000 & 0.37982 & 0.02760 & 5.60757 & -0.97454 & 2.8 & 1253.2 & 1.511 \\
\hline 10046 & 05 & 0.04301 & 0.38000 & 0.03123 & 5.50000 & -0.72173 & 13.1 & 1161.9 & 1.474 \\
\hline 10047 & B4 & 0.08053 & 0.46505 & 0.01551 & 1.47465 & 6.38776 & 55.5 & 73.2 & 1.353 \\
\hline 10048 & B4 & 0.10289 & 0.45985 & 0.01300 & 1.71577 & 4.17493 & 32.9 & 191.1 & 1.351 \\
\hline 10049 & $\mathrm{O} 1$ & 0.04390 & 0.31000 & 0.01505 & 3.25131 & -0.04142 & 3.6 & 288.7 & 1.577 \\
\hline 10050 & 01 & 0.04155 & 0.34000 & 0.01440 & 2.68216 & 1.07965 & 3.9 & 40.2 & 1.552 \\
\hline 10051 & O5 & 0.05090 & 0.36106 & 0.03115 & 5.77708 & -0.74933 & 55.2 & 1238.0 & 1.528 \\
\hline 10052 & 05 & 0.02884 & 0.34506 & 0.02878 & 5.06571 & -0.76619 & 13.4 & 1239.6 & 1.580 \\
\hline 10053 & O5 & 0.02058 & 0.28668 & 0.03487 & 4.06436 & -0.85699 & 2.0 & 463.7 & 1.706 \\
\hline 10054 & 05 & 0.03203 & 0.31000 & 0.01939 & 5.02425 & -0.80455 & 4.0 & 670.9 & 1.706 \\
\hline 10055 & 01 & 0.04006 & 0.34568 & 0.02276 & 2.00815 & -0.01609 & 8.5 & 241.0 & 1.439 \\
\hline 10056 & 05 & 0.04739 & 0.37817 & 0.02610 & 2.55628 & 0.19813 & 21.5 & 665.0 & 1.482 \\
\hline 10057 & 01 & 0.03057 & 0.39500 & 0.02162 & 4.19063 & 0.36043 & 26.8 & 346.7 & 1.453 \\
\hline 10058 & 01 & 0.03398 & 0.38500 & 0.02222 & 4.74764 & -0.28077 & 31.4 & 177.4 & 1.442 \\
\hline 10059 & B7 & 0.00000 & 0.39581 & 0.00961 & 1.28679 & 6.33161 & 10.7 & 378.3 & 1.619 \\
\hline 10060 & B7 & 0.00000 & 0.40845 & 0.01076 & 1.29497 & 3.66133 & 12.9 & 174.5 & 1.521 \\
\hline 10061 & 010 & 0.00000 & 0.41794 & 0.00345 & 1.14236 & 3.85599 & 0.2 & 7.4 & 1.509 \\
\hline 10062 & 010 & 0.00000 & 0.42783 & 0.00337 & 1.14886 & 7.86871 & 0.2 & 84.0 & 1.548 \\
\hline 10063 & 09 & 0.00000 & 0.28112 & 0.02011 & 1.18728 & -0.83297 & 4.9 & 6.6 & 1.788 \\
\hline 10064 & 09 & 0.01064 & 0.30000 & 0.02357 & 1.21775 & 5.20563 & 34.7 & 18.4 & 1.686 \\
\hline 10065 & 05 & 0.04179 & 0.28465 & 0.04040 & 1.66275 & 0.25023 & 266.8 & 145.8 & 1.681 \\
\hline 10066 & 05 & 0.04804 & 0.30000 & 0.03991 & 1.84729 & -0.32695 & 105.6 & 340.9 & 1.639 \\
\hline 10067 & B2 & 0.04988 & 0.48364 & 0.00682 & 3.82395 & 0.83009 & 8.2 & 88.1 & 1.386 \\
\hline 10068 & B1 & 0.05723 & 0.48000 & 0.00827 & 3.06462 & 1.13611 & 30.2 & 107.3 & 1.396 \\
\hline 10069 & 05 & 0.03735 & 0.35000 & 0.02626 & 5.57686 & -0.84930 & 13.8 & 533.7 & 1.585 \\
\hline 10070 & 05 & 0.03403 & 0.34000 & 0.02541 & 4.81814 & -0.59989 & 22.6 & 1137.8 & 1.529 \\
\hline 10071 & O5 & 0.02593 & 0.34046 & 0.05212 & 3.05002 & -1.14280 & 8.9 & 2681.9 & 1.515 \\
\hline 10072 & 05 & 0.03845 & 0.33832 & 0.04611 & 4.61586 & -0.99905 & 35.1 & 2664.4 & 1.540 \\
\hline 10073 & B13 & 0.03867 & 0.38963 & 0.00790 & 1.41946 & 0.59596 & 2.5 & 1366.0 & 1.563 \\
\hline 10074 & B13 & 0.05640 & 0.37368 & 0.00362 & 1.61095 & 2.35212 & 1.0 & 1304.1 & 1.584 \\
\hline 10075 & $\mathrm{O} 4$ & 0.03506 & 0.40545 & 0.00749 & 1.50091 & 2.17638 & 9.9 & 441.2 & 1.297 \\
\hline 10076 & 014 & 0.09199 & 0.48704 & 0.00848 & 1.86335 & 0.55199 & 16.7 & 7.4 & 1.549 \\
\hline 10077 & $\mathrm{O} 4$ & 0.06479 & 0.39000 & 0.00721 & 1.73535 & 3.46845 & 34.3 & 22.5 & 1.506 \\
\hline 10078 & 04 & 0.08122 & 0.36123 & 0.00668 & 2.33889 & 1.91241 & 45.9 & 12.7 & 1.597 \\
\hline 10079 & B3 & 0.06864 & 0.41200 & 0.00832 & 1.77979 & 2.23693 & 10.4 & 1071.1 & 1.421 \\
\hline 10080 & B3 & 0.06264 & 0.43100 & 0.01478 & 1.55749 & 1.39485 & 41.6 & 26.6 & 1.412 \\
\hline 10081 & $\mathrm{O} 2$ & 0.06301 & 0.41000 & 0.01303 & 1.70901 & 0.91939 & 61.3 & 54.2 & 1.489 \\
\hline 10082 & $\mathrm{O} 2$ & 0.06511 & 0.38942 & 0.00810 & 1.88917 & 1.35751 & 17.0 & 101.4 & 1.514 \\
\hline 10083 & B2 & 0.08616 & 0.36000 & 0.01032 & 1.72436 & 2.36192 & 1.7 & 3.6 & 1.577 \\
\hline 10084 & B2 & 0.09644 & 0.36000 & 0.00920 & 1.76629 & 3.57349 & 2.3 & 7.5 & 1.645 \\
\hline 10085 & $\mathrm{O} 1$ & 0.07868 & 0.34853 & 0.01289 & 1.72354 & -0.27058 & 1.2 & 1.5 & 1.572 \\
\hline 10086 & $\mathrm{O} 2$ & 0.07822 & 0.34628 & 0.01385 & 1.62812 & -1.00120 & 1.0 & 1.1 & 1.681 \\
\hline 10087 & B2 & 0.00000 & 0.48743 & 0.00771 & 1.23704 & 8.84395 & 11.9 & 939.7 & 1.334 \\
\hline 10088 & B2 & 0.00000 & 0.48000 & 0.00617 & 1.23749 & 2.66946 & 3.5 & 14.5 & 1.336 \\
\hline 10089 & $\mathrm{O} 2$ & 0.00000 & 0.46000 & 0.00634 & 1.31115 & 1.74464 & 9.5 & 44.5 & 1.448 \\
\hline 10090 & $\mathrm{O} 2$ & 0.00000 & 0.43500 & 0.00399 & 1.46517 & 2.85044 & 3.0 & 13.3 & 1.513 \\
\hline 10091 & B2 & 0.09501 & 0.37100 & 0.00911 & 2.45040 & 0.93968 & 1.7 & 79.7 & 1.575 \\
\hline 10092 & B2 & 0.09085 & 0.37000 & 0.00952 & 2.23276 & 1.45723 & 3.5 & 81.8 & 1.550 \\
\hline 10093 & 01 & 0.10650 & 0.38815 & 0.00922 & 2.04004 & 4.25928 & 6.4 & 16.7 & 1.604 \\
\hline 10094 & $\mathrm{O} 2$ & 0.11337 & 0.37800 & 0.00970 & 2.99915 & 1.10888 & 5.7 & 78.4 & 1.559 \\
\hline 10095 & B12 & 0.00000 & 0.71000 & 0.02002 & 1.13767 & 6.32906 & 6.4 & 823.5 & 0.650 \\
\hline 10096 & B12 & 0.00000 & 0.71000 & 0.02811 & 1.11788 & 18.58667 & 156.7 & 681.0 & 0.645 \\
\hline 10097 & 013 & 0.00000 & 0.79000 & 0.01434 & 1.10725 & 24.28568 & 63.8 & 204.5 & 0.641 \\
\hline 10098 & 013 & 0.00000 & 0.78000 & 0.02600 & 1.08742 & 13.24121 & 42.8 & 12.9 & 0.519 \\
\hline 10099 & B11 & 0.00000 & 0.65840 & 0.01294 & 1.11265 & 8.29825 & 19.2 & 54.7 & 0.862 \\
\hline 10100 & B11 & 0.00000 & 0.62980 & 0.02084 & 1.10076 & 16.87646 & 192.1 & 107.0 & 0.875 \\
\hline
\end{tabular}




\begin{tabular}{|c|c|c|c|c|c|c|c|c|c|}
\hline MIN & $\mathrm{B} / \mathrm{O}$ & $\begin{array}{c}\text { Or } \\
\left(\mathrm{cm}^{3} \mathrm{~cm}^{-3}\right)\end{array}$ & $\begin{array}{c}\text { Os } \\
\left(\mathrm{cm}^{3} \mathrm{~cm}^{-3}\right)\end{array}$ & $\begin{array}{c}a \\
\left(\mathrm{~cm}^{-1}\right)\end{array}$ & $\begin{array}{c}n \\
(-)\end{array}$ & $\begin{array}{l}\mathrm{L} \\
(-)\end{array}$ & $\begin{array}{c}K s f \\
\left(\mathrm{~m} \mathrm{~d}^{-1}\right)\end{array}$ & $\begin{array}{c}\mathrm{Ksm} \\
\left(\mathrm{m} \mathrm{d}^{-1}\right)\end{array}$ & $\begin{array}{c}\text { Rd } \\
\left(\mathrm{g} \mathrm{cm}^{-3}\right)\end{array}$ \\
\hline 10101 & B2 & 0.14863 & 0.46094 & 0.01254 & 2.14897 & 0.79480 & 9.5 & 21.9 & 1.355 \\
\hline 10102 & $\mathrm{~B} 2$ & - & - & - & - & - & - & - & 1.475 \\
\hline 10103 & $\mathrm{O} 1$ & 0.04235 & 0.31038 & 0.01425 & 2.56280 & 0.53422 & 20.2 & 54.4 & 1.711 \\
\hline 10104 & O1 & - & - & - & - & - & - & 36.9 & 1.662 \\
\hline 10105 & $\mathrm{O} 1$ & 0.02281 & 0.28564 & 0.01034 & 2.88488 & 1.60622 & 11.2 & 45.1 & 1.754 \\
\hline 10106 & $\mathrm{O} 1$ & - & - & - & - & - & - & - & 1.778 \\
\hline 10107 & B1 & 0.03072 & 0.44793 & 0.02151 & 1.22610 & 4.73126 & 58.6 & 106.0 & 1.399 \\
\hline 10108 & $\mathrm{O} 1$ & 0.06593 & 0.32378 & 0.00778 & 3.33731 & 0.44457 & 6.9 & 24.9 & 1.705 \\
\hline 10109 & B1 & 0.04140 & 0.32597 & 0.01286 & 3.89207 & -0.20809 & 7.8 & 416.2 & 1.726 \\
\hline 10110 & B1 & - & - & - & - & - & - & 167.4 & - \\
\hline 10111 & B9 & 0.00000 & 0.42978 & 0.02015 & 1.08240 & -17.99725 & 0.9 & 22.4 & 1.530 \\
\hline 10112 & B9 & 0.00000 & 0.45068 & 0.01953 & 1.08041 & 0.00010 & 13.4 & 8.1 & 1.457 \\
\hline 10113 & 011 & 0.19501 & 0.40182 & 0.01674 & 1.19521 & -2.86683 & 0.3 & 17.3 & 1.597 \\
\hline 10114 & 011 & 0.24372 & 0.39496 & 0.01534 & 1.57964 & -2.00000 & 0.1 & 86.1 & 1.585 \\
\hline 10115 & B9 & 0.00000 & 0.42588 & 0.01867 & 1.08281 & -12.87140 & 2.3 & 177.2 & 1.521 \\
\hline 10116 & B9 & 0.00000 & 0.42824 & 0.03007 & 1.08650 & 0.00010 & 14.0 & 201.6 & 1.493 \\
\hline 10117 & $\mathrm{~B} 10$ & 0.00000 & 0.47884 & 0.06093 & 1.08819 & 0.00010 & 182.6 & 437.2 & 1.538 \\
\hline 10118 & B10 & 0.00000 & 0.44063 & 0.02144 & 1.07769 & 0.00010 & 16.3 & 1231.8 & 1.546 \\
\hline 10119 & 011 & 0.00000 & 0.49919 & 0.07094 & 1.07389 & 0.00010 & 185.7 & 654.0 & 1.459 \\
\hline 10121 & B9 & 0.00000 & 0.46068 & 0.13179 & 1.05774 & -13.77067 & 56.0 & 1314.0 & 1.468 \\
\hline 10122 & B9 & 0.25430 & 0.47738 & 0.04855 & 1.27124 & -3.80759 & 1.2 & 1733.0 & 1.496 \\
\hline 10123 & $\mathrm{~B} 12$ & 0.24784 & 0.55460 & 0.00464 & 1.30321 & 0.73245 & 0.1 & 590.2 & 1.134 \\
\hline 10124 & B12 & 0.00000 & 0.50257 & 0.01740 & 1.06394 & -9.81823 & 1.3 & 0.2 & 1.134 \\
\hline 10125 & 013 & 0.00000 & 0.57692 & 0.01368 & 1.07267 & -10.00000 & 0.9 & 0.5 & 1.201 \\
\hline 10126 & 013 & 0.00000 & 0.56568 & 0.01722 & 1.05880 & 0.00010 & 3.0 & 2.3 & 1.182 \\
\hline 10127 & 012 & 0.00000 & 0.63774 & 0.00281 & 1.14292 & -1.99990 & 1.0 & 391.3 & 0.926 \\
\hline 10128 & 012 & 0.00000 & 0.70341 & 0.00567 & 1.13463 & 0.00010 & 2.0 & 202.9 & 0.777 \\
\hline 10129 & B12 & 0.24856 & 0.55622 & 0.00377 & 1.25964 & -2.98076 & 0.0 & 356.1 & 1.166 \\
\hline 10130 & B12 & 0.00000 & 0.50643 & 0.00734 & 1.08870 & 0.00010 & 0.4 & 6.3 & 1.317 \\
\hline 10131 & B12 & 0.00000 & 0.51613 & 0.01223 & 1.07068 & 0.00000 & 1.4 & 0.0 & 1.352 \\
\hline 10132 & 013 & 0.10483 & 0.55691 & 0.00664 & 1.08497 & -20.00000 & 0.1 & 2.2 & 1.209 \\
\hline 10133 & $\mathrm{O} 2$ & 0.03122 & 0.30802 & 0.00917 & 4.38651 & 0.00010 & 2.3 & - & 1.788 \\
\hline 10134 & $\mathrm{O} 5$ & 0.03539 & 0.36683 & 0.02135 & 7.23720 & 0.00010 & 101.4 & - & 1.751 \\
\hline 10135 & 017 & 0.00000 & 0.78184 & 0.00483 & 1.30564 & 0.00010 & 30.2 & 89.2 & 0.410 \\
\hline 10136 & $\mathrm{O} 2$ & 0.06551 & 0.32482 & 0.01216 & 2.29519 & 0.18043 & 2.5 & - & 1.747 \\
\hline 10137 & 014 & 0.00000 & 0.68073 & 0.00129 & 1.54111 & 7.00000 & 1.1 & 0.3 & 0.729 \\
\hline 10138 & $\mathrm{O} 2$ & 0.00000 & 0.37555 & 0.00209 & 1.49091 & 0.00010 & 2.3 & - & 1.723 \\
\hline 10139 & B2 & 0.08358 & 0.36000 & 0.02428 & 2.10385 & 0.96677 & 26.3 & - & 1.538 \\
\hline 10140 & 017 & 0.00000 & 0.75821 & 0.00170 & 1.44551 & 0.00010 & 4.6 & 1789.9 & 0.433 \\
\hline 10141 & 014 & 0.17973 & 0.76789 & 0.00326 & 1.55565 & 0.00010 & 4.0 & 2.8 & 0.471 \\
\hline 10142 & $\mathrm{O} 3$ & 0.11526 & 0.30592 & 0.00527 & 1.39142 & 2.74222 & 0.4 & - & 1.791 \\
\hline 10143 & 014 & 0.12249 & 0.32049 & 0.00248 & 3.00199 & 0.38588 & 0.8 & - & 1.861 \\
\hline 10144 & 014 & 0.00000 & 0.36030 & 0.00086 & 1.30062 & 2.00000 & 0.1 & 0.8 & 1.827 \\
\hline 10145 & 015 & 0.00000 & 0.44468 & 0.00048 & 1.44603 & 2.00000 & 0.2 & - & 1.591 \\
\hline 10146 & B14 & 0.00000 & 0.41386 & 0.00960 & 1.18493 & 8.55552 & 14.1 & 34.5 & 1.615 \\
\hline 10147 & B14 & 0.00000 & 0.40674 & 0.00683 & 1.19621 & 20.00000 & 26.4 & 133.5 & 1.627 \\
\hline 10148 & 015 & 0.00000 & 0.39600 & 0.00407 & 1.20298 & 0.00010 & 0.6 & 0.3 & 1.664 \\
\hline 10149 & 015 & 0.10710 & 0.44200 & 0.01830 & 1.40190 & 5.45084 & 62.6 & 0.7 & 1.652 \\
\hline 10150 & $\mathrm{O} 4$ & 0.09864 & 0.44300 & 0.02189 & 1.31428 & 6.77201 & 126.4 & 114.9 & 1.434 \\
\hline 10151 & O4 & 0.01998 & 0.33200 & 0.00598 & 1.82541 & 5.65232 & 5.8 & 82.8 & 1.765 \\
\hline 10152 & B4 & 0.00000 & 0.50737 & 0.01233 & 1.13971 & 10.00000 & 7.5 & 28.8 & 1.484 \\
\hline 10153 & B4 & 0.00000 & 0.52650 & 0.01170 & 1.15687 & 4.57300 & 5.5 & 1.7 & 1.326 \\
\hline 10154 & B16 & 0.07809 & 0.89000 & 0.03967 & 1.35116 & 5.04990 & 1381.2 & 1851.8 & 0.158 \\
\hline 10155 & B16 & 0.00000 & 0.88500 & 0.08839 & 1.21971 & 4.78513 & 1149.7 & 2444.0 & 0.173 \\
\hline
\end{tabular}




\section{Bijlage 9 Grafieken waterretentie en -doorlatendheid}

In de figuren van deze bijlage zijn links de retentie- en rechts de waterdoorlatendheidskarakteristieken gegeven. Duplomonsters zijn steeds samen in 1 grafiek weergegeven. De data (blauwe kruisjes ( $1^{\mathrm{e}}$ monster) en rode open vierkantjes (duplo monster) zijn afkomstig uit de prefit van de verdampingsmethode; het getal in de legenda verwijst naar het Monster Identificatie Nummer (MIN) van het betreffende monster. Verder zijn in de retentie-karakteristiek nog extra meetpunten opgenomen vanuit de zandbak- en drukpanmethode (groene stippen). In de doorlatendheidskarakteristiek zijn extra meetpunten opgenomen van de apart gemeten verzadigde waterdoorlatendheid (groene stippen). De retentie- en doorlatendheids-karakteristieken zijn per monster gefit met een uni-modale Mualem-Van Genuchten-fit. Dat betekent dat soms concessies zijn gedaan in de retentiecurve om de doorlatendheidscurve beter te kunnen fitten en vice versa. Merk op dat de assen voor de drukhoogte $h$ en de doorlatendheid $K$ logaritmisch zijn weergegeven.
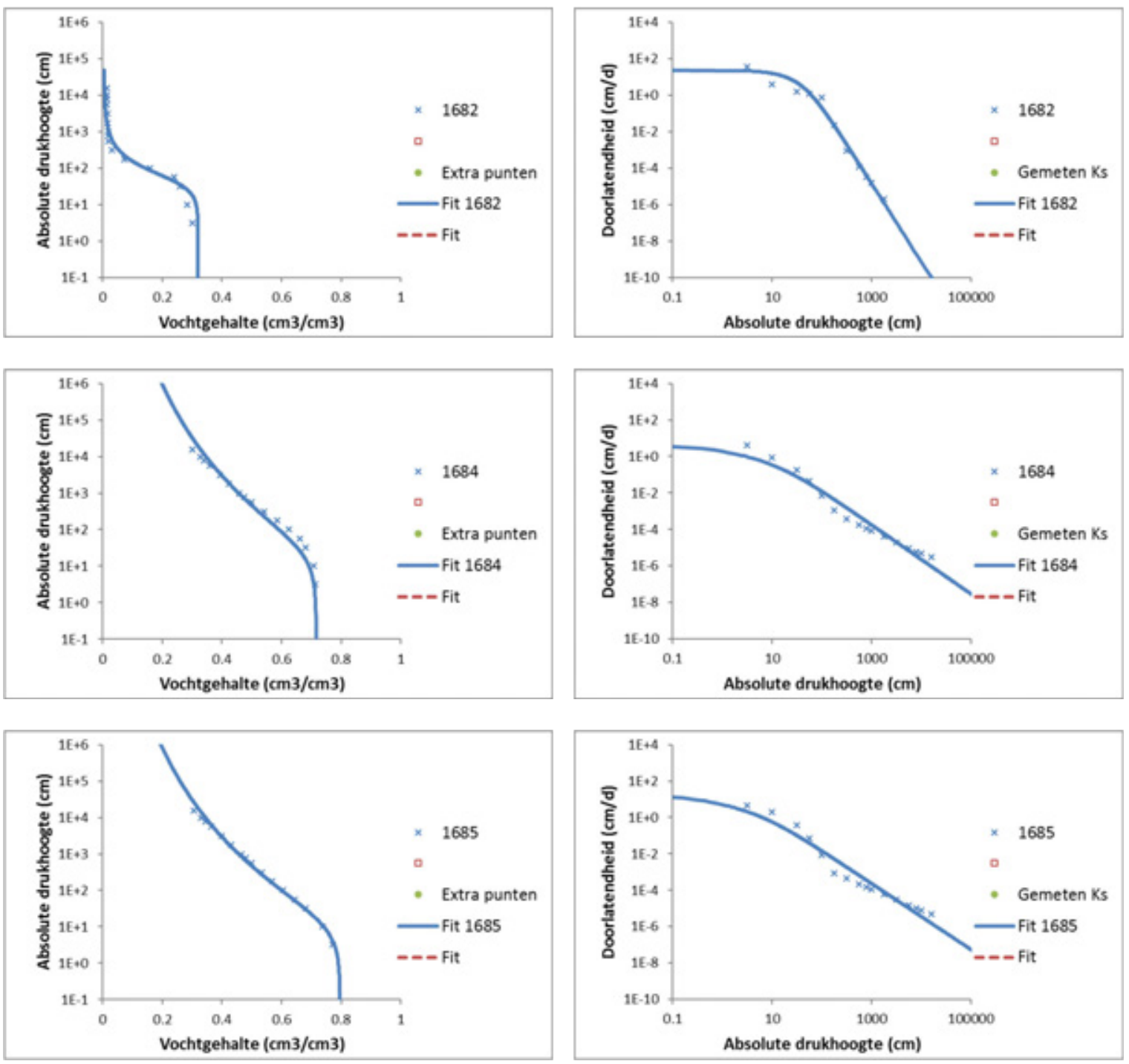

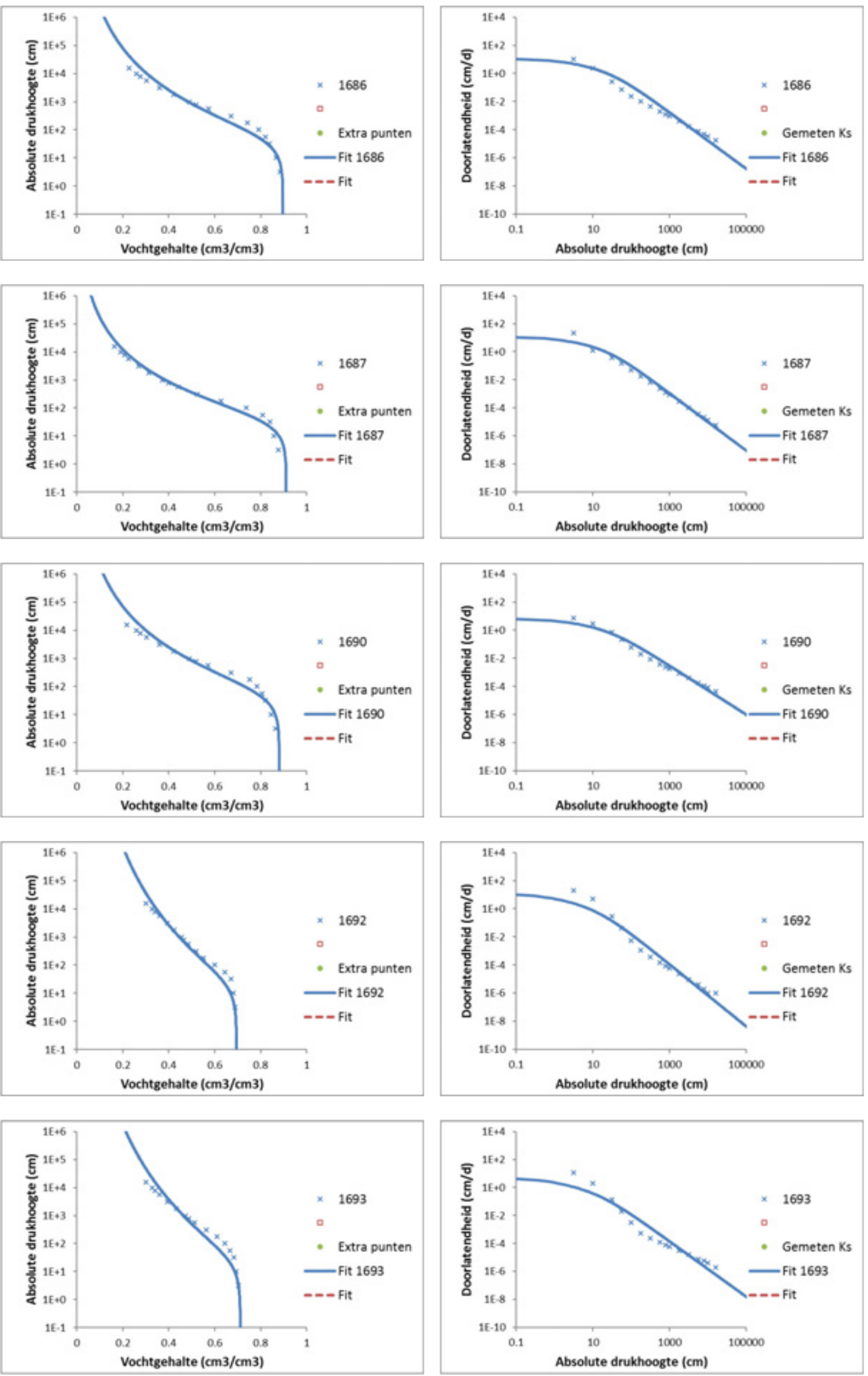

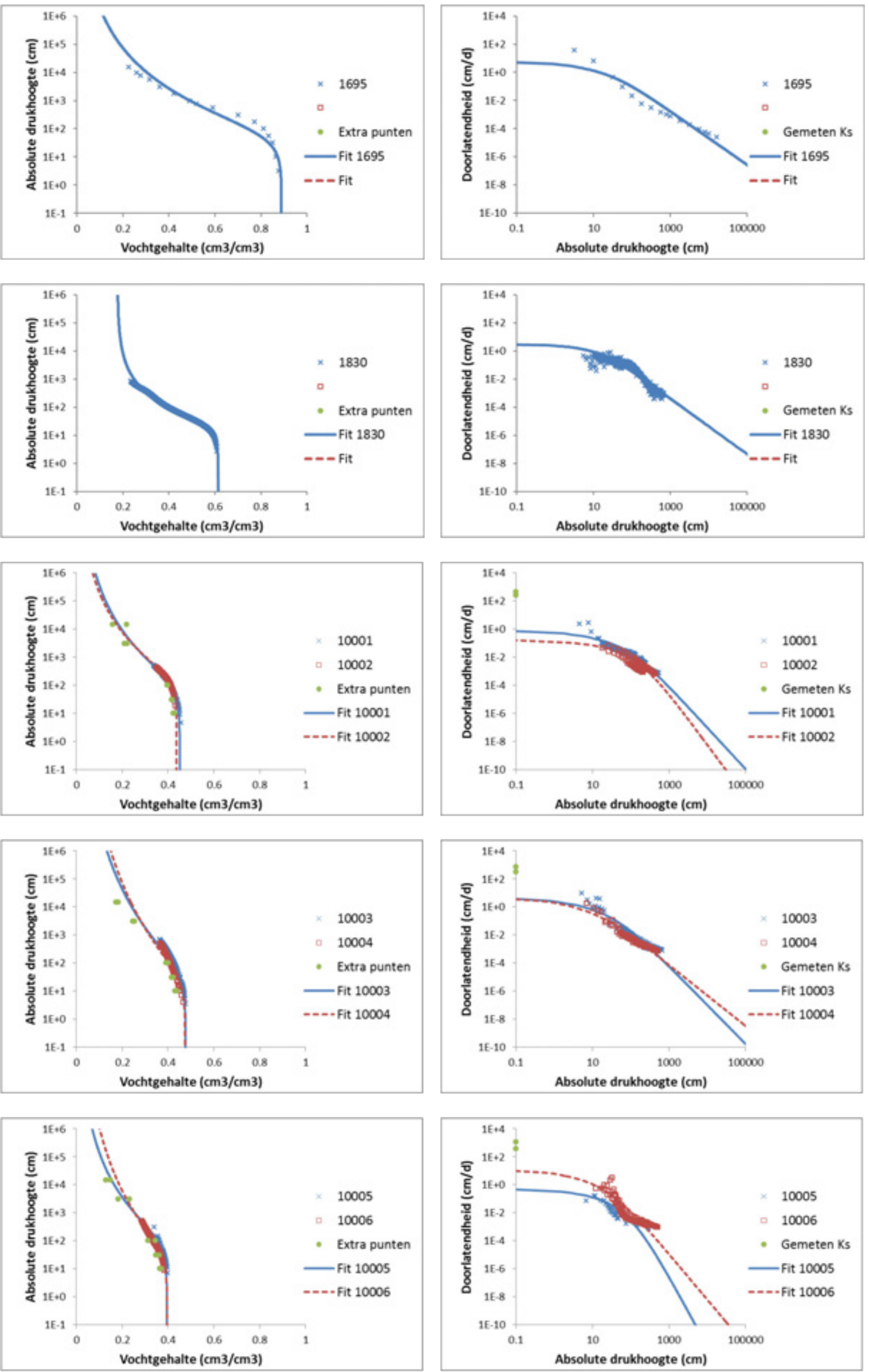

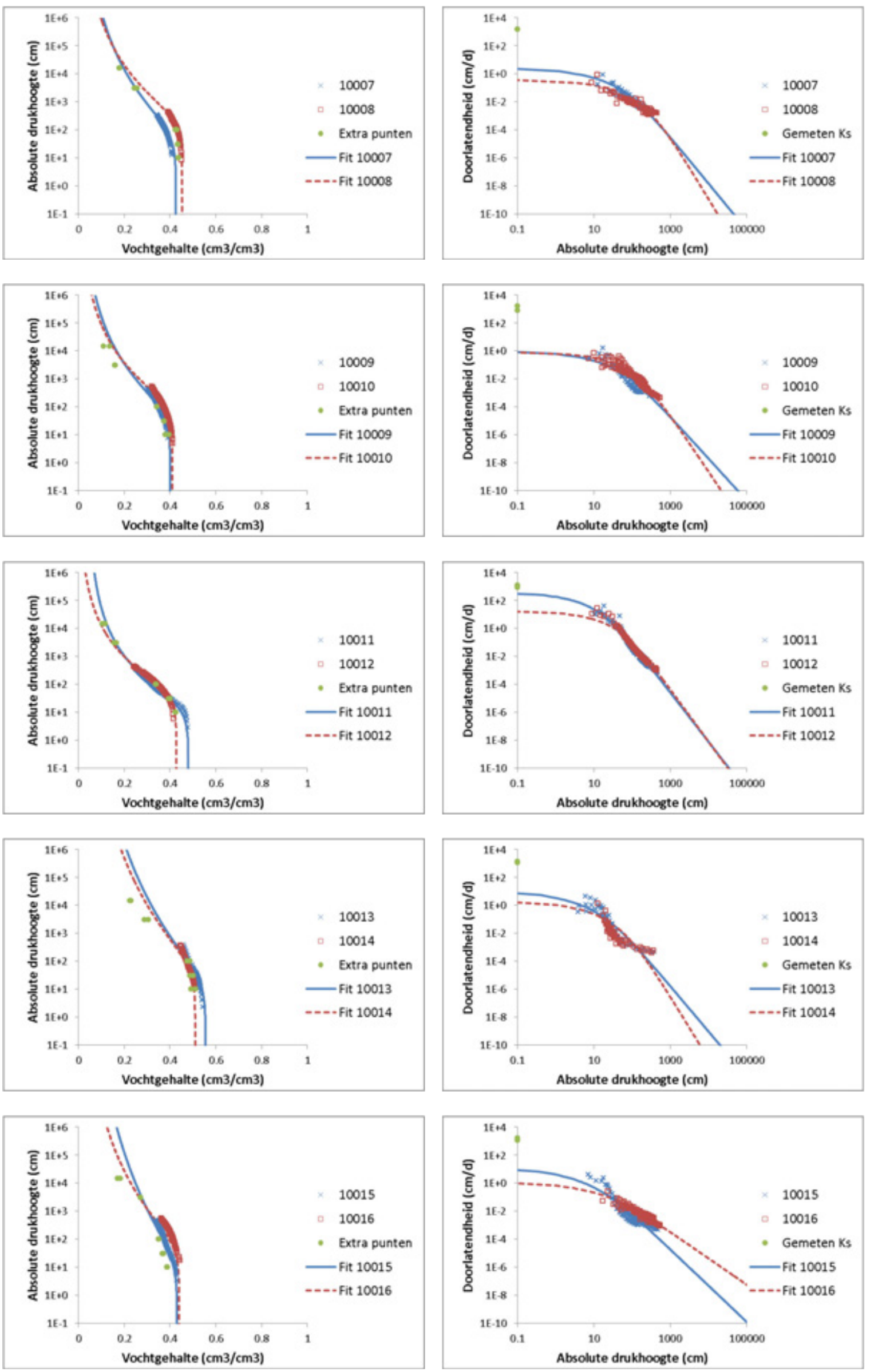

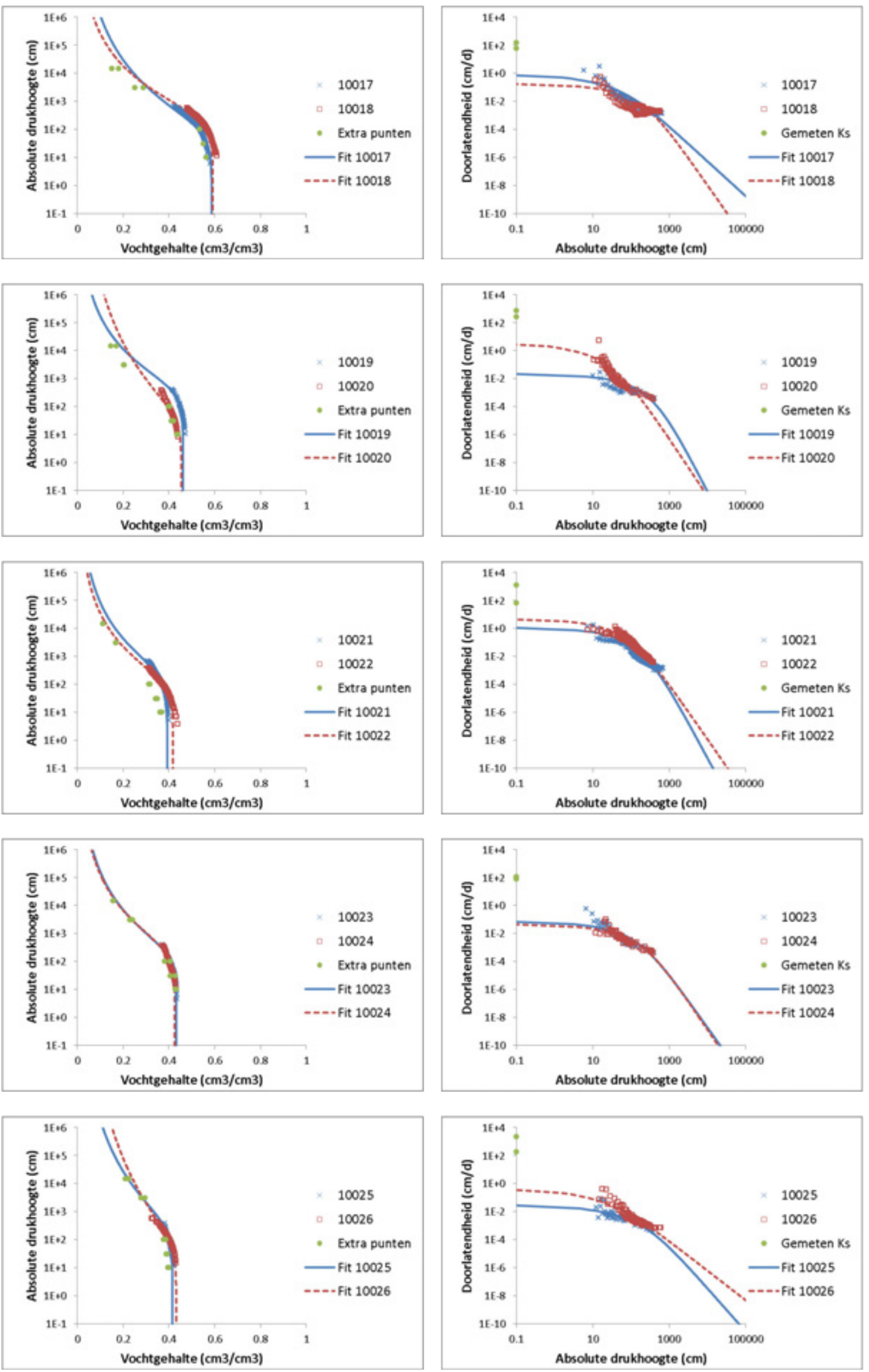

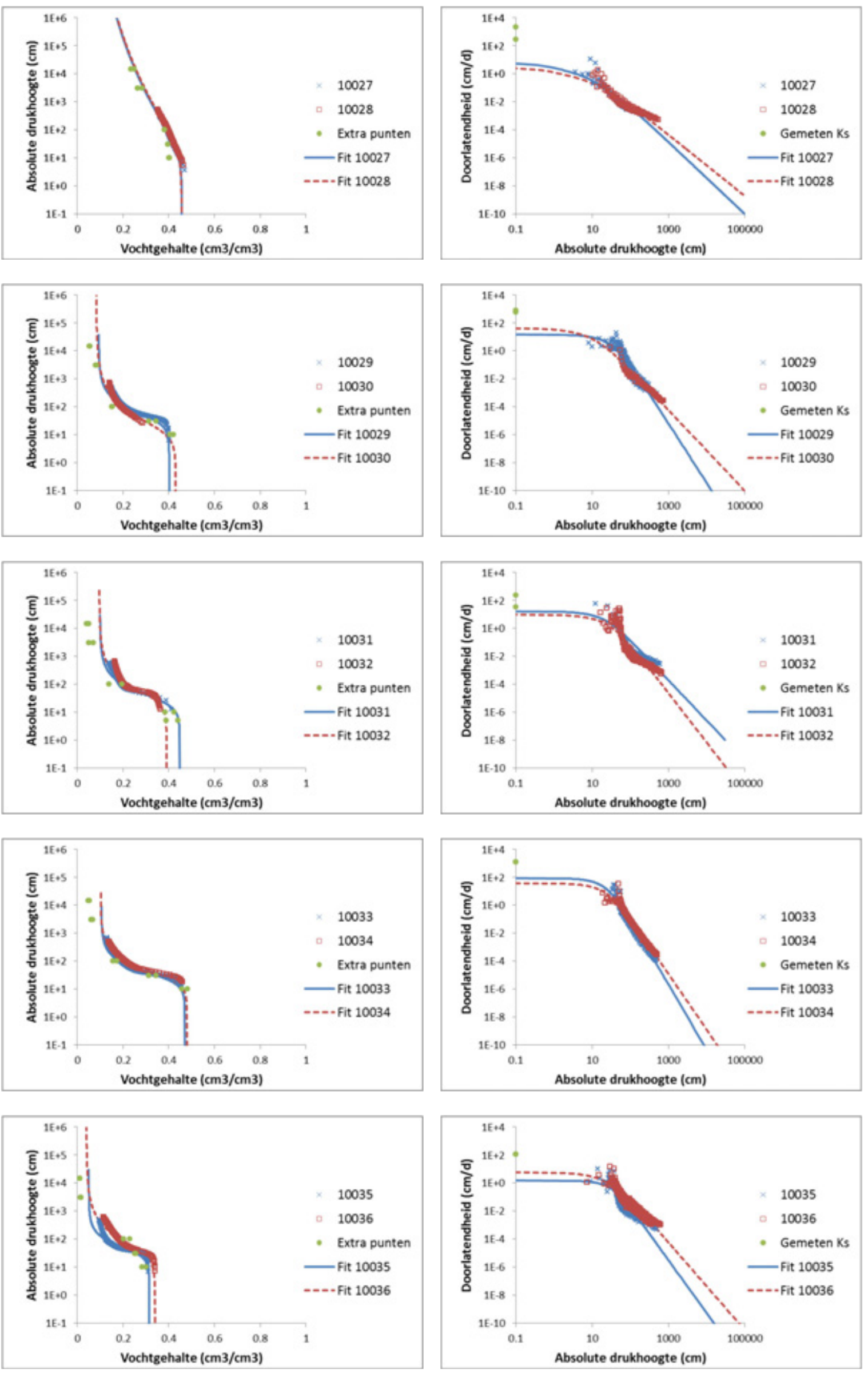

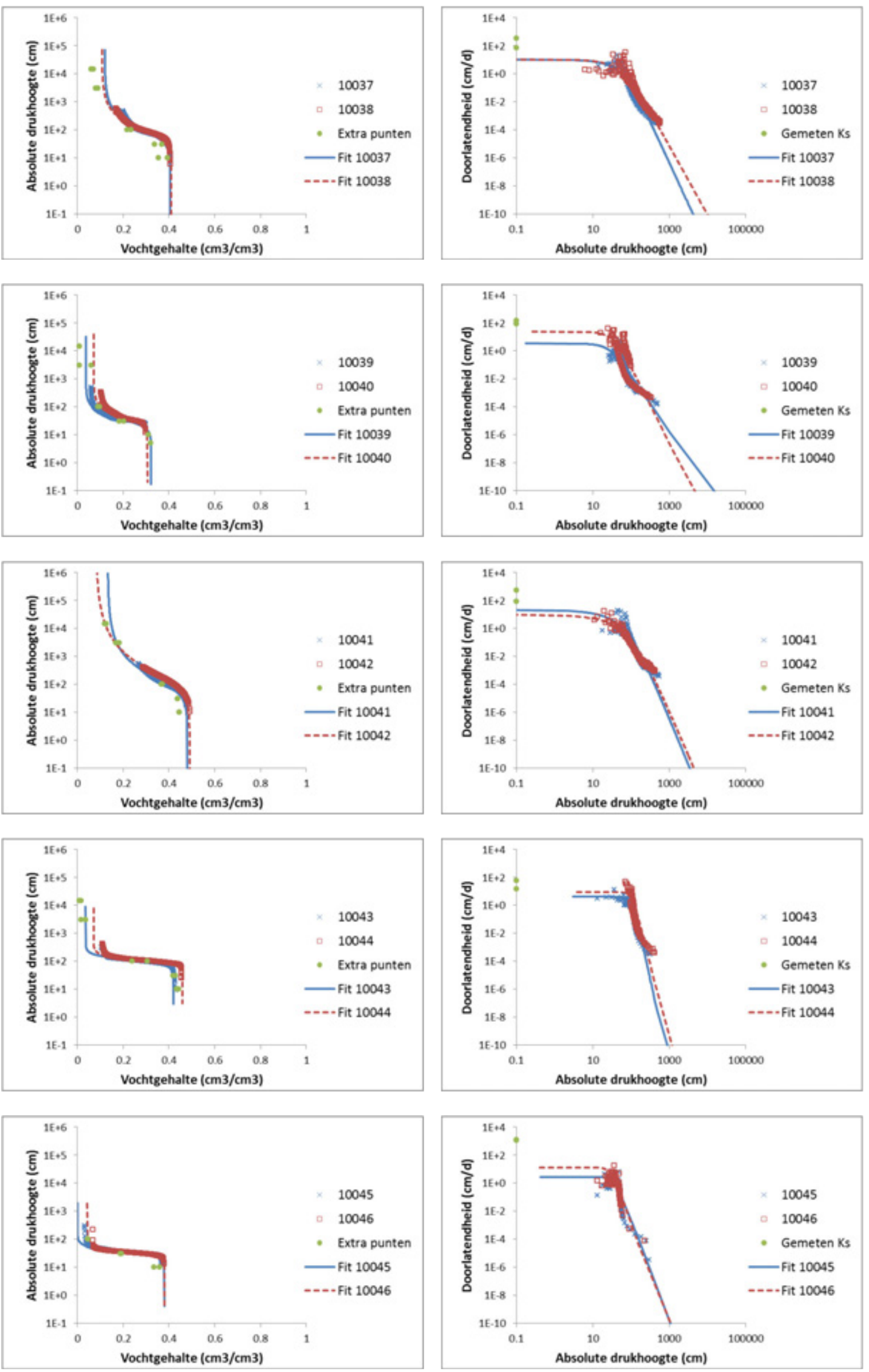

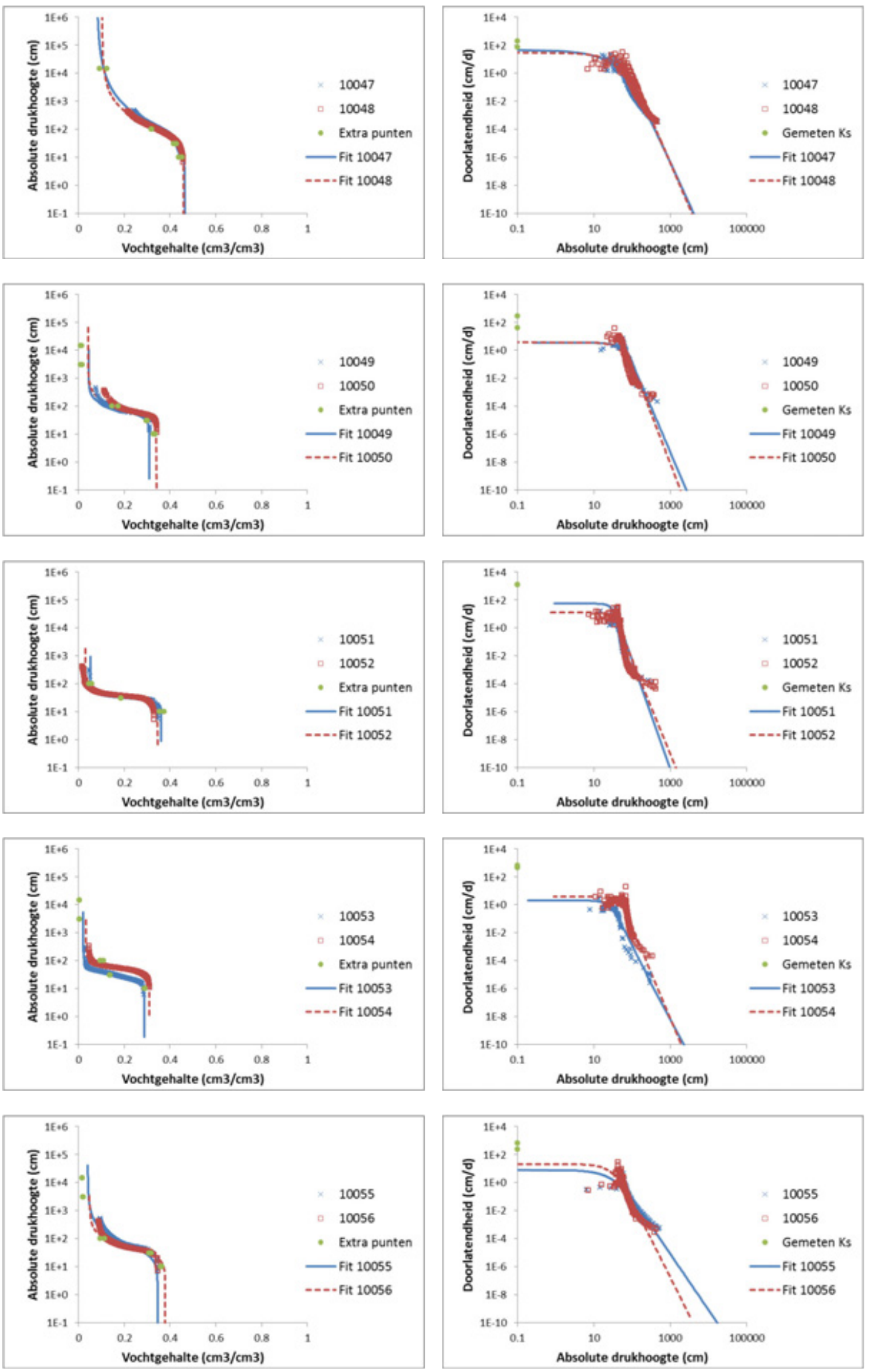

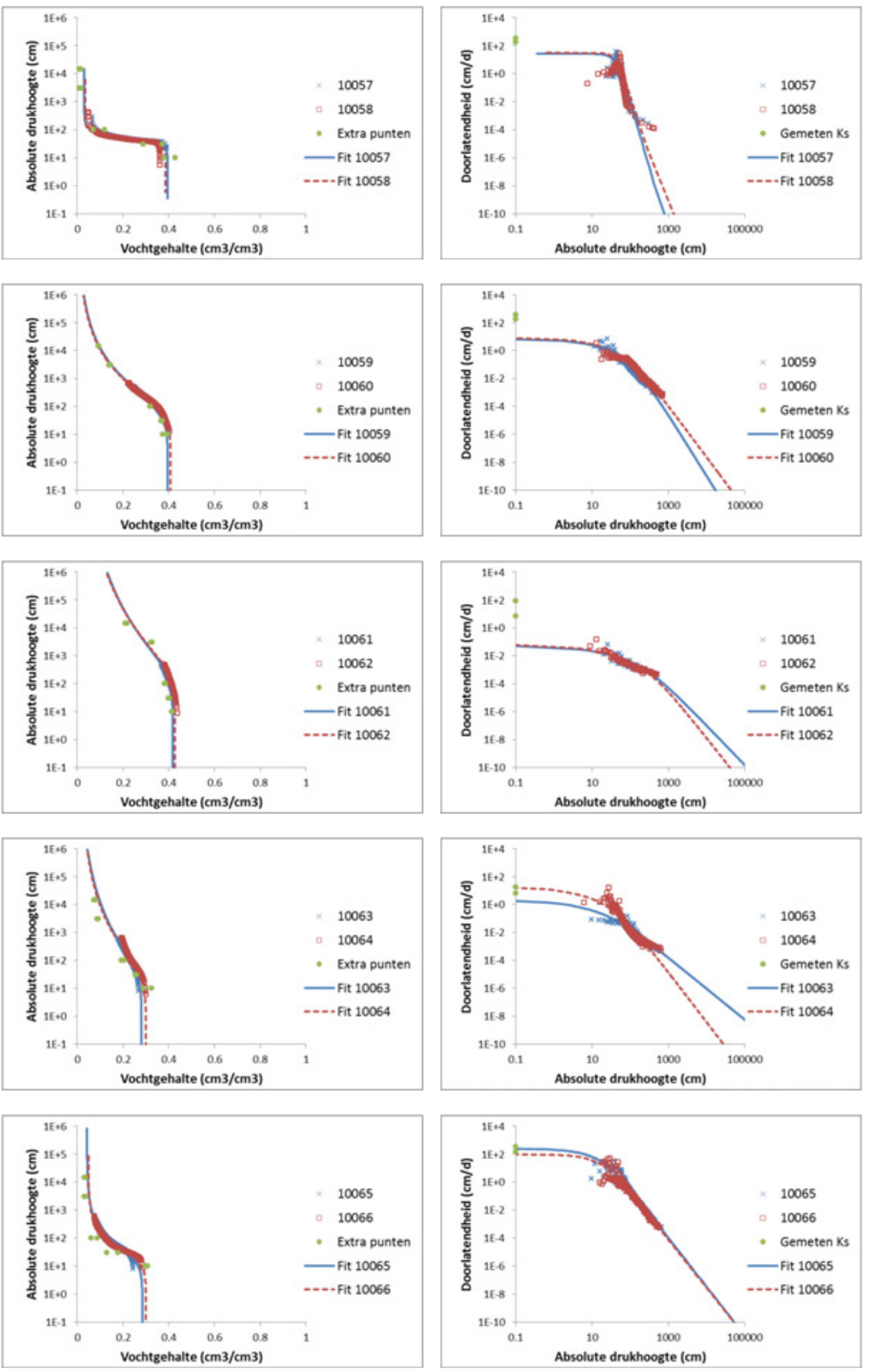

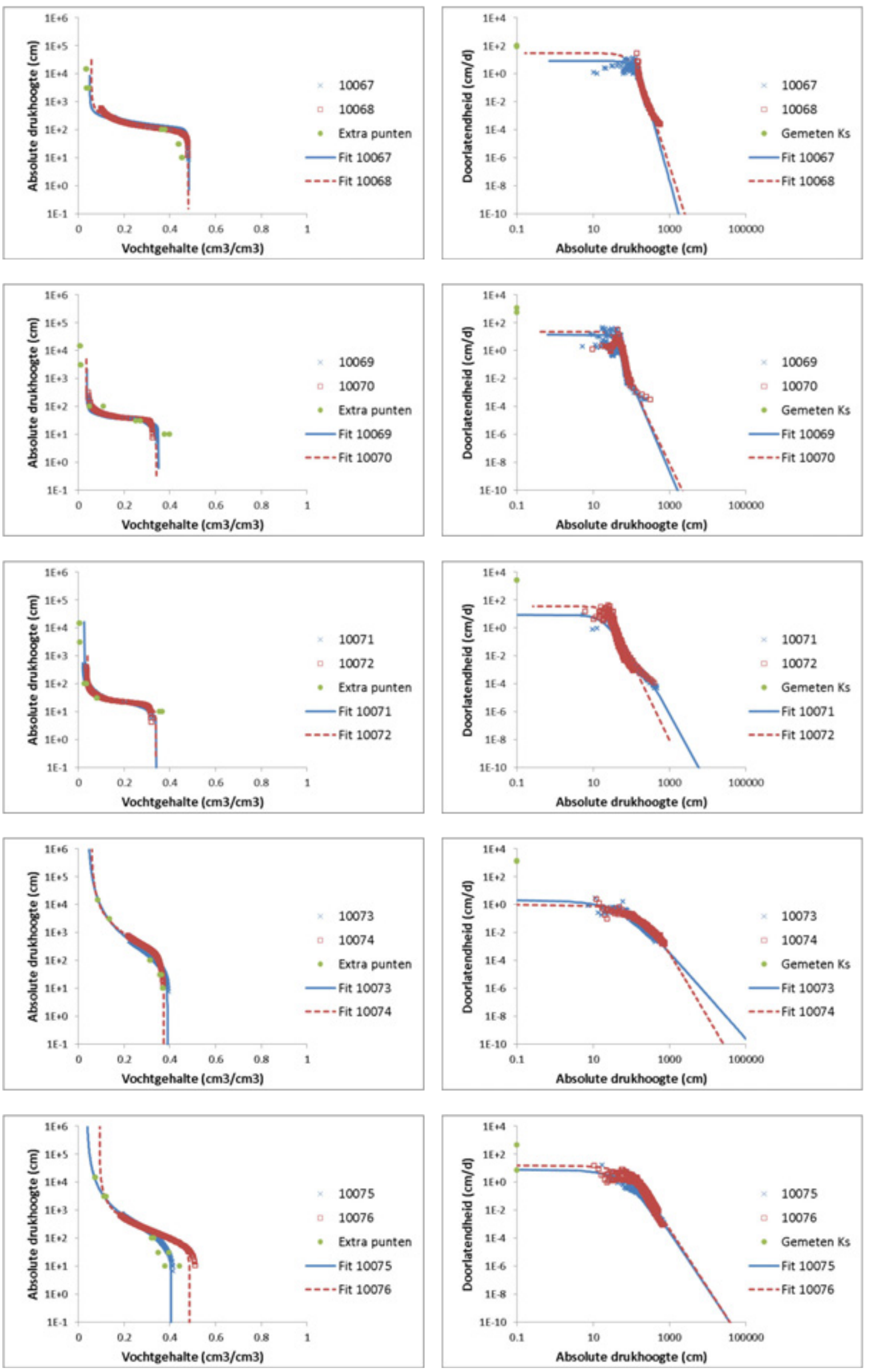

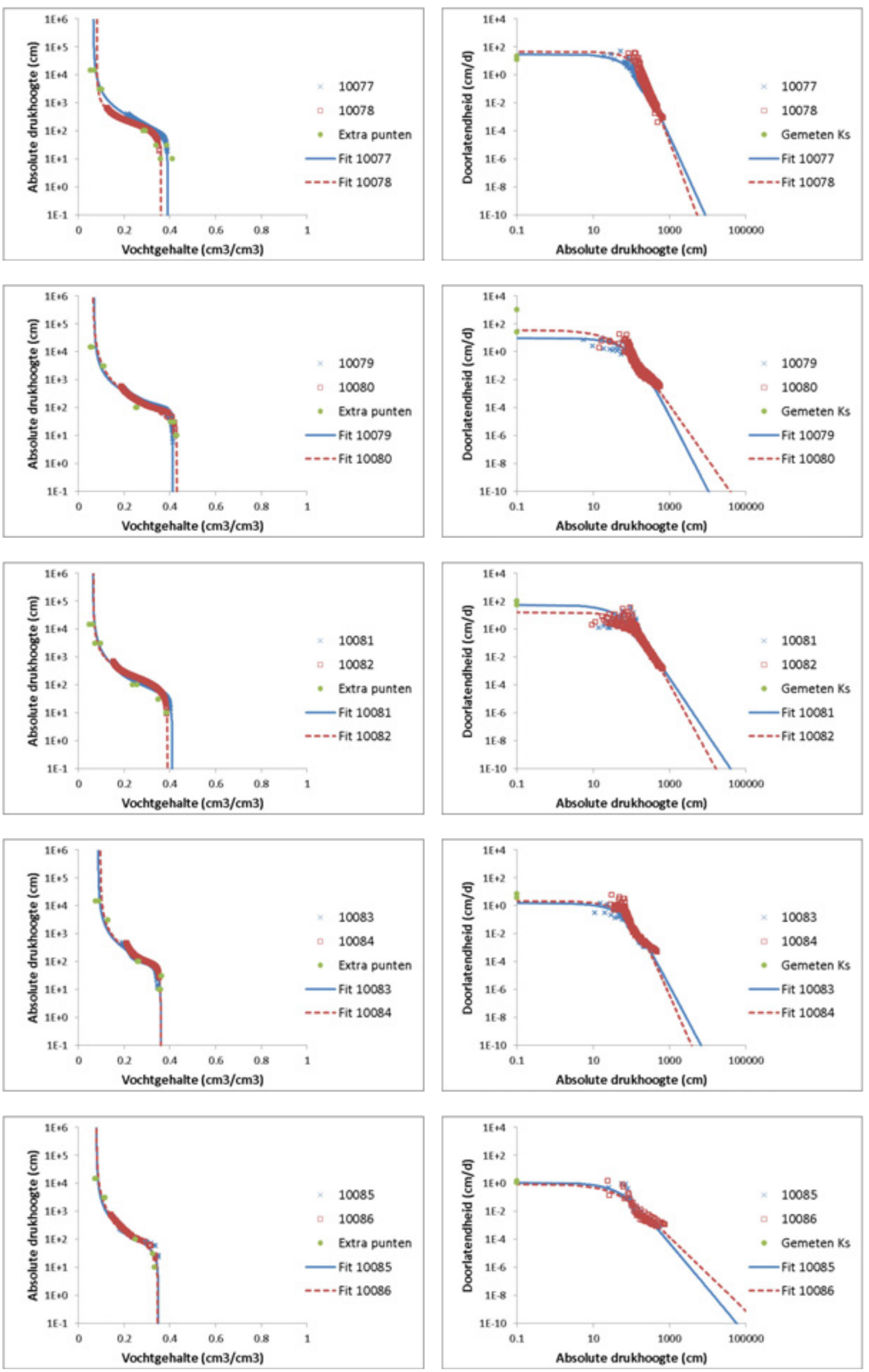

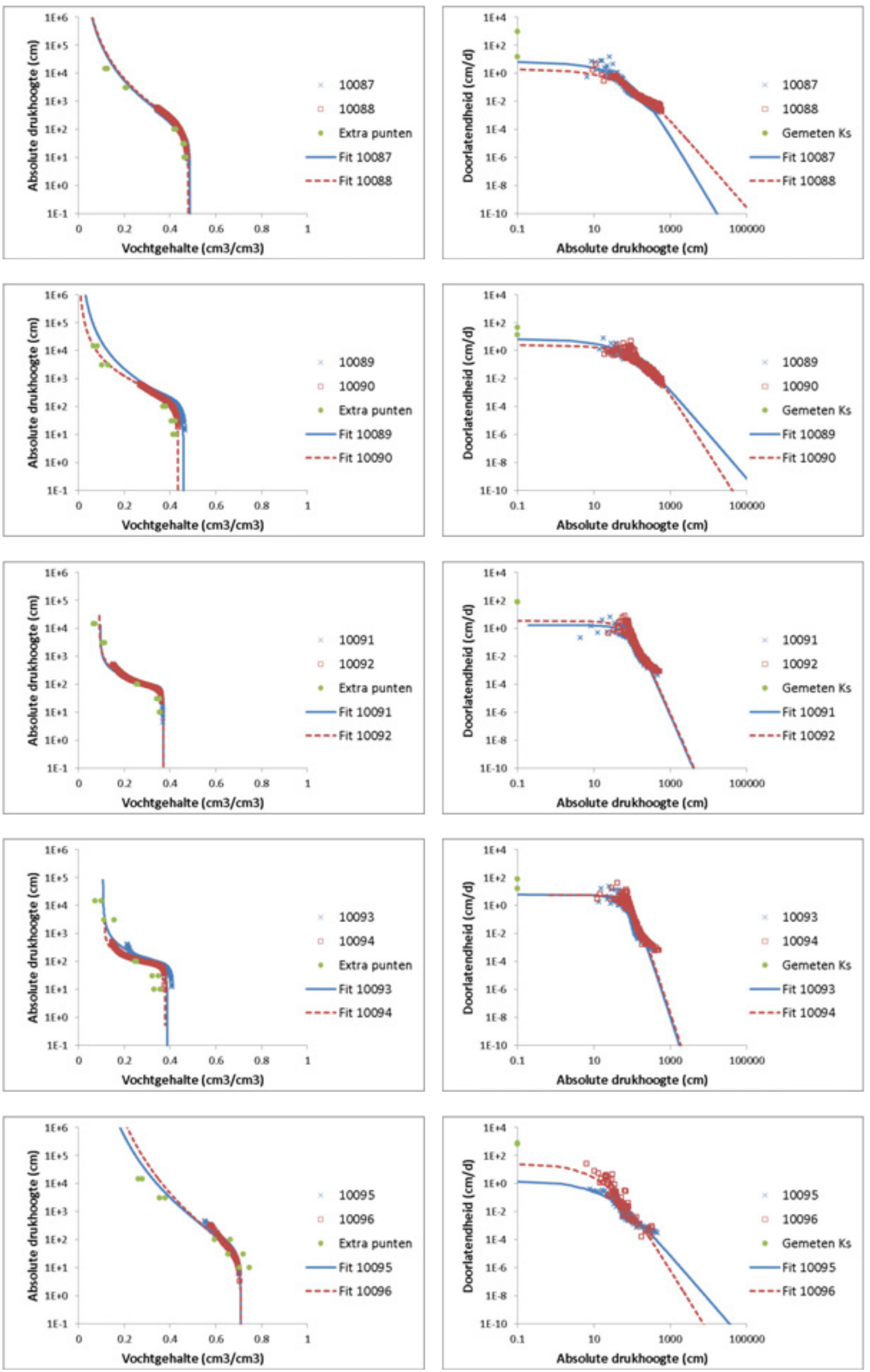

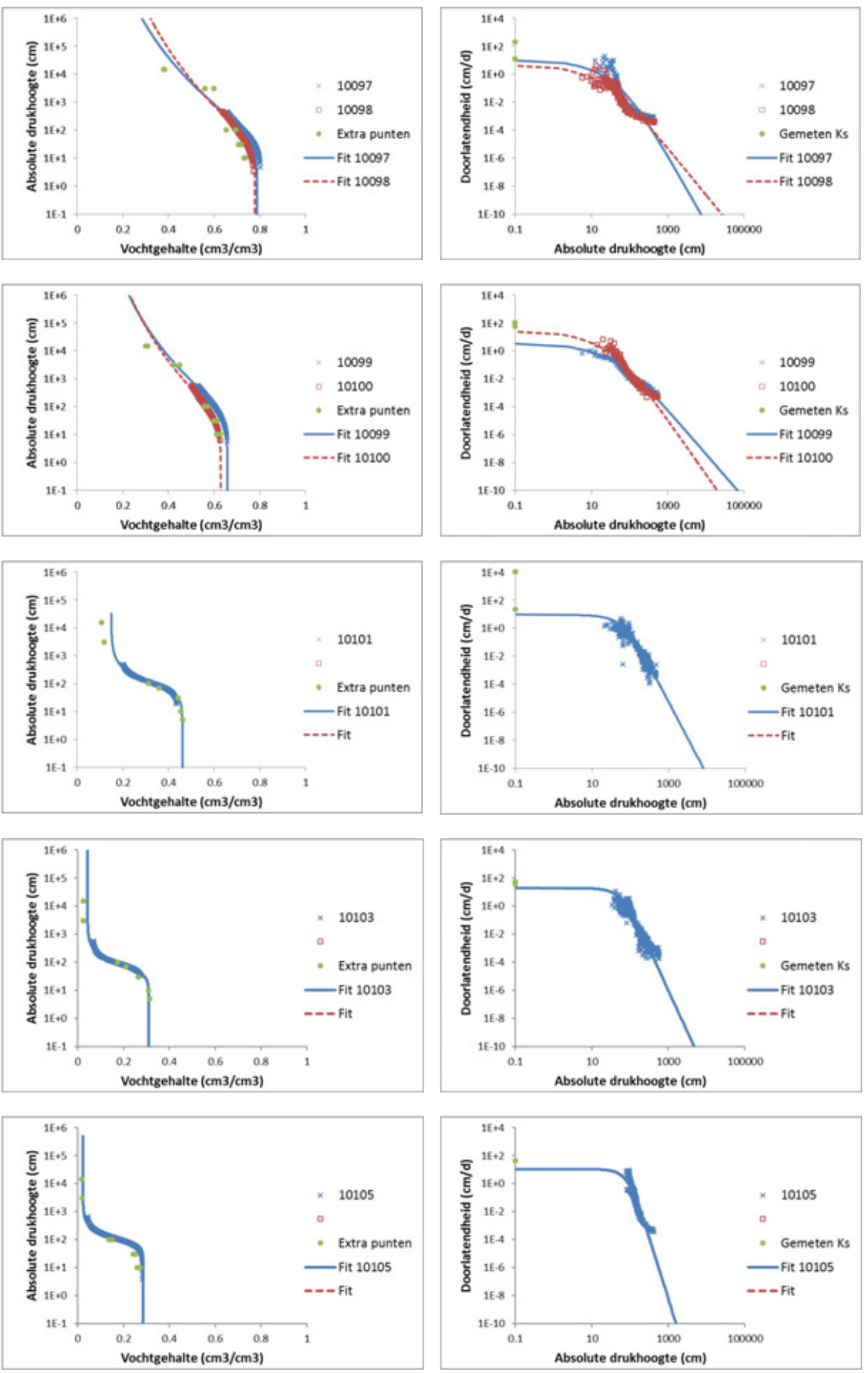

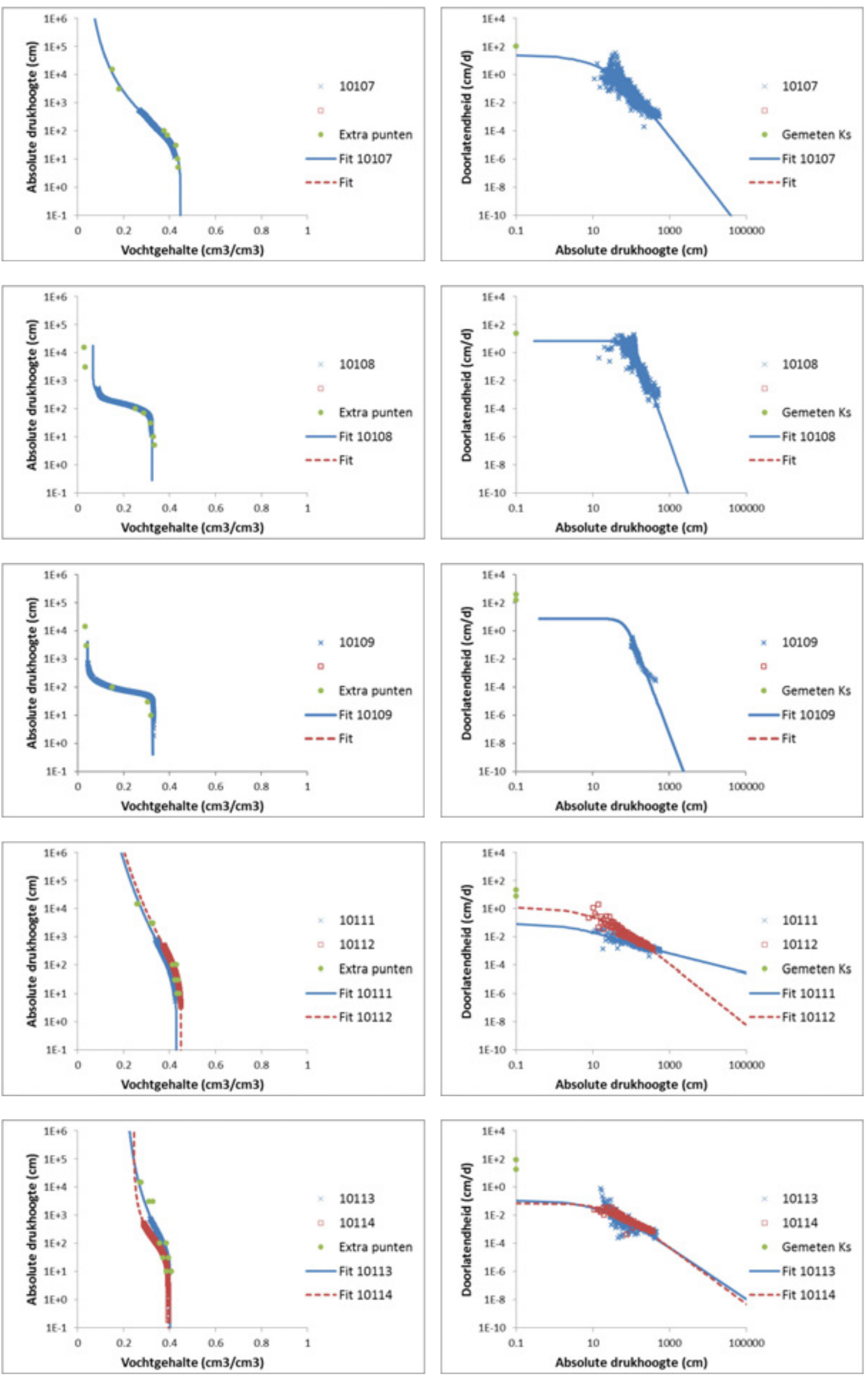

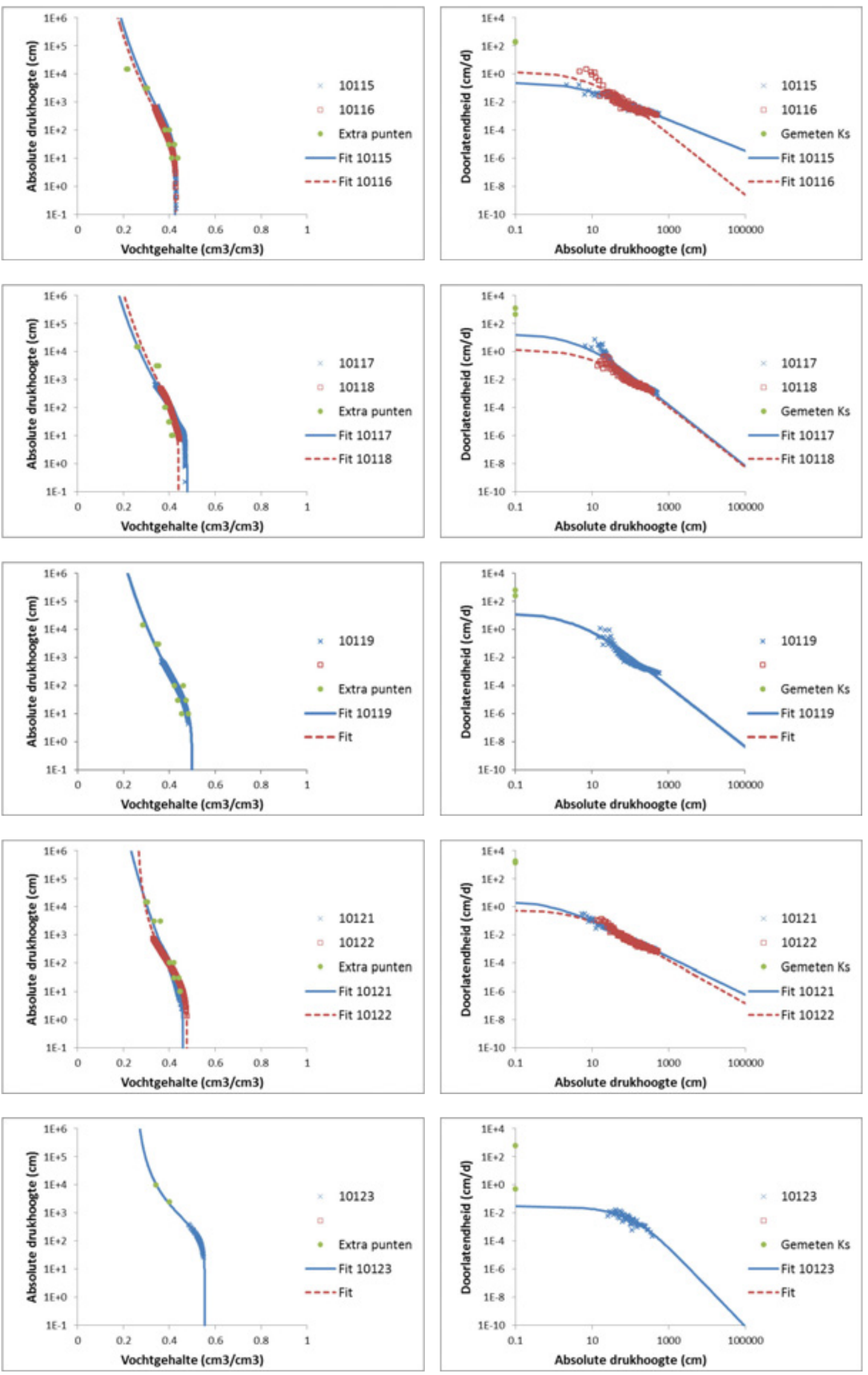

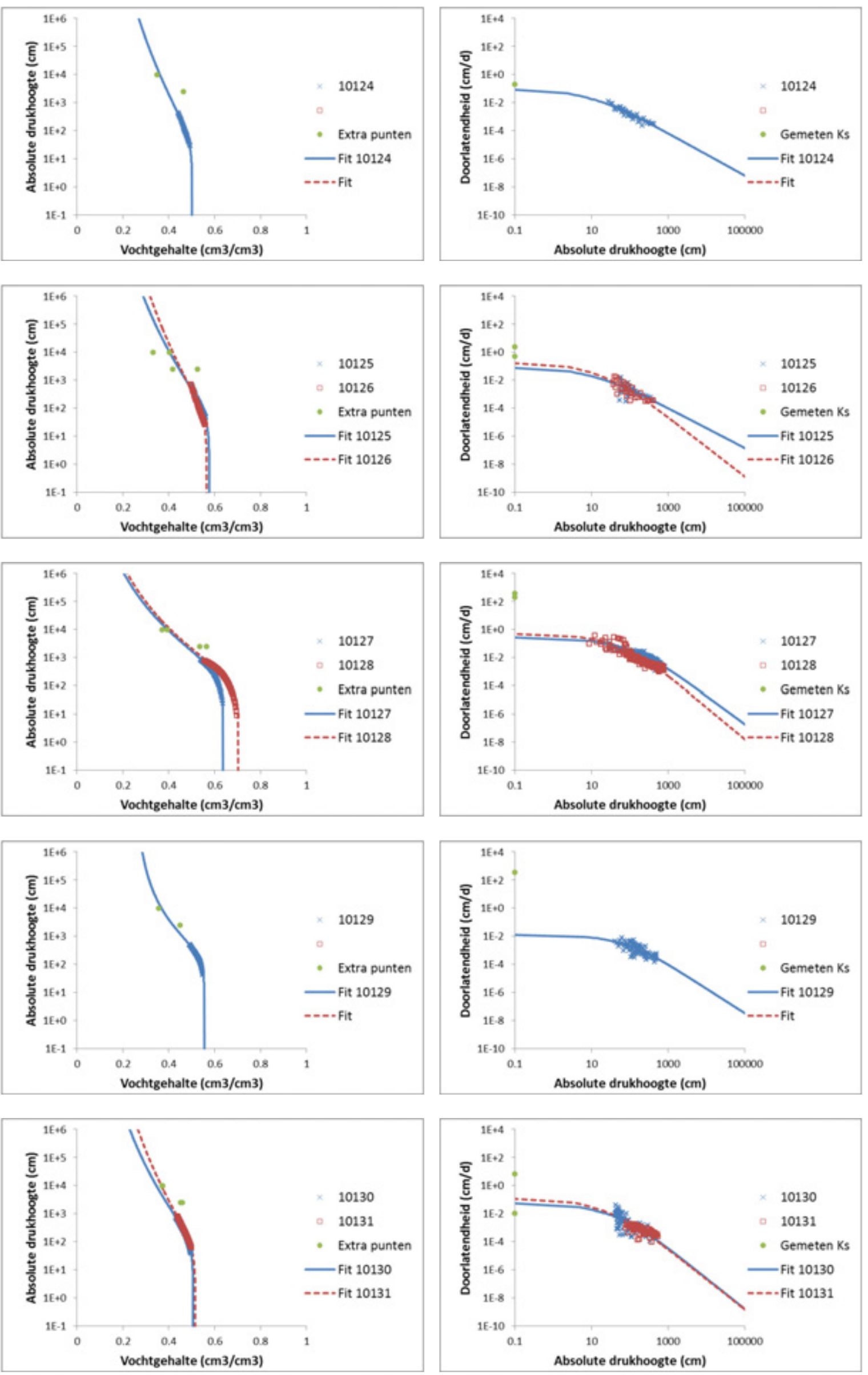

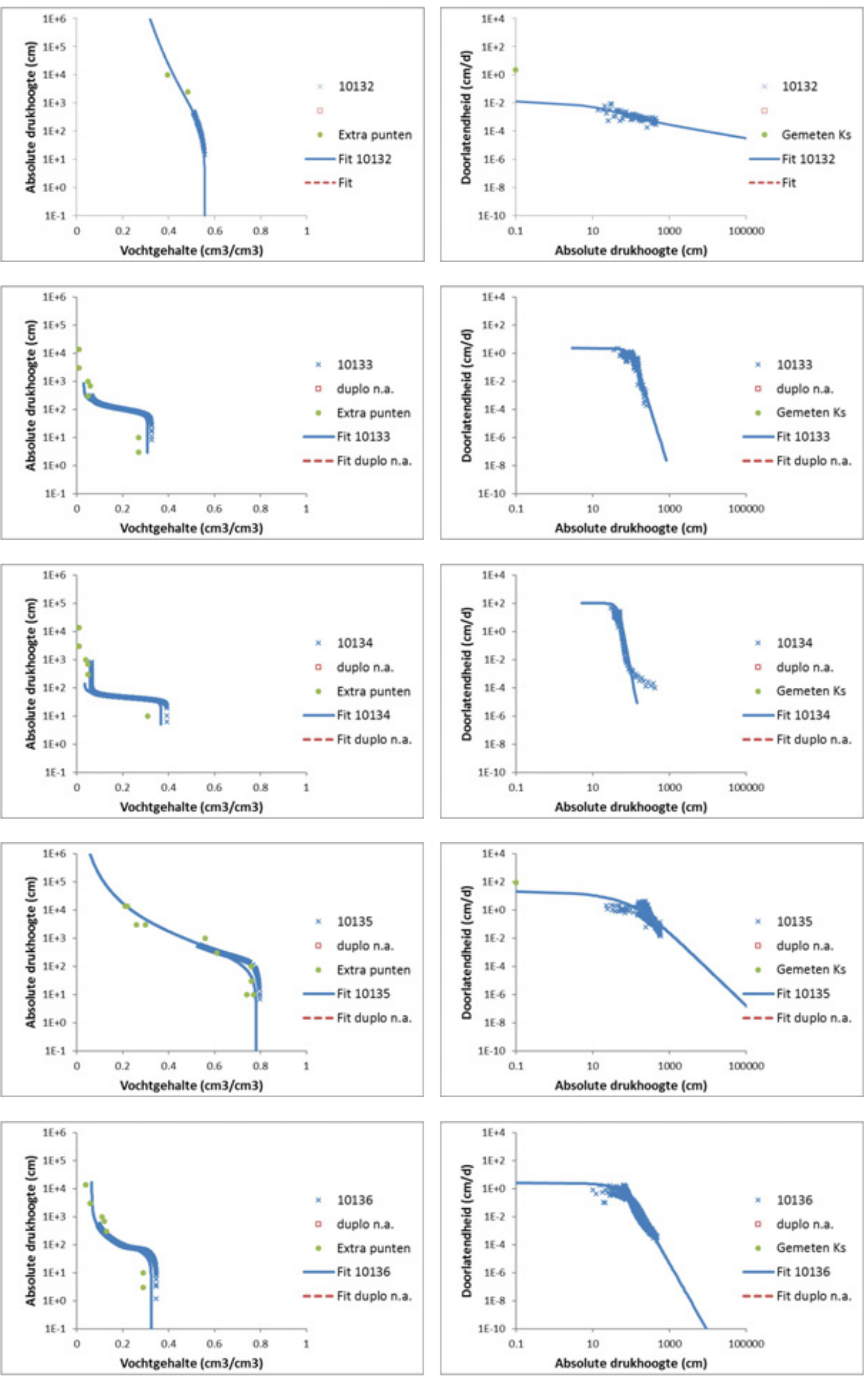

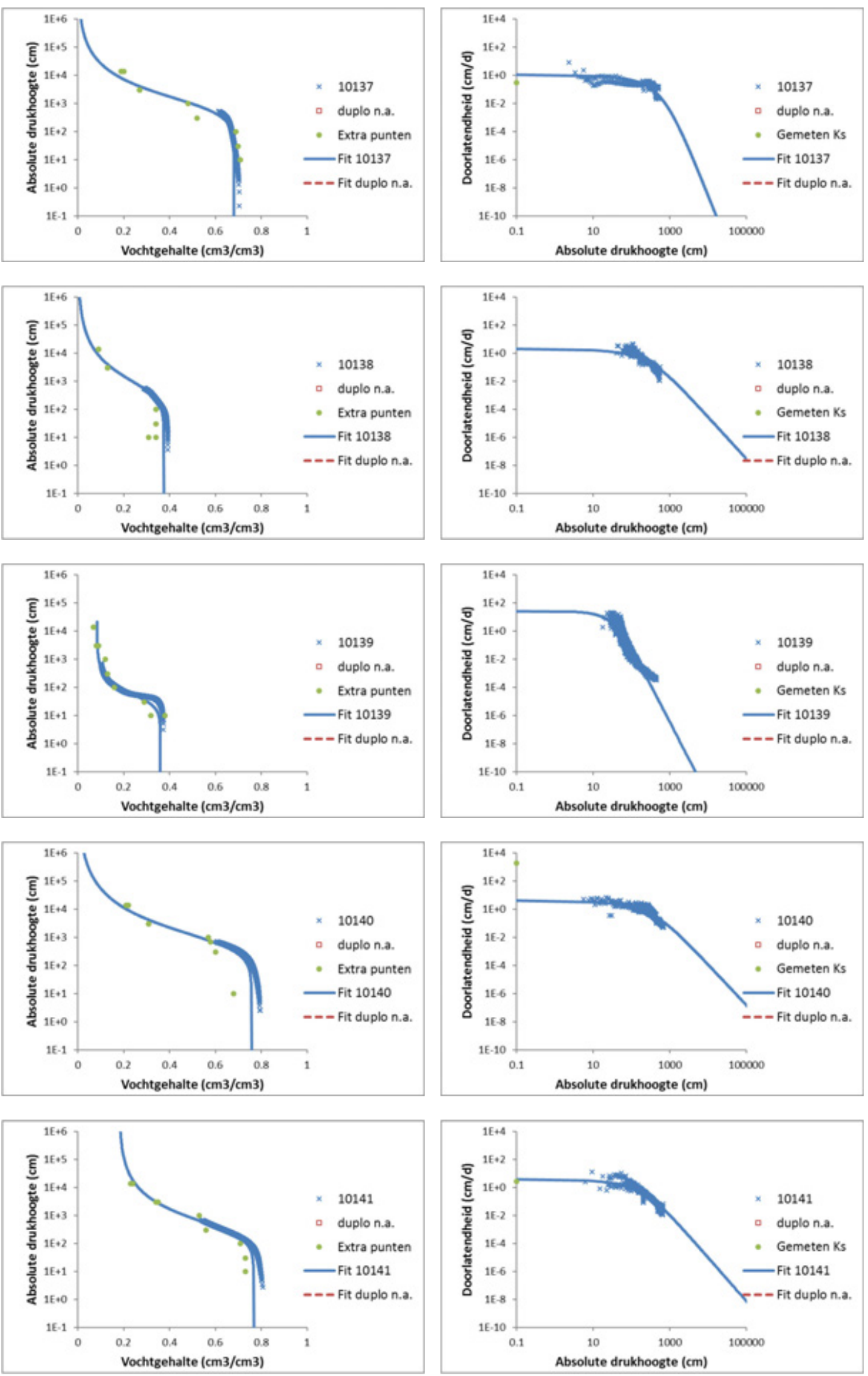

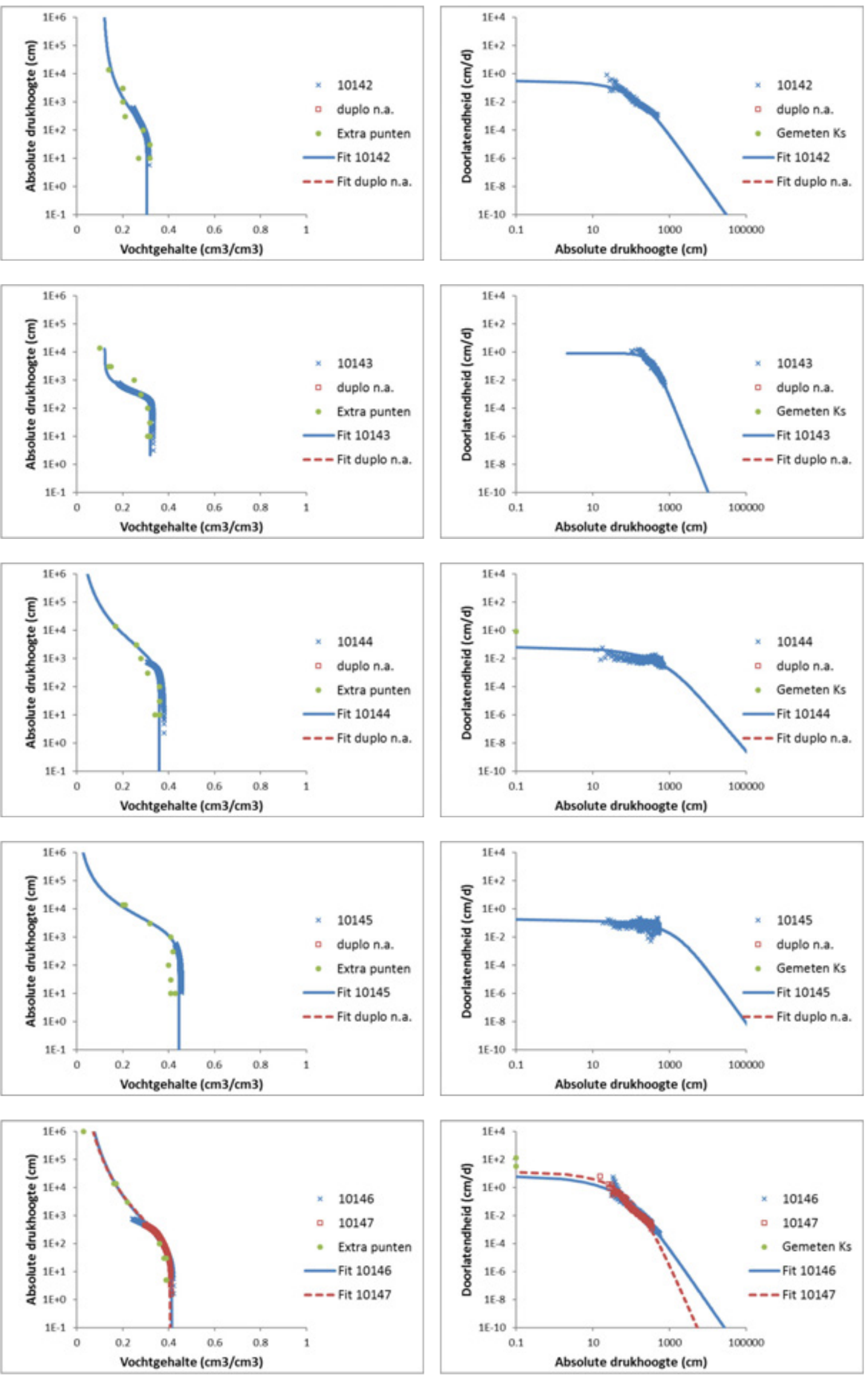

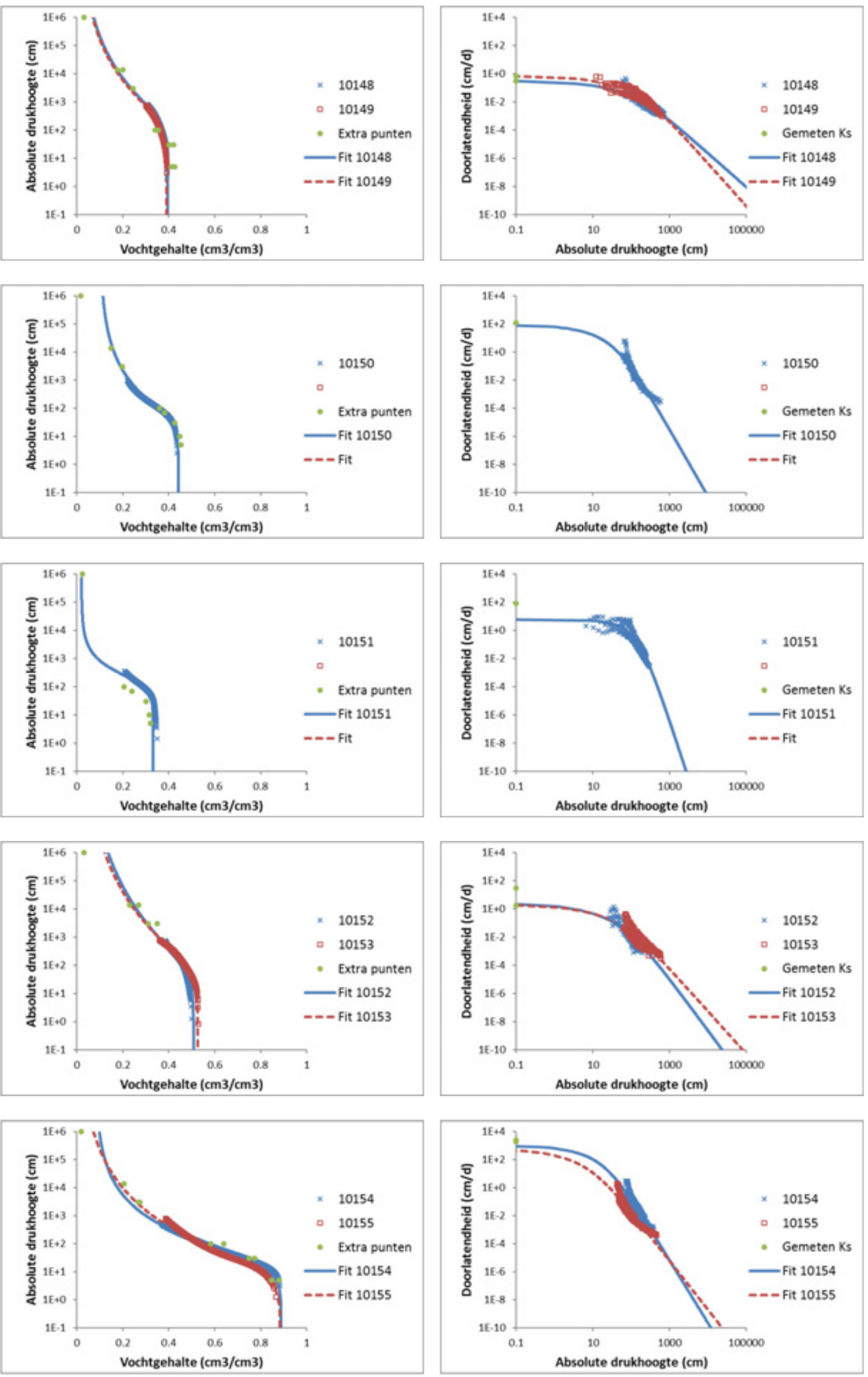


\section{Bijlage 10 Bodemkundige Karakterisering: BoKa (Geo)-codes}

In bodemkarteringen wordt het milieu waarin het materiaal is afgezet of de wijze waarop een bodemhorizont is ontwikkeld, aangeduid met een bodemkundige karakteriserings-code, hier afgekort tot BoKa-code (vroeger "Geocode"). Deze code wordt vanaf 1984 verplicht aan de onderscheiden bodemhorizonten in bodemkarteringen toegekend. De codes zijn in onderstaande tabel weergegeven.

\begin{tabular}{|c|c|}
\hline BoKa-code & Beschrijving \\
\hline 0 & Onbekend \\
\hline 100 & MOERIG MATERIAAL \\
\hline 110 & Zonder herkenbare plantenresten (bv. veraard of sterk verweerd) \\
\hline 120 & Bosveen \\
\hline 130 & Zeggeveen \\
\hline 140 & Rietveen \\
\hline 150 & Veenmosveen \\
\hline 151 & Veenmosveen; bolster \\
\hline 152 & Veenmosveen; overig \\
\hline 160 & Sedimentair veen (bv. Gyttja \\
\hline 170 & Strooisellaag \\
\hline 171 & Strooisellaag van loofhout \\
\hline 172 & Strooisellaag van naaldhout \\
\hline 190 & Overige veensoorten (bv. Scheuchzeriaveen) \\
\hline 200 & MARIENE AFZETTINGEN (holoceen) \\
\hline 210 & Getijde afzettingen; zout \\
\hline 211 & Jong (afzettingen van Duinkerke; incl. zand) \\
\hline 212 & Oud (afzettingen van Calais; incl. zand) \\
\hline 220 & Getijde afzettingen; zoet \\
\hline 230 & Mariene onderwaterafzettingen (lagunair) \\
\hline 300 & FLUVIATIELE AFZETTINGEN \\
\hline 310 & Zeer recente afzetting in uiterwaarden \\
\hline 320 & Holocene afzettingen van Rijn of Maas \\
\hline 321 & Holocene afzettingen van Rijn \\
\hline 322 & Holocene afzettingen van Maas \\
\hline 330 & Pleistocene afzettingen van Rijn of Maas \\
\hline 331 & Laat-Pleistoceen (formatie v. Kreftenheye) \\
\hline 332 & Midden- en Vroeg-Pleistoceen (niet gestuwd) \\
\hline 340 & Afzetting overige rivieren (Vecht) \\
\hline 390 & Overige fluviatiele afzettingen (bv. Form. v. Enschede) \\
\hline 400 & EOLISCHE EN FLUVIO-PERIGLACIALE AFZETTINGEN \\
\hline 410 & Dekzand \\
\hline 411 & Jong dekzand \\
\hline 412 & Oud dekzand \\
\hline 413 & Fluvio-periglaciaal \\
\hline 420 & Loss \\
\hline 421 & Loss; dekafzettingen \\
\hline 422 & Loss in lokale depressies (bv. Brabants leem) \\
\hline 430 & Kustduinzand \\
\hline 431 & Jong kustduinzand \\
\hline 432 & Oud kustduinzand \\
\hline 440 & Rivierduinzand \\
\hline 450 & Landduinzand (bv. stuifzand) \\
\hline 490 & Overige afzettingen (bv. eolisch premorenaal zand) \\
\hline
\end{tabular}




\section{GLACIALE EN FLUVIO-GLACIALE AFZETTINGEN}

$510 \quad$ Keileem

$520 \quad$ Keizand

$530 \quad$ Smeltwaterafzettingen

$531 \quad$ Smeltwaterafzetting; zand

532 Smeltwaterafzetting; (warven)klei

533 Smeltwaterafzetting; potklei

600 OVERIGE AFZETTINGEN

610 Hellingafzetting incl. puinwaaierafz. (voor droge dalen)

620 Secundaire loss (bv. colluvium)

630 Gestuwde afzettingen

631 Gestuwde afzettingen van Rijn of Maas

632 Gestuwde afzettingen van oostelijke rivieren

690 Overige

691 Overige geogene afzettingen (bv. kalksteen)

692 Antropogeen homogeen (bv. mestdek)

693 Antropogeen heterogeen (bv. zand + veen)

699 Onbekend 


\section{Bijlage 11 Indeling Staringreeks}

\begin{tabular}{|c|c|c|c|c|c|c|c|c|c|c|c|c|c|}
\hline \multirow{2}{*}{\multicolumn{2}{|c|}{ Bouwsteen }} & \multirow[b]{2}{*}{ Omschrijving } & \multirow[b]{2}{*}{ Opm } & \multicolumn{2}{|c|}{ Leem $\%$} & \multicolumn{2}{|c|}{ Lutum\% } & \multicolumn{2}{|c|}{ OS\% } & \multicolumn{2}{|c|}{ OS\% } & \multicolumn{2}{|c|}{ M50 } \\
\hline & & & & van & tot & van & tot & van & tot & van & tot & van & tot \\
\hline & & & & & & & & \multicolumn{2}{|c|}{ Bovengr. } & \multicolumn{2}{|c|}{ Ondergr. } & & \\
\hline B1 & O1 & leemarm zeer fijn zand & $\mathrm{a}$ & 0 & 10 & - & - & 0 & 15 & 0 & 3 & 105 & 210 \\
\hline B1 & O1 & leemarm matig fijn zand & - & 0 & 10 & - & - & 0 & 15 & 0 & 3 & 105 & 210 \\
\hline B2 & $\mathrm{O} 2$ & zwak lemig zeer fijn zand & $\mathrm{a}$ & 10 & 18 & - & - & 0 & 15 & 0 & 3 & 105 & 210 \\
\hline B2 & $\mathrm{O} 2$ & zwak lemig matig fijn zand & - & 10 & 18 & - & - & 0 & 15 & 0 & 3 & 105 & 210 \\
\hline B3 & $\mathrm{O} 3$ & sterk lemig zeer fijn zand & $\mathrm{a}$ & 18 & 33 & - & - & 0 & 15 & 0 & 3 & 105 & 210 \\
\hline B3 & $\mathrm{O} 3$ & sterk lemig matig fijn zand & - & 18 & 33 & - & - & 0 & 15 & 0 & 3 & 105 & 210 \\
\hline B4 & $\mathrm{O} 4$ & zeer sterk lemig zeer fijn zand & a & 33 & 50 & - & - & 0 & 15 & 0 & 3 & 105 & 210 \\
\hline B4 & $\mathrm{O} 4$ & zeer sterk lemig matig fijn zand & - & 33 & 50 & - & - & 0 & 15 & 0 & 3 & 105 & 210 \\
\hline B5 & 05 & grof zand & - & - & - & - & - & 0 & 15 & 0 & 3 & 210 & 2000 \\
\hline B6 & 06 & keileem & c & 0 & 50 & - & - & 0 & 15 & 0 & 3 & 50 & 2000 \\
\hline- & 07 & beekleem & c & 33 & 50 & - & - & 0 & 15 & 0 & 3 & 50 & 150 \\
\hline B7 & 08 & zeer lichte zavel & - & - & - & 8 & 12 & 0 & 15 & 0 & 3 & - & - \\
\hline B8 & 09 & matig lichte zavel & - & - & - & 12 & 18 & 0 & 15 & 0 & 3 & - & - \\
\hline B9 & 010 & zware zavel & - & - & - & 18 & 25 & 0 & 15 & 0 & 3 & - & - \\
\hline B10 & 011 & lichte klei & - & - & - & 25 & 35 & 0 & 15 & 0 & 3 & - & - \\
\hline B11 & 012 & matig zware klei & - & - & - & 35 & 50 & 0 & 15 & 0 & 3 & - & - \\
\hline B12 & 013 & zeer zware klei & - & - & - & 50 & 100 & 0 & 15 & 0 & 3 & - & - \\
\hline B13 & 014 & zandige leem & - & 50 & 85 & - & - & 0 & 15 & 0 & 3 & - & - \\
\hline B14 & 015 & siltige leem & - & 85 & 100 & - & - & 0 & 15 & 0 & 3 & - & - \\
\hline B15 & - & venig zand & $b$ & - & - & 0 & 8 & 15 & 25 & - & - & - & - \\
\hline B16 & - & zandig veen & $b$ & - & - & 0 & 8 & 25 & 100 & - & - & - & - \\
\hline B16 & - & veen & $\mathrm{b}$ & - & - & 0 & 8 & 25 & 100 & - & - & - & - \\
\hline $\mathrm{B} 17$ & - & venige klei & $b$ & - & - & 8 & 100 & 16 & 45 & - & - & - & - \\
\hline B18 & - & kleiig veen & $\mathrm{b}$ & - & - & 8 & 100 & 25 & 70 & - & - & - & - \\
\hline- & 016 & oligotroof veen & $\mathrm{b}$ & - & - & - & - & - & - & 35 & 100 & - & - \\
\hline- & 017 & mesotroof veen & $b$ & - & - & - & - & - & - & 35 & 100 & - & - \\
\hline- & 017 & eutroof veen & $\mathrm{b}$ & - & - & - & - & - & - & 35 & 100 & - & - \\
\hline- & 018 & moerige tussenlaag & $b / c$ & - & - & - & - & - & - & 15 & 35 & - & - \\
\hline
\end{tabular}

a 'zeer' lezen als 'zeer' en 'uiterst'

b Als een 'moerige grond' (bijv. BoKa-code 100) wordt geklassificeerd: venig zand t/m kleiig veen, zou dat leiden tot een B15:B18. Als echter in het veld bepaald is dat het niet een Bovengrond, maar Ondergrond betreft, kan overgestapt worden op een 016:018, mits de veensoort bekend is. Dit is zondermeer uitwisselbaar. Bijvoorbeeld: een venige klei (B17) kan een eutroof veen (O17) als benaming krijgen, ook al is de eerste benaming in beginsel een klei.

c Als BoKa-code $=510$, dan 'Keileem'

Als BoKa-code $=340 \mathrm{EN}$ het is een Ondergrond, dan 'Beekleem'

Als 'veen' in textuurnaam voorkomt EN ('K42' OF ' $2 \mathrm{~m}^{\prime}$ ) in Standaardpuntencode, dan 'Moerige tussenlaag' 


\section{Bijlage 12 Aantal BIS-monsters voor de 38 opschalingseenheden}

N.B.: Monsters kunnen in meerdere opschalingseenheden voorkomen.

\begin{tabular}{|c|c|c|c|c|}
\hline Eenheid & OE38-Code & Omschrijving & Aantal & Totaal \\
\hline \multirow{4}{*}{$\begin{array}{l}\text { Bodemkundige Karakterisering } \\
\text { (BoKa) }\end{array}$} & 0-199 & Moerig materiaal & 17 & \multirow[t]{4}{*}{198} \\
\hline & $200-299$ & Mariene (holocene) afzettingen & 53 & \\
\hline & $400-499$ & Eolische- en fluvio-periglaciale afzettingen & 55 & \\
\hline & $500-599$ & Glaciale en fluvio-glaciale afzettingen & 8 & \\
\hline \multirow[t]{2}{*}{ Boven- en Ondergrond } & B & Bovengrond & 89 & \multirow[t]{2}{*}{198} \\
\hline & 0 & Ondergrond & 109 & \\
\hline \multirow[t]{2}{*}{ Hoofdindeling } & MM & Moerig_Mineraal & 17 & \multirow[t]{2}{*}{198} \\
\hline & $\mathrm{E}$ & Eolisch & 74 & \\
\hline \multirow{9}{*}{ Organisch } & vK & venige klei & 1 & \multirow{9}{*}{184} \\
\hline & $\mathrm{H}$ & humusrijk & 5 & \\
\hline & $\mathrm{zH}$ & zeer humeus & 11 & \\
\hline & $\mathrm{mH}$ & matig humeus & 63 & \\
\hline & $\mathrm{mHa}$ & matig humusarm & 32 & \\
\hline & $\mathrm{zHa}$ & zeer humusarm & 28 & \\
\hline & $\mathrm{uHa}$ & uiterst humusarm & 29 & \\
\hline & $z V$ & zandig veen & 0 & \\
\hline & $v Z$ & venig zand & 1 & \\
\hline Eolisch & $s L$ & siltige leem & 5 & 82 \\
\hline \multirow[t]{10}{*}{ Niet-eolisch } & kaZ & kleiarm zand & 18 & \multirow[t]{10}{*}{106} \\
\hline & kaS & kleiarm silt & 1 & \\
\hline & $\mathrm{kZ}$ & kleiig zand & 11 & \\
\hline & $\mathrm{kS}$ & kleiig silt & 0 & \\
\hline & $z \mid z$ & zeer lichte zavel & 5 & \\
\hline & $\mathrm{mlz}$ & matig lichte zavel & 13 & \\
\hline & $z Z$ & zware zavel & 14 & \\
\hline & IK & lichte klei & 21 & \\
\hline & $\mathrm{mzK}$ & matig zware klei & 9 & \\
\hline & zzK & zeer zware klei & 14 & \\
\hline
\end{tabular}


Wageningen Environmental Research Postbus 47

6700 AA Wageningen

T 0317480700

www.wur.nl/environmental-research

Wageningen Environmental Research Rapport 2895

ISSN 1566-7197
De missie van Wageningen University \& Research is 'To explore the potential of nature to improve the quality of life'. Binnen Wageningen University \& Research bundelen Wageningen University en gespecialiseerde onderzoeksinstituten van Stichting Wageningen Research hun krachten om bij te dragen aan de oplossing van belangrijke vragen in het domein van gezonde voeding en leefomgeving. Met ongeveer 30 vestigingen, 5.000 medewerkers en 10.000 studenten behoort Wageningen University \& Research wereldwijd tot de aansprekende kennisinstellingen binnen haar domein. De integrale benadering van de vraagstukken en de samenwerking tussen verschillende disciplines vormen het hart van de unieke Wageningen aanpak. 



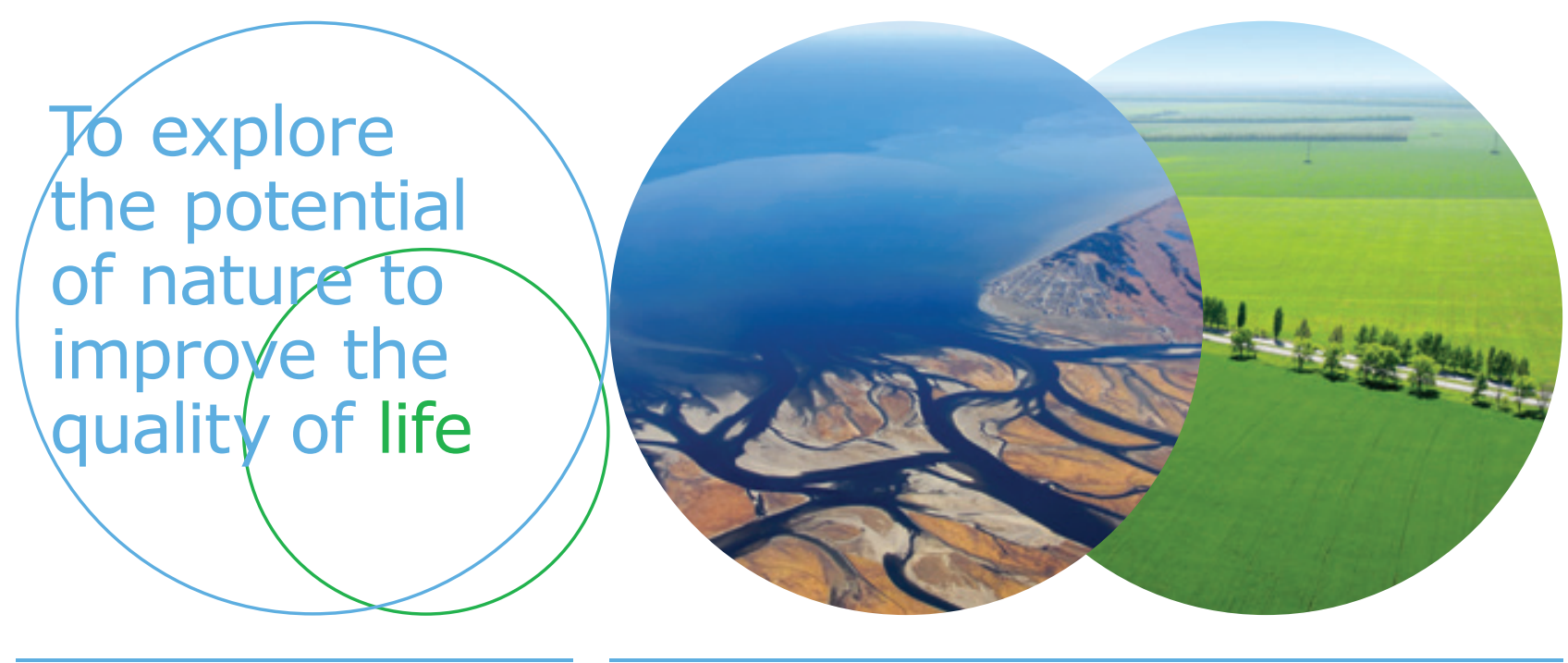

Wageningen Environmental Research Postbus 47

$6700 \mathrm{AB}$ Wageningen

T 317480700

www.wur.nl/environmental-research

Rapport 2895

ISSN 1566-7197
De missie van Wageningen University \& Research is 'To explore the potential of nature to improve the quality of life'. Binnen Wageningen University \& Research bundelen Wageningen University en gespecialiseerde onderzoeksinstituten van Stichting Wageningen Research hun krachten om bij te dragen aan de oplossing van belangrijke vragen in het domein van gezonde voeding en leefomgeving. Met ongeveer 30 vestigingen, 5.000 medewerkers en 10.000 studenten behoort Wageningen University \& Research wereldwijd tot de aansprekende kennisinstellingen binnen haar domein. De integrale benadering van de vraagstukken en de samenwerking tussen verschillende disciplines vormen het hart van de unieke Wageningen aanpak. 